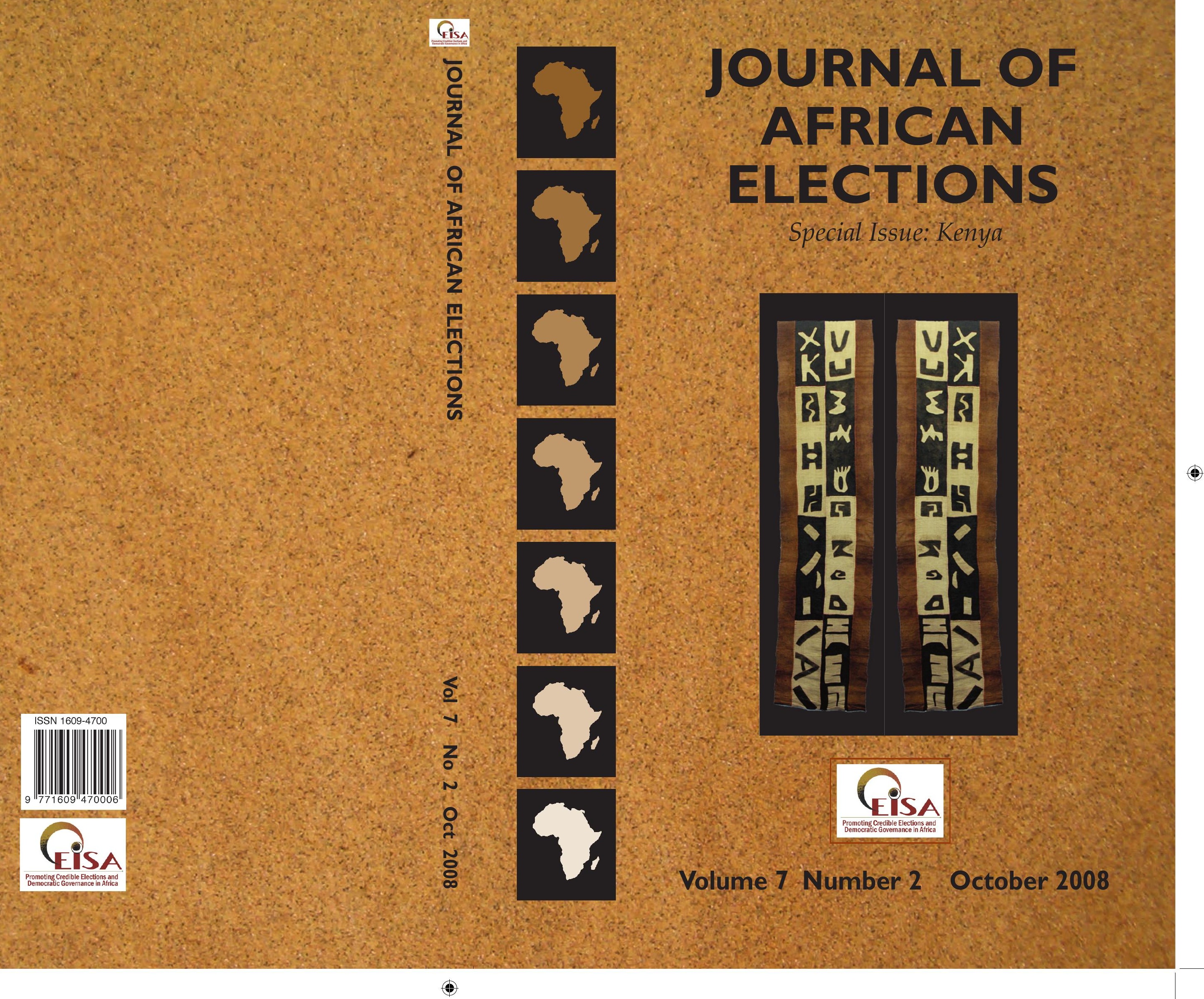




\section{Journal \\ of African Elections \\ Special Issue: Kenya}

GUEST EdITOR

Gilbert M Khadiagala

Articles By

Gilbert M Khadiagala

Rok Ajulu

Korwa G Adar

Shilaho Westen Kwatemba

Felix Odhiambo Owuor

Frederick Ogenga

Samuel Kariuki 
Published by EISA

14 Park Road, Richmond

Johannesburg

South Africa

P O Box 740

Auckland Park

2006

South Africa

Tel: +27011 4825495

Fax: +27011 4826163

e-mail: publications@eisa.org.za

CEISA 2008

ISSN: $1609-4700$

All rights reserved. No part of this publication may be reproduced, stored in a retrieval system or transmitted in any form or by any means, electronic, mechanical, photocopying, recording or otherwise, without the written permission of the publisher

Copy editor: Pat Tucker

Printed by: Global Print, Johannesburg

Cover photograph: Reproduced with the permission of the

HAMILL GALLERY OF AFRICAN ART, BOSTON, MA, USA

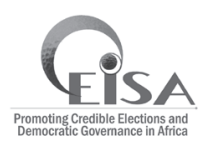

www.eisa.org.za 
Denis Kadima, Electoral Institute of Southern Africa, Johannesburg

Khabele Matlosa, Electoral Institute of Southern Africa, Johannesburg

\section{EDITORIAL BOARD}

Tessy Bakary, Office of the Prime Minister, Abidjan, Côte d'Ivoire David Caroll, Democracy Program, The Carter Center, Atlanta Jørgen Elklit, Department of Political Science, University of Aarhus, Denmark Amanda Gouws, Department of Political Science, University of Stellenbosch Abdalla Hamdok, International Institute for Democracy Assistance, Pretoria Sean Jacobs, New York University, Brooklyn, NY Claude Kabemba, Southern Africa Resource Watch, Johannesburg Peter Kagwanja, International Crisis Group, Southern Africa Project, Pretoria Peter Katjavivi, Ambassador of Namibia to Berlin Abdul Rahman Lamin, Department of International Relations, University of the Witwatersrand, Johannesburg

Tom Lodge, Department Politics and Public Administration, University of Limerick

Robin Ludwig, UN Dialogue with the Global South, New York

Robert Mattes, Department of Political Science, University of Cape Town

Yvonne Muthien, Corporate Affairs, MTN South Africa

Eghosa Osaghae, Igbinedion University, Okada, Nigeria

David Pottie, The Carter Center, Atlanta

Ben Reilly, Director, Centre for Democratic Institutions, The Australian National University, Canberra

Lloyd Sachikonye, Institute of Development Studies, University of Zimbabwe, Harare Jeremy Seekings, Sociology Department, University of Cape Town

Timothy Sisk, Graduate School of International Studies, University of Denver, Colorado

Gloria Somolekae, Programme Director, W K Kellogg Foundation, Pretoria and EISA

Board member

Roger Southall, Human Sciences Research Council, Pretoria

The Journal of African Elections is an interdisciplinary biannual publication of research and writing in the human sciences, which seeks to promote a scholarly understanding of developments and change in Africa. Responsibility for opinions expressed and for the accuracy of facts published in papers, research notes, review articles and book reviews rests solely with the individual authors or reviewers. Contributions are referred to specialist readers for consideration, but the Editor is responsible for the final selection of the contents of the Journal.

Editorial correspondence, including manuscripts for submission and books for review, should be sent to:

The Editor, Journal of African Elections

EISA: P O Box 740

Auckland Park 2006, South Africa

Business correspondence, including orders and remittances, subscription queries, advertisements, back numbers and offprints, should be addressed to:

The Publisher, Journal of African Elections

EISA: P O Box 740

Auckland Park 2006 South Africa 


\section{CONTENTS}

Editorial

Gilbert M Khadiagala.

1

Forty Days and Nights of Peacemaking in Kenya

Gilbert M Khadiagala.....

4

Kenya's 2007 Elections: Derailing Democracy Through Ethno-Regional Violence

Rok Ajulu

The Legal Framework of the GNU and the Doctrine of the Separation of Powers:

Implications for Kenya's National Legislative Assembly

Korwa G Adar

Ethnicity and Political Pluralism in Kenya

Shilaho Westen Kwatemba

The 2007 General Elections in Kenya: Electoral Laws and Process

Felix Odhiambo Owuor....

The Role of the Kenyan Media in the 2007 Elections

Fredrick Ogenga

'We've been to hell and back ...': Can a Botched Land Reform Programme

Explain Kenya's Political Crisis? (1963-2008)

Samuel Kariuki.

Review

Contents of Previous Issues 188

Notes for Contributors 


\section{EDITORIAL}

\section{Gilbert M Khadiagala}

This special issue of the Journal of African Elections emanated from a conference on 'Conflict Resolution in Kenya' held at the University of the Witwatersrand in August 2008 at which lecturers and post-graduate students from the Faculty of Humanities reflected on the momentous process of change in Kenya.

While most of the papers dealt with a wide array of questions relating to the causes, course and consequences of the conflict in Kenya after the December 2007 elections, the papers included in this issue speak directly to the politico-economic dimension of the crisis, analysing it from the perspective of democratisation trends in Africa and pointing out the opportunities and challenges of building stable systems of political contestation.

The Kenyan conflict is not unique, it is a quintessential African story in which the democratisation glass is glaringly both half full and half empty.

What is, perhaps, unique to Kenya is the apparent political normality which concealed profound questions of ethnicity, class, and social malaise 45 years after decolonisation and 15 years after the advent of multiparty democracy. This situation is partly attributable to the exceptionalism that has often characterised Kenya's position in East Africa: a relative period of stability and social amity; a vibrant middle class anchored in both industry and agriculture; a cosmopolitan civil society; and contentious media.

As neighbouring countries confronted social turmoil and political decay ruling elites in Kenya exploited this exceptionalism to their advantage, using it to sustain a semblance of nationhood which was clothed in political authoritarianism. It was not until the stirrings of change of the late 1990s that most Kenyans awoke from the slumber of regional uniqueness to realise that they faced challenges similar to those faced by their neighbours. Beneath the veneer of stability and civility was the decimation of social and political institutions, the transformation of the national economy into a privatised realm of fiefs and corrupt cartels, a resurgence of the violent mobilisation of ethnic differences, and the socioeconomic marginalisation of large segments of society.

Multiparty democracy exacerbated the multiple sources of insecurity present in the body politic. Thus, as the regime of Daniel arap Moi sluggishly and reluctantly opened up the spaces of pluralism it confronted a society that was deeply divided. 
As in most of Africa democratisation promised political renewal, but the social base for building pluralism was inchoate and brittle. For this reason there was multiparty competition without significant liberalisation of society, while elections were conducted merely to renew the mandate of authoritarian leaders and ward off the prying eyes of Western donors.

Aggravating problems in the first phase of the democratisation era (in the mid-1990s) was the deliberate attempt by the Moi government to militarise society along ethnic lines. The unleashing of ethnic militias against communities that voted for opposition parties became widespread as Moi clung desperately to power.

Equally vital, electoral despotism, which paraded as democratisation, coincided with state control of all levers of power, denying opposition parties the space to mount respectable and credible challenges to the governing elites. Civil society organisations, led primarily by the middle classes, operated on the margins of politics, building new constituencies and contesting new claims, but without the latitude to make much of a difference.

Yet, by the late 1990s Kenyans also demonstrated the power of patience and persistence inherent in political parties and civic organisations. Instead of lapsing into defeatism and despair opposition forces worked creatively to push the political envelope, nurturing new alliances and devising tactics to fight the battle against electoral despotism.

The major breakthrough came during the 2002 elections, when a multi-ethnic alliance ended Moi's rule. But the shift was barely reflected in institutional and behavioural change: instead, old patterns and practices prevailed. The executive continued to resist meaningful democratisation of state institutions, in the name of order and ethnicity. Parliament, the epitome of representative government, remained an elite club of overpaid and underworked legislators. Major actors within the once-vibrant civil society gave themselves over to the comfort of government and vehemently defended the erosion of media freedoms and the onslaught on other independent institutions.

The reversal of democratic gains predictably created new forces and movements, which converged during the December 2007 elections and the subsequent violence, which the contributors to this issue have attempted to address.

Most of the articles seek to place the roots of these events in the post-colonial contest over resources, identity, and dignity. This tripartite structure of grievances is at the heart of Kenya's political economy and informs current debates about institutional change and continuity.

Although the country has been rescued from failure by the meticulous superintendence of the African Union and the international community dark clouds still hover on Kenya's political landscape: stark socioeconomic inequities, 
the marginalisation of restless and combustible youths, disengaged elites and leaders, cancerous corruption at all levels of society, and weak institutions.

More worrying is the structure of institutions produced by the compromises negotiated after the post-election violence. Although the establishment of the grand coalition government gave the country the opportunity to find its feet again the new system has the potential to cause paralysis.

Ten months into the grand coalition debilitating differences have emerged over the power-sharing arrangement between president and prime minister, which may, in the long run, impede decision-making. In addition, although there is still a national consensus about the need for constitutional reform the coalition arrangements may lull the previously feuding elites into complacency, postponing the fundamental changes which would establish sturdy rules for posterity.

As the 2012 elections approach Kenya's leaders face a dilemma over whether to create a new constitution that will protect the country from a repetition of the problems that followed the 2007 elections or whether to procrastinate on reform in the hope that the future will take care of itself.

Kenya's emergence from its regional exceptionalism to take its place as a normal African country holds lessons for the rest of Africa. Although elections and democratisation may generate conflicts these conflicts are often a reflection of broad societal fissures and fault-lines that need to be held in check by predictable institutional rules. Weak participation, accountability, and transparency in Africa are the result of the failure of leaders to entrench these rules not of the innate inability of African societies to domesticate and embrace the norms and values that underpin them. 


\title{
FORTY DAYS AND NIGHTS OF PEACEMAKING IN KENYA
}

\section{Gilbert M Khadiagala}

Gilbert Khadiagala is Jan Smuts Professor of International Relations,

University of the Witwatersrand, Johannesburg

e-mail: Gilbert.Khadiagala@wits.ac.za

We are ready to go the extra mile to achieve peace. Today, we take the first step. My party and I are ready for this long journey to restore peace in our land ...We urge our people to be patient as parties work day and night to ensure that negotiations do not last a day longer than necessary.

Raila Odinga, leader of the Orange Democratic Movement (East African Standard 25 January) ${ }^{1}$

Kenya is a vital country in this region and the international community is not ready to watch it slump into anarchy.

Norwegian Ambassador Hellen Jacobsen

(East African Standard 15 February)

I will stay as long as it takes to get the issue of a political settlement to an irreversible point. I will not be frustrated or provoked to leave. It is in the interest of the men and women of Kenya, the region, Africa and the international community to have a new government.

Former UN Secretary-General Kofi Annan

(Daily Nation 16 February)

\begin{abstract}
Recent studies on resolving civil conflicts have focused on the role of external actors in husbanding durable agreements. The contribution of authoritative parties is vital to the mediation of conflicts where parties are frequently
\end{abstract}

1 In the interests of avoiding repetition citations will carry the date and month only unless the year is anything other than 2008. 
too divided and where the stakes are too high to allow bilateral solutions. ${ }^{2}$ In the wide-ranging conflicts that convulsed Africa throughout the 1990s mediators helped the combatants to reach ceasefires and find constitutional structures that restored a modicum of stability and civility to tattered polities. More recently, electoral conflicts in Africa have emerged as new sites of external intervention, attracting multilateral and regional actors. The much-publicised cases of Kenya and Zimbabwe are instructive in this regard and constitute interesting areas of research into how external parties have tried to influence the trajectories of coalition governments.

This paper reviews the peacemaking process in Kenya after the contested and violent outcome of the December 2007 elections. After a series of false starts in early January the mediation process stabilised around an African Union (AU) Panel of Eminent African Personalities, comprising former United Nations Secretary-General Kofi Annan, former Tanzanian President Benjamin Mkapa, and Mozambican luminary Graça Machel. In about 40 days the panel steered the parties toward a power-sharing agreement that was signed on 28 February 2008. In tracing this process I am interested in the issues, the personalities who animated the negotiations, and how the mediators (alongside other external actors) produced the power-sharing outcome. The analysis begins with a background to the conflict, furnishing brief insights into the questions that sparked the violence. This is followed by discussion of the various people who attempted to mediate the conflicts before the emergence of the panel. Subsequent sections address how the mediators engaged the parties and the process of reaching the agreement. The paper concludes with a brief discussion of the role of mediators and lessons for other conflicts.

\section{BACKGROUND}

The elections of 27 December 2007 were the fourth electoral exercise in Kenya since the inauguration of the multiparty era in the early 1990s. They were momentous because of the large voter turnout, reflecting a yearning to achieve a better future through the ballot box.

They also symbolised a learning process through which, after three elections of varying competitiveness and openness, the electorate had begun to be acclimatised to the perception that it could make a decisive difference through the vote, whether in local, parliamentary, or presidential elections.

2 For a summary of some of these studies see Maundi 2006 and Khadiagala 2007. 
In previous years multiple efforts by civic organisations had endowed Kenyans with an adroit sense of agitation and education that resulted in the electoral triumph of 2002, when the National Rainbow Coalition (NARC) managed to mobilise across ethnic and class lines to put an end to the sloth and decay the government of Daniel arap Moi had visited on the nation for 24 years. Civic education began to create an engaged and informed citizenry that stood firm when the elected government of Mwai Kibaki procrastinated about instituting genuine constitutional reforms and lapsed into corruption and ethnic provincialism. In the 2005 constitutional referendum the government was soundly defeated when it supported a constitutional draft that fell short of national expectations. ${ }^{3}$

After the constitutional referendum disenchanted members of NARC who had fallen out with the Kibaki government formed the Orange Democratic Movement (ODM), a multi-ethnic alliance of mainly the Luo, Luhya, Kalenjin, and Coastal groups under the leadership of Raila Odinga. Remnants of NARC and a collection of other parties constituted under the Party of National Unity (PNU), led by Kibaki, drew support among the majority Kikuyu and their ethnic allies in Central Kenya.

An ODM splinter group, ODM-Kenya, led by Kalonzo Musyoka, was exclusively composed of the Kamba ethnic group. Although these tripartite blocks seemed to present a picture of ethnic polarisation in reality they dovetailed more or less with the ethnic balance of forces across the country. Given the history of ethnic mobilisation political parties in the multiparty era tried to forge alliances with some semblance of a national outlook, even though their primary organisational base remained solidly ethnic and regional.

Since the successful multi-ethnic alliance that had produced the NARC victory in 2002 the major challenge facing Kenya was whether such alliances would translate into predictable and principled organisations or whether they would remain momentary instruments for electoral contestations. The latter proved to be the case when, barely a year into the Kibaki administration, the NARC alliance unravelled and elites retreated back into ethnic cocoons.

In addition to the salience of ethnicity, the lead-up to the December 2007 elections was characterised by profound disenchantment with the Kibaki administration. With the government's defeat in the constitutional referendum the ODM coalesced around a reform agenda of constitutional change, anti-corruption, and anti-cronyism. Rightly or wrongly, the Kibaki administration was perceived throughout the campaign period as the major impediment to constitutional reforms that would decentralise power away from the imperial presidency.

3 For analyses of the 2007 and previous elections see Branch \& Cheeseman January 2009; Barkan 2004; Khadiagala 2008. 
On the other hand, the ODM was successful in galvanising the masses around a renewed sense of expeditious constitutional change. Similarly, the opposition campaigned vigorously against corruption, pointing to the multiple corruption scandals that had emerged on Kibaki's watch. All these grievances were attributed to the fact that Kibaki had surrounded himself with cronies from Central Kenya (Economist 10 January).

The high voter turnout, the PNU's loss of major parliamentary seats, and the defeat of half the members of President Kibaki's Cabinet all seemed to indicate a decisive win by the ODM. In the parliamentary contest the ODM won 99 of 210 seats against the PNU's 43. But the triumphant mood soon dissipated with the inordinate delays in the announcement of the results of the presidential vote in many constituencies.

Between 28 and 30 December the final tabulation of presidential votes from constituencies descended into chaos as the Electoral Commission of Kenya (ECK) sought to allay fears of massive rigging in favour of Kibaki. The ECK's credibility was dented when its chairman, Samuel Kivuitu, admitted in the course of the counting that some key constituencies had doctored the presidential results. At the end of a politically charged waiting period and behind closed doors the ECK hastily named Kibaki the winner after the media and observers had been hounded from the counting centre.

Kivuitu announced that Kibaki had won 4584721 and Raila 4352993 votes. On the evening of 30 December 2007 Kibaki was sworn in at a private ceremony at State House. Subsequently, Kivuitu stated that the PNU and ODM-K had forced him to announce the results, even though there had been irregularities in the tallying. ${ }^{4}$

The internecine post-election violence that left 1300 dead and 350000 internally displaced persons (IDPs) was an outcome of the bungled election, reflecting widespread anger at the ECK's abdication of its role as a neutral arbiter of political contests. Political analysts identified three forms of violence that mutated and intensified as the conflict evolved. The first was countrywide disorganised, spontaneous protests at the announcement of the result. The second was organised militia activity, starting in the Rift Valley and gradually spreading to Central Province. In the Rift Valley militia activity, carried out mainly by the Kalenjin ethnic group against the Kikuyu, took the form of killings, destruction of property, and displacement of people.

In response, long-standing militia organisations such as the Mungiki (predominantly a Kikuyu militia with roots in the Rift Valley and Central

4 The Independent Review Commission (IREC) appointed after the conclusion of the mediation and headed by retired South African Constitutional Court judge Johann Kriegler heaped blame on the ECK and recommended that it be disbanded. 
Province) re-emerged to exact revenge on ODM supporters in these regions and Nairobi's slums. The third form of violence was the excessive use of force by the government's security forces in attempts to contain the initial spontaneous protests, largely in Nyanza Province, where most of the extra-judicial killings occurred. ${ }^{5}$ This is the combustible environment which the external mediators entered to try to pull the country from the brink of disaster.

\section{THE SEARCH FOR A MEDIATOR: 2-10 JANUARY 2008}

Studies of mediation in civil conflicts devote attention to the structural factors that compel outsiders to become participants in conflict resolution by probing the role of stalemates in forcing parties to accept outside mediation. From this perspective effective mediators are often driven by the desire to redress almost impossible situations in which combatants are incapable of finding solutions on their own.

Informed by both altruistic and pragmatic motives mediators seek to break the stalemate and to move the parties from unilateral to multilateral solutions. ${ }^{6}$ Like all civil conflicts the post-electoral violence that afflicted Kenya epitomised the inability of combatants to craft local solutions.

Locked in zero-sum mentalities the PNU and ODM faced a grinding stalemate that was exacerbated by the escalating violence. With the parties short of concrete ideas about how to extricate themselves the door was opened for external mediators.

Deepening the stalemate was the attempt by both parties to lay claims to legitimacy: the PNU claimed from the outset that it had won the election while the ODM claimed the PNU had robbed it of its rightful victory. Confident that it had won the PNU asked the ODM to launch a legal challenge in the courts. The government's hard-line position was underlined by its deployment of police and security forces in major venues in Nairobi to prevent ODM-led mass protests and threats to install a parallel government.

Stalemates partly explain the necessity for external intervention but they do not explain why particular mediators intervene. African conflicts are notable for the number of mediators who converge on them. Given the competition among multiple parties it is always critical to delineate who should mediate (Maundi, Zartman, Khadiagala \& Nuamah 2006).

5 See, eg, Gabel, Kennedy \& Wyly 2008. The inquiry into the electoral violence led by Justice Philip Waki and appointed after the signing of the agreement concurred with this characterisation of the violence.

6 On the role of stalemates in negotiations see Zartman 1988. 
In the Kenyan context the entry of mediators was complicated by a legacy of national pride that had accumulated in the years of relative political stability. Kenya had often associated mediation enterprises with failed states. When, therefore, various mediators began to propose intervention to resolve the conflict most of the country's leaders, particularly those in government, were reluctant to countenance the intrusion of outsiders. Yet despite invocation of sovereignty the traumatic violence after the elections and the potential descent into state failure made the country a genuine candidate for external mediation.

Equally significantly, critics of mediation faced sustained pressure from powerful external players concerned about the implications for the entire region of Kenya's meltdown. From the outset Western donors harped on Kenya's strategic significance in the Great Lakes and East African region. International outrage and pressure was decisive in galvanising leverage and attention that was to produce an admixture of threats of sanctions and promises of aid for economic recovery.

Three days into the violence South Africa's Archbishop Desmond Tutu emerged as the first mediator under the umbrella of the All Africa Conference of Churches (AACC). Preliminary efforts by a group of prominent Kenyans, the Concerned Citizens for Peace, led by Bethwell Kiplagat and Lazarus Sumbeiywo, to institute a locally driven mediation process had fallen on deaf ears. Archbishop Tutu intervened at a delicate moment, when there was no communication between the parties and at the height of the much publicised burning of people in churches in Eldoret, Western Kenya, and Mathare, one of Nairobi's slums.

By means of moral suasion and appeals for decency Tutu tried to induce the parties to accept international mediation. At a meeting with the ODM on 3 January 2008 he pressed for negotiations and received a commitment that Odinga would accept international mediation (East African Standard (EAS) 3 January).

Coinciding with Tutu's bid were frantic diplomatic efforts led by Western countries for an African-led mediation process. On 2 January US Secretary of State Condoleezza Rice and British Foreign Secretary David Milliband joined the African Union (AU) in a call for an end to the ethnic violence and for a 'compromise' among the political leaders 'that puts the democratic interests of Kenya first' (Daily Nation 3 January; Kpodo 2008).

At a press conference during Tutu's visit Odinga acknowledged that British Prime Minister Gordon Brown and Secretary of State Rice had proposed the AU Chairman and Ghana's President John Kufuor, Kofi Annan, and former Sierra Leonean President Ahmad Tejan Kabah as mediators. Odinga accused President Kibaki of refusing to allow mediation, ostensibly because there was 'no crisis that warranted foreign mediators'. More poignantly Odinga ruled out power sharing with Kibaki, claiming that 'I cannot share power with a dishonest person' (EAS 3 January). 
After two days of trying to secure an appointment with Kibaki Tutu finally had a meeting but failed to persuade the government to concede to negotiations. In an indication of the government stance Kibaki gave his first press conference since being declared winner, directing the security services to apply the full force of the law against perpetrators of violence. He also ruled out the formation of a transitional government and told those dissatisfied with the election results to 'go to court and follow the law'. Although hinting that the government was ready to hold 'dialogue with concerned parties' Kibaki insisted that he could only talk 'once the nation is calm and the political temperatures are lowered enough for constructive and productive engagement' (EAS 4 January).

Although Tutu's initiative was unsuccessful his presence demonstrated international attention to Kenya's plight and helped lay the groundwork for subsequent initiatives. While it secured the ODM's commitment to mediation Tutu's moral authority had no impact on the government, which was growing increasingly confident that it would overcome the post-election strains.

Part of this confidence stemmed from recognition by Uganda, whose leader, Yoweri Museveni, was the only president to congratulate Kibaki on his re-election. Wearing the hat of chairman of the East African Community (EAC) Museveni had initially tried to intervene as a mediator but the government had rejected the move. In addition, with the media reporting that Museveni had sent an army to Western Kenya to bolster the government's defences the ODM denounced him as a meddler (Bogere 2008). The government's position was also boosted by a leaked memo from World Bank Country Director Colin Bruce, reportedly endorsing Kibaki's claim to victory and dismissing as 'not thorough and precise' statements by the EU observer mission that the election had been riddled with irregularities. On 8 January 2008 Bruce wrote:

The considered view of the UN is that the ECK announcement of a Kibaki win is correct. Upon receiving the complaints from the opposition about irregularities last Saturday, the ECK spent 24 hours, in the presence of observers, reviewing each concern. On balance, they determined that there were more irregularities of consequence on the Odinga side than on the Kibaki side. For example, ECK considered reported turnout above 90 percent to be a red-flag for irregularities. Data available so far indicates that the highest reported turnout in a Kibaki stronghold was 90 percent; in the Odinga strongholds, there were 6 heavily populated areas with reported turnout of between 102 to 116 per cent.

Ndegwa, Fortunate, Ratemo \& and Ogutu 2008; Muriuki 2008; 
Although the United Nations office in Nairobi subsequently disowned Bruce's memo it lent some legitimacy to a government that was increasingly facing condemnation from some of its key Western allies. As a sign of the government's growing confidence Kibaki named a 17-member Cabinet on the eve of the arrival of AU President John Kufuor.?

President's Kufuor's arrival was delayed by mixed signals from the government, typified in the statement of Foreign Minister Moses Wetangula that: 'We did not invite him and there are no plans to invite him because we did not see the need to do so since the current crisis emanating from the elections is a Kenyan issue that can be resolved by Kenyans' (Cheboi 2008).

After some hesitation the government relented and welcomed Kufuor on 7 January. Kufuor's intervention took place alongside mounting pressure from the Bush administration for the United States to play a more active role. The presence in Nairobi of the US Assistant Secretary of State for African Affairs, Jendayi Fraser, from 4 January underlined the US administration's sense of the urgent need to expedite the negotiations.

In almost 10 days of meetings with the two principals Fraser pushed for an end to the bloodshed and for international mediation. When the government remained obdurate Fraser suggested that there could be no 'business as usual' between the US and Kenya as long as the post-election stalemate persisted. Later, at the AU summit in Ethiopia, Fraser issued the first threat of forceful action against the feuding Kenyan parties, warning that: 'We'll find an international mechanism if they can't find it internally' (see Lobe 2008).

Prior to Kufuor's visit Odinga moderated his hard-line stance demanding Kibaki's resignation, saying he would negotiate with the government in the presence of international mediators. The government, too, shifted its position on mediation, welcoming Kufuor. Kufuor's engagement, unlike that of Tutu, drew on the broader institutional anchorage of the AU and the international community. He was expected to use this broad-based power to arrange a meeting of the two leaders to map out the cessation of violence and an agenda to begin the talks. The task was made more urgent by warnings from relief agencies of a looming humanitarian emergency among tens of thousands of displaced civilians across the country. In addition a new front had opened up in the ethnic violence in Central Kenya as the Mungiki militia forced the exodus of non-Kikuyu from the region.

Shuttling between the two leaders from 8 to 11 January Kufuor found them to be hostile and uncompromising antagonists. While the ODM showed

7 In the words of a British diplomat in Nairobi, by naming the Cabinet Kibaki essentially slammed the mediation door in President Kufuor's face: 'The situation is indeed getting desperate and it is up to Kufuor to defuse it now. How he will do it is unclear because, by naming the cabinet, the government told him, thanks for coming, but no mediation please.' 
readiness for negotiations and called off mass action across the country it demanded negotiations leading to the formation of a transitional government which would help organise new presidential elections. On the other hand, the government leaned towards incorporating key ODM figures in the Cabinet Kibaki had announced. ${ }^{8}$

The government also demanded direct talks with the ODM, a position the latter described as 'public relations gimmickry' (BBC 9 January). Kufuor tried to reconcile these differences by drawing on the collective pressure of Western diplomats in Nairobi and the presence of Assistant Secretary of State Fraser, but hopes for a direct meeting between the ODM and the PNU faded amid accusations of bad faith by both sides. On the final day of Kufuor's engagement Odinga's party distributed the text of an agreement to re-examine the flawed elections and hold fresh polls, but the government disowned it (Munene \& Namunane 11 January; Voice of America 11 January).

In the aftermath of Kufuor's intervention a government minister belittled the initiative, charging that Kufuor had come to Nairobi 'to have a cup of tea' with Kibaki (Cheboi 29 December 2008). Although Kufuor failed to persuade the two leaders to meet, his shuttle diplomacy yielded a concession by the parties to break the political impasse. Before he left Nairobi Kufuor had extracted from both Kibaki and Odinga an unconditional commitment to dialogue and the use of constitutional means to resolve the conflict. More importantly, Kufuor announced that:

The parties agreed to work together with a panel of eminent African personalities headed by Mr. Kofi Annan ... towards resolving their differences and all other outstanding issues including constitutional and electoral reforms. Both sides agreed there should be an end to the violence and they also agreed there should be dialogue.

Al Jazeera 11 January

Kufuor's personal engagement played a critical role in the breakthrough but it also illustrated the shortcomings of presidential interventions in mediated processes. Presidents and other heads of state have potential clout as mediators, but they seldom have the time or the attention span to sustain protracted mediation processes. ${ }^{9}$

8 Early indications of the government's unwillingness were captured in a statement from the presidential press unit noting that Kibaki had 'assured President Kufuor that he had already initiated a process of dialogue with other Kenyan leaders to find a sustainable solution to the current political situation.'

9 Graça Machel underscored the fact that President Kufuor's mediation had not failed, observing that: 'He realized that time is needed to build bridges and to find common ground. And being Head of State he could not have much time to remain in Kenya' (Cheboi 29 December 2008, p 8). 
The choice of Annan and his team thus came at an opportune moment to build on the gains of the high-profile engagement of Kufuor and the Western envoys. Although he had expected to arrive in Nairobi on 14 January 2008 illness delayed Annan's visit for a week.

\section{ENTER KOFI ANNAN'S PANEL OF MEDIATORS 22 JANUARY TO 4 FEBRUARY}

The invocation of African solutions to African problems stems partly from the use of former heads of states and other prominent personalities to mediate in cases of civil conflict. Since the 1990s the practice of using elder statesmen as mediators has become widespread, demonstrated by the involvement of Nelson Mandela and Julius Nyerere in Burundi, Joaquim Chissano in Northern Uganda, and, more recently, Olusegun Obasanjo and Benjamin Mkapa in the eastern Democratic Republic of Congo (DRC).

In most of these cases elder statesmen have mediated as individuals supported by a wide array of local and international institutions (Khadiagala 2007). The Kenyan case, however, was the first in which the AU had requested the collective efforts of three elders in a diplomatic engagement that drew on the varying strengths and experiences of the mediators. The panel epitomised collective power - the coalescence of diverse diplomatic and moral skills that would exploit the momentum generated by Kufuor's limited breakthrough.

In taking over the leadership of the mediation from Kufuor Annan became a symbol of continuity. Given his impeccable record in diplomacy and conflict resolution Annan's strength was grounded in broad international structures of authority and leverage. His global stature and continental credibility have given him the critical mediation skills - patience, persuasion and tenacity - necessary to navigate the Kenyan quagmire. He also had the mettle to shame, threaten, and harangue the parties at decisive moments in the negotiations.

As a former president of Tanzania Mkapa represented the power of geographical proximity; he was also familiar with the principal parties, an important ingredient in winning their respect. Although soft spoken Mkapa brought firmness and forthrightness to the negotiations.

The woman in the team, Machel, who has a solid international reputation and experience in managing difficult situations, lent feminine stamina and sharpness and succeeded in disarming the parties at crucial phases of the mediation. ${ }^{10}$

10 Glimpses of the personalities of the mediators are captured in Scott Baldauf's three articles in the Christian Science Monitor on 8 August 2008. 
An additional element that worked in favour of the panel was that it was acceptable to both parties. This acceptability was to prove vital when the Kibaki government rejected the inclusion of South African industrialist Cyril Ramaphosa because of his alleged links to Odinga and the ODM.

The mediators faced an ODM negotiating team made up of James Orengo, William Ruto, former vice-president Musalia Mudavadi, and Sally Kosgei. The PNU team comprised mostly lawyers - Justice Minister Martha Karua, Minister of Foreign Affairs Moses Wetangula, and Mutula Kilonzo. The Minister of Education, Sam Ongeri, was the only member of the PNU without a legal background. In the immediate aftermath of the contested elections these three lawyers had emerged as the most consistent supporters of the Kibaki government and had developed a reputation as hardliners.

Overall, as Baldauf (8 August 2008) observed:

Together, these eight men and women were Kenya's brightest and most ambitious. And over the next five weeks, their debates on arcane points of constitutional law would form the sophisticated counterpoint to the images of vicious street fighting that were redefining Kenya in the eyes of the world.

The composition of the PNU delegation deepened the perception that the government had not entirely conceded the importance of a negotiated settlement. Furthermore, statements by other hard-line government ministers before the start of Annan's mediation underlined the intransigence about negotiations. For instance, even as Kibaki assured EU Commissioner Louis Michel on 20 January that he was ready to meet Odinga to jumpstart the negotiations John Michuki, a staunch Kibaki ally, contended that Kibaki had won and the government had no interest in inviting mediators: 'We did not invite the former presidents and Ghanaian President John Kufuor. Even Kofi Annan has not been asked to come by us. We have not complained to anybody. How can we call somebody after winning an election?' (Otieno 15 January; Ohito 20 January).

In the preparatory phase of the mediation Annan established three critical elements that would underpin it. First, he sought assurances from Western and African leaders that there would no competing mediators, a problem that perennially confronts African mediators. As he pointed out at the end of the talks: 'I said we have to make sure there is just one mediation process. Otherwise you have the protagonists trying to bottom shop, looking elsewhere if they don't like what you are offering. You get diplomatic tourism and that is not good' (Cohen 3 March; Preston-McGhie August; Kelly 16 August). The freedom from competitive mediators allowed the panel sufficient room to manage the negotiations by 
establishing the broad agenda that helped the parties frame the issues and search for mutually acceptable solutions.

Secondly, the mediation team embarked on a wide consultative process with multiple constituencies in Kenya to foster public dialogue and create confidence in the negotiations. Annan met for several days prior to the talks with leaders from religious, human rights, and business groups. There was also a deliberate effort to involve the media through regular briefings. Broad-based consultations, Preston-McGhie (August) notes, were an

important means by which the Panel and the mediation raised public confidence in the process ... Civil society provided well organized briefing papers and presentations to the Panel. Their high level of organization made these early meetings particularly useful. This also had an impact on the wide, sustained public support that the Panel enjoyed through the process as they felt that they had been heard and had a stake in the process from the outset.

As part of its engagement with the public the Annan team visited IDP camps in the Rift Valley, where violence continued to rage (Daily Nation 25 January; Bii \& Ngetich 25 January).

Finally, Annan evolved a dual mediating strategy whereby he met with the key negotiators from both sides as well as consulting regularly with Kibaki and Odinga, the principals in the conflict. This strategy put a participatory stamp on the process by committing all the key players to major decisions, but it also became vital towards the end, when the talks deadlocked, a situation only the principals could resolve.

In a major breakthrough that initiated rapport between the principals Annan brokered a handshake between Kibaki and Odinga on 24 January. Annan took the opportunity to commit them to expeditious negotiations and respect for the final outcome. In addition, he reiterated the importance of their leadership in ending the crisis. ${ }^{11}$

When the negotiations began on 29 January the mediation team defined the crisis in political terms that required political solutions. Sidestepping the

11 Throughout the negotiations Annan reiterated the theme of the responsibility of leaders to get the country out of the crisis. For instance, at a press conference on 8 February, he chastised the leaders: 'You have heard the business community talk about what this crisis is doing to the economy. 49000 people have already lost their jobs and more may be on the way. Farmers can't get to the farm to till their land; some cannot get their produce to the markets. Women, children and men are displaced in the open sun. Is this what leaders are put in the office to do? So they realize they have a responsibility ... They know they have a great responsibility and they know what the people and the nation expect of them.' 
contentious question of who won the election Annan tried to get the parties to think positively about the road to peace. Sensing a stalemate he encouraged both parties to contemplate a power-sharing solution that would benefit the country. As he remarked later:

Kibaki's team kept saying, 'We won it fair and square', as Odinga's countered, 'You stole it fair and square'. Kibaki ... talked of 'accommodating' the opposition; Odinga ... bridled. If pushed, he would form 'an alternative government'. It took a while to convince them that there was no way either side could run the country without the other, that it was a perfect political gridlock.

Cohen 3 March

The panel presented the parties with a programme consisting of four core components:

- Agenda One: immediate action to stop violence and restore fundamental human rights.

- Agenda Two: addressing the humanitarian crisis and promoting national reconciliation.

- Agenda Three: negotiations on how to overcome the current political crisis.

- Agenda Four: Developing long-term strategies for durable peace.

To expedite the talks the parties agreed that the first three items would be resolved within seven to 15 days from the start of the dialogue, while the fourth would be resolved within a year ('Joint Statement by the Kenya National Dialogue and Reconciliation' 1 February; Namunane 29 January; Daily Nation 30 January).

The talks began amid relentless international pressure, demonstrated in the decision of the EU and the World Bank to curtail assistance to Kenya. The EU Council, for instance, made it clear that its relations with Kenya would be put in abeyance until a sustainable and consensual political solution was found. Noting that the political impasse and violence had greatly affected donors' engagement with Kenya as well as EU-Kenya relations, the council warned: 'Until a legitimate solution is agreed, the EU and its member states cannot conduct business as usual with Kenya' (Otieno 31 January).

One of the programmes most affected by the suspension of aid was the Governance, Justice, Law and Order Sector Reform Program, which lost \$41-million in donor funds. Similarly, in a reversal of its pro-Kibaki stance, the World Bank announced on 28 January that it would consider suspending or cutting 
some of its aid programmes if a diplomatic solution to the political crisis was not found (Redfern 28 January).

When the negotiations (dubbed the Kenya National Dialogue and Reconciliation) began at the Serena Hotel in Nairobi the mediators set a deadline of two weeks in which to reach an agreement. The focus on reducing violence became more urgent with a fresh round of bloodletting stoked by the murder of two ODM members of Parliament. With both parties conceding that the violence was no longer confined to protests against the disputed election results and afraid of losing the political ground to militias it was easy for the mediators to reach a quick consensus about the need to end the violence.

Odinga poignantly admitted that violence was out of control: 'Death and despair are everywhere. The very foundation of the state is crumbling. Violence is spiraling out of control ... Yet we ourselves have resolved to act quickly to save our nation. If we don't, there might be no nation to save' (McCrummen 30 January, p A1).

On 1 February the teams reached agreement on ending the violence with a plan to disarm militias accused of ethnic attacks in Western Kenya and the opening of roads that had been blocked by demonstrators. The agreement also required the government to investigate charges of excessive use of force by the police (McCrummen 2 February, p A11).

Thanks to a combination of appeals for calm and the clampdown by security forces violence receded markedly, enabling the parties to move quickly on negotiations about measures to restore fundamental rights and liberties and tackle the humanitarian crisis, the settlement of internally displaced people, and the promotion of national healing and reconciliation. By 4 February the parties had completed negotiations on all the issues included in the second point on the agenda (Kenya National Dialogue and Reconciliation 4 February). Agreement on these issues paved the way for negotiating the more contentious question of power sharing.

\section{NEGOTIATING POWER SHARING 5-28 FEBRUARY}

The power-sharing negotiations proved more intractable, consuming three and half weeks of the negotiation period. The strategy of the mediation team was to avoid what Annan referred to as a 'who-won-who-lost' mentality and the invocation of 'reruns and recounts', by focusing on the idea of sharing power between equals.

Annan believed that, given the close result, a coalition government would be the best way to restore calm and create a basis for future reforms. Furthermore, 
the mediation team expanded the range of constitutional issues about which the parties could negotiate to prevent the future recurrence of electoral crises. The mediators' approach was to give the parties the opportunity to make written representations stating their positions, to clear up misunderstandings, determine underlying interests or concerns, find areas of agreement, and, ultimately, to incorporate those areas of agreement into resolutions (Cohen 3 March; Baldauf 8 August; Preston-McGhie August).

Having presented a broad road map for power sharing the mediation team faced the task of convincing the widely divided parties to move toward a common position. Having survived the outcry over the appointment of the Cabinet the government felt more legitimate and in control. Consequently the Kibaki team dismissed the power-sharing proposal, claiming they could not sit in the same government as ODM leaders who had instigated violence.

One report recorded that Annan 'endured harangues from Justice Minister Martha Karua, who said she was "breathless" at how Annan was "encouraging violence and lack of respect for the rule of law" by demanding power sharing with Odinga' (Cohen 3 March). Moreover, some factions within the PNU still insisted that the ODM should take its grievances to court and pushed for a recount of the presidential votes, expressing confidence that Kibaki would win.

The ODM, for its part, tabled a seven-point proposal whose key pillars included the resignation of Kibaki to pave the way for a rerun of the presidential election and the installation of a transitional government based on the parliamentary strength of each party. The ODM team stated that in view of evidence of alleged electoral fraud by the ECK and its 'incompetence, partisan and reckless conduct' a re-tally or recount was untenable, as the integrity of the electoral material had been violated.

It further claimed that a presidential rerun was 'absolutely necessary to restore the confidence of the Kenyan people in democratic elections'. ${ }^{12}$ The parties articulated these contrasting positions in two days of talks starting on 5 February. The mediation team permitted them to present evidence to support their claims.

During the third week of negotiations the parties began to move slowly away from their divergent positions. First to concede was the ODM, which dropped its insistence that Kibaki should resign ahead of an election rerun. As Odinga stated, on 7 February: 'Initially, our stand was that we won the elections and Kibaki did not; that he should resign and we be sworn in. But we are not static on that point. We are willing to yield' (Oyaro 11 February).

The PNU withdrew its demand that the ODM challenge the election in

12 For the positions of the parties see EAS 6 February and Namunane 6 February. 
court and accept a recount of the presidential vote. Despite these concessions there were serious disagreements between the parties over how to share power and the institutional arrangements that would be required to implement the agreement.

With both sides stalemated on these issues the panel consulted the principals on 8 February in a bid to expedite the negotiations, but neither side was prepared to make any concessions. Annan attempted to drum up support for a power-sharing deal by appealing directly to members of Parliament and to the two principals to 'support their negotiators and give them instructions to settle' (press conference 8 February).

Annan used his address to Parliament on 11 February to unveil his powersharing concept, proposing a 'grand coalition' to last for two years, after which a new election would be held.

Grand coalitions have served other nations well. A coalition government is an open option when a country is in a crisis and right now we are faced with a serious political crisis. The two sides come together and commit to sort out issues such as constitutional reforms and then organize an election.

Oyaro 12 February

To emphasise the importance of Parliament to the peace process Annan told parliamentarians they would be responsible for passing the constitutional, legal, and institutional reforms after the signing of the final agreement: 'You will need to work together to implement this heavy [legislative] agenda. Your active involvement, across party lines, is necessary. Without this, the Government may be paralyzed. You cannot afford to fail' (Namunane 11 February; Oyaro 12 February).

Karua denounced the mediators' proposal, maintaining that the matter had not been discussed at the talks and that the PNU's position had been misrepresented. Annan later stated that his statement represented his own views on the discussions and did not imply a formal agreement between the two parties (Press statement 13 February; see also Namunane 12 and 13 February).

Following the parliamentary briefing the negotiations moved to Kilaguni Lodge in Tsavo National Park to avoid what Annan called 'selective leaks', which were hampering the talks (Baldauf 8 August). ${ }^{13}$

In a bid to pressurise the parties to expedite the negotiations the mediation

13 According to an observer, 'A new venue serves two purposes. It breaks the monotony of meeting in the same boardroom to discuss the same issues and it also takes the two teams away from the constituencies who may be urging each side to fight on.' 
team set high expectations for the Kilaguni talks by announcing that a deal could be struck within 48 to 72 hours (EAS 12 February). To help with the negotiations the mediation team invited German Deputy Foreign Affairs Minister Gernot Erler to make a presentation on Germany's experience with a grand coalition government after the bitterly fought elections of 2005.

Taking the negotiating teams through a four-chapter presentation that touched on the principles of a grand coalition, preparation of a coalition agreement, the role of Parliament and conditions for the long-term success of the arrangement, Erler said: 'I told my colleagues that a grand coalition is not about love for each other, but about pragmatism. It is not easy to come together after a bruising election campaign so it is equally important to have good mechanisms in place' (Agina, Ohito \& Ndegwa 15 February).

In two days of negotiations in the serenity of Tsavo National Park the teams, working in both mixed and individual groups, tried to tackle the key issues related to overcoming the political crisis. They reached consensus on the formation of an independent review committee which would have three to six months to inquire into the flawed presidential election.

The committee would also make recommendations about improving the electoral process, and its findings would be relevant to the envisaged comprehensive constitutional review. It was also agreed that a truth, justice and reconciliation commission would be established and reforms instituted to deal with issues such as reconstruction, correcting historical injustices, land reform, equity and devolution, the independence of the judiciary, and the reconstitution of the electoral commission and establishment of new constituencies (Daily Nation 14 February). The negotiations also put to rest a contentious issue with which the negotiators had wrestled from the start, as Annan (15 February) indicated:

Through the discussions, it became apparent that there is no viable way, either by a recount, re-tally, or any other measure, to determine the outcome of the 2007 elections in a way that would be expeditious and that would not further divide Kenyan society. All the options could only give us a quick fix to the problem but could not address the truth that we were looking for and we therefore agreed on a political solution which could involve bringing the parties together. However, the facts have to come out and Kenyans have to know what happened. We agreed that the system must be reformed so that such a crisis never happens again.

The agreement belied the deep divisions over the core of the governance arrangements. At Kilaguni the parties tabled contrasting governance proposals, the 
ODM pushing for a coalition government with executive power shared among a prime minister, two deputies, the president, and the Cabinet. Such a government, the ODM argued, would be based on shared and delegated executive authority, proportionality at all levels, and balanced portfolios. It staked its claim to 55 per cent of Cabinet positions, leaving 45 per cent for the PNU and its alliance parties. Reeling from what it perceived as undue pressure from the Annan team the PNU argued that the ODM proposals were so fundamental that Parliament, on its own, could not pass them. Such far-reaching changes, the PNU contended, would require a national referendum because they entailed changing the government structure from a presidential to a parliamentary system. Instead, the PNU negotiators proposed a non-executive prime minister to serve at the pleasure of the president; further, they suggested that the president should have the prerogative to decide which members of the ODM should join the Cabinet.

The negotiations turned acrimonious and the Annan team adjourned the talks to allow the mediators to consult with Kibaki and Odinga. ${ }^{14}$ In a press briefing on 15 February Annan put a brave face on the Kilaguni talks, underscoring the achievements made since the negotiations had begun in January. But he also cautioned that:

Milestones and benchmarks for the implementation of the reform agenda will be defined in our continuing discussions. I know that many of you have been eager to write the headline, 'We have a deal' on all the political issues. But I again advise patience. The issues are complex; reaching compromise is difficult. But let me assure you that there is real momentum. We are at the water's edge and the last difficult and frightening step will be taken. I am confident that, in the interests of Kenya and its people, the parties will show the wisdom, flexibility, and foresight to conclude an agreement ... On the issue of governance arrangements, the parties discussed the matter intensively and have developed a number of options, on which they have agreed to consult their principals and leadership and come back to continue negotiations on Monday [18th], with the hope that a final conclusion will be reached shortly after that. This is the only outstanding issue on Agenda Item 3 - How to Resolve the Political Crisis. In summary, we have defined the reform agenda for a new government and are now discussing the 'how' and the mechanisms required for implementation.

EAS 16 February; Agina, Ohito \& Ndegwa 15 February 
The resumption of the talks on 18 February coincided with a high-level visit to Nairobi by US Secretary of State Rice, as part of the deepening pressure on the PNU to relax its hard-line position on power sharing.

\section{MOBILISING INTERNATIONAL PRESSURE AND ELICITING THE PNU'S IRE}

In the aftermath of the Kilaguni talks the mediators recognised that sustained international pressure was the key to unlocking the gridlock. It was particularly necessary to pressure the government negotiators, who seemed to be playing for time in the hopes of wearing down the opposition and the resolve of the international community.

Previous coordinated international pressure, including the suspension of foreign assistance, had been critical in getting both parties to the negotiating table, but it was proving difficult to persuade the government to make new concessions on power sharing. To reinvigorate the talks Annan had to draw again on the weight of the international community in a coordinated effort to induce the government to accommodate opposition demands.

The strategy of escalating international pressure, however, carried its own risks, particularly since the government was feeling besieged by Western donors - some hardliners in the PNU were contemplating an 'internal solution' to the crisis. Although Western countries had concluded that Kibaki's allies were impeding a negotiated settlement the dilemma was how to pressurise the PNU without alienating it entirely.

Already there was a creeping perception among government hard-liners that the mediation process had become a device by which the opposition, abetted by the West, would force its way into government though the route of an unelected executive prime minister. Even though Annan assured the parties that the mediation would not impose a solution, the increasing fear in government of Annan's bias towards the ODM burst into the open. ${ }^{15}$

After the Kilaguni talks Karua blamed Western donors for interfering in Kenya's domestic affairs: 'It is unfortunate to note that some diplomats are abusing Kenya's hospitality by giving their unsolicited views on the mediation talks ... I would like to remind them we are not a colony ... I urge them to refrain from such behaviour and adhere to the diplomatic convention of not interfering with sovereign states' (Daily Nation 14 February).

International pressure was galvanised by the visit in mid-February of the Secretary General of the United Nations, Ban Ki-Moon. Underscoring support

15 For an excellent summary of the PNU's view see Gaitho 19 February. 
for the Annan mediation Ban warned Kenyan leaders that they bore 'a particular political responsibility for the future of Kenya'.

I stressed to all Kenyan leaders the need to stop the unacceptable violence and killings and to resolve their differences through dialogue and the democratic process. I also appealed to all the political leaders to think beyond their individual interests or party lines, and to look to the future of Kenya as one country.

\section{EAS 12 February}

At the same time, the EU warned that it would sever trade and bilateral links with Kenya if political leaders do not move rapidly to resolve the crisis: 'The electoral process had a negative impact on the country, and until there is a willingness in the two opposing factions to work things out together, it will not be business as usual as regards EU member countries.' The warning was directed at 'any party or individuals' who sabotaged the Annan-led talks. Furthermore, the EU contended that 'Kenya is a vital country in this region and the international community is not ready to watch it slump into anarchy. If we allow it, other countries in this region would be affected and this will be a threat to the stability of the African continent' (Nyasato \& Saulo 15 February; Bartoo 12 February; Otieno 16 February).

Sending Rice to Nairobi in mid-February US President Bush indicated that her mandate was to support the Annan effort and 'deliver a message directly to Kenya's leaders and people: there must be an immediate halt to violence, there must be justice for the victims of abuse and there must be a full return to democracy' (Otieno 16 February). During extensive consultations with the parties and the mediators on 18 February Rice came down strongly on the side of a grand coalition government: her mission seemed targeted at putting more pressure on Kibaki to accept a power-sharing deal. As she put it:

It cannot be an illusion; power sharing must be real. To the president, President Kibaki, I will say power sharing means real power sharing and the US as a friend of Kenya expects that power sharing to take place to show that you can make the electoral and constitutional reforms that frankly should have been made several years ago. To Mr. Odinga, I will be saying that we understand that the election was problematic, the United States has said that, but again power sharing does need to take place. An agreement really needs to be concluded. There needs to be a governance arrangement that will allow real power sharing that will allow a coalition, a grand coalition, so that Kenya can be governed.

Rice 18 February; see also Namunane 24 February 
Rice reported that the US government had drawn up a list of Kenyan leaders (most of them from the PNU) who would be barred from entering the US because they were impeding the search for a negotiated settlement. The British ambassador also hinted that his government would freeze the assets of those targeted by the visa ban (Mwaura 16 February).

In the aftermath of Rice's high-profile intercession the negotiations resumed on 19 February but on a sour note, with Karua escalating the accusations against Annan and charging that the mediators favoured the ODM. She also accused Annan of trying to engineer a 'civilian coup' by proposing that Odinga should be made prime minister and be given substantial executive powers.

When Karua blamed the international community for 'pushing an agenda that had led to the loss of lives and the destruction of property' Annan complained that her comments were 'unfair and insulting to the international community and African leaders who had come forward to help Kenya' (Cohen 3 March).

Karua's combative tone set the pace for the discordant negotiations that followed. Although the mediators helped the parties establish a legal committee to work on the contentious power-sharing provisions and draft a preliminary agreement PNU negotiators were steadfast on the issue of the appointment of the prime minister, his powers, and constitutional standing.

The government insisted that the prime minister be appointed without the need to alter the Constitution, but, smarting from the experience of 2003 when the Kibaki administration revoked the pre-election Memorandum of Understanding (MoU) with Odinga's faction of NARC as soon it came to power, the ODM demanded the position be enshrined via a constitutional amendment (Obonyo 24 February; Inter Press Service 24 February; EAS 25 February). With the parties engaging in brinkmanship Annan decided to postpone the talks and appeal directly to Kibaki and Odinga.

\section{BACK TO THE PRINCIPALS}

After five weeks of inconclusive talks Annan decided that the stalemate could be broken only if Kibaki and Odinga personally and directly negotiated an agreement. As he explained it:

Given the way the talks are going and the negotiators are relating to each other, I believe it is important that I suspend the negotiations, not as an act of desperation or giving up, but suspend the negotiations and take the matters up with President Mwai Kibaki and the Honourable Raila Odinga. The leaders have to assume their responsibilities and become directly engaged in these talks. Because 
the way it is going now, if I do not get them to engage, and get them to give the instructions or negotiate directly with me, the process might take longer.

26 February

The decision to engage the principals at this crucial point was momentous because the negotiators seemed incapable of resolving the impasse. But it was also possible to appeal to the two leaders directly because, from the start, they had been included in the negotiations through briefings and consultations. More vitally, the strategy of meeting the principal players directly allowed the mediators to isolate the hardliners on both side of the political divide who had resorted to brinkmanship and prevarication as the talks reached closure. The appeal to Kibaki and Odinga was further facilitated by the fact that the two had evolved a functional working relationship of respect and understanding in the course of the negotiations.

The mediators' strategy was to have a series of separate talks with Kibaki and Odinga to sound them out on the outstanding issues. In two days of shuttle diplomacy, Annan confronted hardened positions on power sharing. After meeting Annan on 27 February Kibaki issued a press statement announcing that he was ready to appoint a prime minister in a 'coalition government' but that most of the pending issues would be addressed under the existing Constitution.

Odinga responded immediately, claiming that the ODM was interested in a power-sharing agreement or a transition government that would immediately embark on constitutional reforms: 'We are not merely interested in power sharing for the sake of it. We want a transitional government that will embark on legal, institutional and constitutional reforms. We will share power in a government that is reform geared' (Ohito 28 February).

Facing another deadlock Annan convinced the principals to sit together and hammer out an agreement in the presence of Tanzanian President and AU Chairman Jakaya Kikwete on 28 February. This session, dubbed the 'Meeting of the Five', marked the endgame in the negotiations. Principals and mediators worked for almost five hours on drafts prepared by the legal team to resolve the deadlock. As one of the participants in the mediation team noted:

In preparation to meet the principals together on the $28^{\text {th }}$ February, a draft of the Act was prepared with proposed compromise language. This was the basis of the five hour marathon meeting that followed. Despite protocol of previous meetings where the cabinet ministers had sat in with the President, Mr. Annan made it very clear that this was to be a meeting only of the five. This included President Kibaki and Raila Odinga, Mr. Annan, Former President Mkapa and President 
Kikwete ... The Tanzanian model, with a strong Prime Minister as well as a strong President was an important example to draw on in Kenya, and therefore the presence of Presidents Mkapa and Kikwete was particularly critical.

Preston-McGhie August

Throughout the meeting Kibaki maintained that it would be unacceptable to make Odinga a prime minister with executive powers, including 'authority' over the Cabinet, because this would create another centre of power. Similarly, on the contentious issue of amending the Constitution to entrench the proposed coalition and safeguard the prime minister's post and those of his two deputies, Kibaki was adamant that all clauses of the agreement and the Act should be in line with the provisions of the existing Constitution (Namunane 28 February). It took the collective weight of those gathered to shift Kibaki from these positions.

The power-sharing agreement, the National Accord and Reconciliation Act, was signed on 28 February 2008. Although it was only one of several agreements between Kibaki and Odinga the National Accord was undoubtedly the most influential in establishing the parameters and principles of a coalition government. Its main objectives were to create the positions of prime minister and two deputy prime ministers and establish a coalition government comprised of Cabinet appointees from both the PNU and the ODM. It also granted the prime minister the authority to coordinate and supervise the functions of government and provided that the prime minister and his deputies can only be removed from office through a parliamentary vote of no-confidence.

Thanks to pressure from the ODM it was enshrined in the Constitution by means of a constitutional amendment passed by Parliament on 19 March and subsequently enacted, with Odinga as prime minister. After weeks of negotiations between the two principals over the sharing of ministerial slots, on 13 April Kibaki named a 42-member Cabinet that pledged to heal the rifts created by the ethnic animosities that had threatened to tear the nation apart.

Following the departure of Annan, Oluyemi Adeniji, a Nigerian diplomat, took over the mediation of Agenda Four, which addressed long-term issues such as the Constitution and the establishment of the Justice and Reconciliation Commission and dealt with historical injustices. But mediating long-term issues proved difficult in the light of the change of mediator and the appointment of members of the negotiating team to Cabinet positions in the grand coalition government.

Most of the members of the negotiating team believed the signing of the National Accord essentially meant the end of the mediation process. Furthermore, there was laxity in negotiating these issues because of the perception that the 
coalition government would resolve most of the long-term questions through internal constitutional and legislative mechanisms. As a result the negotiators only worked out the details of the items on Agenda Four that had already been agreed upon such as the establishment of the Truth and Reconciliation Commission, the Independent Review Commission on the 2007 elections, and the Commission of Inquiry into the Post-Election Violence. By the end of June 2008 the negotiations had become moribund, with members of the negotiating team attending meetings only sporadically (EAS 3 March; 4 March; 8 June).

\section{CONCLUSION}

In the aftermath of the agreement some Kenyan analysts paid disproportionate attention to the alleged clout and influence of Tanzanian President Kikwete in the final breakthrough, noting that, as chairman of the AU, he had pushed the recalcitrant Kibaki government to make the meaningful concessions that led to the historic resolution.

Annan and some members of the mediation team, however, claimed that the successful mediation epitomised the triumph of a new international practice, the Responsibility to Protect (R2P), whereby the international community is obliged to save states from descending into chaos (Oluoch 28 February; Namunane 28 February; Cohen 3 March; Preston-McGhie August).

Although both explanations have some validity they verge on single-path explanations that diminish the importance of a convergence of circumstances which seem unique to the Kenyan context. The role of Kikwete - wearing two hats: president of a neighbouring member of the East African Community and chairman of the AU - gave the AU a boost in conflict resolution after its dismal performance elsewhere on the continent. Though his intervention came at a time when the negotiations were on the brink of collapse the parties had broken sufficient ground to reach agreement on outstanding issues.

Annan's successful handling of the mediation was also not a result of a broader acceptance of R2P, a principle that the international community has failed to put into practice in much more protracted and contentious internal conflicts. The panel members' effectiveness as interlocutors inhered in their ability to manage the intricate balance between international pressure and a local context in which the parties gradually learnt the importance of mutual accommodation.

In the course of the negotiations the parties that had previously worked together stepped from the brink of disaster and sought bilateral solutions, particularly in the face of national yearning and pressure for peace. Threats of sanctions by the EU and several other countries worked in concert with that longing for peace. 
Annan and the mediation team took advantage of the stalemate, but also skilfully used the international attention converging on Kenya's instability to propel an agreement with which the parties felt comfortable. Equally germane, the warming of the relationship between the two principal protagonists (an outcome of the negotiating dynamics) had the effect of easing the work of the mediators. As Sally Kosgei, a member of the ODM team, acknowledged:

Adversaries or not, we had a collective responsibility, which propelled us to upgrade our thinking to appreciate that we were not adversaries, we held divergent views, which needed to be narrowed to achieve peace. Our views of the way forward nearly converged, but not quite, that was left to the two principals to agree and sign.

EAS 23 November

Soon after the agreement was signed Annan was quoted as stating that he 'never doubted that Kibaki and Odinga would eventually agree to a compromise. He had been briefing the two leaders throughout the talks, and despite the obstinacy of their mediation teams, he felt they were both ready to abandon their maximum positions for the common good' (Baldauf 8 August).

Mediators of internal conflicts often confront government appeals to sovereignty, a problem Annan had to deal with throughout the negotiations. Although top government officials were uncomfortable with the involvement of foreigners in the conflict and railed against the imposition of a foreign-crafted political compromise, the government had to relent against the backdrop of international pressure and the legitimacy crisis stemming from the widespread perception that Kibaki had 'stolen' the elections.

Annan's forceful determination (backed by a unified and consistent international voice) that a political settlement would entail power sharing was crucial in undercutting the sovereignty argument.

Ultimately parties in the Kenyan conflict appreciated the work of Annan, who was feted as the saviour of the nation. Even Karua, a staunch opponent of foreign mediation, conceded the value of the agreement: 'It was a terrible process, but a worthwhile goal. At the end we were able to support it, because it restored a sense of normalcy. The agreement stopped the violence and brought back a semblance of peace. It restored our sovereignty and control over our own affairs' (Baldauf August 2008). 


\section{- REFERENCES -}

\section{Books and journal articles}

Ajulu, R. 2002. 'Politicized Ethnicity: Competitive Politics and Conflict in Kenya: A Historical Perspective'. African Studies 61(2).

Barkan, J. 2004. 'Kenya after Moi' . Foreign Affairs 83(1), January-February.

Branch, D \& N Cheeseman. 2009. 'Democratization, Sequencing, and State Failure in Africa: Lessons from Kenya'. African Affairs 108, January.

Elischer, S. 2008. Ethnic Coalitions of Convenience and Commitment: Political Parties and Party System in Kenya. Hamburg: German Institute of Global and Area Studies, Working Paper No 68, February.

Grignon, F, M Rutten, \& A Mazrui (eds). 2001. Out of the Count: The 1997 General Elections and Prospects for Democracy in Kenya. Kampala: Fountain Publishers.

Karume, S. 2003. 'Factional Intrigues and Alliance Politics: The Case of NARC in Kenya's 2002 Elections'. Journal of African Elections 2(2).

Khadiagala, G M. 2007. Meddlers or Mediators? African Interveners in Civil Conflicts in Eastern Africa. Leiden: E. Brill.

2008. 'The Failure of Leadership in Kenya's Electoral Process'. Journal of African Renaissance 5(2).

Klopp, J. 2001. 'Ethnic Clashes and the Winning of Elections: The Case of Kenya's Electoral Despotism'. Canadian Journal of African Studies 35(2).

Maundi, M, I W Zartman, G M Khadiagala \& K Nuamah. 2006. Getting In: The Entry of Mediators into the Settlement of African Conflicts. Washington, DC: The United States Institute of Peace.

Ndegwa, S. 2003. 'Kenya: Third Time Lucky'. Journal of Democracy 14(3).

Oyugi, W, P Wanyande \& M Odhiambo (eds). 2003. The Politics of Transition in Kenya: From KANU to NARC. Nairobi: Heinrich Boll Foundation.

Preston-McGhie, M. 2008. Preventive Diplomacy and the Kenya Crisis. Geneva: Center for Humanitarian Dialogue, August.

Zartman, W. 1988. Ripe for Resolution: Conflict Resolution in Africa. London: Oxford University Press.

\section{News reports and press releases}

Agina, B, D Ohito \& A Ndegwa. 2008. '48 hours Later ... and no Deal Yet'. The East African Standard, 15 February.

Al Jazeera. 2008. 'Kenya Mediation Fails', 11 January.

Annan, K, B Mkapa \& G Machel. 2008. 'Partial Transcript of a Press Conference'. Nairobi, 8 February. 
Annan, K. Kenya National Dialogue and Reconciliation, Press Conference. Nairobi, 13 February.

2008. ‘Opening Statement by H. E. Kofi Annan Press Conference'. Nairobi, 15 February.

2008. 'Transcript of Elements of Press Encounter by H.E. Kofi Annan In front of the Nairobi Serena Hotel'. Nairobi, 26 February.

Baldauf, S. 2008. 'After two months of discord, finally a handshake'. The Christian Science Monitor, 8 August.

2008. 'Africa's elders seize a leading role'. The Christian Science Monitor, 8 August.

2008. 'Why the Kenya talks Succeeded'. The Christian Science Monitor, 8 August.

Ban Ki-Moon. 2008. 'Opinion'. East African Standard (EAS), 12 February.

Bartoo, V. 2008. 'Envoys' Warning over Talks', EAS, 12 February.

BBC. 2008. 'New Efforts to Solve Kenya's Crisis', 9 January.

Bii, B \& P Ngetich. 2008. 'Chaos in North Rift Unmasks Historical Disputes over

Land and Cattle Rustling'. The East African Standard, 25 January 25.

Bogere, H. 2008. 'Uganda maintains it has not deployed troops in Kenya'. The Nation, 20 January.

Cheboi, S. 2008. 'When Ghanaian Head of State Flew all the Way "for Tea"'. Daily Nation, 29 December.

2008. 'In spite of Initial Hiccups, Annan Saved the Nation'. Daily Nation, 29 December.

Cohen, R. 2008. 'African genocide averted'. New York Times, 3 March.

Daily Nation. 2008. 'New Government the Way Out: Annan', 16 February.

2008. 'Western Powers Condemn Violence in Kenya', 3 January.

2008. 'Clashes Erupt in Kenyan Town after Leaders' Hopeful Handshake', 25 January.

2008. 'Rival Teams Meet in Second Step toward Peace', 30 January.

2008. 'Annan Pleads for Grand Coalition Government', 13 February.

2008. 'Annan's Team Strikes Half-Way Deal in Talks', 14 February.

2008. 'Revealed - Secrets of Talks with Rice', 24 February.

East African Standard. 2008. 'Tutu Received at Orange House', 3 January. 2008. 'Press Conference of President Kibaki', 4 January.

2008. 'Kibaki, Raila and Annan Speak', 25 January.

2008. ‘Parties Prepare for a Showdown', 6 February

2008. 'Annan: Deal could be struck in 48-72 hours', 12 February.

2008. 'Annan: What we Have Agreed on so Far', 16 February.

2008. 'Fresh Urgency as Talks Resume', 25 February.

2008. 'Annan Leaves as Talks Team Tackle Agenda Four', 3 March. 
2008. 'Man Who Wears Annan Shoes is a Top-Notch Peacemaker', 4 March. 2008. 'Adeniji Speaks Out', 8 June.

2008. 'How we Achieved Peace', 23 November.

Economist, The. 2008. 'Kenya: Kibaki v Odinga: No Compromise Yet', 10 January.

Gabel, K, B Kennedy \& K Wyly. 2008. 'Rights Activist Pushes for UN Action:

Interview with Maina Kiai, Chairman of the Kenya National Commission on Human Rights', allAfrica.com, February 12.

Gaitho, M. 2008. 'Coalition Deal May be Skewed in Several Ways'. EAS 19 February.

Kareithi, A. 2008. 'UN disowns alleged memo in support of Kibaki's win'. 2008. $E A S, 12$ January.

Kelly, K J. 2008. 'US Journalist Reveals Details of Annan-Led Talks'. The East African, 16 August.

Kenya National Dialogue and Reconciliation. 2008. Joint Statement, 1 February, Nairobi.

Kpodo, K. 2008. 'African Union plans Kenya mediation, Tutu Arrives'. Reuters, 2 January.

Lobe, J. 2008. 'Kenya Seen as Anchor to U.S. Position in the Region'. Inter Press Service (Johannesburg), 8 January.

McCrummen, S. 2008. 'Opposition Legislator Slain In Kenya, Sparking Clashes'. Washington Post, 30 January.

2008. 'Kenyan Rivals Agree on Measures to End Post-Election Violence'. Washington Post, 2 February.

Munene, M \& B Namunane. 2008. 'Peace Talks Deadlock'. Daily Nation, 11 January.

Muriuki, A. 2008. 'World Bank Boss Under Fire'. Business Daily (Nairobi), 10 January.

Mushtaq, N. 2008. 'What a Prime Minister Might - And Might Not - Do'. Inter Press Service (Johannesburg), 24 February.

Mwaura, P. 2008. 'Fair Play - Envoy Should Name and Shame those Involved in US Visa Ban'. Daily Nation, 16 February.

Namunane, B. 2008. 'Annan's Peace Agenda'. Daily Nation, 29 January. 2008. 'Team Discusses Disputed Presidential Poll Results'. Daily Nation, 6 February.

2008. 'Talks to Focus on Two Key Proposals'. Daily Nation, 11 February. 2008. 'Party Proposals for Annan Peace Deal'. Daily Nation, 12 February. 2008. 'Kikwete's Frantic Bid to Resolve Premier Row'. Daily Nation, 28 February Ndegwa, A, E Fortunate, J Ratemo \& J Ogutu. 2008. 'World Bank Boss' Leaked Memo Stirs Controversy'. EAS, 11 January.

Nyasato, R \& M Saulo. 2008. 'EU Warns of Sanctions if Talks Fail'. EAS, 15 February. 
Obonyo, O. 2008. 'PNU's Hurdles Undermining Search for Settlement'. EAS, 24 February.

Ohito, D. 2008. 'EU Meets Kibaki, says he's willing to See Raila'. Daily Nation, 20 January. 2008. 'Kibaki's Coalition Proposal over Post Dismissed'. EAS, 28 February.

Oluoch, F. 'How Kikwete, New Darling of the West, Saved Kenya from Collapse'. EAS, 28 February.

Otieno, J. 2008. 'Ministers Disown Political Referees'. EAS, 15 January. 2008. 'Donors Suspend Key Funding'. EAS, 31 January.

2008. 'Foreign Missions in Dilemma over Crisis'. EAS, 16 February.

Oyaro, K. 2008. 'Hopes of a Breakthrough in the Post-Election Crisis'. Inter Press Service (Johannesburg), 11 February. 2008. ' "Grand Coalitions Have Served Other Nations Well” - Annan'. Inter Press Service (Johannesburg), 12 February.

Redfern, P. 2008. 'World Bank May Cut Aid If No Political Solution is found'. The East African, 28 January.

Rice, C. 2008. 'Transcript of Statement of US Secretary of State Condoleezza Rice with Former UN Secretary General Kofi Annan'. Nairobi, 18 February.

Voice of America. 2008. 'AU Mediation Talks End in Failure', 11 January.

\section{Legislation}

National Accord and Reconciliation Act 2008. Nairobi: Government Printer. 


\title{
KENYA's 2007 ELECTIONS: DERAILING DEMOCRACY THROUGH ETHNO-REGIONAL VIOLENCE
}

\author{
Rok Ajulu
}

Rok Ajulu is Professor of Political Economy and Head of the Postgraduate Diploma course in International Relation and Diplomacy, University of South Africa e-mail: ajular@unisa.ac.za

\begin{abstract}
The outcome of Kenya's 2007 general elections exposed the soft underbelly of the Kenyan political economy. A country that, until 28 December 2007 , seemed built on a solid foundation suddenly collapsed into warring ethnic constituencies, and revealed the fragile foundations upon which the post-colonial Kenyan state was built. Kibaki's decision to steal the 2007 presidential election resulted in a spiral of violence unlike any in Kenya in 44 years of political independence. In less than one month more than 1000 people died in gruesome ethnic clashes and another 300000 were displaced. Since then, commentators, scholars and analysts have sought to understand why such gruesome acts of violence could actually take place in what has traditionally been considered an oasis of peace in an otherwise conflict prone region. What went wrong? Why did Mwai Kibaki refuse to concede defeat, and instead opt for a semi-secret swearing in at a private ceremony at State House, disregarding the public ceremony for which the armed forces had been preparing? Why did the electoral commission, supposedly an independent body, fail to follow its own due processes? And how do we explain the violent reaction to Kibaki's illegitimate extension of his incumbency?
\end{abstract}

\section{INTRODUCTION}

This paper offers an explanation for the recent Kenyan electoral crisis by attempting to provide answers to the questions posed above. I suggest that the spiral of violence that erupted in response to Kibaki's theft of the 2007 election was a symptom of a much deeper crisis in Kenya's political economy, reflecting, 
as it were, deep-seated frustrations rooted in the socio-economic injustices of landlessness, joblessness and poverty that have beset the country since independence.

I suggest, further, that the crisis of democratisation in post-colonial societies, and in Kenya in particular, revolve around the character of the state and how, historically, it has been deployed by various political classes. The state in postcolonial Kenya has predominantly been deployed as a 'site of eating', that is, state power has been used to secure the economic interests of the dominant political classes and to enable them to dispense patronage and political manna to their client base, almost invariably, ethnic-based constituencies. Such a state invariably appropriates state institutions and deploys them as instruments of primitive accumulation, pursuing policies and objectives which conflict with broader society interests. In the context of uneven capitalist penetration in Kenya and its tendency to engender regional (ethnic) inequalities, such contestation is bound to engender regional (ethnic) disparities which are then expressed as ethnic contests.

Thus we can argue that the ethnic clashes which have characterised much of the period of multiparty politics are not tribal conflicts in the real sense, rather, they are politically organised conflicts orchestrated to achieve short- and long-term political, and ultimately economic, advantages. I propose that an understanding of the recent electoral crisis in Kenya must be sought within an analysis that confronts the nature of political economy, forms of accumulation and the way these have informed the conduct of politics itself.

The paper is structured as follows: the introduction is followed by a brief historical sketch of the rise of authoritarian governance and institutionalised despotism in Kenya's post-colony. The third section analyses the Kibaki/ National Rainbow Coalition (NARC) regime since 2002 and the political developments leading to the 2007 elections. This section is followed by a focus on the election and its outcome, on which is based an explanation of the violence. The conclusion attempts to draw the narrative together.

\section{INSTITUTIONALISED DESPOTISM: KENYATTA AND MOI}

\section{The Kenyatta regime}

Kenya became independent in 1963, governed by a Westminster parliamentary system involving the Kenya African National Union (Kanu) and the Kenya African Democratic Union (Kadu). Kanu had won the majority of seats in the bicameral Assembly and had formed the first independent government, while Kadu settled in the opposition benches. 
The two parties had represented different combinations of class forces. Kanu was the party of sections of the indigenous embryonic capitalist class, the petit bourgeoisie and aspirant African middle classes, which, for historical reasons, consisted mainly of the Kikuyu and Luo ethnic groups. Kadu was also included in a convoluted alliance with unlikely bedfellows - a trade union movement, the Kenya Federation of Labour; the urban working class; urban traders; the Nairobi Crowd ${ }^{1}$ (Furedi 1973); the peasantry; and, more significantly, the squatter movement, which was predominantly, but not exclusively, Kikuyu. The battle between these different class forces over the post-colonial state would result, in 1966, in a split and, eventually, in the ethnicisation of political discourse and descent into authoritarian rule.

Kadu on the other hand, was an alliance of the weaker sections of similar class forces, mainly from the minority nationalities - the Nilotic ethnic groups in the Rift Valley, which call themselves the Kalenjin, sections of the Luhyia tribal groupings, and the coastal Giriamas and Swahilis of Arabic extraction (Njonjo 1977). This party lacked the political clout to compete on an equal footing in the then unfolding political space. Not surprisingly, its political programme was underpinned by the demand for majimboism (federalism).

On the first anniversary of independence, in December 1964, Kenya became a republic, with Jomo Kenyatta its first president and Jaramogi Oginga Odinga, a member of the radical wing of the party, his deputy. At the same time Kadu defections to the ruling party, which had started in 1963 with the defection of Nandi MP Jean Marie Seroney, now turned into a full-scale desertion. The result was that Kadu dissolved itself and joined the ruling Kanu, creating a de facto single-party system. This move bolstered the conservative faction within Kanu and created an environment in which the long-running ideological battle between the radicals and the conservatives in the ruling party could now be fought to its conclusion

The battle finally led to Vice-President Odinga and veteran trade unionist Bildad Kaggia breaking with Kanu in 1966 to form the opposition Kenya People's Union (KPU). The formation of the party was the culmination of a protracted battle over ideological differences which had consumed the party throughout the six years of its existence (Odinga 1966). Odinga and Kaggia were followed onto the opposition benches by 33 members of Parliament. The establishment of the opposition and the return of multiparty politics confronted the Kenyatta regime with its first serious political crisis and, in the end, exposed the authoritarian nature of the regime. The government rushed through new legislation, Amendment 2 of

1 Furedi uses the concept 'crowd' to define the urban classes which had the smallest stake in the colonial political economy. The 'crowd', like the 'sanscullote' of the French Revolution, had a limited stake in the status quo. 
Act 17 of 1966, the Fifth Amendment to the Constitution, which required that all members of the Assembly who changed parties must seek a new mandate from their constituencies (Gertzel, Goldschmidt \& Rothschild 1969).

In the 'little general election' which followed the resignation of the KPU members, Kanu won eight of the ten Senate seats to KPU's two and 12 of the 19 House seats to KPU's seven. The KPU's strength was thus reduced to Odinga's Nyanza constituency, and it was now perceived as a tribal party. This ethnicisation of the opposition party suited the ruling party and the government perfectly. Mueller (1984), however, suggests that the KPU's national presence was much stronger than its Nyanza representation might have suggested and that the state's use of repressive tools against the party may explain its eventual demise.

Kenyatta's second political crisis came in the wake of the assassination of Tom Mboya in 1969, at a time of increasing resentment of the consolidation of Kikuyu power in the economic and political spheres. At the forefront of this resentment was the Luo community, who felt marginalised in the distribution of state resources. Mboya might have remained within the Kenyatta coalition, and had been instrumental in forcing Odinga out of Kanu and government, but he retained substantial support among the Luo and, in certain quarters, was regarded as the only surviving Luo link with the government (Goldsworthy 1982). His ambition to succeed Kenyatta struck a favourable chord within certain quarters in Luoland who argued that it was not in the interest of Luos to put all their eggs in the KPU basket.

Within this context the outpouring of anger that followed his assassination in a Nairobi street can be understood. The demonstrations were largely spearheaded by the Luo community, but they nonetheless incorporated large elements of other groups within the urban areas. Nairobi, the capital, was rendered ungovernable for almost a week. Similar demonstrations took place in Mombasa and Nakuru and in Homa Bay, Mboya's home town.

The regime was shaken by Mboya's assassination as it had not been by the formation of the KPU. The resignation of a deputy president from government was, after all, part of the normal knock about of politics; the assassination of a senior minister, ruling party secretary-general and a leading contender for the presidency was an entirely different ball game. It damaged the country internationally and, more significantly, it fundamentally eroded the legitimacy of Kenyatta and his regime.

Kenyatta's response to the political challenge posed by the Mboya crisis was to invoke narrow national chauvinism and seek cover under Kikuyu ethnicity. The government organised and orchestrated an 'oathing' campaign to mobilise the Kikuyu peasantry and the Kikuyu urban sansculottes behind the Kenyatta regime. The oathings were conducted mainly by Kikuyu officials of the provincial 
administration at Gatundu, Kenyatta's Kiambu home. The oaths were designed to unite the Kikuyu ethnic group in a determination to keep the 'flag in the house of Mumbi' (Karimi \& Ochieng 1980), that is, the government to remain under Kikuyu leadership.

Kenyatta's third political crisis emanated from the assassination of the populist Nyandarua North MP and former assistant minister J M Kariuki (popularly known as JM). JM's sin, it would seem, was threefold. He was a 'Diaspora' (Rift Valley) Kikuyu whose parents, like most landless Kikuyus at the beginning of the 20th century, had migrated to Rift Valley. He had been a member of the Mau Mau movement and had been detained and was therefore not part of Kenyatta's Kiambu coalition, which held a stranglehold on political and economic institutions of the state.

Secondly, he had accumulated wealth in the first six years of independence and had used it to champion populist Kikuyu and national causes and to position himself for the Kenyatta succession. By 1973, he had built a strong populist following in the two Kikuyu districts of Nyeri and Muranga and counted among his followers such Kikuyu heavyweights as Waruru Kanja from Nyeri and Charles Rubia from Muranga.

Third, JM transcended his ethnic base and, by appealing for redistribution of land, was able to put together a populist platform nationally. Among his followers were the MP for Tinderet, the deputy speaker of the House, and several assistant ministers. As a Kikuyu he was capable of subverting Kikuyu sub-nationalism from within (Throup 1989) and thus posed the most serious political threat to the Kenyatta coalition.

What do we make of this brief summary of the Kenyatta regime? Even though Kenyatta presided over a growing economy and an expanding middle class, and allowed a small political space within which parliamentarians could make a few noises, it would seem that the most visible trademark of his regime was its refusal to accept democratic challenges to its right to rule.

From 1969 the regime displayed a growing arrogance in the use of state power for the purpose of personal accumulation and completely politicised the allocation of public resources. This predictably facilitated the consolidation of the indigenous class of capital and property, which, for historical reasons, had emerged predominantly from within the Kikuyu, particularly the powerful Kiambu faction, which directly controlled state power.

This period thus produced a more cohesive 'lootocracy', the Kiambu section of the economic elite constituting its inner cabal, and the rest, arranged in its respective pecking order. In the dying days of the Kenyatta regime, deliberate politicisation of the allocation of public resources, particularly to Kenyatta's Kiambu coalition, was clearly visible. By 1978 a powerful politico-economic class 
had emerged within this group and dominated the economy and politics. It had effectively moved from traditional areas of primitive accumulation into modern sectors of the economy - manufacturing, banking, and finance.

It is this tight control of economic and political power by a small section of the Kiambu clique that probably explains the euphoria in the early days of Moi's presidency.

\section{THE MOI REGIME AND THE RISE OF THE KLEPTOCRATS}

Moi took over the presidency in 1978, after Kenyatta's death. During his 12 years as vice-president he had observed the growing arrogance of the Kenyatta coalition at close quarters and watched as its members used state power to ascend to the commanding heights of the economy. He must have concluded that political power was more than a Cabinet office, it was the access to the key levers of the economy. But initially he was too weak to break the established Kenyatta coalition, so, in the next five years he ruled through the support of Mwai Kibaki and Charles Njonjo, finance minister and attorney general respectively in the Kenyatta regime.

The failed coup attempt of 1982 was probably the most important turning point in Moi's consolidation of power. It enabled him to dismantle Kenyatta's security apparatus and replace it with his own, though the extent of his success remains debatable. ${ }^{2}$ At the same time he brought back detention without trial, and repression once again became a pillar of political order. Finally, he could now openly assemble a ruling coalition of his own and, once this was in place, could afford to confront Charles Njonjo, Kenyatta's powerful attorney general, who had helped him to ascend the presidency. Within a year of the coup attempt Njonjo had been removed from government and the party and, following a humiliating commission of inquiry, dispatched into the political wilderness.

President Moi's new alliance was, however, a relatively weak economic class, predominantly an alliance of politicians from the areas with the least capitalist development. And, unfortunately, his rule commenced with the doubling of the oil price - which, two years later, was absorbing 50 per cent of foreign exchange earnings - and a massive fall in cash crop earnings. Thus Moi's embryonic accumulators could only assemble a capital base by looting the original looters, or, as Mutahi Ngunyi (1993) puts it, it could only be predicated on the dissolution of the already entrenched Kikuyu capital.

2 Throup 1986, for example, asserts that as late as 1986 Moi had not established hegemony over the armed forces. 
Patronage and resources came to be concentrated in Moi's own ethnic group, the Kalenjin in general, and the Tugen in particular, a process that coincided with the consolidation of his coalition in the aftermath of the coup attempt. Furthermore, Moi, like Kenyatta, politicised the allocation of public and private investments - roads, educational infrastructure, and agricultural investments were directed mainly at Moi's political constituency. The new power thus became self-consciously a Kalenjin power; institutions previously dominated by the Kikuyu were 'Kalenjinised'. Access to resources - university education, state and employment in parastatals - depended on whether one was recognised by the government as a member of the 'Kanu' tribe'.

This type of distribution of resources and the crude use of the state for primitive accumulation could only be predicated on authoritarian control. Thus the deeper it sank into kleptocracy the more authoritarian the state became. Not for nothing did Moi do away with the ethno-regional balancing act that had provided a veneer of political legitimacy and stability for the Kenyatta regime. The substitution in 1987 of the secret ballot system with queue voting was one such indication of the regime's loss of confidence in free and fair electoral contests. More importantly, however, the Moi regime fostered a kleptocratic bourgeoisie whose existence and survival depended very much on its continued access to this type of authoritarian state

\section{FROM KLEPTOCRATS TO PREDATORS}

The reintroduction of competitive elections towards the end of 1991 caused panic and tension within Moi's coalition. Convinced that they were unlikely to win democratically-conducted elections its members set about the serious business of plundering the state, gradually transforming its institutions into predatory instruments of primitive accumulation by a largely parasitic class.

The unmitigated plunder of state resources took different forms - dubious contracts, questionable purchases by government departments and parastatals, unauthorised expenditure, non-payment of duties on imported goods, the award of government lands to cronies and subsequent sales to well connected businesspersons, the sale of government houses to supporters at knockdown prices and the awarding of non-existent consultancies to dubious consultancy firms.

This was the period of the infamous Goldenberg scandal, in which a local firm, Goldenberg International, owned by an Asian businessman, Kamlesh Pattni, was allegedly paid KSh51,5-billion for non-existent gold and diamonds exports.

Such was the prevailing state of affairs when political space opened up and Kanu was replaced by the NARC coalition in 2003. 


\section{ENTER KIBAKI}

Kibaki, representing NARC, became president in 2003 on a wave of popular rejection of Moi's regime and in the most celebrated landslide victory in Kenya's electoral history. NARC was cobbled together by Kibaki's Democratic Party (DP), the late Michael Wamalwa's Ford Kenya (FORD-K), and Raila Odinga's Liberal Democratic Party (LDP).

The DP represented the hegemonic class of capital and property, which had its origins in Kenya's first independent government under Jomo Kenyatta. This was the elite of the old Nyeri bourgeoisie and its Kiambu counterparts (predominantly, but not exclusively, the Kikuyu). This group, now referred to in Kenya's political discourse as the 'Mount Kenya Mafia', remains the most powerful economic class in the country; Kenya's indigenous bourgeoisie par excellence.

While it suffered considerable setbacks under the Moi regime it was not completely wiped out and has a long experience of straddling economic and political power. Significantly, it moved quite speedily to occupy the strategic positions vacated by the Moi crowd.

Raila's LDP and, to some degree, Ford Kenya represented the traditional petit bourgeois leadership of Kenya's opposition. It lacked a firm economic base, was considerably impoverished and because its leaders had been in the political wilderness for a considerable time they had limited experience of wielding political and economic power.

The NARC coalition, far from being born out of a political ideology, was an amalgam of old and new recycled Kanu politicians glued together by common hostility to Moi to form a united front to topple Kanu and gain access to State House. Beyond that, the three major parties in the coalition had very little in common; they were a ragtag army of political opportunists on a journey to selfrenewal. Not surprisingly, their coming together as a coalition had to be spelled out in black and white in the now famous founding document, the Memorandum of Understanding (MoU), which outlined how power and the spoils of victory would be distributed within the coalition.

There is a broad consensus that Kibaki's DP reneged on the MoU's core idea of an equal partnership between the NAK and the LDP; that he failed to consult his partners about Cabinet appointments and other senior positions within the government, and that, in his distribution of the spoils, he ignored key LDP constituencies in the Nyanza, Western and Coast provinces. Furthermore, it is acknowledged that Kibaki's Mount Kenya coalition moved speedily to dispense state patronage to its constituency.

Appointments to senior government positions, parastatals, and diplomatic postings predominantly favoured Kibaki's ethnic group, and Kibaki, like Moi and 
Kenyatta before him, politicised the allocation of public and private investments - the provision of roads, educational infrastructure, and agricultural investments was directed mainly at his political constituency.

The new NARC power similarly became self-consciously a Kikuyu power; institutions previously dominated by the Kalenjin were 'Kikuyunised' and access to resources - employment by the state and in parastatals - depended on whether one was recognised by the government as a member of the Mount Kenya grouping (Mwangi 2008).

Tensions over and disagreements about the MoU were to characterise Kibaki's entire first term and form the backdrop against which the 2007 elections would take place. It is also against this background that the constitution-making process at the National Constitutional Conference (the Bomas Conference) came to play such a central role in the battle for control of the state.

At the centre of the controversy at Bomas had been the whittling away of presidential powers and the creation of an executive premier. Because of the unpopularity of the previous regime there had been a national consensus over these issues and NARC had made them a plank in its campaign platform but it became clear that, having moved into State House and, in a sense, tasted the fruits of political power, the DP faction had no interest in any constitutional reforms which might tamper with the powers of the presidency.

Thus, during the entire NARC regime the country witnessed a macabre battle over the Memorandum of Understanding through the constitutional reform process. It was a battle the Kibaki faction was unlikely to win since delegates to the conference had been appointed by the previous regime and were perceived to be loyalists of the short-lived Kanu-NDP Alliance of former president Moi and Raila Odinga.

The November 2005 constitutional referendum which had divided the ruling NARC coalition into two camps - the Banana camp (Kibaki) and the Orange camp (Raila Odinga) - and in which the government was defeated by the Orange camp, proved to be the culmination of the disintegration of the coalition. The main contentious issue was how much power should be vested in the presidency and how other political institutions might be strengthened.

Because President Kibaki had vigorously supported the new Constitution and was perceived to be attempting to entrench an authoritarian presidency many voters used the referendum as a vote of no confidence in the president. The victory of the LDP faction and its expulsion from government set the stage for the 2007 general elections and, for all practical purposes, election campaigns started in earnest at the end of the referendum.

In the run up to the elections Kibaki made two decisions with farreaching implications for their outcome. First he brushed aside the Inter Parties 
Parliamentary (IPPG) Agreement of 1997 and went on unilaterally to appoint 19 of 22 Electoral Commission of Kenya (ECK) commissioners without consulting the other political parties. This was seen as a deliberate attempt to undermine the independence of the electoral commission. Secondly, a week before the elections Kibaki appointed six judges to the Electoral Court, evidence that he was preparing to stage-manage judicial resolution of any disputes that might arise. Given that despite the judicial reforms of 2003, 12 electoral petitions against the outcome of the 2002 parliamentary elections remained unresolved, and individuals whose victories had been challenged had served a full five years, Kibaki's tampering with the electoral court on the eve of a general election raised considerable suspicion.

\section{THE OUTCOME}

More than 30 political parties contested the elections. However, the only real players were Kibaki's Party of National Unity (PNU) and the two opposition parties - Odinga's ODM and its breakaway faction, Kalonzo's ODM Kenya. The NARC, Nyachae's Ford People, the Social Democratic Party, and the Kenya African Development Union (Kadu) were insignificant players.

Quite clearly the outcome of the elections indicated the electorate's determination to challenge what was perceived as Kibaki's failure to deliver on his 2002 promises and to end 29 years of political and economic rot. It was an unambiguous rejection of five years of Kibaki's and 24 years of Moi's rule (Moi had campaigned vigorously for Kibaki).

In six of the eight provinces the PNU was rejected outright. Twenty of his 30 Cabinet ministers, including his vice-president and ministers from his Central Province backyard, lost their parliamentary seats; Raila's ODM won 99 seats to Kibaki's 37 and dominated local authority elections in all but the Central and North Eastern provinces. This was both a total rejection of Kibaki and a vote for change, since change in the presidency was perceived as absolutely necessary to redress the historical imbalances noted above.

The results, according to many observers, were a foregone conclusion once Raila succeeded in stitching together a western alliance (Nyanza, Western and Rift Valley provinces) and the Coast Province. The ODM alliance was the old NARC alliance without the Central and Eastern provinces, Central Province having swapped places with the Rift Valley Province in the old alliance.

Interestingly, the pattern of voting has not changed much. The figures for 2007, as demonstrated in the three tables below, were not very different from the patterns in 1992, 1997 and 2002. The tables below prove the point. In 1992 Moi won with 36,9 per cent of the popular vote against a combined opposition tally 
of 63,1 per cent. In 1997 Moi won again, with a marginally improved 40 per cent against the combined opposition tally of 60 per cent. In 2002 Kibaki won with 62,8 per cent compared with Uhuru Kenyatta's 31 per cent. The 2007 figures seemed to have replicated these results.

In the political realignment that took place after the break up of NARC in 2005 Raila's ODM had the big three - Luo, Luhya, and Kalenjin - with the support of the Coast, the North Eastern, and Nairobi provinces. Kibaki's PNU had the Kikuyu backing from the Central Province, while the ODM Kenya had Ukambani in the Eastern Province.

Thus there is no way the PNU could have won the presidency. The parliamentary result speaks for itself, unless, of course, there was some sort of strategic voting pattern whereby those who voted for opposition candidates in the general election chose to vote differently when it came to presidential vote - a pattern never before seen in Kenya.

Table 1

1992 Presidential votes by province

\begin{tabular}{|l|l|l|l|l|l|}
\hline & Kibaki & Matiba & Moi & Odinga & Others \\
\hline & DP & FORD A & Kanu & FORD K & \\
\hline Nairobi & 69715 & 165553 & 62410 & 75888 & $*$ \\
\hline Coast & $18 \%$ & $44 \%$ & $16 \%$ & $20 \%$ & $2 \%$ \\
\hline & 32201 & 33399 & 188296 & 42796 & $*$ \\
\hline N Eastern & 3259 & $11 \%$ & $62 \%$ & $14 \%$ & $3 \%$ \\
\hline & $5 \%$ & $11 \%$ & 46420 & 5084 & $*$ \\
\hline Eastern & 392481 & 79436 & 290372 & 13673 & $*$ \\
\hline & $50 \%$ & $10 \%$ & $37 \%$ & $2 \%$ & $1 \%$ \\
\hline Central & 373147 & 630194 & 21918 & 10668 & $*$ \\
\hline & $35 \%$ & $60 \%$ & $2 \%$ & $1 \%$ & $2 \%$ \\
\hline Rift Valley & 98302 & 214727 & 981488 & 75465 & $*$ \\
\hline & $7 \%$ & $16 \%$ & $71 \%$ & $5 \%$ & $1 \%$ \\
\hline Western & 14404 & 214060 & 219187 & 98822 & $*$ \\
\hline & $2 \%$ & $38 \%$ & $39 \%$ & $17 \%$ & $4 \%$ \\
\hline Nyanza & 51988 & 10299 & 117554 & 581490 & $*$ \\
\hline & $6 \%$ & $1 \%$ & $15 \%$ & $75 \%$ & $3 \%$ \\
\hline Total & 1035507 & 1354856 & 1927 & 903886 & \\
\hline
\end{tabular}


Table 2

1997 General election vote by province

\begin{tabular}{|l|l|l|l|l|l|}
\hline & Moi & Kibaki & Raila & Kijana & Ngilu \\
\hline & Kanu & DP & NDP K & FORD K & SDP \\
\hline Nairobi & 75272 & 160124 & 59415 & 24971 & 39700 \\
\hline & $20,56 \%$ & $44 \%$ & $16,23 \%$ & $6,82 \%$ & $10,85 \%$ \\
\hline Coast & 229084 & 50540 & 22794 & 11156 & 37600 \\
\hline & $61,05 \%$ & $13,40 \%$ & $6,07 \%$ & $2,97 \%$ & $10,02 \%$ \\
\hline N Eastern & 46121 & 11741 & 210 & 4418 & 466 \\
\hline & $73,08 \%$ & $18,60 \%$ & $0,33 \%$ & $7,00 \%$ & $0,58 \%$ \\
\hline Eastern & 368801 & 296262 & 7755 & 7009 & 33250 \\
\hline & $35,87 \%$ & $28,81 \%$ & $0,75 \%$ & $0,68 \%$ & $32,35 \%$ \\
\hline Central & 55822 & 885382 & 6812 & 3067 & 29470 \\
\hline & $5,59 \%$ & $88,73 \%$ & $0,68 \%$ & $0,31 \%$ & $2,95 \%$ \\
\hline
\end{tabular}

\begin{tabular}{|l|l|l|l|l|l|}
\hline Rift Valley & 1140409 & 343529 & 36022 & 102178 & 11340 \\
\hline & $69 \%$ & $20,90 \%$ & $2,19 \%$ & $6,22 \%$ & $0,69 \%$ \\
\hline Western & 314669 & 9755 & 13458 & 338120 & 3429 \\
\hline & $44,67 \%$ & $1,38 \%$ & $1,91 \%$ & $48,00 \%$ & $0,49 \%$ \\
\hline Nyanza & 215923 & 138194 & 519259 & 14623 & 15300 \\
\hline & $23,53 \%$ & $15,05 \%$ & $56,55 \%$ & $1,59 \%$ & $1,57 \%$ \\
\hline Total & 2445801 & 1895527 & 665725 & 505542 & 46980 \\
\hline
\end{tabular}

Source: Ajulu 1998 
Table 3

2002 Presidential Election Results

Summary Per Province - Preliminary

\begin{tabular}{|c|c|c|c|c|c|c|c|}
\hline & $\begin{array}{l}\text { Registered } \\
\text { voters }\end{array}$ & $\begin{array}{c}\text { Kenyatta } \\
\text { Uhuru } \\
\text { Muigai }\end{array}$ & $\begin{array}{c}\text { Kibaki } \\
\text { Mwai }\end{array}$ & $\begin{array}{c}\text { Nyachae } \\
\text { Simeon }\end{array}$ & $\begin{array}{c}\text { Orengo } \\
\text { James } \\
\text { Aggrey }\end{array}$ & $\begin{array}{c}\text { Waweru } \\
\text { David } \\
\text { Ngethe }\end{array}$ & $\begin{array}{l}\text { Total } \\
\text { valid } \\
\text { votes }\end{array}$ \\
\hline & & Kanu & Narc & Ford-p & SDP & CCU & \\
\hline \multicolumn{8}{|l|}{ Province } \\
\hline \multirow[t]{2}{*}{ Nairobi } & 884135 & 75635 & 279709 & 8771 & 890 & 303 & 365308 \\
\hline & & $20,704 \%$ & $76,568 \%$ & $2,401 \%$ & $0,244 \%$ & $0,083 \%$ & \\
\hline \multirow[t]{2}{*}{ Coast } & 879741 & 109706 & 219409 & 11470 & 1430 & 790 & 342805 \\
\hline & & $32,002 \%$ & $64,004 \%$ & $3,346 \%$ & $0,417 \%$ & $0,230 \%$ & \\
\hline \multirow[t]{2}{*}{$\mathrm{N}$ Eastern } & 216336 & 79004 & 33348 & 4947 & 169 & 73 & 117541 \\
\hline & & $67,214 \%$ & $28,317 \%$ & $4,209 \%$ & $0,144 \%$ & $0,062 \%$ & \\
\hline \multirow[t]{2}{*}{ Eastern } & 1734209 & 233614 & 658913 & 7188 & 3116 & 1987 & 904818 \\
\hline & & $25,819 \%$ & $72,823 \%$ & $0,794 \%$ & $0,344 \%$ & $0,220 \%$ & \\
\hline \multirow[t]{2}{*}{ Central } & 1563084 & 300222 & 680386 & 4279 & 1383 & 1947 & 988217 \\
\hline & & $30,380 \%$ & $68,850 \%$ & $0,433 \%$ & $0,140 \%$ & $0,197 \%$ & \\
\hline \multirow[t]{2}{*}{ Rift Valley } & 2415555 & 734932 & 623343 & 35972 & 3740 & 1616 & 1399603 \\
\hline & & $52,510 \%$ & $44,537 \%$ & $2,570 \%$ & $0,267 \%$ & $0,115 \%$ & \\
\hline \multirow[t]{2}{*}{ Western } & 1202104 & 126483 & 468037 & 8295 & 3195 & 1545 & 607555 \\
\hline & & $20,818 \%$ & $77,036 \%$ & $1,365 \%$ & $0,526 \%$ & $0,254 \%$ & \\
\hline \multirow[t]{2}{*}{ Nyanza } & 1555968 & 63572 & 522121 & 227363 & 9630 & 1115 & 823801 \\
\hline & & $7,17 \%$ & $63,380 \%$ & $27,599 \%$ & $1,169 \%$ & $0,135 \%$ & \\
\hline $\begin{array}{l}\text { National } \\
\text { total }\end{array}$ & 10451150 & 1723168 & 3485266 & 308285 & 23553 & 9376 & 5549648 \\
\hline $\begin{array}{l}\% \text { votes } \\
\text { won }\end{array}$ & & $31,050 \%$ & $62,802 \%$ & $5,555 \%$ & $0,424 \%$ & $0,169 \%$ & \\
\hline
\end{tabular}

Source: Electoral Commission of Kenya December 2002 
The outcome of the 2007 elections was the result of changing alliances and a newfound confidence in the ballot box. I have argued elsewhere (Ajulu 2008) that for more than four decades Kenyans had been used to rigged elections, and had lost faith in electoral politics.

The historic 2002 general elections changed all this. The impact of the 2002 elections was a decisive shift in the old scenario and restored some faith and confidence in the ballot box. The Kenyan electorate became increasingly confident as the 2007 elections approached. The constitutional referendum of 2005, which had handed Kibaki a humiliating 'No' vote, seemed to have reinforced this confidence - the belief that the people could actually vote out unwanted leaders. And with this renewed confidence came the hope that popularly elected leaders would address the historical injustices revolving around ethnic tensions fostered by regional inequalities, economic marginalisation and unmitigated poverty.

\section{SO WHY SUCH VIOLENCE?}

How do we explain the violence of the reaction to Kibaki's illegitimate extension of his tenure? The anger seen in the aftermath of his swearing in stemmed from a widespread feeling of having been cheated out of change, the hope of which had brought people to the polling stations on 27 December in greater numbers than ever before in Kenya's electoral history.

For some the sense of frustration about the result ignited all the grievances of the past four decades in relation to poverty, the need for land reform, unemployment, perceived ethnic arrogance and other issues. While the nature of the violence shocked many observers and political analysts only the scale was unique - such ethnic confrontations have been part of political contestation ever since the country gained its independence.

One of the enduring legacies of Kenyan politics is the use of ethnicity as a medium of political mobilisation and contestation of resources. Although it was basically a creation of settler colonialism, after independence, for reasons I have analysed elsewhere in more detail (Ajulu 2001), ethnicity has become the most important and effective instrument of political mobilisation.

Historically political elites have mobilised and politicised ethnic or religious identities in order to achieve certain political and economic objectives. It must be pointed out, however, that such mobilisation only takes place in certain circumstances. In 'normal' conditions ethnic identity does not play an important role in the interaction between different groups and different ethnic groups have lived together in various parts of Kenya for decades without resorting to solving their differences through violence. Only at certain specific historical conjunctures does the need arise to mobilise ethnic bonds. The aim may be to defend the identity 
of a group from a perceived attack by other groups, to contest the distribution of resources, or simply to promote an already dominant group. Either way, the relationship between ethnic mobilisation and conflict is clear. At one end there may be no conflict at all, at the other the potential for conflict is enormous. Kenya has experienced four such conjunctures.

The first of these was the battle for power during the run up to the independence election in 1963 between the two parties of Kenya nationalism, Daniel arap Moi and Ronald Ngala's Kenya African Democratic Union (Kadu) and Jomo Kenyatta and Oginga Odinga's Kenya African National Union (Kanu. Kadu was the party of what Bennet (1957) called the 'alliance of the pastoralist tribes' - Kalenjin, Masai, Turkana, Samburu' and the Giriama of the Coast and sections of the Luhyia of Western Kenya - while Kanu had the support of the two major ethnic groups - the Luo and Kikuyu.

So intense was the battle that the minority parties opted for ethnic separatism fearing that the dominant ethnicities - the Luo and Kikuyu - would run roughshod over the minorities. At the centre of these fears were post-colonial land dispensation and the distribution of other resources - jobs, infrastructure, and so on. It was in these circumstances that a federalist dispensation ('majimboism') was imposed on Kenya by the Lancaster Agreement that ushered in independence.

Federalism however was not Kadu's creation. It had its origins in 1954 with the formation of the whites-only Federal Independent Party (FIP), which had sought to protect the 'White Highlands' from African control by adopting a federal platform. In 1958 the FIP became the Progressive Local Government Party (PLGP): the rhetoric had changed but the objectives remained the same. The party advocated strong local governments, with powers over local taxation and expenditure. Kadu only adopted the 'majimbo' idea in 1961, and only when it had become clear that, together with its allies, Michael Blundell's New Kenya Party (NKP) and the Kenya Indian Congress (KIC), which then controlled the transition government, were unlikely to win the 1963 election and assume control of an independent unitary state. Majimboism was launched under the slogan 'Regionalism or Civil War' (Sanger \& Nottingham 1964).

It was in these circumstances that the Kalenjin political elite began mobilising on a platform of Kalenjin ethnicity. William Murgor, then parliamentary secretary to the Defence and Internal Security department in the transitional government, invited fellow Kalenjin tribesmen to sharpen their spears and wait for the sound of his whistle for the start of war to drive non-Kalenjins out of Rift Valley. Arap Moi, then chairman of Kadu, vowed to shed his blood to ensure that regionalism was written into the independence constitution (Athieno-Odhiambo 1998).

Thus, from 1961, ethnic clashes swept through the Rift Valley Province. The Kikuyu, Luhyia and other ethnic groups which had lived in the area for years 
were labelled foreigners. Their houses were burnt and many became refugees - a situation that was to be repeated in the elections of 2002 and 2007. In the Coast Province Kadu's Sammy Omari popularised the slogans Wabarra Kwao (Up country people back to their own homelands!) and Kila mtu Kwao (Every person to his or her own homeland!). These slogans had, of course, to be backed up by violence.

The second bout of ethnic mobilisation came in the wake of the assassination of Tom Mboya in 1969. As stated above Mboya was the victim of internal rivalry within the ruling Kanu party to succeed Kenyatta. His assassination, however, came at a time when a majority of ethnic groups increasingly resented the consolidation of economic and political power by the hegemonic Kikuyu ruling elite and thus threatened to unite the Luo and other ethnic groups behind Odinga against the Kikuyu. The possibility of a resurgence in Odinga's political fortunes struck panic within the Kiambu coalition, resulting in the oathing campaign detailed above. ${ }^{3}$

It was not the small hegemonic elite that was threatened by the crisis, which it had brought upon itself; rather, its members argued, the entire Kikuyu ethnic group was under threat and must take the oath in readiness to defend the House of Mumbi, the eponymous founder of the Kikuyu tribe. As Ngunyi (1993) puts it:

... to protect its stakes and maintain the regime's inner stability ... the 'Family' quickly constituted a Kikuyu brigade charged with the tacit responsibility of mobilizing the entire Kikuyu community to protect the 'motherland' against the 'enemy' ... The brigade was also responsible for administering to the community an oath of loyalty to the House of Mumbi and vowing by the oath to ensure that the Presidency never leaves the 'tribe'.

The third use of ethnic mobilisation came in the wake of the assassination of JM in 1975, an event that was to divide the Kikuyu ethnic group down the middle, isolating Kiambu from Muranga, Nyeri, and the 'Diaspora' Kikuyu. Now the context of ethnic mobilisation changed. This time round, the Kiambu Kikuyu took oath to prevent the piki piki (the presidential motor cycle outriders) from crossing the Chania River, the boundary between Kiambu and the neighbouring Kikuyu District of Muranga.

The reintroduction of competitive elections in 1991 was the fourth time ethnic mobilisation was used and marked a return of ethnic conflict to the Rift Valley Province. Once again it was the old minority coalition - the Kalenjin, Maasai

3 See, for example, Ngunyi (1993). 
Turkana and Samburu (Kamatusa), now under the umbrella of Kanu, which resorted to ethnic separatism, publicly calling on their brethren to commit acts of violence against ethnic groups which were perceived not to support the party.

In the run up to the 1992 elections the Nakuru Kanu district chairperson, Wilson Leitich, is reported to have instructed Kanu youth wingers to patrol the streets with knives, ready to chop off the fingers of anyone who showed the twofinger multiparty salute. He also instructed his youth wingers to confiscate trading licences from multiparty advocates and take them to the Kanu office (Africa Watch 1991, pp 49-50; Daily Nation 10 June 1990).

As in the early 1960s politicians instituted 'ethnic cleansing' in Rift Valley and throughout the bordering areas, leading to the removal of what they called Madoadoa (islands of non-Kalenjin groups). Their ultimate objective was stated bluntly: '... with the introduction of multi-party system the survival of the smaller ethnic groups is threatened and the only way to safeguard their interests was through this type of ethnic separatism' (Kenya Times 20 May 1993).

In the run up to the 1997 election a savage war of annihilation broke out in the Coast Province at a time when Kanu had lost the political initiative to a section of the opposition and its allies within the National Convention Assembly and it increasingly appeared that constitutional reform would be instituted which would 'level the playing field'. Violence erupted in the province, with attacks on Likoni police station on Mombasa mainland. It is widely held that once again persons high up in the government were responsible for organising, funding, and orchestrating the violence.

\section{CONCLUSION}

The outburst of violence and ethnic mobilisation that followed the 2007 election can be set against this background. Kibaki's theft of the election came at a point when a majority of ethnic groups increasingly resented the consolidation of economic and political power by the hegemonic Kikuyu ruling elite.

Kibaki's inner cabal (the Mount Kenya Mafia), like that of Kenyatta's 'Kiambu Bourgeoisie' or the 'Family' 38 years earlier, came exclusively from the Central Province, straddled economic and political power, dominated the economic, bureaucratic, diplomatic and corporate sectors, and displayed absolute arrogance in the use of its powers. Voters believed that a change in the presidency was absolutely necessary to redress the historical imbalances referred to above.

The recent upheavals in Kenya teach us a number of lessons. One is that elections cannot be separated from the existing political situation. A country rent by sharp divisions over poverty and the distribution of power and structured 
by battles over resources cannot possibly hold free and fair election however independent their electoral institutions.

Finally, a government which fails to include all sectors of society is likely to go the Kenyan way. Historically Kenya has managed to paper over the cracks but we now understand that beneath the semblance of stability lie serious problems which must be addressed urgently if we are not to see a return of this type of violence at the next elections.

\section{- REFERENCES -}

Africa Watch. 1991. Kenya: Taking Liberties. New York.

1993. Divide and Rule: State Sponsored Ethnic Violence in Kenya. New York and Washington.

Ajulu, R. 1993. 'The 1992 Kenya General Elections: A Preliminary Assessment'. Review of African Political Economy 56.

1998. 'Kenya's Democracy Experiment: The 1997 Elections'. Review of African Political Economy 76.

2001. 'Kenya: One Step Forward, Three Steps Back'. Review of African Political Economy 28(88).

2008. Kenya's 2007 General Elections: Anatomy of an Electoral Crisis. Midrand: Institute of Global Dialogue.

Atieno-Odhiambo, E. 1993. 'The Agrarian Question, Ethnicity and Politics in Kenya, 1955-1993. Paper presented at a conference on Ethnicity, Identity and Nationalism in South Africa: Comparative Perspectives, Rhodes University, 20-24 April.

1998. 'Hegemonic Enterprises and Instrumentalities of Survival: Ethnicity and democracy in Kenya'. Paper presented at the Africa Philosophy Colloquium: Reconceptualising Africa's Governance, University of Louisville, Kentucky, 2-4 April.

Bennet, G. 1957. Kenya, A political History: The Colonial Period. Oxford: Oxford University Press.

Gertzel, C J, M Goldschmidt \& D Rothschild. 1969. Government and Politics in Kenya. Nairobi: East African Publishing House.

Goldsworthy, D. 1982. Tom Mboya, The Man Kenya Wanted to Forget. London: Heinemann.

Gibbon, P (ed). 1995. Markets, Civil Society and Democracy in Kenya. Uppsala: Nordiska Afrikainstitutet,

Kanyinga, K. 1994. 'Ethnicity, Patronage and Class in Local Arena: High and Low Politics in Kiambu, Kenya, 1982-92'. In P Gibbon (ed). The New Local Politics 
in East Africa, Research Report no 95. Uppsala: Scandanavian Institute of African Studies.

Karimi, J \& P Ochieng. 1980. The Kenyatta Succession. Nairobi: TransAfrica Books Distributors.

Mueller, S. 1984. 'Government and Opposition in Kenya, 1966-1969'. Journal of Modern African Studies 22(3).

Muigai, G. 1995. 'Ethnicity and the Renewal of Competitive Politics in Kenya'. in H. Glickman (1995) (ed), Ethnic Conflict and Democratization in Africa. Atlanta: The African Studies Association Press.

Mwangi, O G. 2008. 'Political Corruption, Party Financing and Democracy in Kenya'. Journal of Modern African Studies 46(2).

Njonjo, A. 1977. 'The Africanisation of the "White Highlands": AStudy in Agrarian

Class Struggles in Kenya'. Unpublished PhD thesis, Princeton University.

Ngunyi, M C. 1993. Interpreting Political Liberalism in Kenya. Copenhagen:

Scandinavian Institute of African Affairs and Centre for Development Research.

Nyong'o, P A. 1989. 'State and Society in Kenya: The Disintegration of the Nationalist Coalition and the Rise of Presidential Authoritarianism, 196378'. African Affairs 88 (351).

Ochieng, W R. 1995. 'The Kenyatta Era: Structural and Political Changes'. In B A Ogot \& W R Ochieng (eds). Decolonization and Political Independence in Kenya. London, Nairobi and Athens, Ohio: James Currey, East African Educational Publishers and Ohio University Press.

Odinga, J O. 1966. Not Yet Uhuru, London: Heinemann.

Oyugi, W. 1997. 'Ethnicity in the Electoral Process: The 1992 General Elections in Kenya'. African Journal of Political Science 2(1).

Throup, D. 1989. 'The Construction and Deconstruction of the Kenyan State'. In M Schartzberg (ed). The Political Economy of Kenya. New York: Praeger. 1993. 'Elections and Political Legitimacy in Kenya'. Africa 63(3).

National Christian Council of Kenya (NCCK). 1992. The Cursed Arrow: Contemporary Report on the Politicized Clashes in Rift Valley, Nyanza, and Western Provinces. Nairobi. 1992. Report on Ethnic Clashes: Task Force Appointed by Inter-Parties Symposium. Nairobi.

\section{Newspapers}

Kenya Times 20 May 1993

Daily Nation 10 June 1990 


\title{
THE LEGAL FRAMEWORK OF THE GNU AND THE DOCTRINE OF THE SEPARATION OF POWERS
}

Implications for Kenya's National Legislative Assembly*

\author{
Korwa G Adar
}

Korwa Adar is Research Director of the Africa Institute of South Africa, Pretoria e-mail: Kadar@ai.org.za; korwagombe@gmail.com; korwagombe@yahoo.com

\begin{abstract}
The central theme of this study is that the formation of the coalition government has undermined the sanctity of the doctrine of separation of powers, is inconsistent with democratic principles, and, more particularly, undermines the right of popular sovereignty exercised by the electorate on 27 December 2007 in conformity with the Constitution and constitutionally established electoral laws. The National Accord and Reconciliation Act which established the government of national unity (GNU) has put in place a unique legal regime in Kenya's post-independence history. In many respects, while Kenya has a multiparty state system it currently operates like a de facto one-party state. The dominant political parties, namely, the Party of National Unity (PNU) and the Orange Democratic Movement (ODM) and their party affiliates are the contracting parties to the agreement, leaving the legislative assembly without an effective official opposition party to check the potential excesses of the executive branch of government. This anomaly is further aggravated by the fact that the third-largest political party, the ODM-Kenya, is an affiliate of the PNU.
\end{abstract}

\section{INTRODUCTION}

The disputed presidential election results of 27 December 2007 announced by the chairman of the Electoral Commission of Kenya (ECK), Samuel Kivuitu, triggered violence and the deaths of almost 1500 people and left more than 350000 internally 
displaced people (IDPs) and nearly 100000 refugees (Waki Report 2008, p 308; Kriegler Report 2008, p 3). ${ }^{1}$

Kivuitu failed in his constitutional responsibility to, among other things, 'reassure voters with regard to the secrecy and integrity of the ballot' (Kenya 1998a, Fourth Schedule, s 6(k)(l)). The violence rekindled the decades-old delicate and contentious question of land, an issue which has never been comprehensively addressed. The Commission of Inquiry into the Illegal/Irregular Allocation of Public Land (2004a; b; c) appointed by President Mwai Kibaki in 2003 submitted its report in 2004, yet those implicated in the report have not yet been charged.

It also exposed land-driven ethnocentrism, which, historically, has been encouraged and instigated by political leaders (Adar 1998). The underlying failure of the electoral process is the result of a lack of transformative leadership, particularly at presidential level. More specifically, the underlying constraint to a constitutionalism which would lead to the extension and consolidation of democracy is the fact that power is skewed in favour of the presidency, a problem which had undermined the doctrine of the separation of powers ever since independence.

The National Accord and Reconciliation Act brokered by former United Nations Secretary-General Kofi Annan, former Tanzanian President Benjamin Mkapa and Graça Machel, one of whose objects was to find an amicable solution to the impasse that had led to the violence, paved the way for the establishment of a grand coalition government (GCG) or government of national unity (GNU) negotiated by the Orange Democratic Movement (ODM) and the Party of National Unity (PNU). Figure 1 shows that the ODM enjoys a comfortable majority in Parliament, nearly twice as many seats as those held by the other parties combined. The Act, passed in March 2008, established a new legal framework of separation of powers which is unique in Kenya's independence history.

1 This study is not about the 27 December 2007 general elections per se, a subject which is examined extensively elsewhere. 
Figure 1

Members of Parliament elected in the 2007 general elections

\begin{tabular}{|c|c|c|c|c|c|c|c|}
\hline Party & $\begin{array}{c}\text { Total } \\
\text { number of } \\
\text { candi- } \\
\text { dates }\end{array}$ & $\begin{array}{c}\text { Female } \\
\text { candi- } \\
\text { dates }\end{array}$ & $\begin{array}{l}\text { Male } \\
\text { candi- } \\
\text { dates }\end{array}$ & $\begin{array}{l}\text { Number } \\
\text { of elected } \\
\text { female } \\
\text { candi- } \\
\text { dates }\end{array}$ & $\begin{array}{l}\text { Number } \\
\text { of elected } \\
\text { male } \\
\text { candi- } \\
\text { dates }\end{array}$ & $\begin{array}{c}\text { Total } \\
\text { number } \\
\text { of MPs in } \\
\text { Parliament }\end{array}$ & $\begin{array}{l}\text { \%of repre- } \\
\text { sentatives } \\
\text { in } \\
\text { Parliament }\end{array}$ \\
\hline ODM & 190 & 9 & 181 & 6 & 93 & 99 & $48 \%$ \\
\hline PNU & 135 & 12 & 123 & 4 & 39 & 43 & $21 \%$ \\
\hline $\begin{array}{l}\text { ODM- } \\
\text { Kenya }\end{array}$ & 133 & 15 & 118 & 0 & 16 & 16 & $8 \%$ \\
\hline KANU & 91 & 2 & 89 & 1 & 13 & 14 & $7 \%$ \\
\hline $\begin{array}{l}\text { Safina } \\
\text { Party }\end{array}$ & 88 & 4 & 84 & 0 & 5 & 5 & $2 \%$ \\
\hline $\begin{array}{l}\text { NARK } \\
\text { Kenya }\end{array}$ & 57 & 5 & 52 & 0 & 4 & 4 & $2 \%$ \\
\hline $\begin{array}{l}\text { National } \\
\text { Rainbow } \\
\text { Coalition }\end{array}$ & 74 & 18 & 56 & 1 & 2 & 3 & $1 \%$ \\
\hline $\begin{array}{l}\text { Forum } \\
\text { for the } \\
\text { Restora- } \\
\text { tion of } \\
\text { Democ- } \\
\text { racy for } \\
\text { the } \\
\text { People }\end{array}$ & 45 & 2 & 43 & 0 & 3 & 3 & $1 \%$ \\
\hline
\end{tabular}

Source: Electoral Commission of Kenya (2008) 
NOTE:

1. Democratic Party of Kenya (DP), Chama Cha Uzalendo (CCU), Party of Independent Candidates of Kenya (Pick), New Ford Kenya, Sisi Kwa Sisi Party of Kenya (SKSPK) each won 2 seats while the Kenya National Democratic Alliance (Kenda), Kenya African Democratic Union (Kadu), Mazingira Greens Party of Kenya (MGPK), Forum for the Restoration of Democracy (Ford)-Kenya, Forum for the Restoration of Democracy (Ford)-Asili, National Labour Party (NLP), Kenya African Democratic Union (Kadu)-Asili, United Democratic Movement (UDM), People's Party of Kenya (PPK), and People's Democratic Party (PDP) each won 1 seat.

2. Orange Democratic Movement (ODM) affiliates: National Rainbow Coalition (NARC) and United Democratic Movement (UDM).

3. Party of National Unity (PNU) affiliates: Democratic Party (DP), Ford-Kenya, Ford-People, Kanu, NARC-Kenya, New Ford-Kenya, Shirikisho and 20 other parties operating as a single party (see, Party of National Unity 2007, PNU Manifesto 2007, p 5).

The GNU has put in place a new legal regime, with important political implications, particularly with respect to the role and effectiveness of Kenya's national legislative assembly as the main watchdog over the excesses of the executive and as the law-making organ of the state.

Apart from the post-electoral debacle and the violence that ensued, the 2007 elections were among the most peaceful held in the country since the repeal in 1991 of s2A of the Kenyan Constitution, which re-introduced multipartyism (Adar 2008). The multiparty elections held in 1992 and 1997, for example, were plagued with high levels of violence prior to, during and after the elections, claiming nearly 2000 lives and creating more than 300000 IDPs and 300000 refugees (Kenya Human Rights Commission 1998; National Council of Churches, Kenya 1992a; 1992b; Solomon 1993). Responding to intense national and international criticism then-President Moi appointed Justice A M Akiwumi to head a judicial commission with a mandate to investigate the ethnic clashes (Kenya 1999, pp iii-iv).

To my knowledge none of the officials adversely implicated in the report has been charged and it remains to be seen whether those implicated by Justice Philip Waki's Commission of Inquiry into Post-Election Violence (the Waki report) or Judge Johann Kriegler's Independent Review Commission (the Kriegler report) will face justice.

The central purpose of this study is to explore the conceptual and theoretical meaning of the doctrine of separation of powers and its relevance to the structure and functions of the legislative assembly and the GNU in Kenya. It proceeds from 
the thesis that the formation of the coalition government by the Kenyan political leaders is inconsistent with democratic principles and undermines the sanctity of the doctrine of separation of powers and, more particularly, the right of popular sovereignty exercised by the electorate on 27 December 2007 in conformity with the Constitution and constitutionally established electoral laws.

Popular sovereignty, individual liberty and fundamental rights prescribed in the Constitution are vested in the ballot box and the state has the cardinal responsibility and custodial duty to facilitate, uphold, protect and promote these virtues.

The paper is divided into four parts. Part one puts into perspective the theoretical and conceptual meaning of the doctrine of separation of powers, with a special focus on Kenya. Part two explores the trajectory of the doctrine of separation of powers as it has evolved in Kenya over the years since independence and compares the application of the doctrine by the administrations of presidents Kenyatta, Moi and Kibaki. Part three explores the legal framework established by the National Accord and Reconciliation Act and its impact on the doctrine of the separation of powers while part four examines the doctrine with a special focus on the National Assembly within the framework of the GNU.

\section{SEPARATION OF POWERS: A THEORETICAL AND CONCEPTUAL FRAMEWORK}

The doctrine of the separation of powers presupposes the existence of three main branches of government, namely, executive, legislature, and judiciary, each of them vested with constitutional powers. Specifically, the doctrine provides for a system of checks and balances, with powers clearly vested in each institution by the Constitution. Inherent in the concept of separation of powers is that power should not be centralised and accumulated in one branch of government and that the role of each branch should be strengthened and enhanced. This is not to argue that the doctrine implies rigidly constituted constitutional structures, rather it is associated with the structural relationship of the three institutions. ${ }^{2}$

Separation of powers denotes power-sharing arrangements and responsibilities conferred on the three branches of the government (trias politica) by the Constitution with the object of preserving and promoting good governance and preventing tyranny (Ackerman 2000, pp 640-2; Labuschagne 2004; Barber 2001).

2 For a detailed analysis of the historical evolution of the concept of the separation of powers see Labuschagne 2004, pp 86-7; Rautenbach \& Malherbe 1996. 
One of the inherent objects of the doctrine is to preserve and promote democracy and to entrench professional competence and fundamental rights (Ackerman 2000, p 640). In democratic societies, and emerging ones such as Kenya, governments are elected to, among other things, preserve and promote these constitutional arrangements. In exercising their constitutional rights in any elections the electorates vest plenary law-making authority on legislators through the electoral process, thus promoting the virtues of the separation of powers. As La France (1989, p 30) argues, 'No law or rule is legitimate unless it rests directly or indirectly on the consent of the people.' Fundamentally, the separation of powers can be conceived as a doctrine of democratic responsibility and functional specialisation (Ackerman 2000, p 691). In other words, the trias politica constitutional structure provides for institutionalised checks and balances in government, the object of which, at least in theory, is to preserve the freedom and rights of citizens (Ely 1980). The normative principles associated with the concept since the time of its main advocates, John Locke and Baron de Montesquieu, are fourfold (Labuschagne 2004, p 87). They include the trias politica, the separation of personnel functions, separate functions, and checks and balances.

Inherent in these principles is the fundamental rights of citizens, largely entailed in the concept of democracy. The structural and functional responsibilities vested in the executive, the legislature, and the judiciary as well as their practical application vary from country to country. As Wade \& Phillips (1979, p 42) observe, 'It is not always easy or indeed possible to determine under which head a particular task of government falls'. The overlap leads to a fusion of power in a situation in which the president exercises executive and legislative authority and where the Cabinet doubles as legislator, as in the case of Kenya. In many ways this arrangement has the potential to undermine the spirit of the doctrine of separation of powers, which envisages adherence to effective checks and balances (Labuschagne 2004, p 99). The debate about the doctrine takes place between advocates of pure and those of partial theory.

Advocates of pure theory suggest that a complete separation is the most viable option because the established institutional structures contain specific constitutional mechanisms for restraining the excesses of the state, that is, strict delineation encourages separate but equal institutional structures (Vile 1998). An individual or agency should not hold office in more than one organ of state.

In many respects, institutionalised separate arrangements would pave the way for identifying failures and successes within the specific organs of the state and would encourage professionalism. With such arrangements none of the organs would be able to grow stronger than the other two.

Partial theory advocates, on the other hand, stress the importance of entrenching checks and balances which allow for overlap and institutional conflict 
(Barendt 1995; Jennings 1959). The incorporation of institutional conflict into the Constitution, partial theorists argue, has the potential to restrain the actions of the state and, by extension, to protect the rights and liberties of individuals. These distinctions vary from country to country according to the circumstances that inform the development of a constitution.

There are, however, certain assumptions that underly both the pure and partial theories of the separation of powers. Firstly, they opine that it is possible to isolate specific powers that fall within the ambit of the three branches of government; Secondly, they argue that 'there is a natural connection between these powers and the corresponding state institution' (Barber 2001, p 60).

In Kenya the dominance of the executive over Parliament and the judiciary, which has had an adverse effect on the structure and functions of the separation of powers, has historically been accomplished in some of the following ways - constitutional amendments (Okondo 1995; Ojwang 1976); presidential style of leadership (Throup \& Hornsby 1998); retention of colonial laws in the constitution (Kenya 1997a;1997b;1998b); and the establishment of the 2008 GNU.

The Constitution also vests other powers in the president and these are critical to understanding the relationship between the executive, the legislature and the judiciary. Apart from appointing the vice-president, the Cabinet and assistant ministers, who are members of Parliament, the Constitution also empowers the president to appoint judges (Kenya 2001). The contentious issue in this regard is the influence of the executive over the judiciary, which has been a feature in Kenya over the years (International Bar Association 1996; RFK Memorial Center 1992; ICJ 1998).

The fear of the influence of the executive over the judiciary was behind the ODM's reluctance to seek legal redress to settle the 2007 presidential election dispute. The negotiations to resolve the impasse over the election began after Chief Justice Evans Gicheru had sworn in Mwai Kibaki as president. While s62 of the Constitution confers tenure on judges of the High Court, s62 (4) stipulates that 'a judge of the High Court shall be removed from office by the President if the question of his removal has been referred to a tribunal', members of which are appointed by the president (Kenya 2001). Section 25(1), on the other hand, gives the president more powers over the tenure of employees of the state, stating, in part: 'save in so far as may be otherwise provided by this Constitution or by any other law, every person who holds office in the service of the Republic of Kenya shall hold that office during the pleasure of the president'.

Read together ss 62 and 25 clearly vest more constitutional powers in the executive than in the judiciary, whose members are public servants.

The next part of this paper examines Kenya's independence within the context of the models of the doctrine of separation of powers. 


\section{SEPARATION OF POWERS AND ITS APPLICATION IN KENYA, 1963-2008: A SYNOPSIS}

The post-independence Constitution, which provided for a bicameral legislature consisting of an upper house (Senate) and a lower house (House of Representatives) was a compromise between advocates of a unitary state system (led by Kanu) and those who favoured majimboism (Swahili for federalism or provincial self-government - led by Kadu. The majimbo model did not withstand the test of time or the power of the executive (Kyle 1999; Ojwang 1976). By 1965 most members of opposition political parties such as Kadu and the African People's Union had joined the ruling party, Kanu, culminating into the gradual dissolution of the opposition as well as the Senate as a legislative body. As Figure 2 indicates this marked the beginning of the fusion of powers and, by extension, executive dominance.

Part 3, s23(1) of the Constitution provides that 'the executive authority of the government of Kenya shall vest in the President and, subject to this constitution, may be exercised by him either directly or through officers subordinate to him' (Kenya 2001). Presidents Kenyatta (1964-1978), Moi (1978-2002), and Kibaki (2002- ) have been reluctant to devolve the power of the presidency through comprehensive constitutional reforms, in effect institutionalising the fusion of powers within the executive at the expense of a decentralised separation of powers.

Mwai Kibaki, who ascended to the presidency in 2002 promising to overhaul the post-colonial constitution within 100 days if NARC took over the leadership, completed his first term in office (2002-2007) without fulfilling his party's commitment in this regard.

As Figure 2 indicates, the de facto (1965-1966 and 1969-1982), the de jure (1982-1991) and the multiparty (1963-1964, 1966-1969 and 1992-) state systems fall into what would best be characterised as decentralised, fusion of powers-cumcentralised, and fusion of powers-cum-mixed models of separation of powers. Admittedly, there is no clear-cut delineation of powers in relation to the functions of the executive, the legislature and the judiciary. In Kenya, for example, the president and the Cabinet ministers are also elected members of Parliament.

\section{DECENTRALISED MODEL OF SEPARATION OF POWERS, 1963-1964}

The post-independence opposition political parties in the House of Representatives and the Senate played a key role in restraining the excesses of the executive. In 1963, for example, the Senate defeated the request by the Kenyatta 


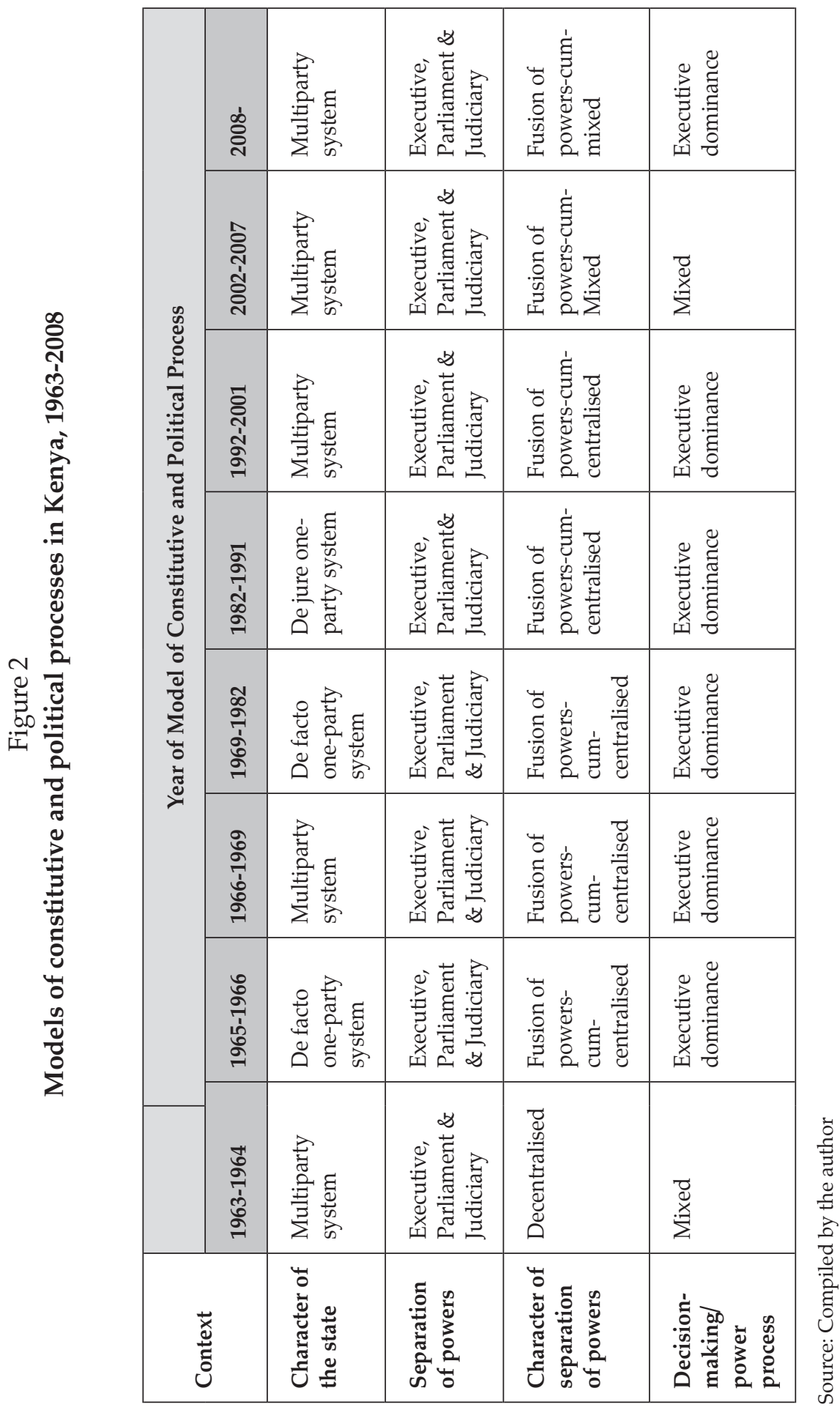


administration to authorise emergency powers to be imposed in the Northern Frontier District (NFD), a region which involved Kenya in an internal war against Somali shiftas (bandits).

The Senate, led by Kadu, argued against the emergency Bill because, in the view of the opposition legislators, it would empower the executive to operate outside the framework of the Constitution, limiting the role of the legislature. In the end the Senate, persuaded by the Minister for Justice and Constitutional Affairs, Tom J Mboya, did, in fact, support the emergency Bill (Kenya 1963, cols 25-32; Adar 1994, p 67). However, this attempt to exert the separation of powers lasted only briefly and separation is yet to be reintroduced and institutionalised.

\section{FUSION OF POWERS-CUM-CENTRALISED MODEL OF SEPARATION OF POWERS \\ 1965-2001}

As a result of the difficulties the government faced in the National Assembly the power to declare a state of emergency was entrenched in the executive branch of government during both the de facto and the de jure one-party state regimes (Kenya 1983, Art 127). It was not until the introduction of multiparty politics in 1991 that Article 127 was repealed by an Act of Parliament in 1992.

The dominance of the executive over the judiciary and the legislature has, for most of the independence period, transformed Parliament into a rubber stamp. During much of Moi's presidency Kanu and the state solidified their symbiotic relationship, with the executive branch as the driving force (Adar 1999; Nowrojee 1992; Kuria 1995). The enactment of the Interparty Parliamentary Group (IPPG) agreement as law in 1997 and 1998, which, inter alia, introduced electoral laws consistent with a multiparty system and repealed some of the colonial laws, did not prevent the Moi administration from exercising its executive functions outside the framework of the Constitution, undermining the spirit of the doctrine of separation of powers for much of the time between 1992 and 2001 (Kenya 1997b;1998a).

As Figure 2 shows the periods 1965-1966, 1966-1969, 1969-1982, 1982-1991, and 1992-2001 exhibited what I call fusion of powers-cum-centralised model of separation of powers.

\section{FUSION OF POWERS-CUM-MIXED MODEL OF SEPARATION OF POWERS 2002-PRESENT}

The drive for comprehensive constitutional reform that swept NARC into power in 2002, I would argue, brought into the Legislative Assembly proactive 
parliamentarians who championed, albeit with limitations, the cause of the adoption of a number of broad-based national policies, one of which was the conclusion of a people-centred comprehensive draft constitution in 2004 also known as the Bomas draft (Kenya 2005). This period was characterised by what would best be described as fusion of powers-cum-centralised separation of powers. The intransigence of President Kibaki about adopting and implementing the new draft constitution led to a number of members of Parliament, some of them Cabinet Ministers, resigning from NARC to form the ODM (ECK 2006; Adar 2008).

The proposed draft constitution, the details of which are outside the scope of this study, would, if adopted, put in place a complete new legal regime, particularly with respect to institutionalisation of the doctrine of the separation of powers. ${ }^{3}$ It provides for a clear devolution of powers as well as the protection of the rights of the people. The preamble contains the words 'We, the people of Kenya', a vision that is elaborated on in Chapter One, with the concepts of the 'sovereignty of the people' and the 'supremacy of the constitution' as the underlying functional, operational, and statutory principles (Kenya 2005). However, one of the shortcomings of Kenya's independence history is that the 'country's entire legal framework does not provide for any definitive, substantive or procedural essentials of official opposition' (Kenya 2008a).

\section{THE LEGAL FRAMEWORK OF THE GNU AND THE SEPARATION OF POWERS: A CONTEXTUAL ANALYSIS}

The fact that the coalition government was negotiated prior to the conclusion of the electoral process and the release of the outcome of the presidential election before all the votes had been counted puts into question the political legitimacy of the GNU.Section 40(2)(a) of the Presidential and Parliamentary Elections Regulations in the National Assembly and Presidential Elections Act provides that the ECK 'shall in the case of a presidential election, whether or not forming part of joint election, hold the certificate until the results of that election in every constituency have been received and thereafter publish a notice in the Gazette declaring the person who has received the greatest number of votes in the election ... to have been elected president' (Kenya 1998a, my emphasis).

The impact of the ECK's decision to declare Kibaki the winner of the presidential election before the all the votes had been counted cannot be over

3 For a review of these laws and amendments in relation to the legal regime in Kenya see Amnesty International 1997; Okondo 1995; Wachira 1996. 
emphasised, particularly with respect to the relevance and sanctity of the doctrine of the separation of powers. The National Assembly and Presidential Elections Act, for example, is premised on the principles of impartiality and independence and the members of the electoral commission are expected to perform their duties 'without fear, favour, or prejudice and without influence from the government, public officer, political party, candidate participating in an election, and any other person or authority' (Kenya 1998a, Second Schedule; Kenya 1998b, Second Schedule).

Four interrelated issues are critically important and have implications for the doctrine of separation of powers.

The first of these is that at the time the negotiations began Mwai Kibaki had already been sworn in as president, as prescribed in s8 of the Constitution, making him the only elected leader who had taken the oath of office. This gave the PNU, of which Kibaki is the leader, more leverage than the ODM. Those PNU and ODM members of Parliament who were part of the negotiating team participated in the negotiations, initially at least, as ordinary citizens because when the negotiations began they had not yet taken the oath of office, as prescribed by s49(1) of the Constitution.

Secondly, the legal framework of the GNU does not provide for the establishment of the office of the president. Specifically, the GNU was established after Kibaki, acting alone and potentially in contravention of the Constitution and the electoral laws, had already assumed his executive powers.

Thirdly, the legal framework is silent on the specific timeframe for its provisional operations before the 2012 general elections. However, s6(a-c) of the Act implies that the GNU is expected to operate until 2012, or as circumstances may dictate. The section states that 'the coalition shall stand dissolved if (a) the Tenth Parliament is dissolved (b) the coalition partners agree in writing (c) one coalition partner withdraws from the coalition by a resolution of the highest decision-making organ of that party in writing' (Kenya 2008b). Chapter II, s9(1) of the Constitution of Kenya, stipulates that ' $t \mathrm{t}$ ] he President shall hold office for a term of five years beginning from the date on which he is sworn in as President' (Kenya 2001). ${ }^{4}$ Fourth, in my view, the GNU lacks ownership by the people, whose sovereign rights were not strictly adhered to during the general elections. ${ }^{5}$ Laver \& Shepsle (1996, p 4) correctly observe: 'Elections have meaning for voters because they provide a choice between different packages of possible political outcomes, offered by different political parties.'

$4 \quad$ For details of the draft constitution see Kenya 2005.

5 On the importance of involving the people in constitution-making in Africa, see Mutunga 1999; Hoyden \& Venter 2001; Barkan 1998; Oloka-Onyango 1996. 
Kenya, like any other established or emerging democratic state, should conduct its elections within the framework of universal standards and institutions as well as in conformity with its own national laws and procedures. ${ }^{6}$ Although Kenya is a contracting party to international instruments which govern electoral process it has not ratified the 2002 Organisation of African Unity (now the African Union) Declaration on Principles Governing Democratic Elections in Africa and the 2007 African Charter on Democracy, Elections and Governance (Kriegler Report 2008, p 12). ${ }^{7}$

It is not far-fetched to categorise the National Accord and Reconciliation Act as an extra constitutional plebiscite by the pen, an exercise entered into by the political leaders to legitimise political cohabitation and demonstrate a modicum of political stability in a country plagued by post-election violence. The signing of the agreement contrary to the popular will of voters who participated in the elections is akin to a presidential decree (Carey \& Shugart 1998; Mainwaring \& Shugart 1997) or what others have called elective dictatorship (Hailsham 1976).

In my view the coalition government may potentially erode the bedrock of democratic ideals that Kenyans have enjoyed, albeit with problems, since the reintroduction of multipartyism in 1991. The doctrine of separation of powers remains an elusive concept in Kenya, with its structure and functions skewed and solidified in favour of the executive in the legal framework of the GNU.

The Act which established the GNU is worded in such a way that it carefully and deliberately excludes the words executive authority in relation to the office of the prime minister (PM). Section 4(1)(a) states: 'The Prime Minister shall have authority to co-ordinate and supervise the execution of the functions and affairs of the Government, including those of the Ministers' (Kenya 2008b, my emphasis).

The prime minister's post, as provided for in the Act, is largely non-executive, with limited powers in relation to the presidency. Part 3 of the Constitution vests the executive authority of the government in the president - authority that Mwai Kibaki assumed when he took the oath of allegiance prior to the commencement of the negotiations.

Section 4(2) of the Act limits the authority of the prime minister further, stating that: 'in the formation of the coalition Government, the persons to be

6 International institutions that govern universal standards of elections include, for example, the Universal Declaration of Human Rights (UDHR 1948), the International Covenant on Civil and Political Rights (ICCPR 1966), the International Covenant on the Elimination of All Forms of Racial Discrimination (ICERD 1963), the Convention on the Elimination of All Forms of Discrimination Against Women (CEDAW 1979), and the Convention on the Rights of Persons with Disabilities (CRPWD 2006).

7 The constitutional and legal framework that governs elections in Kenya includes: the Constitution, the National Assembly and Presidential Elections Act (Cap 7 of the Laws of Kenya), the Local Government Act (Cap 265), the Societies Act (Cap 108), the Public Order Act (Cap 56), the Penal Code (Cap 63), the Kenya Broadcasting Corporation Act (Cap 221), and the Registration of Persons Act (Cap 107). 
appointed as Ministers and Assistant Ministers from the political parties that are partners in the coalition other than the President's party shall be nominated by the parliamentary leader of the party in the coalition and thereafter there shall be full consultation with the President in the appointment of all Ministers' (Kenya 2008b, my emphasis).

The PM's input into the appointment of ministers who are members of the PNU (the president's party) remains at the consultative level, that is, after the president has made the nominations. The constitutional right to appoint the vicepresident, the PM, deputy prime ministers, ministers and assistant ministers is vested in the president (Kenya 2001; 2008b).

The National Accord and Reconciliation agreement driven by the executive powers, effectively disenfranchised and subordinated the popular will of the people of Kenya and it must be noted that history is repeating itself. In 1982 Mwai Kibaki, then vice-president and leader of government business in the National Assembly, rushed a Bill through Parliament in one day, transforming Kenya into a de jure one-party state, which, by implication, undermined the separation of powers. In 2008 under Kibaki's presidency the National Accord and Reconciliation Bill was rushed through the National Assembly and became law in March of that year, transforming Kenya into what, technically, remains a de facto one-party state, again, with adverse effects on the separation of powers (Kenya 2008b).

Among the principles detailed in the preamble to the Act are the following:

- Portfolio balance. Section 4(3) provides that 'the composition of the coalition government shall at all times reflect the relative parliamentary strength of the respective parties and shall at all times take into account the principle of portfolio balance'.

- Coalition and partnership. The principle parties to the accord, that is, the PNU, the ODM and the affiliated political parties, are to transact and promote the business of coalition in the spirit of partnership.

- Power-sharing to foster healing and national reconciliation. The central objective of the contracting parties to the agreement was to ensure equity to defuse further conflict under the prevailing uncertain situation.

- Willingness to compromise. The survival and functional operation of the coalition government is contingent upon the willingness of the parties to compromise on inter-party and national issues.

- Mutual trust and confidence. The issue of mutual trust and confidence 
is critical for the survival of the coalition government, particularly given the volatility of the post-election violence and the uncertainty surrounding the outcome of the presidential elections.

The Act establishes the offices of prime minister and two deputy prime ministers (PMs). This is the second time in Kenya's independence history that the office of the PM has been entrenched in the Constitution. The first time was the 1962 Lancaster House Constitution establishing the country's independence and which saw Jomo Kenyatta, the leader of Kanu, taking over the premiership in 1963.

The legal framework of the GNU has expanded the role of the executive to include the president, the PM, the vice-president, deputy PMs, and Cabinet ministers, all of whom exercise dual roles as members of the executive and as elected legislators, putting into question the relevance of the separation of powers.

The prime minister is both a member of Parliament and the leader of either the largest political party or a coalition of political parties in the National Assembly, a requirement which puts the PM in a delicate political situation. Firstly he or she must ensure that the party or the coalition under his or her leadership maintains its majority in the legislature. Secondly, any rebellion within the PM's party or coalition, which may lead to defections followed by by-elections and the potential loss of majority in the National Assembly, may jeopardise the PM's position.

Whereas s3(1) of the National Accord and Reconciliation Act provides that the PM and the deputy PMs shall be appointed by the president, the power to remove them through a motion of no confidence is vested in the National Assembly (Kenya 2008b). The Act also provides that 'the removal of any Minister of the coalition will be subject to consultation and concurrence in writing by the leaders' (Kenya $2008 \mathrm{~b}$, preamble). These clauses contradict certain sections of the Constitution, particularly that relating to the executive powers of the president.

While s16 (3)(a) of the Constitution stipulates that 'the office of a Minister shall become vacant if the President so directs', s25(1) provides that 'save in so far as may be otherwise provided by this constitution or by any other law, every person who holds office in the service of the Republic of Kenya shall hold that office during the pleasure of the President' (Kenya 2001).

At issue here is the doctrine of the separation of powers, particularly with respect to the relationship between the executive and the legislature. ${ }^{8}$ The

8 These sections were not included in the Amendment Bill which established the GNU. The sections of the Constitution which the Bill proposed to amend include ss 3 and 17. Section 3, for example, states in part: 'if any other law is inconsistent with this Constitution, this Constitution shall prevail and the other law shall, to the extent of the inconsistency, be void'. 
government may be paralysed if the executive and the legislature disagree on any issue relating to the dismissal of the PM, deputy PMs or a Cabinet minister. On the other hand, the president may decide to invoke his executive powers, jeopardising the GNU's raison d'être and its operational functions.

\section{THE DOCTRINE OF SEPARATION OF POWERS AND THE NATIONAL LEGISLATIVE ASSEMBLY IN THE GNU LEGAL FRAMEWORK}

The Constitution of Kenya (Amendment) Bill setting out the legal framework of the GNU and tabled in Parliament by the government in March 2008 received overwhelming support from the MPs in the Legislative Assembly, who were influenced by both the volatility and instability in the country and their personal political survival.

There was consensus on a number of issues considered pertinent to the restoration of confidence among Kenyans and to the attempt to move the country out of its post-election political quagmire. The issues included, among others, a full review and adoption of the new constitution or the Bomas draft, the organisation of an ethnicity conference to address inter-ethnic differences, willingness to compromise, mutual trust, partnership, settlement of the IDPs and the need to address the land question comprehensively (Kenya 2008c, cols 280-226). As stated above, the new structure and functions put in place by the Act were distinct in many respects from any that had existed in Kenya since independence.

This paper seeks to explore certain areas of fusion of powers in relation to the Legislative Assembly and its law-making role vis-à-vis that of the executive, particularly in light of the power-sharing model concluded in 2008 by the PNU and the ODM. Technically, under the GNU legal framework the National Assembly is operating without an official opposition, which puts in question the role of the legislature as the law-making institution. As the representative of the people and the custodian of democracy Parliament must remain the watchdog of the excesses of the executive. In other words, 'parliaments must be and must see themselves as both the custodians and promoters of democratic values and assume the responsibility for consolidating democracy' (Ginwala 2003, p 3).

In Kenya, for example, for accountability purposes, the Public Accounts Committee and the Public Investments Committee are chaired by a 'Member who does not belong to the parliamentary party which is the ruling party' (Kenya 2002, ss147(1) and 148(1)). Section 148(5) of the National Assembly Standing Orders enumerates the role of the Public Investments Committee, which is:

- to examine the reports and accounts of the public investments; 
- to examine the reports, if any, of the Auditor-General (Corporations) on the public investments;

- to examine, in the context of the autonomy and efficiency of the public investments, whether the affairs of the public investments are being managed in accordance with sound business principles and prudent commercial practices.

Kenya 2002.

The above indicates clearly the importance Parliament attaches to the role of the opposition in the Legislative Assembly.

As indicated above if the National Assembly (Parliamentary Opposition) Bill 2008 is enacted it will broaden the legal and institutional scope of the responsibilities of the official opposition by empowering the backbench caucus to play the traditional role of a properly constituted official opposition.

Section 12(1) provides that 'the Backbench Caucus shall not be a political party and membership thereof shall not in any way affect the membership of a member of parliament in his or her political party' (Kenya 2008a). It is important to note that the Bill aims to address the historical anomaly of the role of the official opposition and the GNU legal framework as well as any future political dispensation that may adversely affect the role of the official opposition. The underlying principle of s3(2) is that a party in government cannot, at the same time, play the role of official opposition. However, the leaders of the political parties, particularly the PNU and the ODM, are unwilling to accommodate internal divisions within their ranks in Parliament which may have an adverse impact on inter- and intra-party strategies. The other problem the group faces relates to s17(4) of the Political Parties Act, which provides that:

a person who, while a member of a political party (a) forms another political party (b) joins in the formation of another political party (c) joins another political party or (d) in any way or manner, publicly advocates for the formation of another political party... shall be deemed to have resigned from the previous political party

Kenya 2007 (my emphasis)

Even if the objective of the backbench caucus is merely to form an association within the precincts of Parliament to play the role of official opposition the Act would still render such good intensions nugatory. Section 18(1) of the Political Parties Act states that 'an association of persons or an organization shall not operate or function as a political party unless it has first been registered in accordance with the provisions of this Act' (Kenya 2007). 
The issue of the distribution of ministerial posts, which almost derailed the GNU negotiations, is worth a brief appraisal.

Figure 3, which compares the size of the Cabinets of presidents Kenyatta, Moi and Kibaki shows that under Kibaki the number of ministers appointed increased from 10 per cent of parliamentarians in 2003 to 14 per cent in 2004 and 16 per cent 2005.

Figure 3

Numbers of Cabinet ministers during the regimes of Kenyatta, Moi and Kibaki*

\begin{tabular}{|c|c|c|c|c|c|c|c|}
\hline $\begin{array}{l}\text { PRESIDENT } \\
\text { JOMO } \\
\text { KENYATTA } \\
(1964-1978)\end{array}$ & 1964 & 1966 & 1967 & 1968 & 1970 & 1978 & \\
\hline $\begin{array}{l}\text { Number of } \\
\text { ministers }\end{array}$ & 20 & 21 & 21 & 20 & 21 & 21 & \\
\hline $\begin{array}{l}\text { Total number of } \\
\text { elected MPs }\end{array}$ & 113 & 158 & 158 & 158 & 158 & 158 & \\
\hline $\begin{array}{l}\text { Ministers as } \\
\% \text { of seats in } \\
\text { Parliament }\end{array}$ & $18 \%$ & $13 \%$ & $13 \%$ & $13 \%$ & $13 \%$ & $13 \%$ & \\
\hline $\begin{array}{l}\text { PRESIDENT } \\
\text { DANIEL ARAP } \\
\text { MOI (1978-2001) }\end{array}$ & 1979 & 1982 & 1983 & 1987 & 1994 & 1998 & 2001 \\
\hline $\begin{array}{l}\text { Number of } \\
\text { ministers }\end{array}$ & 26 & 27 & 25 & 28 & 24 & 27 & 28 \\
\hline $\begin{array}{l}\text { Total number of } \\
\text { MPs }\end{array}$ & 158 & 158 & 158 & 188 & 188 & 210 & 210 \\
\hline $\begin{array}{l}\text { Ministers as } \\
\% \text { of seats in } \\
\text { Parliament }\end{array}$ & $16 \%$ & $17 \%$ & $16 \%$ & $15 \%$ & $13 \%$ & $13 \%$ & $13 \%$ \\
\hline $\begin{array}{l}\text { PRESIDENT } \\
\text { MWAI KIBAKI } \\
\text { (2002- }\end{array}$ & 2003 & 2004 & 2005 & 2008 & & & \\
\hline $\begin{array}{l}\text { Number of } \\
\text { ministers }\end{array}$ & 22 & 29 & 34 & 41 & & & \\
\hline
\end{tabular}




\begin{tabular}{|l|r|r|r|r|r|l|l|}
\hline $\begin{array}{l}\text { Total number of } \\
\text { elected MPs }\end{array}$ & 210 & 210 & 210 & 210 & & & \\
\hline $\begin{array}{l}\text { Ministers as } \\
\text { o of seats in } \\
\text { Parliament }\end{array}$ & $10 \%$ & $14 \%$ & $16 \%$ & $20 \%$ & & & \\
\hline
\end{tabular}

Sources: Institute for Education in Democracy 1997; Kanyinga 2007; Kibaki 2008.

*The number of members of Parliament does not include the 12 nominated by the president according to the provisions of $\mathrm{s} 33$ of the Constitution.

As some scholars have observed, the expansion of a Cabinet for the purposes of controlling Parliament and other governmental operational functions may have adverse effects on delivery and accountability (Laver \& Shepsle 1996). As Figure 3 indicates the 41 PNU and ODM ministers appointed by President Kibaki account for more than 20 per cent of the elected MPs, a figure that increases dramatically if assistant ministers are included.

Kenya's legislative assembly, like any other properly and constitutionally constituted legislature, derives its authority and legitimacy from the people, that is, through the electoral process. Jean-Jacques Rousseau (1712-1778), in his celebrated classical work the Social Contract (1762), postulated, among other things, that legislative powers are vested in the people, giving popular sovereignty its theoretical and practical credibility. ${ }^{9}$

Rousseau's theoretical postulation on popular sovereignty, which has evolved over the centuries, provides a clear nexus between the people (the electorate), the legislators, and the legislature. This triadic link is critical to an understanding of the sanctity of the doctrine of the separation of powers, specifically the law-making authority vested in the legislators' role.

The general practice in established or emerging democracies, Kenya included, is that the authority for the role of the legislators vests in the ballot box and takes legal and legislative effect once they are sworn in after an election.

Chapter III, Part 2, s49(1) of the Constitution provides, in part, that: 'every member of the National Assembly shall, before taking his seat in the Assembly, take and subscribe the oath of allegiance before the Assembly...'(Kenya 2001). It is this oath that legitimately and constitutionally formalises the powers of the legislators. Chapter III, Part I, para 30 of the Constitution provides that 'the legislative power of the Republic shall vest in the Parliament of Kenya, which shall consist of the President and the National Assembly' as well as elected,

9 For interpretations of the works of Rousseau, see Melzer 1990 and Held 2000. 
nominated and ex officio members (Kenya 2001). ${ }^{10}$ Unless otherwise prescribed by the Constitution only the legislators vote in the proceedings of the National Assembly. ${ }^{11}$ The overriding original intention of the newly-elected ODM and PNU legislators who participated in the GNU negotiations and who were yet to take the oath of allegiance was to amend the Constitution. The circumstances under which the negotiations took place remain questionable. In my view, the 2008 GNU framework has led to a regression of democracy and placed in question the separation of powers.

\section{RECOMMENDATIONS}

The GNU should, in my view, give careful attention to a number of issues.

- Its formation and legitimacy should be tested in a referendum.

- The GNU Cabinet remains a heavy burden on a country with meagre resources and should be reduced to an affordable size.

- The GNU should operate as an interim government for a maximum of two years and fresh presidential elections should be held before 2012. The failure of the Kriegler and Waki commissions to give a clear verdict on the winner of the 2007 presidential election makes this recommendation pertinent.

- The law-enforcement agencies, particularly the police, should be retrained to enable them to deal with civilians without using excessive force.

- The new Constitution should be adopted and implemented in toto prior to the 2012 general elections. ${ }^{12}$

\section{CONCLUSION}

The GNU should be considered a temporary modus vivendi because it has not been put to the test through a referendum and the leaders who are parties to the agreement have violated the sovereign rights of the electorate.

10 The Attorney General is an ex officio member of the National Assembly.

11 Section 56, para 2 of the Constitution provides that 'subject to this Constitution, the National Assembly may act notwithstanding a vacancy in its membership (including a vacancy not filled when the Assembly first meets after a general election), and the presence or participation of a person not entitled to be present at or to participate in the proceedings of the Assembly shall not invalidate these proceedings'.

12 For details of the views expressed by Kenyans and other stakeholders during the drafting of the new constitution see Constitution of Kenya Review Commission 2003. 
Although the Kriegler and Waki commissions provided useful information about the December 2007 electoral debacle it is doubtful whether the Kibaki administration will implement their recommendations in toto. Implementation of the recommendations would, by implication, mean putting on trial some key figures in government, and their accomplices. If the reluctance to implement the recommendations of similar commissions established in the past in Kenya is anything to go by, it is unlikely that the alleged perpetrators will be given an opportunity to prove their innocence in court.

The GNU has brought together former competitors across the political divide in a fragile alliance. It is in the interests of the PNU and the ODM that stability prevail within the GNU and the leaders of the two parties are watching nervously the persistent inter- and intra-party differences and instabilities, any of which may lead to one of the contracting parties disintegrating. Of critical importance, particularly for an emerging democracy like Kenya, is the issue of consolidation and institutionalisation of the separation of powers.

As I have shown in this paper, ever since Kenya became independent the executive has dominated the other branches of government. Two interrelated issues are worth reiterating, particularly with respect to adherence to the doctrine of the separation of powers. First, the draft constitution, which provides for a clear separation of powers, must be adopted and implemented. Secondly, Kenya needs a transformative leader, that is, an individual who is willing to consolidate and institutionalise democracy and is committed to fundamental change. As one MP observed in the Legislative Assembly during the debate on the GNU Bill, the civil strife that engulfed the country after the elections was the result of the leadership's resistance to change (Kenya 2008c, col 197).

\footnotetext{
This paper, which was presented at the South African Association of Political Science Biennial Conference, organised by the University of Johannesburg, 3-5 September 2008, and at a seminar organised by the Africa Institute of South Africa, Pretoria, 20 March 2009, is an abridged version of a monograph entitled The Doctrine of the Separation of Powers and the GNU Legal Framework: The 'Place' of Kenya's National Legislative Assembly. The study was conducted in Kenya, between May and June 2008, with financial support from the Africa Institute of South Africa. I am indebted to a number of people who provided useful information for the study. Due to lack of space only a few will be mentioned here: Hon Dr Kilemi Mwiria, Assistant Minister, Higher Education, Kenya; Judson Oriema Okoth of Okoth and Kiplagat Advocates, Kenya; Maina Kiai, Kenya National Commission of Human Rights, Kenya; Thomas Joseph Mboya and Patricia Ochieng, Maseno University, Kenya; Shitsimi P Anjimbi, National Statistical System Project, Ministry of Planning and National Development, Kenya; Fredrick Otoro, Tumsifu Centre, Kisumu, Kenya; Dalmas Oleko, Bible Society of Kenya, Kisumu, Kenya, Joshua Osewe, Diocese of Maseno, Kisumu, Kenya; Kepta Ombati, Youth Agenda Secretariat, Kenya, the International Organization for Migration, Nairobi, Kenya; and Ayub Imbira, Electoral Commission of Kenya, Nairobi, Kenya. It should be noted that some officials from the government and the NGOs in Kenya provided useful information but requested to remain anonymous. I am grateful for the comments made by participants in both the conference and the seminar as well as suggestions from the following colleagues who read the earlier drafts of this manuscript: Patrick Loch Otieno Lumumba, Faculty of Law, University of Nairobi, Kenya; Rok Ajulu, University of South Africa, Pretoria; and Monica Juma, Norman Mlambo, and Biong Deng, AISA, Pretoria. I, however, remain solely responsible for the paper's shortcomings.
} 


\section{- REFERENCES}

Adar, K G. 1994. Kenyan Foreign Policy Behavior Towards Somalia, 1963-1983. Lanham: University Press of America.

1998. 'Ethnicity and Ethnic Kings: The Enduring Dual Constraint in Kenya's Multiethnic Democratic Electoral Experiment'. Journal of the Third World Spectrum 52, Fall.

1999. 'Human Rights and Academic Freedom in Kenya's Public Universities: The Case of the Universities Academic Staff Union'. Human Rights Quarterly 21(1), February.

2000. 'Assessing Democratisation Trends in Kenya: A Post-mortem of the Moi Regime'. Commonwealth \& Comparative Politics 38(3), November.

__. 2008. 'Leadership Crisis and the Debacle of Kenya's $27^{\text {th }}$ December 2007 General Elections. AISA Policy Brief 1, April.

Ackerman, B. 2000. 'The New Separation of Powers'. Harvard Law Review 1133.

Amnesty International. 1997. Violation of Human Rights - Communication Between Amnesty International and the Government of Kenya. London: Amnesty International, AI Report 32/2.97.

Barber, N W. 2001. 'Prelude to the Separation of Powers'. Cambridge Law Journal 60. Barendt, E. 1995. 'Separation of Powers and Constitutional Government'. Public Law. Barkan, J D. 1998. 'Toward a New Constitutional Framework in Kenya'. Africa Today 452, April-June.

Carey, J M \& M S Shugart (eds). 1998. Executive Decree Authority. New York: Cambridge University Press.

Commission of Inquiry into Post-Election Violence. 2008. Nairobi: CIPEV.

Constitution of Kenya Review Commission. 2003. Report of the Constitution of Kenya Review Commission, Vols 1-5, Technical Appendices, Parts 1-5. Nairobi: Constitution of Kenya Review Commission.

Electoral Commission of Kenya. 2006. Kenya Constitutional Referendum, 2005.

Nairobi: Electoral Commission of Kenya.

— 2008. 27 $7^{\text {th }}$ December 2007 General Election Results: Elected Members of Parliament per Political Party. Nairobi: Electoral Commission of Kenya.

Ely, J H. 1980. Democracy and Distrust: A Theory of Judicial Review. Cambridge, MA: Harvard University Press.

Ginwala, F. 2003. The Role of Parliament in Meeting the Challenges of Globalization to Democratic Governance in Africa. DPMF Occasional Paper No 8. Addis Ababa: Development Policy Management Forum.

Hailsham, Lord. 1976. Elective Dictatorship: The Richard Dimbleby Lecture. London: British Broadcasting Service.

Held, D. 2000. Sovereign Virtue. Cambridge, MA: Harvard University Press. 
Hoyden, G \& D Venter (eds). 2001. Constitution-making and Democratization in Africa. Pretoria: Africa Institute of South Africa.

Independent Review Commission. 2008. Report of the Independent Review Commission on the General Elections Held in Kenya on $27^{\text {th }}$ December 2007. Nairobi: IREC.

International Bar Association. 1996. Report on the Legal System and Independence of the Judiciary in Kenya. New York: International Bar Association.

International Commission of Jurists. 1998. The State of the Rule of Law in Kenya, 1997 Report. Nairobi: ICJ-Kenya Section.

Institute for Education in Democracy. 1997. National Elections Data Book: Kenya, 19631997. Nairobi: Institute for Education in Democracy.

Jennings, I. 1959. Law and the Constitution $5^{\text {th }}$ ed. London: University of London Press. Kanyinga, K. 2007. Ethnic Inequalities in Kenya. Institute for Development Studies, University of Nairobi, mimeo.

Kenya. 1963. National Assembly, Senate, Official Report vol 2, December. 1983. The Constitution of Kenya, rev ed. Nairobi: Government Printer. 1997a. The Constitution of Kenya Amendment Act, 1997. Kenya Gazette Supplement 70 Acts No 7, 7 November. Nairobi: Government Printer.

1997b. The Statute Law Repeals and Miscellaneous Amendments Act, 1997. Kenya Gazette Supplement 70 Acts No 7, 7 November. Nairobi: Government Printer. 1998a. The Constitution of Kenya Review Commission Amendment Act, 1998. Kenya Gazette Supplement 72 Acts No 6. Nairobi: Government Printer. 1998b. Laws of Kenya, The National Assembly and Presidential Elections Act rev ed. Nairobi: Government Printer.

1999. Report of the Judicial Commission Appointed to Inquire into Tribal Clashes in Kenya, the Commission of Inquiry Act Cap 102, 31 July. Nairobi: Government Printer.

2001. The Constitution of Kenya, rev ed. Nairobi: Government Printer.

2002. National Assembly Standing Orders, rev ed. Nairobi: Government Printer. 2004a. Report of the Commission of Inquiry into the Illegal/Irregular Allocation of Public Land, June. Nairobi: Government Printer. 2004b. Report of the Commission of Inquiry into the Illegal/Irregular Allocation of Public Land, Annexes Vol I, June. Nairobi: Government Printer. 2004c. Report of the Commission of Inquiry into the Illegal/Irregular Allocation of Public Land, Annexes Vol II, June. Nairobi: Government Printer.

2005. The New Constitution of Kenya. Special Issue, Kenya Gazette Supplement 63, 22 August. Nairobi: Government Printer.

2007. Political Parties Act. Kenya Gazette Supplement 106, Acts No 10. Nairobi: Government Printer.

2008a. The National Assembly Parliamentary Opposition Bill, 2008. Kenya Gazette Supplement 60, Bills No. 19 Nairobi: Government Printer. 
2008b. The National Accord and Reconciliation Act. Kenya Gazette Supplement 20, Acts No 4, 20 March. Nairobi: Government Printer.

2008c. National Assembly, Parliamentary Debates. Official Records, Hansard.

Nairobi: National Assembly.

2008d. The Constitution of Kenya Amendment Bill, 2008. Revised Working Document. Nairobi: Government Printer.

Kenya Human Rights Commission. 1998. Killing the Vote: State Sponsored Violence and Flawed Elections in Kenya. Nairobi: KHRC.

Kibaki, M. 2008. 'Speech by His Excellency Hon. Mwai Kibaki, C.G.H., M.P., President and Commander-in-Chief of the Armed Forces of the Republic of Kenya During the Announcement of the Grand Coalition Government'. http://africanpress.wordpress. com/2008/04/13/here-is-the-kenya-government-kibaki-s

Kriegler, J. 2008. Independent Review Commission Report.

Kuria, G K. 1995. 'Freedom of Expression and the Contempt of Court'. Paper Presented at the Second International Commission of Jurists Kenya Section Workshop on Administration of Justice in Kenya Courts as Guardians of Justice, 30 March.

Kyle, K. 1999. The Politics of Independence of Kenya. London: Macmillan.

Labuschagne, P. 2004. 'The Doctrine of Separation of Powers and its Application in South Africa'. Politeia 23(3).

La France, G. 1989. Studies on the Social Contract. Ottawa: Ottawa University Press.

Laver, M \& K A Shepsle. 1996. Making and Breaking Governments: Cabinets and Legislatures in Parliamentary Democracies. New York: Cambridge University Press.

Mainwaring, S \& M Shugart (eds). 1997. Presidentialism and Democracy in Latin America. New York: Cambridge University Press.

Melzer, A. 1990. The Natural Goodness of Man: On the System of Rousseau's Thought. Chicago: Chicago University Press.

Mutunga, W. 1999. Constitution-Making From the Middle: Civil Society and Transition Politics in Kenya, 1992-1997. Nairobi: SAREAT.

National Council of Churches. 1992a. Report of the Task Force. Nairobi: CCK. 1992b. The Cursed Arrow: Organized Violence Against Democracy in Kenya. Nairobi: NCCK.

Nowrojee, E. 1992. 'Kenya: Political Pluralism, Government Resistance, and United States Responses'. Harvard Human Rights Journal 5.

Ojwang, J B. 1976. 'Executive Power in Independent Kenya's Constitutional Context'. Nairobi: University of Nairobi, LLM dissertation.

Okondo, P H. 1995. A Commentary on the Constitution of Kenya. Nairobi: Phoenix Publishers.

Oloka-Onyango, J. 1996. In Search of Freedom and Prosperity: Constitutional Reform in East Africa. Nairobi: Claripress. 
Rautenbach, I M \& E F J Malherbe. 1996. Constitutional Law. Durban: Butterworth's.

Robert F. Kennedy Memorial Center for Human Rights. 1992. Justice Enjoined: The State of the Judiciary in Kenya. New York: Robert F. Kennedy Memorial Center for Human Rights.

Rousseau, J J. 1954 ed. The Social Contract, translated by Willmore Kendall. Chicago: Henry Regency Company.

Solomon, J A. 1994. Failing the Democratic Challenge: Freedom of Expression in MultiParty Kenya - 1993. Washington, DC: The Robert F. Kennedy Memorial Center for Human Rights.

Throup, D W \& C Hornsby. 1998. Multi-Party Politics in Kenya: The Kenyatta and Moi States and the Triumph of the System in the 1992 Elections. Oxford: James Currey.

Vile, M J C. 1998. Constitutionalism and the Separation of Powers, $2^{\text {nd }}$ ed. Indianapolis: Liberty Fund.

Wade, E C S \& G G Phillips. 1979. Constitutional and Administrative Law. London: Longman.

Wachira, W. 1996. 'Constitutional Crisis in Kenya: An Inquiry into its Origins, Nature, and Prospects for Reform'. Paper Presented at IPAR Project on Constitution-Making in Kenya, November/December.

Waki, P. 2008. Report of the Independent Review Commission, http: / / wikileaks.org/ wiki/kenya:_waki_commission_of_Inquiry_into_Post-Election_Violence_ final_report_15_Oct_2008 


\title{
ETHNICITY AND POLITICAL PLURALISM IN KENYA*
}

\author{
Shilaho Westen Kwatemba
}

\author{
Shilaho Kwatemba is a PhD Candidate in the Political Studies Department, \\ University of the Witwatersrand, Johannesburg \\ e-mail:wshilaho@yahoo.com
}

\begin{abstract}
This paper focuses on the salience of ethnicity in Kenya since the return to political pluralism in 1991. It argues that ethnicity as a variable in Kenya's political processes dates back to the colonial period. Successive governments in that country, beginning with the Jomo Kenyatta state in 1963, perfected the aspect of ethnicity that dovetailed with patronage, rent-seeking and prebendalism to the detriment of the nation state. The paper engages with the theoretical underpinnings of ethnicity in an attempt to understand its overwhelming influence on Kenya's politics, especially in the multiparty era. The thrust of the argument is that unless there is the political will to re-engineer Kenya's polity both politically and constitutionally the nationbuilding project will remain convoluted, frustrating and stillborn.
\end{abstract}

\section{INTRODUCTION}

Kenya is among the few African countries that, for a considerable period after independence, maintained a reputation for uninterrupted peace. This was a remarkable achievement given that the country has had its fair share of turbulent times. The Kenyatta state (1963-78) muzzled nascent plural democracy a few years into independence. Subsequently intermittent political assassinations characterised the single-party era. A system of violence as an alternative to the free trade in ideas eventually mutated into a phase of ethnic clashes following Kenya's return to multiparty democracy in the early 1990s.

* This paper was presented during a workshop on Kenya with the theme Conflict Resolution in Kenya: Taking Stock of a Political Crisis at the University of the Witwatersrand, Johannesburg, on 18 July 2008. 
All these events served to put the country on a perilous political trajectory. With the banning of multypartyism robust debate was muzzled, political intolerance set in and opposition became subterranean. Rather than address the canker gnawing away at the country's body politic successive political leaders indulged in a dance of self-deception which exacerbated challenges such as the endemic but mundane corruption that faced the country and, alarmingly, bought into the self-constructed myth of a peaceful country.

The violence that erupted in the wake of the controversial 2007 presidential election tested Kenya's political stability more than ever before, almost plunging the country into full-blown civil strife. Like a festering wound it exposed the structural rot embedded in the country's system.

A confluence of irregularities pertaining to land allocation, an overbearing presidency, a pervasive culture of impunity, and ethnicisation of power, malfeasance and sheer mendacity among both the political elite and the rabble almost pushed Kenya over the precipice (GoK 2008, pp 22-36).

The crisis, however, also presented Kenyans with an invaluable opportunity to renew the country through institutional and constitutional reforms and it would be regrettable if the political elite squandered that opportunity and once more began playing politics with the grave issues facing the country. This paper, therefore, attempts to situate the interface between ethnicity and pluralism within the ambit of Kenya's historiography. The question is: why was ethnicity so overtly politicised in a politically pluralist Kenya?

The paper traverses Kenya's political landscape from the colonial period to the present, indicating that ethnic politics in the country has evolved over the years with the aid of politicians. The first section attempts to locate the origins of ethnicity in colonialism. The second and third sections form the theoretical framework within which ethnic politics in Kenya is analysed and interpreted. The third section specifically shows that corruption in Kenya's polity is inextricably intertwined with complex and complicated political relationships that provide the scaffolding for the maintenance of power.

In the fourth and fifth sections the paper attempts to analyse the salience of ethnicity in Kenya under both one-party rule and political pluralism. It concludes that whereas ethnicity manifested itself in both phases, in the one-party system the contest was often confined to intra-ethnic friction and rivalries among clans, sub-tribes and regionalism. In the multiparty system ethnic communities tended to collapse their internal differences into political contestations over state control. The paper, however, recognises that ethnicity did not neatly project itself in clearly defined colours in the two phases. There were nuances in the sense that ethnic solidarity perennially proved elusive in certain ethnic communities, such as the Luhya. 
The sixth section dwells on political alliances in the run-up to the 2002 general elections and their aftermath and tries to argue that whereas the Kenya African National Union (Kanu) lost the power it had maintained since independence in 1963, structural and institutional challenges inherent in Kenya's politics made it difficult for the country to institute the political, institutional, and constitutional reforms for which Kenyans yearn.

The seventh section grapples with the hotly contested and disputed 2007 presidential election, which nearly plunged the country into civil war. The most important lesson from the 2007 election is that though it is more than four decades since Kenya achieved independence separatist and sectarian inclinations among both politicians and their followers threaten the national civic ethos.

In conclusion the paper recaps some of the salient issues at the core of Kenya's postcolonial crisis and suggests ways in which the country might break out of the apparently immovable political gridlock that faces it.

\section{HISTORICAL BACKGROUND}

One of the most enduring attributes of the legacy of colonialism in post-colonial Kenya was a sense of ethnic division that found expression not only in terms of group identity, but also became a mobilising agent in pursuit of economic interests. This complex process of class formation intersected with attempts by the colonial regime to manage the attributes of a traditional society and its mobilisation to develop a colonial capitalist market. Therefore it is not easy to understand the ethnic incubus in Kenya's politics unless one goes back to colonial capitalism and its uneven impact on various ethnic groups (Kitching 1980, Leys 1975, Swainson 1977).

The origins of ethnic consciousness as manifested in Kenya's political processes lay partially in the arbitrary way in which the British colonialists based administrative boundaries and local government on cultural and linguistic lines, a decision informed by an assumption that Africans lived in tribes, so tribes must constitute the basis of colonial administration (Sandbrook 1985, pp 49-50).

Kenya, like most colonies in Africa, was the invention of colonialists, an invention which seemed to have been flawed from the start and hence was a crisis in the making because the invented territory brought together different ethnic communities, some of which had little or nothing in common culturally. Other communities were mutually hostile. This does not mean that cultural homogeneity is a sine quo non for political stability. What can be said is that culturally diverse ethnic communities will clash unless those in authority make a deliberate effort to engender coexistence among them.

Kenya has more than 42 disparate ethnic groups. These groups per se do 
not pose a threat either to the stability of the nation state or to themselves, since people do not fight one another simply because they have different cultural and linguistic attributes. Recurrent animosity among ethnic communities in Kenya was the result of the politicisation of ethnicity. Postcolonial leaders seem to have approached ethnicity with the same intent as the colonialists, failing to infuse a national civic culture within the country's body politic because those at the centre of power pursued insular, sectarian and self-serving interests.

On the threshold of independence it was a sense of nationalism, not ethnic considerations, that guided some of the decisions made by nationalist politicians. In 1961, for instance, Oginga Odinga and his fellow nationalists refused to enter independence negotiations with the British colonialists until Jomo Kenyatta was released from detention (Sunday Standard 4 2007). The reasoning was that to enter negotiations while Kenyatta and others were still in detention would be tantamount to betraying the collective cause that was supposed to bind all freedom fighters irrespective of their ethnic origin.

However, after independence in 1963 the leading political parties, the Kenya African National Union (Kanu) and the Kenya African Democratic Union (Kadu), became amalgams of ethnic groups. Kenyatta used an ethnic cabal to consolidate power in the office of the president and marginalised his erstwhile liberation colleagues such as Odinga (Throup \& Hornsby 1998, pp 12-20). To stave off opposition both the Kenyatta and Moi states conveniently imposed a one-party government on the pretext that it was necessary for the promotion of national unity and nation-building (Mutua 2008, p 40).

Kenyatta, in cahoots with a clique of politicians with ethnic inclinations, interfered with the doctrine of separation of powers by emasculating the judiciary and legislature and creating an imperial presidency soon after Kenya's independence. Most of the politicians who wielded political and economic power during Kenyatta's regime hailed from the Kikuyu community to which he belonged. This coterie regularly changed the Constitution in pursuit of unbridled power. The net effect was the creation of a presidential behemoth that resulted in a one-party dictatorship. Between 1963 and 1978 the Constitution was amended numerous times with the express object of consolidating power in the presidency (Ogot \& Ochieng' 1995, p 106). The amendments made nonsense of the whole idea of independence since they were a throwback to the authoritarian patterns of colonial rule (Haugerud 1995, p 51).

In addition to showing a lack of regard for the Constitution Kenyatta smothered a nascent multiparty democracy and established one-party rule, which created a veneer of well-managed ethnic relations beneath which lay repressive strategies such as detention without trial for dissenters (Osaghae 1994, p 6). This potentially cataclysmic approach to ethnic differences serves to mask ethnicity 
but it can neither lead to the elimination of ethnic cleavages nor can it extinguish them through repression or assimilation. To ensure peaceful coexistence among different ethnic groups ethnic cleavages must be managed (Osaghae 1994, p 6).

At the height of the post-election violence in January 2008 the post of prime minister was reinstated through a power-sharing agreement between the protagonists. The intensity of the violence-hitherto unknown in Kenya-showed how horribly bad Kenya's power contestations can go. If the post had not been cavalierly eliminated from the independence Constitution the violence might never have broken out.

Under Kenyatta the exercise of political power was so informal that the line dividing the then ruling party, Kanu, and an ethnic grouping called the Gikuyu, Embu, Meru Association (Gema) was invisible and Gema and Kanu office bearers were one and the same (Himbara 1994, pp 27, 94-95). In fact, under Kenyatta, Kanu was almost moribund as a functioning political party, making it easy for the Gema association to supplant it as the de facto ruling party (Throup \& Hornsby 1998, p 37) and to dominate Kenya's business and political landscape with abandon.

The shift from Kenyatta to Daniel arap Moi in 1978 saw Kanu assume a prominent place in Kenya's politics. Political careers began and ended with Kanu. Moi centralised power in his person and the party became the centre of political conflict. Even ordinary Kenyans could only ignore Kanu at the pain of personal grief. A Kanu membership card became almost essential for advancement in the civil service or access to loans and other state services (Throup \& Hornsby 1998, p 37).

In the course of my research I talked to a Kenyan who remembered having been asked to produce his Kanu identity card in 1985 by the notorious Kanu youth wingers before being allowed into a market in a rural market centre. ${ }^{1}$ Another Kenyan I spoke to remembered that in the 1980s it was mandatory for adults in Kenya to carry their Kanu identity cards most of the time. ${ }^{2}$ The Kanu youth wing was composed of both young and not-so-young people, particularly males, with the task of implementing party resolutions at grass-roots level. Single-party rule was at its zenith in the 1980s and any adult who failed to prove his or her Kanu membership might be accused of being a dissident.

Moi, who had served as vice-president for 11 years, ascended to the presidency after Kenyatta's death. He made no pretence of bringing in the sociopolitical and economic reforms for which Kenya was crying out after the bruises inflicted by his predecessor in the form of state repression, political assassination and the marginalisation of certain communities, particularly the Luo (Mutua 2008).

1 Interview with Professor C J Odhiambo, Johannesburg, 18 October 2008.

2 Interview with Dulo Nyaoro, Johannesburg, 30 October 2008. 
Moi stated from the outset that he would follow Kenyatta's style - his slogan was 'footsteps'. However, with time, the 'footsteps' ideology changed from Moi following in the footsteps of Kenyatta to that of everyone else following in those of Moi (Throup \& Hornsby 1998, p 38).

Moi's ideology, called 'nyayoism', comprised a plethora of elements such as Christian morality, developmentalism, nationalism, anti-tribalism, and even African socialism. It was more of a concoction of the triple elements of 'peace, love and unity', through which Moi attempted to stamp his political idiosyncrasies on Kenya's political arena, than a well thought out and enunciated political philosophy. Contrary to its portrayal as an avenue for galvanising people for development projects, 'nyayo' or 'nyayoism' was a nebulous ideology, which, reduced to its lowest common denominator, equated opposition against Moi's rule with 'anti-nyayoism'.

Failure to subscribe to it was construed as dissent against the Moi government (Katz 1985, p 158). Moi did not spell out clearly the relationship between his 'ideology' and the ideals and ethos he wished to impose upon Kenyans as firstgeneration African leaders such as Julius Nyerere did with Ujamaa (African socialism) or Kenneth Kaunda with humanism. While scholars grappled with the essence of 'nyayoism' Moi used it to forge for himself the image of a forgiving patriarch and statesman by pardoning political detainees and ordering them released from detention (Khapoya 1988).

Perhaps because he had worked under Kenyatta for so long Moi was not capable of leading the reform of the many socio-economic and political challenges that weighed down the country. During his time as Kenyatta's vice-president he had given total loyalty, so, once in office, he expected members of his government to mimic his sycophancy (Friedman-Sabar 1997, p 27). Most of his contemporaries perceived him as a political lightweight (Morton 1998, pp 128-30; Russell 1999, pp $69,71)$. Compared to the power brokers in Kenyatta's inner circle such as Charles Njonjo (Attorney General), Njoroge Mungai (Minister of Foreign Affairs) and Mbiyu Koinange (Minister of State), who were better educated and had the Kikuyu 'pedigree', Moi was seen as an intellectual Lilliputian and a political neophyte. As such the Kenyatta coterie concluded that it had no reason to fear his political game plan. Its members could not have conceived that Moi had a realistic chance of succeeding the geriatric Kenyatta (Morton 1995, pp 128-30; Russell 1999, pp 69, 71). However, once in office he decided to make up for his lack of charisma by resorting to direct populist appeals in a bid to create a power base distinct from that of Kenyatta (Throup \& Hornsby 1998, p 27).

It was the lingering knowledge that most of his contemporaries in the Kikuyu community had a dim view of him that partly accounted for Moi's paranoid rule from 1978 to 2002. His mien as a master of political poker began in 1982 as a result 
of an abortive coup staged by junior Air Force officers. However, his clampdown on dissidents preceded the attempted coup (Atieno Odhiambo 2002, p 227; Badejo 2006, pp 102-106). His rule was informed by a sense of political insecurity almost bordering on paranoia. This was manifested in the number of times he reshuffled his Cabinet, not as much because Cabinet members were inefficient but as a way of scuppering the development of alternative centres of influence (Kanyinga 1998). He came across as a mistrustful, calculating, scheming, sly politician who had no qualms about reneging on his promises (Daily Nation 24 December 2002). The corollary was that the politics of musical chairs became Kenya's characteristic, at the expense of economic and political stability. Moi's raison d'être seemed to be to keep his political feelers in the air for any whiff of dissent or disloyalty.

\section{THEORIES OF ETHNICITY}

The link between ethnicity and African politics was the subject of academic discourse long before many African countries embraced multiparty politics. In this section we will engage with some of the theories in the field of ethnicity as a theoretical backdrop against which to interpret Kenya's transition from singleparty rule to political pluralism; insights which may enhance understanding of why Kenya was prone to political instability after multiparty elections.

Brown (2000, p 6) defines an ethnic group as that community which claims common ancestry and sees the proof of this in the fact that its members display distinctive attributes relating to language, religion, physiognomy or homeland origin. Young argued that ethnicity is a concept that has no significance in isolation. His thesis is that any analytical attempt should begin from the premise that ethnicity is a relational concept. According to Young \& Turner (1985, p 139) 'we' can only find relevance in 'they'. In most cases those who define themselves as 'we' ascribe to themselves positive attributes and give negative and disparaging ones to the 'they' group. Lonsdale (2004, p 76) referred to this process as 'ourselves-ing' and 'othering' contained in moral ethnicity and political tribalism respectively. Brown (2000, p 6) states that members of an ethnic group believe there is a natural and emotional link between an individual and a community which makes ethnic consciousness the central component of individual identity.

Kasfir (1976, p 77) argues that some of the attributes of ethnicity, such as language, territory, and cultural practices, are objective and their objectivity is partially underscored by the fact that they are seen by both insiders and outsiders of a given ethnic community as significant indicators of identity to such an extent that they may be used as bases for political mobilisation.

However, according to Young (1976, p 48), ethnic communities change constantly and the defining attributes of ethnicity are not fixed. In one political 
situation these attributes may include language, territory, political unit, cultural values or symbols, in another some of them may be absent, so the extent to which they are defining characteristics varies according to circumstances. In consonance with Young's argument Bates (1983, p 165) holds that ethnic groups lack an 'objective basis' and are dynamic and sometimes 'invented'. Correspondingly, Chazan, Leiw, Mortimer, Rothchild \& Stedman (1999, p 108) argue that ethnicity is an issue of subjective perception with regard to common origins, historical memories, ties and aspirations.

In the 1950s and 1960s ethnicity in Africa and other countries defined as less developed was analysed through the primordial ${ }^{3}$ approach. It was believed at the time that ethnic conflict could only be understood through this approach (Brown 2000, p 9; Stone 1983, p 85). The reasoning was that political behaviour in such 'backward' societies was likely to be driven by emotion and instinct and based on ancestrally based 'tribal' affiliations. There was a misconception that the processes of modernisation would lead to more rational forms of political behaviour as development occurred, promoting either a universalistic rationality or an intrinsically democratic form of civic nationalism focused upon identification with the modern state rather than on the community of common ancestry (Brown 2000, p 9).

These approaches connoted atavism, so ethnicity was seen as a problem facing societies that were yet to fit into modernity. The existence of ethnic tensions in those societies was interpreted as a sign of backwardness and lack of 'civilised' ways of behaving. Thus ethnic tendencies were described as 'outbursts of inward and backward looking irrational intolerance' (Brown 2000, p 9). However, an attempt to portray ethnicity as being peculiarly an African and, by extension, Third World problem was contested. Stone $(1983, \mathrm{p}$ 85) cites a number of countries that emerged in the 20th century in Europe - Bulgaria and Yugoslavia to name but two - to dismantle the notion that ethnic nationalism was a primordial vestige of an era gone by and was confined to Africa.

At the threshold of independence some analysts imagined that primordial tendencies were the preserve of the masses in the rural areas and that the elite were immune to ethnic stereotypes because of their formal education (Hyden 1983, p 72). Beneficiaries of Western education were considered detribalised and disabused of the primordial thinking from which the rural masses needed to be weaned (Stone 1983, p 85). Political ethnicity is an enmeshing phenomenon and this negates the claim that the ethnic sensibilities of the elite differ substantially from those of the masses.

3 The primordial bond is the belief that one is born into a particular linguistic, racial or homeland community and therefore inevitably feels an overwhelming emotional bond with that community (Brown 2000 p 6). 
In Mamdani's reading it is the manner in which colonialists incorporated Africans into the modern state that set in motion the deft manipulation of ethnicity by the elite in postcolonial Africa. The elite ascribed to themselves the rights of citizenship while the masses remained 'tribal' beings (1996). Ironically, political mobilisation and modernisation, which Hyden mentions as issues that attenuate ethnic consciousness in Africa, are the very ones that enhance a sense of ethnic tension among communities on the continent. In consonance with Hyden's thesis Horowitz further argues that, contrary to the views of earlier analysts, ethnicity in Africa is not disappearing in proportion to advancement in modernisation. In his words: 'it has proven not to be an anachronism and the elites earlier considered to be leading people away from ethnic affiliations were the ones found to be in the forefront of ethnic conflict' (Horowitz 1985, p 97; Bates 1983, p 165).

Horowitz argues that social mobilisation enhances ethnic competition, particularly in a competitive modern sphere. Horowitz's thesis is that it is the competitor in the modern sector rather than the resident in rural Africa who feels the anxieties and insecurities of change and it is therefore this individual who is most likely to exploit tribalism for self-serving ends (Horowitz 1985, p 100; Bienen 1983, p 103). The question of whether ethnicity masks class interests is subject to debate. However, what cannot easily be disputed is that elites interpret integration and communal difference with other members of their communities and, in doing so, attempt to bridge the gap between themselves and the non-elites (Bienen 1983, p 103).

Brown (2000, pp 6-7), who analyses ethnicity and nationalism along the same lines, is of the view that the two concepts are intertwined. Ethnicity mutates into nationalism once it is actively and self-consciously mobilised in order to legitimate claims that an ethnic community has some rights of self-determination. To Brown a primordial approach depicts the nation as based upon a natural, organic community, which defines the identity of its members, who feel an innate and emotionally powerful attachment to it. Primordialism held that humanity has evolved into distinct, organic communities, each with its own language and culture, with each individual's identity derived from his or her location within one such community (Brown 2000).

Primordialism thus explains the occurrence of conflict and violence in modern nationalist politics as being caused by a disconnect between modern states and the boundaries of natural national communities which deserve and seek political autonomy (Brown 2000, p 6).

Instrumentalism is another theory used to interpret challenges stemming from ethnicity in Africa. While primordialism foregrounded culture as the basis of ethnic identities in Africa, according to the instrumental framework African politics is best analysed through the traditional-versus-modernity dichotomy. 
This theory holds that ethnicity becomes a defining criterion when groups are competing for scarce resources and values (Young \& Turner, 1985, pp 139-40).

In Africa access to power is important to various ethnic groups within a nation state because of the extensive intervention of the African state in many spheres of people's lives (Kanyinga 2001, p 354-5). Therefore the awesome power of the African 'leviathan' (Mutua 2008, p 40; Lonsdale 2008) forces individuals and ethnic groups to seek control of the state, or at least have some access to it as matter of security (Nnoli 1995, p 6).

Instrumentalism does not conceptualise ethnicity as an entirely bad thing. Thus ethnicity can take the instrumentalist angle either when members of a community want to extract advantages from the nation state or in an attempt to wriggle out of deprivation which they believe is politically induced (Young 1985, pp 139-40). Ethnic nationalism is analogous to a Janus face in the sense that despite its disruptive side ethnic-based movements have served as counter forces to the centralising and hegemonic ambitions of the modern territorial secular nationstate (Kagwanja 2003). Furthermore, ethnicity accords an individual a sense of belonging, especially in an impersonal, solitary and alienating urban setting prone to insecurity and destructive competition as a result of commodity markets (Nnoli 1995, p 4). In other words, ethnic identities have provided social safety nets which have cushioned many Africans from poverty, disease and illiteracy in the face of the debilitating effects of structural adjustment programmes (SAPs) and other policy excesses of globalisation (Kagwanja 2003).

Nnoli (1995, pp 4-5) argues that ethnicity is pivotal to the democratisation of a given nation state since it acts as a mobilising agent against issues of domination, oppression and exploitation by an unresponsive government. In this regard ethnicity is consistent with democratic ideals in which there is a quest for social justice, equity in distribution of resources, and accountability. The positive attributes of ethnicity are often subsumed by its negatives ones, since the latter are more dramatic, even catastrophic (Nnoli 1995, p 8). The major inadequacy of the instrumentalist approach is that it panders to colonial and anthropological stereotypes of Africa as a continent comprising stagnant and unchanging tribal societies (Berman 1998).

Instrumentalism conceptualises African politics as characterised by the manipulation of ethnic identities and loyalties for political and economic ends. Cynics disillusioned by the prevalence of the mercenary character and graft in post-independence African politics are among those who subscribe to this theory (Berman 1998).

The primordial and instrumentalist approaches appear to view the issue of ethnicity from two diametrically opposed standpoints. Whereas the latter factors into its interpretation terms such as 'contingent', 'situational', and 'circumstantial', 
as used in ethnic-based politics in pursuit of material advantage, the primordial model insists on the non-instrumental, deeply affective and emotional character of ethnicity. These attributes set instrumentalism apart from other bases of political identity and mobilisation (Berman 1998; Young 1985, pp 139-40).

Both primordial and instrumental theories are faulted for their inability to ground the understanding of ethnicity in contemporary African circumstances. Primordialists seem to gloss over the question of ethnicity and do not regard ethnic groups in Africa as being real (Ake 2000, p 94). Olorunsola (1972, p 4) cautions that the politics of ethnicity in Africa will not vanish on their own. If ethnic politics are ignored in the misguided hope that they will iron themselves out they will lead to disastrous outcomes, and if we merely paper them over they will prove fatal. Since this warning was issued Africa has seen some of the most horrendous acts of ethnic violence. The 1994 Rwanda genocide was probably the lowest point, proving that once ethnicity is mobilised it can easily lead to cataclysmic consequences. Instrumentalists argued that ethnic politics is made possible because of the twin attributes of manipulability and exploitability of ethnicity (Ake 2000, p 94).

One gap in the instrumentalists' theory is that it does not take account of the role played by the populace in ethnic politics in Africa. The rationale behind mass participation in ethnic politics is not easy to figure out. The thinking prevalent in modernisation theories that the masses exhibit a herd instinct so the political elite find them malleable does not stand up to scrutiny (Horowitz 1995, p104). Implicit in this thinking is that non-elites are victims of 'false consciousness' because they serve the interests of the political elite under the impression that those interests are theirs.

In Kenya the masses, through what Kanyinga (2001, pp 354-5) calls 'ethnicity from below', subject the political elite to pressure to locate itself strategically within the state so as to appropriate development and resources. This mode of ethnicity thrives on the logic of 'eating through one of our own'. Thus 'it is our turn to eat because another group has eaten becomes the organising slogan around which other considerations revolve'. As such, the politicisation of ethnicity is an enterprise that involves both the political elite and the masses.

Though it is tempting to read Kenya's politics through the instrumentalist prism, it is controversial to state that the masses in Africa are misled by politicians in pursuit of the pay-offs of the politics of extraction (Horowitz 1985, p 104). Horowitz (1985, p 105) asserts that it is difficult to reconcile this assumption that the masses follow the thinking of politicians uncritically, with compelling evidence from Africa and Asia indicating that non-elites are not ignorant about politics. Moreover, the masses in Kenya and elsewhere are not a homogenous entity and thus do not participate in politics in pursuit of identical interests. 
A constructivist approach to ethnicity debunks the existence of ethnic groups. Constructivists characterise those who insist on the reality of ethnic groups as people involved in ideological consciousness, which means the portrayal of ethnicity as a phenomenon which renders it susceptible to manipulation and mobilisation for the achievement of certain political and economic ends (Brown 2000, p 20; Ajulu 2002, p 252). The constructivist model understands ethnicity as socially constructed but not a fixed primordial identity. However, the primordial aspect cannot be entirely dismissed or it would not be possible for us to understand ethnic mobilisation (Young \& Turner 1985, p 140). As Horowitz (1985, p 105) argues, in order for the elites to deflect mass antagonisms on to other ethnic groups such a deflection must first resonate with mass sentiments, apprehensions, and aspirations.

According to the constructivist theory ethnicity is the result of a combination of dynamic and conflictual political, economic and cultural forces which are both external and internal to developing ethnic communities (Berman 1998). The constructivist understanding of ethnicity is premised on the view that ethnicity is an outcome of deliberate and conscious effort by both members of a given community and those from outside to define that community (Le Vine 1997, p 50).

Le Vine observes that the cognitive dimensions of ethnicity include not only ideas, perceptions, and attitudes about the self, the group, and others, but also the ascriptive boundaries that serve to distinguish one group from another. In Brown's analysis constructivist approaches suggest that national identity is constructed on the basis of an institutional or ideological framework which offers simple, and indeed simplistic, formulas of identity, and diagnoses of contemporary problems to otherwise confused or insecure individuals (Brown 2000, p 20).

Closely related to the instrumental approach is the situational one, according to which ethnic identities are not natural and instinctual to any given community but should instead be seen as resources deployed by politicians in pursuit of their common interests, which, in most cases, are political and economic (Brown 2000, p 13). Young (1985, p 139-40) argues that the effect of ethnicity on politics is contingent upon its instrumental dimension. Situationalism avers that people's responses change depending on the threats and options they face (Brown 2000, p 13).

The main thrust of a situational approach to ethnicity is that the boundaries of an ethnic group contract and expand in different situations. For instance, when opposed to another major group, an ethnic group's membership is defined inclusively, but when a situation arises in which the group projects internal divisions its membership tends to be restrictively defined (Bates 1983, p 165). As such, ethnicity is a fluid phenomenon, even though it may appear immutable in conflictual situations. Le Vine (1997, p 47) argues that group boundaries may shift as groups divide, merge, erode, aggregate, or redefine themselves over time. 
Young (1993, pp 21-25) believes the various approaches to ethnicity are enmeshed. Hence he argues that ethnicity involves three interactive dimensions: primordial, instrumental, and socially constructed. The elaborate quote below is apposite in capturing, although in a summation, his understanding of the concept of ethnicity:

Recent debate about ethnicity suggests that it involves three interactive dimensions: primordial, instrumental and socially constructed. Ethnic identity often involves deep emotional attachments to the group, supplies an internal gyroscope and cognitive map through which the social world is perceived, and histories of selfhood in a web of primordial cultural meanings. In everyday political and social interaction, ethnicity often appears in an instrumental guise, as a group weapon in the pursuit of material advantage; thus its activation is contingent, situational and circumstantial. Ultimately, all identities are socially constructed, a collective product of the human imagination ... Social identities are invoked, used, and rewoven in the myriad encounters of everyday life at both the individual and group level. Combining these three perspectives, we may conclude that ethnicity rests upon a singularly potent set of symbolic resources and affective ties, but operates in a fluid and changing way in the political arena. The units of identity are not themselves timeless, but evolve in social praxis.

Young 1994 in Le Vine 1997

The fluidity of ethnicity features prominently in literature in Africa. Thus Young (1976, p 5) argues that because the definition of groups is perpetually changing any theory of ethnic conflict must include change as a central issue.

\section{THEORY OF POLITICAL RELATIONSHIPS}

African politics largely thrives under a system of neopatrimonialism, although to varying degrees (Bratton \& Van de Walle 1997, p 61). Patrimonialism is defined as a type of government organised as an extension of the ruler's own household. The ruler makes no distinction between his own private property and that of the state. His rule over the territory is personal and arbitrary, without recourse to law or administrative predictability, as political authority is based on clientelism (Van de Walle 1994, p 131).

Analysts of African politics realise that attributes characteristic of patrimonial systems of rule have survived among the leaders of the new nation states, though 
patrimonial systems were thought to have disappeared from the African political scene. These leaders exhibit all the traits of medieval kings and sultans save for the titles. The concept of neopatrimonialism was born out of this striking similarity (Cooper 2002, p 96).

Patrimonialism is contrasted with rational-legal authority in which power is exercised in accordance with explicit legal structures specifying procedural rules and norms and serving to promote well defined public goals. In a rationallegal authority, there is a distinction between the public and private spheres and written laws and the bureaucratic institutions characterise the exercise of authority. Leaders are prevented from bringing their caprices and whims to bear on individuals' liberties and their property (Bratton \& Van de Walle 1997, p 62). It is through these lenses that the inclination towards arbitrariness without due regard for the rule of law which defined both the Kenyatta and Moi regimes could be interpreted. Under these leaders Kenya's Constitution was casually amended several times to entrench repression through the centralisation of power in the presidency (Mutua 2008; Ogot \& Ochieng' 1995). When Moi ascended to power his government hurriedly passed a motion in the National Assembly making Kenya a de jure single-party state (Widner 1994, p 58). Kenyatta ordered the arrest of dissenters who criticised his government on the floor of the National Assembly, which was a grave subversion of the rule of law, which accords members of the National Assembly immunity against remarks they make during parliamentary sessions.

Neopatrimonialism under Moi was exercised through a political elite drawn from his Kalenjin community. After a 1982 coup attempt Moi started building his own 'kitchen Cabinet', drawn largely from his community. It should be noted that the Kalenjin community comprises a mosaic of various sub-tribes and Moi's inner circle comprised power brokers from his Tugen and the neighbouring Keiyo communities of the larger Kalenjin ethnic group in the Rift Valley province (Ajulu 1993, p 4).

It is instructive to note, too, that Moi's Kalenjin power base was not cohesive either in a one-party state or in a multiparty democracy. He was invariably suspicious of the two most populous, most politically mobilised, and most economically developed Kalenjin subgroups, the Nandi and Kipsigis. Ironically, the Marakwet, hitherto considered part of the ruling troika together with the Keiyo and Tugen, posed a challenge to Moi's government in 1997 over perceived government bias towards the Pokot, another Kalenjin sub tribe, with which they were locked in a cattle-rustling dispute (Kagwanja 2001, pp 81-2).

As the principal patron Moi could not afford to build his own version of the one-party monolith on political carryovers from Kenyatta's era. He needed a retinue of new clients whom he could trust as he sought to consolidate his hold 
on power and check potential opposition. However, the widespread perception that the Kikuyu elite lost out during Moi's rule does not stand up to scrutiny in as much as it seems to have informed the community's opposition to Moi. In 1996, 18 years into Moi's rule, a highly confidential study of the makeup of the executive offices of the civil service showed that the Kikuyu, who comprise a fifth of the country's population, dominated the civil service (Morton 1998, p 212).

However, Moi, a consummate politician, was able to hide his intentions through a series of populist gestures aimed at endearing him to the masses (Ogot \& Ochieng' 1995). If there was any difference between Moi's and Kenyatta's presidencies it was that the former came across as an indefatigable leader, crisscrossing every nook and cranny of the country, ostensibly on inspections of and to launch development projects.

Moi invariably turned these tours into public rallies at which he made hortatory speeches (Morton 1995, p 170). This was a far cry from the almost reclusive and inaccessible Kenyatta, who hardly ventured into the rural areas, partly because of his age and partly because of hostility from communities such as the Luo (Khapoya 1980). During these forays Moi took the trappings of power into far-flung areas which had never seen the country's leaders at close quarters. Therefore, in a way, he succeeded in demystifying the institution of the presidency in Kenya but did not change its image as a predator and an ogre (Mutua 2008, p 40).

In as much as Moi banned ethnic welfare societies, which were springboards to political careers and vehicles for constituency building, because he viewed them as fostering ethnicity (Widner 1994, p 58), his entire presidency was characterised by the deft manipulation of ethnicity for political point scoring. He built his regime on a coalition of smaller ethnic communities and infused in them the fear of their numerically superior counterparts, encouraging them to cling together lest they be subdued. Moi, like Aguiyi Ironsi, one-time military strongman in Nigeria, ambitiously tried to ban or eradicate ethnicity while, ironically, adeptly exploiting it for political gain. Moi's contradictory approach to ethnic politics bears testimony to the resilience of the phenomenon in Kenya's polity (Osaghae 1994, p 6).

\section{ETHNIC POLITICS IN THE ONE-PARTY STATE}

In this section an attempt will be made to understand how ethnicity manifested itself under single-party rule in Kenya. Posner (2007) asserts that ethnicity is a strong criterion for the choice of candidates in both single-party and political pluralism. A distinction in the way in which ethnicity manifests itself in the two political systems lies in the dimension of cleavage politicians exploited.

Under the one-party system individuals tend to identify themselves in terms of ethnic identities which define them as members of small localised groups 
based on tribe, sub-tribe or clan. By contrast, in a multiparty setting political competition creates incentives for individuals to see themselves in terms of ethnic identities that define them as members of large blocks, usually based on religious, linguistic, or regional distinctions (Posner 2007).

Perhaps the greatest irony of Kenya's shift from single-party rule to political pluralism was that the then ruling party, Kanu, decided to capitalise on ethnicity in its bid to extract political mileage from competitive politics. This development must have rudely awakened most Kenyans to the recrudescence of ethnicity in the country's politics. Instead of the political landscape changing in consonance with the change in terms of freedom of the press, association, and free trade of ideas among competing political parties the parties that emerged camouflaged raw ethnicity (Apollos 2001). For instance, Kanu, led by Moi, became a party of Kalenjins and the minority tribes. Odinga dominated the FORD-Kenya party, which was mainly associated with the Luo and the Bukusu sub-tribe of the Luhya. The Kikuyu dominated two political parties - the Democratic Party (DP), led by Mwai Kibaki and the FORD-Asili Party, led by Kenneth Matiba (Apollos 2001).

Ethnicity found expression in Kenya's politics because most Kenyans felt alienated from the state, a lacuna whose provenance lay in the colonial period. The country came into being by means of an arbitrary process that paid no regard to the linguistic, cultural, or even religious identities of peoples who were lumped together in the political space designated as Kenya. Since the intention behind the formation of the state was administrative control and economic exploitation despotism was the hallmark of both the colonial governors and the political elite that succeeded them (Apollos 2001).

In the light of the above the nation-state project, not only in Kenya but also in many other African countries, was doomed from the start, since it was haunted by the fear of instability, disintegration and anarchy (Kagwanja 2003). Consequently, to most Kenyans the state was illegitimate and intruded on the lives of citizens without delivering the most basic of functions. The state also had a propensity for arbitrariness and selective application of the rule of law, often biased against people without means as well as against those who fell foul of the government of the day.

This lopsided legal framework resulted in discontent and disillusionment, if not outright revulsion, making it difficult to build a national democratic culture (Mutua 2008, pp 21-2). This created a disjuncture between the state and the members of ethnic groups who felt excluded from the benefits derived from control of the state. Consequently, there was an inclination towards an affective politics of ethnicity among Kenyans who were excluded either directly or indirectly from state largesse. 
Clampdowns on dissidents, a hallmark of single-party rule in Kenya, stymied the overt mobilisation of ethnicity, with the presidential behemoth providing a bulwark against opposition during Moi's rule. Moi promoted a political practice whereby ethno-regional delegations paid him what were euphemistically called courtesy visits at various state houses as well as at his home in Nakuru district (Mutua 2008, p 23).

Ethnic kingpins within his government invariably mobilised and corralled a mélange of grassroots leaders into sycophantically affirming their unstinting loyalty to him and to Kanu. These rituals bordered on personality cults in the sense that Moi was portrayed as the only Kenyan capable of ruling and as ordained to rule (Haugerud 1995). A politician within the ruling party deemed to be less enthusiastic about these exhibitions of showmanship and sycophancy risked placing his or her political career in jeopardy and being accused of insubordination.

Given the restrictive political space politicians found it difficult to whip up ethnic sentiment as a launch pad for their onslaught against the one-party citadel. Firstly, political rallies by opposition leaders were technically proscribed, since the process of acquiring a licence from the provincial administration was extremely laborious. The provincial administration was so beholden to the executive that it was impossible for the bureaucrats to grant permits for political rallies to politicians considered to be dissidents.

Secondly, until political liberalisation took place in 1991, there were no competitive presidential elections in which opposition leaders could participate. Both Kenyatta and Moi were invariably 're-elected unopposed', perhaps in keeping with their respective arrogated titles of 'founding father' and 'father of the nation'. Kibaki ascended to the presidency in 2002 at a time when the political space had been comparatively expanded, so politically savvy competitors were able to cobble together their own ethnic coalitions to stem advantages accrued to him by virtue of his incumbency (Mutua 2008, p 23).

Parliamentary elections in the single-party state were free to the extent that the Kanu inner circle allowed. For this reason Kanu hardly operated as an effective organisation save for its 'gate-keeping' function whereby civic and parliamentary candidates had to be selectively cleared by the party top brass before they contested elections (Berg-Schlosser 1989, p 125). The fact that the electorate was free to pick members of Parliament of their choice should not obscure the fact that the only candidates likely either to be re-elected or to make a maiden appearance in Parliament were those who Moi, the principal patron, and his acolytes supposed would display loyalty and not rock the party from within.

Throughout the era of the one-party state there was a high turnover of politicians, including Cabinet members, in the wake of general elections, but 
that was not a sign of democracy (Berg-Schlosser 1989, pp 126-7). In reality, the electorate simply endorsed those candidates Moi felt would do his bidding. The choreographed selections which passed for competitive elections at parliamentary and civic levels were intended to weed out of the system either politicians whose loyalty to Moi was deemed questionable or those perceived to have political clout.

Thus general elections ensured that, apart from Moi and a few members of his inner circle, the careers of most politicians were in a constant state of flux, resulting in them being preoccupied with their own political survival rather than with putting in place networks to rival Moi's.

At the height of the single-party tyranny Kanu was dormant between elections and would be reactivated at election times only to screen candidates in order to protect the fortunes of the elite rather than to mobilise voters (Khapoya 1980, p 19). The system thrived on corruption, patronage and rent-seeking. ${ }^{4}$

Through patronage, state and public resources are diverted into private hands and the system includes exchanges among the elite as well as the appropriation of public resources by ethno-regional and sectional interests (Haugerud 1995, p 46).

Rent-seeking is inherent in neo-patrimonial regimes. It operates in such a way that a ruler depends on a coterie of 'barons' to manage a political system (Van de Walle 1994, pp133-4). Typically, the ruler recruits these 'barons' from among political allies, personal friends, family, and even erstwhile enemies. In such a system prebends are derived from state agencies which collect government revenues through taxation, regulation and foreign aid, plus agencies whose role in regulating society provides the 'barons' with opportunities for rent seeking and fraud (Van de Walle 1994, pp133-4). Widner (1994, p 53) observes that the most lucrative avenues for rent-seeking in states in which formal institutions are weak include tariffs, credit rationing, foreign exchange rationing, domestic monopolies and monopsonies. Other means by which rent-seeking is executed include all manner of concessions such as tax waivers, loan cancellations and protection from criminal prosecution (Gyimah-Boadi 2007, p 29).

Political contests in Kenya were vicious because incumbents deployed patronage to interfere in the workings of state institutions. For instance, patronage played a crucial role in the manipulation of electoral institutions. The opposition accused Moi of exploiting incumbency to his advantage in the run-up to the 1992 elections after the advent of multiparty democracy. He had the power to announce

4 The exploitation of public office for economic advantage. Rent-seeking entails enrichment through political and bureaucratic positions, allocation of business and trading premises and licences, appropriation of land, contract inflation, kickbacks from multinational corporations, looting of parastatals, fraud and corruption (Ajulu 1995). 
the date of the elections as well as to appoint commissioners to the Electoral Commission of Kenya (ECK). Kibaki seemed to go several notches higher in this patronage-fashioned politics, focusing on winning the 2007 presidential elections by fair or foul means and then invoking state power and incumbency to fight off election challenges, a tactic that is, arguably, emerging as the greatest challenge to the consolidation of democratic tenets in Africa (Gyimah-Boadi 2007, pp 27-8).

Elections, particularly presidential elections, are a life and death affair in Kenya, which is why ethnic sentiment lies beneath the rhetoric of nationalism. It is not difficult to account for this state of affairs: loss of control of the central government in Africa does not simply mean a period in the political wilderness, it spells total economic disaster (Stone 1983, p 90). There is no other explanation for why Kibaki, soon after assuming office, embarked, as had his predecessors, on consolidating power by appointing cronies and political allies to strategic positions in his government and it is in this way that the apparently intractable challenges that have bedevilled Kenya's politics since the early 1990s may be viewed.

Moi vehemently opposed political liberalism, claiming that multipartyism would result in ethnic conflict and chaos and that the one-party state was appropriate for Kenya because it promoted unity among different ethnic groups. In his words political pluralism would result in people 'frying themselves in their own fat' (Apollos 2001). Whereas there is evidence that ethnic conflict, particularly rebellion, hampers democratisation, there is no simple connection between ethnic diversity and political instability or liberalisation/democratisation and ethnic conflict in Africa (Smith 2000).

The official position of Moi's regime was that Kenya's one-party democracy was grounded in traditional African culture, in which decisions are made by consensus as opposed to contest (Haugerud 1995, pp 39, 51). This argument was advanced by most of the first generation of African leaders, foremost among them being Tanzania's Julius Nyerere, who defended the single-party state on the grounds that it had its roots in Africa's past and its traditional form of democracy, which was based on discussion.

A number of scholars have debunked this position (Nabudere 1989, p 1). To analysts like Mutua (2008, p 40) the one-party state was a great disaster for Africa. Mutua posits that rather than being a model form of governance 'it was a demented bandit, looter and terrorist', notwithstanding the exemplary cases of Mauritius and Botswana. Nyong'o (1992, pp 2-3) also repudiates the contention of single-party proponents that Africa will benefit from that form of government.

However, both advocates of multipartyism and analysts of Kenya's politics agree that political liberalisation on its own will not engender political instability unless the ruling party instigates violence (Haugerud 1995, p 39). Thus the rhetoric on the connection between multipartyism and violence was interpreted as being 
aimed at discrediting proponents of multiparty pluralism, particularly the Gikuyu elite, who Moi and some of his more vocal acolytes accused of being driven by self-serving and sectarian interests in their purported quest for political reform (Haugerud 1995, p 39). If the manner in which a cabal of politicians in Kibaki's dispensation frustrated efforts to rewrite the Constitution was anything to go by we would deduce that among certain political elites in Kenya opposition to Moi was driven more by economics and ethnicity than by the need to reform the Kenyan state (Mutua 2008, p 77).

Both Kenyatta and Moi subtly manipulated ethnicity and it was only during the era of multipartyism that the genie of ethnic politics escaped from the bottle and prowled all over the country, leaving, in its wake, property destroyed and thousands maimed or murdered in ethnic clashes. Kenyatta deployed the provincial administration, which falls directly under the Office of the President, to exercise control in farflung areas away from the seat of government in the capital city, Nairobi. Moi used the ruling party, Kanu, to put his finger on the political pulse and repress opposition (Throup \& Hornsby 1998, p 37). Thus the period between 1985 and 1990 was characterised by attempts to construct a state in which politicians settled scores by using the party to harass and intimidate their opponents and, in extreme cases, have their rivals expelled from Kanu, thus freezing their political careers (Throup \& Hornsby 1998, p 37).

\section{MULTIPARTY POLITICS IN KENYA}

It is instructive to note that Kenya experimented briefly with a two-party system for a year after independence in 1963, when Kanu swallowed the Kenya African Democratic Union (Kadu), and between 1966 and 1969, when the Kenya People's Union (KPU) was in opposition (Mutua 2008, p 238; Khapoya 1980, pp 18-19). A 'Little General Election' was held in $1966 .{ }^{5}$ Save for the cited periods Kenya operated as a de facto one-party state until 1982, when it became a de jure oneparty state before reverting to political pluralism in 1991.

The major distinction between the way in which ethnicity manifested itself in one-party states and in multiparty democracies is that in the former the locus of political conflict is at the local constituency level, while in the latter it is at the level of the country as whole (Posner 2007).

True to Moi's prophecy of damnation ethnic clashes engulfed parts of the Rift Valley province, settled by communities considered 'foreign', and led to the loss of lives and property. Ironically, it was the Moi government that politicised the

5 The election was referred to in this way because it was held with the express intention of weeding out of the ruling party dissenting voices which had coalesced under Oginga Odinga's KPU (Ajulu 1995, pp 2-3). 
land issue, despite the fact that it was Moi who had facilitated the resettlement of some Kikuyu in the Rift Valley soon after independence, much to the chagrin of fellow Kalenjin politicians, particularly those from the Nandi and Kipsigis sub-tribes (Throup \& Hornsby 1998, p 29).

The targeted ethnic groups included the Kikuyu, Luo, Luhya and Kisii. Government complicity through the provincial administration was obvious, with administrators, through inaction, tacitly abetting the killing of innocent people. In certain cases they actually aided the marauding gangs which terrorised 'foreign' ethnic groups (Government of Kenya 1992; 1999).

The Moi government's behaviour after acquiescing to multiparty politics was typical of that of a weak state and from 1991 to 1998 politics in Kenya was commercialised, as patronage overtly held sway. During this period the Kenyan state could not perform its functions and the rule of law was beholden to Moi and his courtiers' caprices, resulting in a state of lawlessness in which the veneer of social cohesion flaked off.

A combination of these factors robbed the Moi government of the legitimacy to govern (Apollos 2001). The system skimmed the state for the benefit of a few members of the political elite from selected ethnic communities while the rest languished in economic and political limbo. The rule of law, or what had remained of it, collapsed as the police, in tandem with youth militias, cordoned off certain regions of the country, especially in the Rift Valley, and declared them Kanu zones, from which opposition was barred.

During this period the Kenyan taxpayer was swindled out of astronomical amounts of money by means of a scam dubbed Goldenberg. Through this scheme the Central Bank paid out money to individuals linked to Moi through a fictitious export compensation scheme involving phoney gold. The scandal could be viewed through the prism of patronage politics whereby the ruling elite was in desperate need of money in order to fight off an opposition onslaught. The money was intended to be used to disorganise the opposition and hire more loyalty at a time when Kanu's hold on power was under severe threat.

Though there is an argument that modernity heightens the politicisation of ethnicity there is a counter argument that social networks that link wealthier and better educated individuals across ethnic and local boundaries may lead to the emergence of political ideologies and practices which transcend the politics of prebendalism, clientelism and ethnicity (Haugerud 1995, p 43). The Kenyan case shows that the counter argument is constantly under severe pressure. Though Kenya has a significant middle class ethnic cleavages have perennially torpedoed attempts to reform the nation state. Since the opening of the political space in the early 1990s Kenya has witnessed the unsavoury side of ethnicity. So violent and unsettling has been the interface between ethnicity and pork-barrel politics 
that some analysts have asserted that, save for personality cultism, no power has exerted as much influence on political parties in Kenya since the advent of political pluralism as ethnicity (Mutua 2008, p 21).

The political elites, mostly from the Luo, Luhya and Gikuyu communities, mounted and sustained opposition to Moi's authoritarianism. However, they opposed Moi's highhandedness for different reasons. The Kikuyu elite was driven by nostalgia for the privileges they had enjoyed under Kenyatta, while the Luo and sections of the Luhya felt excluded under Moi, just as they had been under Kenyatta (Mutua 2008). These differences were nonetheless subsumed in a global quest for multiparty democracy. Their clamour for political change was so disparate that when Kibaki succeeded Moi some of Moi's most ardent critics, most of whom had built their political careers on attacking him, embraced the very structures Moi had exploited to abuse power,.

Most political parties in Kenya were in the grip of tribal barons who doubled as the party's financiers and proprietors. Parties have no membership save for supporters who associate with them for purely ethnic reasons, prompting Mutua (2008, p 22) to describe most of them as reservoirs of 'ethnic nativism'. He further observes that demagoguery perennially held sway during electioneering periods as party leaders moved around the country disseminating ethnic-based political myths, distorted histories, and perceived grievances against other groups.

In an attempt to obfuscate the raw nature of ethnic politics in Kenya crossethnic alliances, for example, pairing presidential and vice-presidential candidates of different ethno-regional origins, are constructed (Haugerud 1995, p 43). The 1992 general elections showed the futility of such alliances as manifested in a faction of the Forum for the Restoration of Democracy (Ford) parties. Whereas Ford-Asili's Kenneth Matiba, a Kikuyu, was able to garner substantial votes from the Luhya community by dint of having a running mate, Martin Shikuku, from that community Ford-Kenya's Oginga Odinga's presidential bid fared dismally in Kikuyu dominated areas, including his running mate Paul Muite's own constituency (Mutua 2008, p 87).

In the 1992 general elections, the first such competitive polls since Kenya's return to political pluralism, what was forecast as a landslide opposition victory foundered on the shoals of ethnicity. In the run-up certain sections of the Kikuyu political elite allegedly convinced Matiba, at the time admitted to a London hospital, to run for president because they could not countenance Odinga, a Luo, leading Kenya because he was presumed to be uncircumcised (Badejo 2006, p 165). Matiba's entry into the presidential race led to the bifurcation of the Ford party.

With the splintering of that once formidable opposition party the opposition's chance of dislodging Moi went up in smoke. An assessment of both presidential and parliamentary votes in that year clearly indicates the triumph of ethnic 
ideology over political liberalism (Mutua 2008, p 87). Southall (1998) also located the inability of creating a common political front against Moi in 1992 in what he called 'the minutiae of ethnic politics and the enmeshing web of patronageclient relations and the realization by individual politicians that membership of the political class brings access to the spoils system'. However, Moi's re-election could not be reduced to a simple case of ethnic factionalism within the opposition. Three basic explanations were advanced in the wake of the election results: that Moi and Kanu had rigged them; that Moi and Kanu had won; that the opposition had lost because it had split up. All three contain some truth (Holmquist \& Ford 1994, p 8).

In 1997 Moi easily won his second and last term in office because once again opposition leaders demonstrated that they had learnt nothing from the 1992 defeat and, for the second time, political egos stood in the way of opposition unity. Each of Kenya's five major ethnic groups fielded a presidential candidate, which made it easier for Moi to sail through by scooping votes from almost every ethnic group barring the Luo and Kikuyu communities, from which he was virtually locked out.

The constellation of smaller ethnic groups remained loyal to Moi and, with significant votes from the Luhya community, the second-largest in the country, Moi was home and dry. In the wake of yet another routing by the ruling party it became patently obvious that nothing short of unity would help the opposition wrest power from Moi's clutches.

\section{THE 2002 GENERAL ELECTIONS AND COALITION POLITICS}

In 2002 Kenya held watershed elections that were seen as a mark of transition from arbitrary and personalised leadership to the institutionalisation of governance in constitutional structures. The general elections were also billed as a defining turn in Kenya's political history in the sense that it was expected that they would mark a break from autocracy, impunity, ethnic and rent-seeking politics to a new dispensation characterised by national cohesion, respect for the rule of law, accountability and a general reorientation of Kenya's politics. Hence the phrase 'second liberation', the first having been from colonialism. According to Furley (1995, p 15) the phrase 'second liberation', as applied to African politics, denoted the removal of the old generation of leaders in the early 1990s.

The opposition coalesced under the aegis of the National Rainbow Coalition (NARC) and successfully defeated Moi's anointed successor, Uhuru Kenyatta, the late Jomo Kenyatta's son. NARC was driven by a personal vendetta against Moi for having bypassed them in settling for Kenyatta, a political parvenue. Devoid of any ideological anchor, the grouping lowered the bar: any presidential candidate 
with a realistic chance of defeating Kenyatta was acceptable. Therefore it would be a mistake to regard NARC as reform minded.

It was, however, unequivocal about its mission, which was to win the election and form a better government. Whereas the first part of the mission was accomplished with ease, the formation of a better government proved hopelessly elusive and the coalition grappled with the problem until it collapsed under the weight of constant wrangling, bickering and factionalism. Some of its more candid members stated that the coalition was fired up by a single objective - to remove Kanu from power - and once that was achieved it became mired in infighting (Kadima \& Owuor 2006, p 204).

Against this backdrop the NARC coalition may be analysed within the theoretical framework of coalition politics, known as office-seeking, which assumes that the main goal of political parties is to gain access to power. To proponents of this thesis government formation is a zero-sum scenario in which Cabinet portfolios are the pay-off (Kadima 2006). Office-seeking, according to Kadima (2006, p 8), applies in many African countries where securing posts in government, Parliament, parastatals or the diplomatic corps is extremely competitive in the context of general impoverishment and coalition-building serves as an avenue of access to such positions. However, unlike the situation in Western Europe, where coalitions are formed after elections in the context of the proportional representation electoral system, in Kenya, alliances were formed before the 2002 elections (Kadima 2006, p 8).

Contrary to popular belief Kibaki was not popularly elected in 2002; his ascendancy to the presidency was less the result of a convergence of ideological positions and synthesis of programmes of action among NARC's affiliate parties than of a rickety union of ethnic factions. Kibaki's fellow opposition leaders, with support circumscribed within their ethnic constituencies, opted to place their own presidential ambitions in abeyance and backed him in the hope that he would reciprocate with plum posts in an envisaged collegial government (Daily Nation 23 September 2007).

According to Kadima (2006, p 10) a party coalition is defined as the coming together of a minimum of two political parties for a certain period, in pursuit of an agreed set of common goals to be reached by means of a common strategy, joint actions, the pooling of resources and the distribution of possible subsequent pay-offs. In both the 1992 and 1997 elections the combined votes for the opposition totalled more than those for Kanu and Moi (Hornsby 2001, pp 135-204).

To avoid yet another defeat because of fragmentation opposition parties built a coalition in order to consolidate their voting blocs. NARC settled for Kibaki as its presidential candidate purely on ethnic grounds. Kanu, or rather Moi, had chosen Kenyatta, a Kikuyu, so Kibaki, another Kikuyu, was chosen in order to 
split the populous Kikuyu vote, since the other major ethnic groups were solidly in the NARC fold.

It may be true that some of NARC's leading members were opportunists pursuing self-serving interests but the NARC manifesto indicated that the coalition had certain objectives, among them ending corruption, transforming the country politically and economically, providing free education and empowering the people. Others were to change the Constitution within 100 days of taking power and to establish a parliamentary system of government with a ceremonial head of state and an executive prime minister (Kadima \& Owuor 2006, p 204).

Apart from free primary-school education, which NARC introduced soon after it assumed power, the rest of its pledges were abandoned (Kadima \& Owuor 2006, p 204). Rather than the Kibaki government delivering on a new constitution as promised, it became a stumbling block to the realisation of this aim, just as Moi had been (Human Rights Watch - HRW - 2002, p 9). The government watered down a draft constitution which had taken four years to write and had cost astronomical amounts of tax payers' money. The bastardised draft, popularly known as the Wako Draft, named after the country's attorney general, was eventually rejected in a referendum in 2005, which polarised the country along ethnic lines (European Union Election Observer Mission 2008; Mutua 2008).

Kenyans ushered in multipartyism with single-party structures intact and a single-party mentality among most political leaders. Kibaki, for example, who served Kanu almost his entire adult life, rising to the vice-presidency of the country, was a zealous architect and defender of a single-party behemoth (Badejo 2006, pp 91, 92, 161). It is this 'illusion of change' (Hornsby 2001, p 157) that may account for the seemingly intractable and convoluted reform process in Kenya. Apart from amendments to the Constitution in the mid-1990s, which made provision for more political parties (HRW 2002, p 6), the document remained pretty much as it was under one-party rule.

The twin issues of devolution of power and resource distribution were not constitutionally redressed and it was these issues that turned ethnicity into such an incendiary phenomenon. Comprehensive constitutional reforms to redress the disproportionate concentration of powers in the presidency had not featured prominently among the demands of Kenya's opposition parties in the early 1990s. However, after they were unable to unseat Moi in 1992 and 1997, the opposition realised that the matter deserved priority attention, for the Constitution gave the incumbent an edge over his opponents.

In the 2002 elections the seemingly impossible happened. For instance, the Luo, a community whose son, Oginga Odinga, differed ideologically with Kenyatta, resulting in the former's political ostracism, overwhelmingly voted for Kibaki, a Kikuyu, a move that put paid to Moi's succession game plan, which had 
based Kenyatta's chance of victory on the presumed inability of the Luo to vote for a Kikuyu because the two communities were widely perceived to be mutually antagonistic. The Luhya, a community known as politically liberal in the sense that they had never voted as a bloc, almost unanimously cast their votes for Kibaki, who they had rejected during his presidential bids in 1992 and 1997.

Kibaki disregarded an offered pre-election power-sharing agreement and marginalised the Liberal Democratic Party (LDP) allies of the coalition. Consequently, his administration acquired an ethno-regional bias, with power concentrated among a cabal of individuals drawn from the Mount Kenya region, home to the Kikuyu, and their close cousins, the Meru and Embu, hence the sobriquet 'the Mount Kenya Mafia' (Nasong'o \& Murunga 2007, p 9). Kenyatta had the Kiambu Mafia, Moi the Kabarnet Syndicate (Ajulu 2002, p 262). Bratton \& van de Walle $(1997, \mathrm{p} 8$ ) had Kenya in mind when they pointed out that even after political transitions in Africa the new rulers were often drawn from the same social and political classes as their predecessors, including an ageing generation of old-guard politicians who had served previous regimes.

Kibaki was accused of perpetuating ethnicity as the focal point of governance in Kenya by appointing a disproportionate number of members of the Kikuyu and Meru communities to prominent positions in the Cabinet, state corporations, and the civil service. He squandered an opportunity to dispel the belief held by most ethnic groups that the Kikuyu elite was incurably mendacious and had no regard for the country's ethnic diversity. There were those who believed that the influence of ethnicity in Kenya's politics was neutralised once Kibaki's candidature received overwhelming support from the Luo, a community considered to be the Kikuyu nemesis. This misconception was, perhaps, borne out of the hysteria of the 2002 elections.

Firstly, Kibaki had ascended to power courtesy of ethnic manoeuvring. In Kenyan parlance it was called ethnic calculus or arithmetic and to expect him to rise above a phenomenon of which his presidency was a creature was stretching credulity too far.

Secondly, his political career did not mark him as a reformer. In fact, NARC was similar to Kanu in everything but name. Its top decision-making organ, christened 'The Summit' (Badejo 2006, p 351), was composed mostly of individuals who staged a court rebellion against Moi over the latter's succession plan and who were dyed-in-the-wool single-party apologists without any iota of reform credentials. NARC was a bandwagon, some of whose occupants, recasting themselves as reformers, were implicated in gross economic crimes and human rights abuses, including the politically motivated ethnic clashes that rocked the country in the early 1990s (HRW 2002).

Thirdly, Kenyans from other ethnic groups did not vote for Kibaki because 
his policies resonated with their aspirations. After all, he had run for president twice without success. The question was: what, in 2002, made him appeal to those communities that had previously not considered him capable of leading the country? If one were to aggregate the reasons why Kenyans voted for Kibaki at the time, one might surmise that they were partly the result of Kenyans' frustrations with what they considered to be Moi's misrule and their opposition to what they saw as his intention to institutionalise the Kenyatta dynasty. They were also desperate for unity among opposition parties, hoping that would herald change. But neither they nor the opposition had the time or the capacity to identify the ideal person or group of persons to deliver that change.

Thus one could argue that the quest of Kenyans for institutional and constitutional reforms led them to vote overwhelmingly for Kibaki. The HRW report released in the wake of the post-2007 election violence argued that there was a need to overhaul the entire system of governance in order to address deeprooted problems that had either been ignored or exacerbated by Kenya's successive governments. The report cited ownership and allocation of land, the Constitution, impunity for corruption, and the organisation of political violence as the most pressing issues at the core of Kenya's post-colonial crisis (HRW 2008, p 12).

The NARC coalition collapsed when differences between the constituent political parties, that is, the LDP and the National Alliance Party of Kenya (NAK), proved irreconcilable. In sync with history the fallout assumed a Luo-Kikuyu dichotomy. In the wake of the 2005 referendum defeat Luo Cabinet members and colleagues who mobilised Kenyans against the draft constitution were axed from the government. To shore up support for his government Kibaki co-opted Kanu loyalists in spite of some of them having been involved in the excesses of Moi's regime, including ethnic clashes (Government of Kenya 1992).

The reason why any reform of Kenya's polity had proved such a Sisyphean undertaking is that one of the flaws attendant on the country's re-entry into multiparty politics was that the struggle for reform was largely conducted through forums such as the media, public rallies and, more tragically, through violent ethnic clashes (Ndegwa 1997).

\section{THE POST-2007 ELECTORAL AND POLITICAL CRISIS}

Kenya's near implosion after the bungled 2007 presidential election was a phenomenon many analysts had predicted, given the consistently perilous political trajectory of the country since Kenyatta's rule (Khadiagala 1995; Southall 1998). The image Kenya had acquired prior to December 2007 of 'an island of peace in a sea of turmoil' was a mirage, bearing in mind the country's history (HRW 2002, p 3). Rather its post- election violence confirmed a pattern in Africa's 
politics established in countries like Togo, Côte d'Ivoire, Burundi, Sierra Leone, and Congo Brazzaville (Gyimah-Boadi 2007, pp 27-28).

The three major political parties competing in the 2007 election were incumbent Mwai Kibaki's Party of National Unity (PNU), Raila ${ }^{6}$ Odinga's Orange Democratic Movement (ODM) and Kalonzo Musyoka's Orange Democratic Movement-Kenya (ODM-K). The rest were fringe parties. Uhuru Kenyatta opted to support Kibaki, since, as a Kikuyu, he knew fellow Kikuyu would not choose him above the incumbent, who was a fellow tribesman. It would have been risky for the Kikuyu to try to replace one of their own in a highly competitive presidential election. Kenyatta chose to bide his time and wait for 2012, well aware that with Kibaki ineligible to stand for a further term he was likely to inherit the Kikuyu voting bloc intact.

There was an assumption among ethnic supremacists, particularly within the PNU, that a Luo would never be elected president. In fact, Musyoka latched onto this stereotype in his insistence that he was the best bet for a combined opposition. He jumped ship and appropriated the ODM-K and, for a while, appeared to have pulled the rug from under the feet of Raila and his allies. His moment of political genius was ephemeral, however, because his erstwhile colleagues took back the initiative when they were handed back the ODM, a party that had been hurriedly registered by some obscure individuals after it was successfully used to defeat the government in the 2005 referendum. The intention was to deny the opposition the word 'orange', which had become such a brand in Kenya's politics. Kalonzo bolted when he realised that Raila would rather have the myth of 'Luo unelectability' tested at the ballot than smother his presidential ambitions on the strength of an argument mired in naked ethnic chauvinism.

There are those who bizarrely argued that Raila's natural political home was in the opposition because of his track record as a seasoned oppositionist. People who hewed to this position asserted that if he became president there would be no one to check the government of the day. If the 2007 election shattered any myth it was that no Luo could be elected president. The fact that Raila lost the presidency because of a flawed counting process, courtesy of a compromised electoral commission, was, in a way, a huge psychological boost for Kenya's collective psyche in the sense that it was no longer tenable for anyone to assert that a Luo could not occupy the highest office in the land. However, what is of equal concern is that the fact that Raila 'came within a whisker of winning the presidency"

6 Raila Odinga is often referred to by his first name in order to differentiate him from the senior Odinga, since he is considered to have carved a niche for himself in Kenya's politics that is distinctly different from his father's, though, like his father, he is a seasoned oppositionist.

7 Raila and most supporters of the ODM were convinced he had won but that the incumbent had stolen the election through misuse of the state machinery. 
showed that only members of large ethnic groups in Kenya are perhaps electable (Mutua 2008, p 248).

Though Mutua concedes that the presidential election was flawed, particularly at the counting stage, there are those who would not hesitate to contest his evasive phraseology, which seems to be consistent with the systemic and pervasive mendacity that weighed down Kenya's post-colonial state. In certain quarters it is believed that victory was blatantly stolen from Raila and the ODM.

According to the United States's non-partisan democracy building organisation, the International Republican Institute (IRI), Raila finished six points ahead of Kibaki in the exit poll (McClatchy Newspapers 8 July 2008; McClatchy News Service 9 July 2008; The Standard 10 July 2008). Furthermore, the electorate voted out more than 20 of Kibaki's Cabinet ministers, including his vice-president and leaders of political parties that formed his re-election coalition. Coupled with the fact that the ODM had the highest number of parliamentary and civic seats it was difficult to contend that the Kenyan voter was sophisticated enough to isolate a presidential candidate from his party. For instance, Raila's ODM won 99 parliamentary seats to Kibaki's PNU's 43 (Mutua 2008, p 244). However, the bifurcation of the ODM camp between Musyoka and Raila made the contest too close to call. Had the ODM faced the elections as a single entity, as it did the 2005 referendum, the post-election impasse might not have occurred.

As in the previous multiparty elections ethnic factionalism ensured that the opposition could not hold together. After a hurriedly convened swearing-in ceremony Kibaki appointed Musyoka as his vice-president, with the intention of forming a Central-Eastern Bantu alliance against the Luo-Luhya-Kalejin Western Kenya ODM group, hence splitting the country down the middle (Mutua 2008, p 250).

For the umpteenth time the elections brought to the fore the ethnic incubus in Kenya's voting patterns, with the three major presidential candidates drawing support from their ethnic strongholds. Kibaki retained the Mt Kenya constituency of the Kikuyu, and the linguistically and culturally related Embu and Meru, the bloc on which he launched his presidential bid in 1992 and which had solidly rallied behind him ever since.

Raila drew his following from the Luo, Luhya, Kalenjin and other smaller ethnic groups in the Rift Valley, North Eastern and Coastal provinces, which he cobbled together under an umbrella called the Pentagon - the topmost decisionmaking organ of the ODM, which drew representation from almost all the party's ethno-regional components. Raila demonstrated that he was a master of Kenya's politics in the sense that he knew that in the country's ethnically fractious political landscape the way to craft a winning formula was by cobbling together a coalition 
comprising leaders of the major ethnic groups - a strategy NARC employed successfully against Kanu in 2002 (Mutua 2008, p 240). Musyoka's bedrock was the Kamba community. Although he had a running mate from the Luhya community he fared abysmally among the Luhya. Beneath the patina of an issue-informed election lay raw ethnicity, on which the three presidential contestants hinged their campaigns and their hopes of ascending to the presidency.

Perhaps more than anything else the elections proved that Kenya's nation state is extremely fragile. The 2007 debacle was a strong indictment of the postcolonial leadership for having perilously gambled with ethnicity among Kenya's 40-odd disparate ethnic groups. The near implosion of the country was clear confirmation that there is a great deal of nation-building still to do (Mutua 2008, p 250). The Kenyan polity needs to break a culture of impunity, promote the equitable distribution of resources and stem neo-patrimonial politics. The place to start would be constitutional reform, though that must be accompanied by an ideo-political renaissance among the political elite.

On a positive note, the ODM wing of the opposition, through Raila, attempted to pull the campaign out of the morass of bland, vacuous and incoherent pledges that had characterised previous multiparty campaigns, which revolved vaguely around a supposed commitment to the rule of law, human rights and economic reform. The ODM stumped the entire country, appealing directly to and connecting with the masses the much-vaunted economic boom of Kibaki's first term in office did not reach.

Odinga consistently returned to the vexed question of uneven development among communities and regions with his pledge to decentralise the government - a radical departure from previous election campaigns in which raw ethnicity was the overriding factor (Mutua 2008, pp 249-50). In addition, he pledged to revamp infrastructure as the lifeblood of economic development.

However, even what appeared to be issue-oriented politics had ethnic overtones. The ODM coalition, which was almost a replica of the Orange brigade which had mobilised Kenyans in a referendum against a draft constitution in 2005, was intended to isolate the Kikuyu community. Raila said as much, both during the referendum campaign and during the 2007 election campaign, in which he implored the Kikuyu not to isolate themselves from the rest of the Kenyan people (Mutua 2008, p 242).

Democracy, which underscores individual liberties, gave a people the inalienable right to vote the way they liked and it would be a travesty either to take retributive measures against an individual or community for voting in a particular way or to urge them to ally themselves with other communities if they do not wish to do so. 


\section{CONCLUSION}

This paper has attempted to trace ethnic politics in Kenya from the colonial period to the advent of political pluralism. The theoretical section provides a lens through which to interpret the apparent ethnic incubus in Kenya's politics. If we juxtapose the single-party state with the multiparty era we realise that whereas ethnicity played an overarching role in Kenya's politics in both phases the difference lies in the extent of the ethnic cleavage it induced.

During the time of one-party rule both Kenyatta and Moi deftly manipulated ethnicity for political as well as economic ends. However, state repression against dissent made it difficult for countervailing forces to mobilise around ethnicity in order to challenge the government of the day.

With the opening up of the political landscape after the decriminalisation of multipartyism political mobilisation and voting patterns took on an ethnic dimension, with resultant cyclical ethnic skirmishes in the run-up to or in the wake of general elections. The high watermark of this perilous brand of politics put Kenya's nation state to severe test after the ECK handled the 2007 presidential elections so unprofessionally.

The paper advances the argument that ethnicity per se is not inimical to national solidarity and cohesion, in fact, it could be a boon in cases where certain ethnic groups genuinely feel marginalised and exploit ethnicity to hold the state accountable and demand an equitable distribution of national resources. What is damaging to Kenya's social fabric is the politicisation of ethnicity by wily and demagogic leaders who stump the country whipping up ethnic sentiment by appealing to stereotypes in a bid either to wrest power or to maintain it.

If we depart from the premise that ethnicity is largely a social construct we can confidently opine that it is possible to put in place mechanisms that prevent people's ethnic diversity from threatening their very survival. As a prerequisite for viable politics Kenya must begin with fundamental constitutional reforms, which must include the strengthening of Parliament and other institutions of accountability.

This will not be an easy exercise, bearing in mind that attempts to rewrite the Constitution have perennially fallen prey to sectarian interests, which, as the 2005 referendum showed, often took on an ethnic dimension. In fact, the outcome of that referendum, in which Raila led renegade government ministers in rejecting the draft constitution, was a dress rehearsal for the 2007 general elections. Ethnic voting patterns exhibited during the referendum almost replicated themselves in the 2007 polls.

Kenya urgently needs to revise its electoral system, preferably to include some element of proportional representation and a move away from the simple 
majority, first-past-the-post system (Southall 1998; Mutua 2008, pp 2-3). Such reforms will reduce the stakes during presidential elections. The polity needs a concatenation of reforms as the challenges bedevilling it are legion and there are groupings which have vested interests in the status quo. All in all, it is instructive to analyse the 2007 presidential election against a background of a constitutional structure which gave the sitting president all the aces, making it almost impossible for it to be credible.

\section{REFERENCES}

Ajulu, R. 1992. 'Kenya: The Road to Democracy'. Review of African Political Economy 53.

1993. ‘The 1992 Kenya's General Elections: A Preliminary Assessment'. Review of African Political Economy 56.

1995. 'The Transition to Multi-partyism in Kenya: the December 1992 Presidential, Parliamentary and Municipal Elections'. Working Paper. Grahamstown: Rhodes University.

2002. 'Politicised Ethnicity, Competitive Politics and Conflict in Kenya: A Historical Perspective'. African Studies 61.

Ake, C. 2000. The Feasibility of Democracy in Africa. Dakar: CODESRIA.

Apollos, M. 2001. 'Ethnicity, Violence and Democracy'. Africa Development XXVI (1 \& 2). Available online: www.codesria.org.

Atieno Odhiambo, E. S. 2002. 'Hegemonic Enterprises and Instrumentalists of Survival: Ethnicity and Democracy in Kenya'. African Studie 61(2).

Badejo, B. 2006. Raila: An Enigma in Kenya's Politics. Nairobi: Yintab Books.

Bates, R. 1983. 'Modernization, Ethnic Competition and the Rationality of Politics in Contemporary Africa'. In D Rothchild \& V Olorunsola (eds). State Versus Ethnic Claims: African Policy Dilemmas. Boulder: Westview Press.

Bengal, S. 2008. 'Wrong candidate won in Kenya, exit poll indicates'. McClatchy News Service, 9 July. Available online: http: www.iri.org/newsarchive/ 2008/2008-0709-News-MiamiHerald-Kenya.asp.

Berg-Schlosser, D. 'Democracy and the One-Party State in Kenya'. In D Nabudere \& P Meyns (eds). 1989. Democracy and the One Party-State in Africa. German Association of Political Science.

Berman, B. 1998. 'Ethnicity, Patronage and the African State: The Politics of Uncivil Nationalism'. African Affairs 97(388).

D Eyoh \& W Kymlicka. 2004 Ethnicity and Democracy in Africa. Oxford: James Currey. 
Bienen, H. 1983. 'TheState and Ethnicity: Integrative Formulas in Africa'. In D Rothchild \& V Olorunsola (eds). State Versus Ethnic Claims: Africa Policy Dilemmas. Boulder: Westview Press.

Bratton, M \& N van de Walle. 1997. Democratic Experiments in Africa: Regime Transitions in Comparative Perspective. Cambridge: Cambridge University Press.

Brown, D. 2000. Contemporary Nationalism Civic, Ethnocultural \& Multicultural Politics. London and New York: Routledge.

Chazan, N, P Lewis, R Mortimer, D Rothchild \& S Stedman. 1999. Politics and Society in Contemporary Africa. London: Lynne Rienner Publishers.

Cooper, F. 2002. Africa Since 1940. Cambridge: Cambridge University Press.

Elischer, S. 2008. 'Ethnic Coalitions of Convenience and Commitment: Political Parties and Party Systems in Kenya'. Working paper. German Institute of Global and Area Studies 68. Available online: www.giga-hamburgde/ workingpapers

European Union Election Observer Mission. 2008. 'General Elections 27 December 2007'. ec.europa.eu/external_relations/human_rights/eu_election_ass. observer/kenya07/final_report.en.pdf

Friedman-Sabar, G. 1997. 'Church and State in Kenya, 1986-1992: The Churches' Involvement in the "Game of Change"'. African Affairs 96(382).

Furley, O (ed). 1995. Conflict in Africa. London: I. B. Tauris Publishers.

Government of Kenya. 1992. Report of the Parliamentary Committee to Investigate Ethnic Clashes in Western and other Parts of Kenya. The Kiliku Report. Nairobi: Government Printer.

2008. Commission of Inquiry into the Post-election Violence. The Waki Commission. Nairobi: Government Printer. Available online: www.nation.co.ke/blob/view//483378/data/46260/-/4cocat/-/WakiReport.pdf

Gyimah-Boadi, E. 2007. 'Political Parties, Elections and Patronage: Random Thoughts on Neo-Patrimonialism and African Democratization'. In M Basedau, G Erdmann \& A Mehler (eds). Votes, Money and Violence: Political Parties and Elections in Sub-Saharan Africa. Pietermaritzburg: University of KwaZulu-Natal Press.

Haugerud, A. 1995. The Culture of Politics in Modern Kenya. Cambridge: Cambridge University Press.

Himbara, D. 1994. Kenyan Capitalists: The State and Development. Nairobi: East African Educational Publishers.

Holmquist, F \& M Ford. 1994. 'Kenya: State and Civil Society and the First Year after the Election'. Africa Today 41(4).

Hornsby, C. 2001. 'Election Day and Results'. In M Rutten, A Mazrui \& F Grignon (eds). Out for the Count: The 1997 General Elections and Prospects for Democracy in Kenya. Kampala: Fountain Publishers.

Horowitz, D. 1985. Ethnic Groups in Conflict. Berkeley: University of California Press. Human Rights Watch. 2002. Kenya's Unfinished Democracy: A Human Rights Agenda for 
the New Government 14(10). Available online www.hrw.org/reports.org/2002/ kenya2/

2008. Ballots to Bullets: Organized Political Violence and Kenya's Crisis of Governance 20(1).

Hyden, G. 1983. 'Problems and Prospects of State Coherence'. In D Rothchild \& V Olorunsola (eds). State Versus Ethnic Claims: African Policy Dilemmas. Boulder: Westview Press.

Kadima, D (ed). 2006. The Politics of Party Coalitions in Africa. Johannesburg: EISA/ Konrad Adenauer Stiftung.

Kagwanja, P. 2003. ‘Globalizing Ethnicity, Localizing Citizenship: Globalization, Identity Politics and Violence in Kenya's Tana River Region'. Africa Development XXVIII (1 \& 2). Available online: www.codesria.org

'Politics of Marionettes: Extra-legal violence and the 1997 Elections in Kenya'. In M Rutten, A Mazrui \& F Grognon (eds). 2001. Out of the Count: The 1997 General Election and the Prospects for Democracy in Kenya. Kampala: Fountain Publishers. Kadima, D \& F Owuor. 2006. 'The National Rainbow Coalition'. In D Kadima (ed). The Politics of Party Coalitions in Africa. Johannesburg: EISA/Konrad Adenauer Stiftung.

Kanyinga, K. 1998. 'Contestation over Political Space: The State and Demobilisation of Opposition Politics in Kenya'. In O A Olukoshi (ed). The Politics of Opposition in Contemporary Africa. Uppsala: Nordiska Afrikainstitutet.

2001. 'Mix-and-Match Parties and Persons: The 1997 General Elections in the Meru and Embu Regions of Kenya'. In M Rutten, A Mazrui \& F Grognon (eds). Out of the Count: The 1997 General Election and the Prospects for Democracy in Kenya. Kampala: Fountain Publishers.

Kasfir, N. 1976. The Shrinking Political Arena: Participation and Ethnicity in African Politics with a Case Study of Uganda. Berkely: University of California Press.

Katz, S. 1985. 'The Succession of Power and the Power of Succession: Nyayoism in Kenya'. Journal of African Studies 12(3).

Khadiagala, G. 1995. 'Kenya: Intractable Authoritarianism'. American Political Science Review in School of Advanced International Studies Review: A Journal of International Affairs XV(2).

Khapoya, V. 1988. 'Moi and Beyond: Towards Peaceful Succession in Kenya?' Third World Quarterly 10(1).

Kitching, G. 1980. Class and Economic Change in Kenya: the Making of an African PetiteBourgeoisie. New Haven: Yale University Press.

Le Vine, T. 1997. 'Conceptualising "Ethnicity" and "Ethnic Conflict": A Controversy Revisited'. Studies in Comparative International Development 32(2).

Leys, C. 1975. Underdevelopment in Kenya: The Political Economy in Neocolonialism 19641971. London: Heinemann. 
Lonsdale, J. 2004. 'The Dynamics of Ethnic Development in Africa'. In B Berman, D Eyoh \& W Kymlicka (eds). Ethnicity and Democracy in Africa. Oxford: James Currey.

2008. 'Kenya: ethnicity, tribe, and state'. Open Democracy Online: www. opendemocracy.net

Mamdani, M. 1996. Citizen and Subject: Contemporary Africa and the Legacy of Late Colonialism. Kampala: Fountain Publishers.

McClatchy Newspapers. 2008. 'Kenya's president lost disputed elections, polls show', July. Available online: www.iri.org/newsarchives 2008.asp

Morton, A. 1998. Moi: The Making of an African Statesman. London: Michael O'Mara Books Ltd.

Mutua, M 2007. 'Ethnicity the bane of Kenyan politics'. Daily Nation 23 September. Available online: nationmedia.com/dailynation/printpage. asp?newsid $=107037$ 2008. Kenya's Quest for Democracy: Taming the Leviathan. London: Lynne Rienner Publishing.

Nabudere, D \& P Meyns (eds). 1989. Democracy and the one-party state in Africa. German Association of Political Science.

Nabudere, D. 1989. 'The One-party State in Africa and its Assumed Philosophical Roots'. In D Nabudere \& P Meyns (eds). Democracy and the One-party State in Africa. German Association of Political Science.

Nasong'o S and Murunga G "Prospects for Democracy in Kenya."In Nasong'o S. and Murunga G. (eds) 2007. Kenya The Struggle for Democracy, Dakar, CODESRIA Books.

Nation Daily. 2002. 'The end of an era - as the curtain falls on Daniel arap Moi's 24year rule, a special report on the life and politics of Kenya's second president', 24 December.

Ndegwa, S. 1997. 'Citizenship and Ethnicity: An Examination of Two Transition Moments in Kenya'. The American Political Review 91(3).

Nnoli, O. 1995. Ethnicity and Development in Nigeria. Aldershot: Ashgate Publishing Limited.

Nyong' o, P A (ed). 1992. 30 Years of Independence in Africa: The Lost Decades? Nairobi: Academy Science Publishers.

Olorunsola, V (ed). 1972. The Politics of Cultural Sub-Nationalism in Africa. New York: Anchor Books.

Ogot, B A \& W R Ochieng' (eds). 1995. Decolonization and Independence in Kenya. London: James Currey.

Osaghae, E. 1994. Ethnicity and its Management in Africa: The Democratic Link. Lagos: Malthouse Press Limited.

Posner, D. 2007. 'Regime Change and Ethnic Cleavages in Africa'. Comparative 
Political Studies 40(1302). Available online: cps.sagepub.com/cgi/content/ abstract $/ 40 / 11 / 1302$

Russell, A. 1999. Big Men, Little People: Encounters in Africa. London: Macmillan.

Sandbrook, R. 1985. The Politics of African Economic Stagnation. Cambridge: Cambridge University Press.

Smith, Z K. 2000. 'The Impact of political liberalisation and democratisation on ethnic conflict in Africa: an empirical test of common assumptions'. Journal of Modern African Studies 38(1).

Southall, R. 1998. 'Moi's Flawed Mandate: The Crisis Continues in Kenya'. Review of African Political Economy 25(75).

Standard, The. 2008. 'Raila won last year's election, says US poll', 10 July. Available online: eastandard.net/business / InsidePage.php?id=1143989897\&cid=159\&

Stone, J. 1983. 'Ethnicity Versus the State: The Dual Claims of State Coherence and Ethnic Self-Determination'. In D Rothchild \& V Olorunsola. State Versus Ethnic Claims: African Policy Dilemmas. Boulder: Westview Press.

Sunday Standard 42007.

Swainson, N. 1977 'The Rise of a National Bourgeoisie in Kenya'. Review in African Political Economy 8.

Throup, D \& C Hornsby. 1998. Multiparty Politics in Kenya: The Kenyatta and Moi States and the Triumph of the System in the 1992 Election. Oxford: James Currey.

Van de Walle, N. 1994. 'Neopatrimonialsim and Democracy in Africa with an Illustration from Cameroon'. In J Widner (ed). Economic Change and Political Liberalism in Sub-Saharan Africa. Baltimore: The Johns Hopkins University Press.

Widner, J. 1994. 'Political Reforms in Anglophone and Francophone African Countries'. In J Widner (ed). Economic Change and Political Liberalism in Sub-Saharan Africa. Baltimore: The Johns Hopkins University Press.

Young, C. 1976. The Politics of Cultural Pluralism. London: The University of Wisconsin Press.

1994. 'Ethnic Diversity and Public Policy'. Draft occasional paper for the UN Research Institute for Social Development, World Summit on Social Development, Geneva, August. \& T Turner. 1985. The Rise and Decline of the Zairian State. London: The University of Wisconsin Press.

\section{Interviews}

Professor C J Odhiambo, Johannesburg, 18 October 2008.

Dulo Nyaoro, Johannesburg, 30 October 2008. 


\title{
THE 2007 GENERAL ELECTIONS IN KENYA Electoral Laws and Process
}

\author{
Felix Odhiambo Owuor \\ Felix Odhiambo Owuor is Senior Programme Manager of the \\ National Democratic Institute for International Affairs, Political \\ Parties Programme in Nairobi \\ e-mail: FOdhiambo@ndi.org
}

\begin{abstract}
The violence that followed the 2007 elections in Kenya sent shock waves through the country and around the world and raised questions about the Kenyan democratic landscape and the perception of stability in a region which is prone to violent conflict. Having come to power on the platform of comprehensive constitutional, legal and administrative reforms the National Rainbow Coalition government, headed by Kibaki, repeatedly reneged on promises to institute the reforms necessary to secure a new democratic dispensation and redress past imbalances. The consequence was a closely contested election, ethnic division, a flawed electoral process, a weak institutional framework and post-election violence that resulted in death, displacement and the destruction of million of dollars worth of property. This paper analyses the political and electoral environment in which the elections were held and attempts to explore the legal and constitutional framework governing elections in Kenya as well as to make recommendations for the democratisation of the electoral process.
\end{abstract}

\section{INTRODUCTION}

The consequences of Kenya's fourth multiparty elections, held on 27 December $2007,{ }^{1}$ are proof that although regular elections may be a critical element of a democracy they are not, in themselves, a guarantee of sustainable democracy. Despite the fact that the country had held elections faithfully and religiously since the attainment of independence in 1963, the 2007 elections and their immediate aftermath led to questions about the viability of institutional mechanisms in

1 Previous multiparty elections were held in 1992, 1997, and 2002. 
Kenya as safeguards of free and fair elections. Cumulatively, the problems which emerged pointed to the failure, over the years, to address the legal and structural weaknesses in the election system. At the centre of these failures were two separate but interrelated weaknesses: the constitutional, legal and administrative framework governing elections and the inability of the Electoral Commission of Kenya (ECK) to facilitate a free and fair election.

All these factors have renewed, with vigour, the debate that has persisted in Kenya since 1992 about the need for a comprehensive review of the country's Constitution and for pertinent reforms that reflect the new multiparty dispensation. In the short term, however, and because of the failures of the ECK, the Post Election Negotiation Committee, headed by former United Nations Secretary General Kofi Annan, recommended the establishment of various commissions to consider aspects of Kenya's political, social and economic system.

Of particular importance was the establishment of the International Review Commission (IREC) headed by Johann Kriegler, retired South African Constitutional Court judge and the chair of South Africa's first Independent Electoral Commission. The Kriegler Commission comprised seven members, four of them representing the Orange Democratic Movement (ODM) and the Party of National Unity (PNU). Their brief was to investigate all aspects of the 2007 elections and prescribe reforms that would guarantee transparency, sustainability and fairness in subsequent elections. Another important commission established after the 2007 election was the Waki Commission on post-election violence.

\section{POST-ELECTION PROBLEMS IN KENYA IN PERSPECTIVE}

To begin to understand the institutional failures in Kenya the proper starting point is to recap the events leading up to the 2007 elections. It is now widely accepted that the Kenyan state was built on quicksand, and the 2007 elections were merely the mechanism of destruction of a nation whose foundation was shaky. As various commentators, among them the Kriegler team, have noted, a number of factors contributed to the disastrous elections, the central one being the now defunct ECK.

\section{Tracing the problem: polling day activities}

- In general the proceedings on election day went well. Kenyans turned out in large numbers to vote, electoral materials were supplied well in advance to most polling stations and the conduct of the ECK personnel during the voting period was exemplary. 
- Essentially, the problems began on 28 December, when results began to trickle in from the various constituencies. By that evening the preliminary results released by the ECK revealed a 1-million vote gap between the ODM-Kenya candidate, Raila Odinga, and the PNU candidate, sitting President Mwai Kibaki.

- Then things began to go wrong.

- Returning officers covering areas regarded as Kibaki strongholds disappeared, causing delays in the transmission of results from Central and Eastern provinces.

- When the results from Central and Eastern provinces were finally released there were clear disparities between the provisional results released at the polling stations and the official results contained in the statutory forms at the ECK national tallying centres.

- Other anomalies included the submission of photocopied results contrary to the legal requirements, the absence of the signatures of presiding officers and party agents and of the ECK stamp that was crucial to authenticating the documents, and the correction of results that revealed discrepancies, for example, in areas that reflected a turnout of more than $100 \%$.

- As a consequence the final results released by the ECK on 30 December in response to pressure from both the PNU and the ODM-K revealed that President Kibaki had won with 4,5-million votes against Raila's 4,3 million.

- Within an hour after the ECK's announcement President Kibaki was sworn in at State House, Nairobi, for a second five-year term. Within minutes fighting and mass protests broke out in different parts of the country, with the majority denouncing the results.

\section{The Independent Review (Kriegler) Commission Report}

The report of the Kriegler Commission, set up to examine the integrity of the entire electoral process, including voter registration, voting, the counting process and dispute resolution, was explicit and categorical about the failure of the ECK to supervise the elections professionally and competently.

In fact, the problem began far earlier, when President Kibaki unilaterally appointed the 22 commissioners to serve on the ECK and, in so doing, eroded the perception of neutrality the commission had cultivated since 2002 and flouted the terms of the 1997 Inter Party Parliamentary Group Agreement (IPPG), which required the parties to nominate the commissioners. Regrettably, 
because the agreement was not entrenched in law Kibaki was able to replace existing commissioners with people who, by and large, had no previous electoral experience and who, for the most part, did not comply with the requirements of neutrality and professionalism.

Despite this, because the conduct of the ECK during and after the 2002 general elections and the 2005 referendum had been exemplary and above board both Kenya and the rest of the world believed the commission would be up to the task of ensuring a free and fair election in circumstances where competition would be fierce. This was not to be.

The National Assembly and Presidential Elections Act (Cap 7 of the Laws of Kenya) gives enormous powers to the returning officer with respect to elections at the constituency level. Apart from supervising such elections the returning officer has the power and discretion to extend voting hours and to order a recount before the results are announced.

With respect to the results, the returning officers and party agents must complete a series of statutory forms. With regard to the presidential election the 22 commissioners are jointly regarded as the returning officer for the purposes of tallying the votes and announcing the results. Evidently, and by the admission of the ECK, serious anomalies occurred during the tallying process at the constituency level and these, according to the Kriegler Commission's report, fundamentally affected the result of the presidential election.

While the poor tallying of results affected most constituencies the problem was particularly predominant in Central Province. In Juja constituency, Central Province, for example, provisional results indicated that the total number of votes for Kibaki was 48 293, however, at the ECK tallying centre the result for Juja was amended to 100390 votes, the figure the ECK relied on. This situation was repeated in most constituencies in central Kenya. In Maragua the number of votes cast was greater than the total number of registered voters, which forced the ECK to reject the result.

One of the decisions the commission had to make was whether the returning officers had made false declarations that were criminally actionable?

The Kriegler Commission declared categorically that the incompetence and ineptitude of the ECK was largely to blame for the election fiasco. While there was no evidence of misconduct at the national tallying centre, the process at the constituency level was so irredeemably flawed that it was almost impossible to judge who had won the election.

Accordingly, the commission recommended that the ECK be disbanded and replaced with a leaner, more efficient body. Appointments should be vetted by an independent body, preferably Parliament. 


\section{THE LEGAL FRAMEWORK GOVERNING ELECTIONS IN KENYA}

The present legal regime governing elections dates back to 1991 when, in response to local and international pressure, the Constitution was amended to reintroduce multiparty democracy. Section 2A of the Constitution, enacted by the Kanu regime in 1982 and outlawing the formation of other political parties, effectively making Kenya a one-party state, was repealed. The effect of the constitutional amendments enacted during the Kenyatta and Moi regimes was to centralise power in the executive, to entrench a monolithic system of government, and to curtail fundamental rights and freedoms, including the freedom of association and assembly (Kadima \& Owuor 2006).

The repeal of s2A and the subsequent reintroduction of multiparty politics, although hailed as a major political landmark, were, regrettably, not accompanied by constitutional, legal or administrative reforms. Consequently, the country embraced multipartyism without the reforms required for a true multiparty democracy.

The successes of the 2002 elections and the 2005 referendum further created a belief that the electoral system was perfect. In fact, it was legally and institutionally weak, faults that were glaringly exposed by the hotly contested elections of 2007.

\section{Kenya's obligations in terms of international and regional standards}

The significance of elections as a critical element in a democracy is recognised and enshrined in various international instruments, to which Kenya is a signatory. Prominent among these is the Universal Declaration of Human Rights, which explicitly provides, in Article 21, that 'everyone has a right to take part in the government of his country, directly or through freely chosen representatives'. The importance of elections is further affirmed in subs 3 of the declaration, which provides that 'the will of the people shall be the basis of authority of government: this will shall be expressed in periodic and genuine elections which shall be by universal suffrage and shall be held by secret vote or by equivalent free voting procedure'.

Among the international instruments that underscore the principles of citizen participation in democratic governance are: the International Covenant on Civil and Political Rights, the International Convention on the Elimination of All Forms of Racial Discrimination, the Convention on the Elimination of All Forms of Discrimination Against Women and the Convention on the Rights of Persons with Disabilities. There is also a host of regional instruments whose 
objectives, like those of the international instruments, is to promote and recognise the participation of citizens in governance processes. These regional instruments include the African Charter on Human and People's Rights, the Declaration on the Principles Governing Democratic Elections in Africa, and the African Charter on Democracy, Elections and Governance.

While Kenya is a signatory to these important instruments it lags behind in matters of enforcement and implementation. The problem lies in the fact that in the Kenyan legal system treaties negotiated and signed by the executive do not become part of the country's laws until they have been adopted by Parliament. The challenges of the 2007 elections and the problems associated with it now demand that Kenya move expeditiously to join the community of nations by ratifying and adopting these instruments. Besides, a widely acceptable norm with regard to the enforcement of obligations arising from international instruments is that states cannot circumvent their obligations and commitments arising from international agreements by failing to enact enabling legislations.

\section{ELECTORAL LAWS IN PERSPECTIVE}

The legal framework governing elections in Kenya can be divided into two parts. The first consists of laws enacted solely to govern elections. These include the Constitution of Kenya, The National Assembly and Presidential Elections Act, the Local Government Act, and the Election Offences Act.

The second set of laws, are those that, although they were not enacted expressly to deal with elections, nevertheless have a collateral impact on them and directly affect the process. They are: the Kenya Broadcasting Corporation Act, the Penal Code, and the Registration of Persons Act, among others.

\section{Post-election procedures}

\section{Internal evaluation}

In the immediate post-election period the ECK embarks on the routine work of retrieving material, storing it, paying staff, and assessing the election process. Since 2002 it has also conducted a two-phase post-election evaluation. The first phase is internal and consists of collecting information from the field and engaging the regional officers. The second includes stakeholders and provides an opportunity to discuss possible changes in the process. 


\section{Dispute resolution}

Section 44 of the Constitution gives the High Court jurisdiction to hear and rule on election petitions. This jurisdiction is extended by s 19 of the National Assembly and Presidential Elections Act (1998 Cap 7), which provides for the determination of whether the election of the president is valid. A petition to challenge the validity of the presidential election is heard by a bench consisting of three judges. A petition to challenge the validity of the election of a member of the National Assembly is heard by one judge. Rule 36 of the National Assembly Elections (Election Petition) Rules requires the attorney general or a person appointed by the attorney general to be present during all such cases.

\section{Procedure for election petitions}

Section 20 of the National Assembly and Presidential Elections Act requires that any election petition be presented and served within 28 days of the date of publication of the result of the election in the Gazette. A petition seeking a declaration that a seat in the National Assembly has not become vacant must be presented and served within 28 days of the date of publication of a notice declaring the seat vacant. However, a petition to seek a declaration that a seat in the National Assembly has become vacant may be presented at any time.

Finally, the law requires that within three days from the presentation of the petition the petitioner must provide security for any costs that may be incurred. Failure to comply with this deadline results in the dismissal of the petition. The Court of Appeal has held that failure to deposit security in time is not a mere irregularity to be waived by parties, in terms of s21(3) of the National Assembly and Presidential Elections Act, it leads to the dismissal of the petition. The courts have taken a rigid view of the technical rules, holding that there is no remedy for non-compliance. In addition, petitions may not be amended outside the stipulated period and parties' names must be strictly correct.

The procedural and technical ramifications of compliance required from parties wishing to lodge an election petition make the process cumbersome and it can take years for judgement to be handed down. To begin with, petitioners are expected to effect personal service on the respondents and many election petitions have been thrown out because of failure to comply with this requirement. Secondly, there is no court that deals specifically with election petitions matters - the chief justice must constitute a bench to determine electoral disputes.

The fact that the judiciary is currently coping with a serious backlog has further retarded decision-making in cases of electoral disputes. In 2003, for example, 34 election petitions were filed and most of the cases were only decided in $2006 / 2007$, while three have still to be heard. 


\section{REFORMING THE ELECTORAL PROCESS: POST-ELECTION INITIATIVES}

\section{Completion of the constitutional review process}

Agitation for a comprehensive review of the Constitution began in 1990 and today, almost two decades later, the country still does not have a new constitution. The four items singled out by the Panel of Eminent African Personalities as needing to be addressed as a matter of urgency to forestall future conflicts are all key constitutional issues that have been the subject of significant debate.

Towards the end of 2008 Parliament passed the Constitution of Kenya Review Act to pave the way for the completion of the constitutional review. The Act provide for the nomination by a parliamentary select committee (PSC) and appointment by the president of a committee of seven, three of them international experts. On 22 January 2009 the PSC selected three top African lawyers to serve on the review commission.

\section{Two new commissions}

'It lacks functional efficiency and is incapable of properly discharging its mandate' Kriegler Commission Report.

This was the finding of the Independent Review Commission on the ECK. The commission recommended that the body be dissolved and replaced with a new body, complete with a new outlook, name and ethos.

In a move towards implementation of this recommendation Parliament passed a constitutional amendment in November 2008 abolishing the ECK and replacing it with two interim commissions, the Interim Independent Commission and the Interim Boundary Commission. The two commissions will be constituted by Parliament and will divide between them the core functions of the former ECK, namely, electoral supervision and boundary delimitation. The two commissions will work for two years, at the end of which they will be dissolved to pave the way for more permanent commissions.

\section{The Waki report on post-election violence}

The commission to investigate the post-election violence was set up in 2008 in response to a recommendation by the Panel of Eminent African Personalities. It was headed by Justice Waki, who, in a detailed report, recommended that a local 
tribunal be set up to investigate 10 people suspected to be key to the instigation of violence. Failing that, the commission recommended that the suspects be tried in the International Criminal Court (ICC).

The report has posed problems for the government, with parliamentarians divided over whether a local tribunal should be set up, which would require a constitutional amendment providing for the entrenchment of such a tribunal, or whether the matter should be referred to the ICC. As a result a Bill relating to the establishment of a local tribunal and debated in Parliament on 5 February 2009 failed to win the mandatory two-thirds of the vote and will have to be tabled again.

\section{Other proposals for reform}

\section{Reform and consolidation of election laws}

As stated above the restoration of the multiparty system in 1992 was not accompanied by corresponding reforms and the country's laws continue to favour the incumbent party and president. Among the reforms that are needed are an electoral Act that codifies and consolidates all laws pertaining to elections and spells out clearly and concisely the procedural and substantive matters relating to elections.

\section{Electoral System}

Kenya's first-past-the-post single-member constituency electoral system has been the subject of debate for some time. The main criticism levelled against it is the high stakes associated with the winner-takes-all system, which, it is contended, are responsible for problems such as ethnicity, corruption, electoral fraud and violence.

Both the Bomas and Kilifi constitutional drafts contained a recommendation that a mixed member proportional representation (MMP) system be introduced, combining constituency-based elections with nominations based on proportional representation.

\section{Introduction of a two-chamber Parliament}

The introduction of a two-chamber Parliament (Senate and the House of Representative) would go a long way to dealing with the defects associated with the present electoral system and constituency boundaries. In the past the abolition of existing constituencies and changes to the electoral system have proved to be extremely emotive issues that have met with serious resistance.

The introduction of the Senate, as the upper house, with seats shared equally on a provincial/regional basis would compensate provinces affected by the 
creation of new constituencies. The fact that constituencies would be retained while representation issues would be addressed by the creation of the second chamber would allay the fears of those who are resistant to change. The creation of two chambers would, however, require a constitutional review or amendment.

\section{Compliance with the Political Parties Act}

The Political Parties Act is arguably the single most important piece of legislation introduced since the restoration of multiparty politics. It introduces reforms of the running and management of political parties which will have the effect of institutionalising their operation. To facilitate successful implementation of the Act strict enforcement and compliance mechanism should be put in place to ensure that political parties abide by its salient provisions. Parties must also develop clear rules for nomination procedures and deposit these with the ECK, whose functions should be extended to include supervising party elections.

\section{Post-election dispute resolution}

Two reforms should be put in place with regard to post-election dispute resolution.

- Enhancing the independence of the judiciary

After the disputed 2000 presidential election in the United States the then-vice-president, Al Gore, while disagreeing with the verdict of the Supreme Court, stated that he accepted it because of the faith he had in the American system. Faced with a similar situation after the 2007 elections in Kenya the ODM refused to seek redress by petitioning the courts, citing a lack of faith in the independence of the judiciary. Measures should be put in place to enhance the image of the judiciary as a neutral and impartial arbiter in all matters, including those related to elections. To avoid lengthy delays in the settlement of election disputes an electoral complaints tribunal should be set up to deal exclusively with such disputes.

- Prosecutorial powers of the ECK

The powers of the ECK should be enhanced to include a prosecutorial role in all election-related matters, as is the case in India. Increasing the powers of the ECK will ensure its effectiveness, particularly with regard to issues related to the enforcement of the Electoral Code of Conduct. 


\section{Comprehensive constitutional review or targeted reforms}

Comprehensive constitutional review in Kenya and the enactment of a new constitution has been very elusive. Although the clamour began in 1991 and peaked during the 2005 referendum the country still does not have a new constitution. The Kriegler Commission report confirmed the long-held belief in the political domain that Kenya has a weak legal and structural framework coupled with inequality in resource allocation. To restore the country to the path to sustainable democracy urgent steps should be taken either to revive the constitutional review process or to consider targeted reforms of key institutions and sectors.

\section{- REFERENCES -}

Kadima, D (ed). 2006. The Politics of Party Coalition in Africa. Johannesburg: EISA.

\& Owuor, F. 2006. 'The National Rainbow Coalition: Achievements and Challenges of Building and Sustaining a Broad-Based Political Party Coalition in Kenya'. In D Kadima (ed). The Politics of Party Coalition in Africa. Johannesburg: EISA.

Kriegler, J. 2008. Independent Review Commission Report.

United Nations. 1948. Universal Declaration of Human Rights. Document a/810, p 75 .

Waki, P. 2008. Report of the Independent Review Commission http:/ / wikileaks.org/ wiki/kenya:_waki_commission_of_Inquiry_into_Post-Election_Violence_ final_report_15_Oct_2008

\section{Legislation}

Political Parties Act no 10 of 2007

Constitution of Kenya Act of 2001

National Assembly and Presidential Elections Act of 1998

Election Offences Act (Cap 66)

Local Government Act (Cap 265)

Kenya Broadcasting Corporation Act (Cap 221)

Penal Code (Cap 63)

Registration of Persons Act (Cap 107)

Constitution of Kenya Review Act of 2008. 


\title{
THE ROLE OF THE KENYAN MEDIA IN THE 2007 ELECTIONS
}

\author{
Fredrick Ogenga
}

\author{
Fredrick Ogenga, an independent media consultant \\ and analyst, is a doctoral student in media studies at the \\ University of the Witwatersrand \\ e-mail: braco_od@yahoo.com
}

\begin{abstract}
This paper argues that the media occupy a central role in the advancement of democracy and should be upheld as an institution that protect democracy. The paper cites the role the Kenyan media played in the election crisis, acknowledging its success but at the same time questioning its failure to protect various aspects of democracy such as the election process. This it does by mentioning the work of various Kenyan journalists who criticised the election process through the media. The paper uses the ideal concept of democratic thought as conceptualised by the German philosopher Jürgen Habermas to examine clinically democracy in Africa and propose an alternative system of human relations as presented by the Ghanaian thinker Stephen Appiah to indicate a move to a more egalitarian society that still recognises liberal ideals.
\end{abstract}

\section{INTRODUCTION}

This paper discusses the recent political crisis in Kenya and the position of the Kenyan media following the disputed 27 December 2007 election between two main rival political parties, the Orange Democratic Movement (ODM) and the Party of National Unity (PNU). The critical question is which voices were being heard from the media and why, and the way forward for African democracy.

In an attempt to address these issues a critical approach is taken to the various theories of the press. This is looked at in the context of theories of democracy, particularly Habermas's concept of 'rethinking the public sphere' and the alternative ideas about the public sphere championed by Appiah, with a special look at his work on cosmopolitanism 


\section{THE PUBLIC SPHERE}

According to Habermas ${ }^{1}$ the public sphere is a political space created only during the electioneering period when the ruling class positions itself to convince the electorate (proletariats and bourgeoisies) through campaigns that they are fit to be their leaders.

Lucy Oriang', editor of the Daily Nation, the largest urban newspaper in Kenya, in an article dated 1 February 2008, wrote:

Only a month or so ago, this country [Kenya] was awash with posters, huge spending on billboards and a massive assault on our senses in both print and electronic media. The political parties spent billions trying to win us over to their side. We were inspired, and the turnout was more than even the most optimistic of pundits could have anticipated.

Two issues raised by this excerpt are the cultural role of the media in Kenyan society and the funding that gives politicians the power to purchase cultural capital, enabling them to contest for and win the lion's share of public space through the media.

Clearly, campaigning and advertising are costly pursuits. In the United States, for instance, according to Fox News, US President Barack Obama had raised campaign funds of \$52-million by June and his opponent, John McCain, \$21.5-million. Habermas argues that material resources give individuals the power to contest the public sphere and that, essentially, this space is dominated by the elite, who position themselves strategically and protect themselves from any form of opposition by discouraging plurality of thought.

From a classical Marxist perspective, then, this amounts to authoritarian tendencies by the ruling class, but from a post-Marxist perspective, it is a case of those who own that material resources having cultural capital and the means to buy their way into the public sphere and therefore win the consent of the majority.

In such an arrangement there is a power struggle between the elite and the bourgeoisie. Here, democracy is characterised by the possibility of encouraging some form of plurality of thought and the ability of citizens to exercise their freedom through an election process whereby they decide on the kind of leaders they want.

1 For more readings on the public sphere see Fraser 1992. 
Habermas points out that, although this process might seem liberal, it is still characterised by exclusions and limitations in that voters are left with limited options to choose from in the public sphere, given that, since most people languish in poverty, only those with material resources make it to this political space. Nevertheless, the power struggle between the bourgeoisie and the ruling class is heightened during the electioneering period, with elections forming the climax of democratic thought.

\section{BUT WHAT HAPPENS AFTER ELECTIONS?}

The president of the United States is more likely than the president of Kenya to deliver on promises made during an election campaign. However, the US president, too, inherits institutionalised state machinery (the industrial military complex built over the years by the strong foundations that define America's existence and socio-economic strategic positioning in world politics and which are unlikely to change.

In the circumstances, Obama's 'change campaign' will amount to little more than a change in the person occupying the White House and a different style of handling certain aspects of US foreign, health, education, and energy policies.

In his paper 'Rethinking the Public Sphere' (see Fraser 1992) Habermas defines the public sphere as a political arena created only during the electioneering period to create a public space to contest for power. He sees it as a very seasonal, semi-permanent, almost artificial arrangement where the so-called ruling class emerge to make promises to the bourgeoisie if elected.

\section{WHO MAKES IT TO THE 'PUBLIC SPHERE'?}

Habermas notes that wealth is a major determinant of who will achieve political success. In Third World countries as in Western countries it is mostly the rich who will succeed and voters have limited options come elections because they have only a limited group of people to choose from In Kenya, for example, the choice was between Mwai Kibaki, Raila Odinga, Kalonzo Musyoka and Uhuru Kenyatta. In order to achieve power, those who aspire to it make a multitude of promises.

Oriang' notes the following examples of promises given by Kenyan politicians during the elections by hypothetically identifying problematic issues of development and how the so-called leaders would quickly resolve them in order to garner support.

- Bad politics will inevitably breed bloodshed. Throw money into the mix, and there'll be hell to pay. So, there's tension in the teaching 
ranks and the election is just around the corner? Give them a juicy pay raise, but let it be known that it is only effective after the election That way you get to keep them on a leash.

- So the community next door is feeling that 'one of their own' is not in a high level government position? Well, give a slew of them the shadowy title of assistant minister. That will take care of the shared national resources issue, never mind that they don't really do any serious work and that they will not be sharing their pay with their constituents. Hell, no!

- As for free education, an election is hardly the right time to refer to the small print to do with class sizes and all the extra costs that come with children going to school.

- Are the long suffering people up in the north complaining about 'development' not reaching them? A handful of boreholes should do the trick. Better still, transfer some bulldozers to the district headquarters - and keep them there until after things have gone quiet. That way, they will not be asking how life is down there in Kenya.

I am sure you can find your own local examples of how cash campaigns have corrupted our politics. I will add one that is not on Oriang"s list. This one came from President Kibaki when he was still campaigning. I saw him saying it on television that there was no need for him to introduce money bearing his portrait and emphasising that he would never do so. Only weeks after the election Kibaki introduced a Sh 40 coin the economy did not need and justified it by claiming that it was a souvenir. That's when I realised that nothing has changed. I was not the only Kenyan who thought so, here is an excerpt from two Kenyan bloggers who share my view:

... When he came into power he said he will not change the currency and yet he's already done it. Kenyan presidents are all the same.

On the flip side of the coin, it has the inscription 'commemorating the 40th Anniversary of Independence'. There was a similar commemorative coin to mark the 10th anniversary of independence. That was a 10-sided 10 shilling coin. It was acceptable for payment, in the same way this one is, and was a one-off issuance. I expect that CBK will not be issuing more 40 / - coins after marking the end of these celebrations ... OO remind them of the shilingi Kumi coin. www.mashada.com 


\section{WHAT NEXT THEN FOR THE ELECTORATE?}

According to Habermas the bourgeoisie creates its own space, which he calls 'the subaltern counter publics', an attempt to resist domination by the ruling class and to topple it if need be through the formation of civil rights groups which spearhead civil disobedience, demonstrations, and strikes and sometimes create lawlessness.

In the absence of a strong civil society and workers' unions in Kenya the public took the law into its own hands, arranging demonstrations and protests. In the absence of security and order violence and crime was an obvious option.

According to Habermas, this type of action is a step towards democracy and should be permitted, but only if the demonstrations are peaceful and don't violate the human rights of any section of the population.

Among the reasons for the violent protests in Kenya was that tensions were brewing among members of different tribes, which can be related to a history of poverty and inequality. Habermas argues that in an ideal democracy there should be a multiplicity of opinions, and that different voices should be given a chance and be accommodated in an attempt to reach a common good. In addition he advocates greater equality among the citizens, though he accepts that real equality is difficult to achieve.

If we apply this to what happened in Kenya, it becomes clear that the country was moving against the grain of an ideal democracy. The government had no time for a multiplicity of opinions and made the right to demonstrate and protest illegal, thereby killing the subaltern counter public (oppositional groups such as civil and human rights groups, which are crucial in ideal democracy). The gap between rich and poor has grown under Kibaki's rule and the press has been muzzled and fundamental freedom of expression threatened by internet blogs.

\section{THE ROLE OF THE KENYAN MEDIA?}

It is well known that the media set agendas (McCombs, Shaw \& Weaver 1997; Graber 2000) and use values such as prominence (journalists quoting renowned public figures when reporting news stories) to satisfy the interests of the public. How, then, did the Kenyan media report on the crisis?

Prior to the elections the media did a tremendous job covering campaigns and providing air time and space for candidates to reach the masses. They also did well in releasing opinion polls that proved largely correct in predicting the outcome of parliamentary elections. One reason for the contested presidential election is that the media carried extensive coverage of the voting process and released unofficial results in which Kenyans believed. 
The problems arose when the official results did not match what the media had predicted. Soon after being sworn in the government banned all live broadcasting, a move that undermined freedom of the press and the very fundamental freedom of expression.

During this period of the media blackout a member of Kenya's Human Rights Watch, Maina Kiai, was quoted in an article published in The Star on 7 January 2008 and titled 'Kenyan media spurns violence and calls for peace', as saying that the Kenyan media had failed to search beneath the surface for the root causes of the political crisis.

He accused the media of suppressing the reality of what many saw as tribal cleansing related to the disputed presidential election. He continued, 'The only way to peace is through truth and justice. It's not enough to be calm; we need the truth.'

The situation raises two issues:

- One of the roles of the media is to inform, but within the boundaries of social responsibility. While they strive to report the truth by providing facts and objective accounts of events they must do so in a way that will not incite people to commit more violence.

- Tribalism is an identity problem which is aggravated by the stereotypes attached to the 'Other', whether these are negative or positive. Identity issues are ideological and one of the ways in which ideology ${ }^{2}$ thrives is through propaganda and the naming or blaming of the 'Other'. The worst cases become violent and have in them elements of tribal cleansing and genocide. The Senegalese president, addressing this year's AU summit in Ethiopia, equated the Kenyan situation with some form of genocide.

The Kenyan media abandoned the notion of commercialising ${ }^{3}$ news content for the sake of profits, avoided naming either the victims or the perpetrators of the violence, employed investigative/ critical journalism and chose to preach peace. This was a positive move, which was later to help reunify Kenya. This conduct demonstrates the maturity of the media and further proves that the Kenyan media uphold and respect their role in Kenyan society.

In any human rights issue related to two or more conflicting interest groups the rule of law anywhere in the world will defend the idea of balancing rights to see which rights outweigh others and which infringe on others. In this case,

$2 \quad$ For more on ideology see Althusser 1971.

3 For more on the economic factors that influence journalistic content see McNair 1998. 
the Kenyan media seem to have understood that the right to peace outweighed the right of Kenyans to know (freedom to receive information) which tribe was killing which and in what manner; information that would only have aggravated the situation.

However, according to Sisule F Msungu, writing from Geneva on 24 January 2008 in an unspecified publication, there are ways in which the Kenyan media failed Kenyans. Kenyans have always known the weaknesses of the Electoral Commission of Kenya (ECK) and the courts, which is why he found it necessary to examine the conduct of the media to determine what went wrong.

Msungu argues that in successive polls Kenyans have consistently ranked the media as the most trusted institution; ahead even of the church. Public institutions such as the courts and Parliament have never won the confidence of the country. He continues that while there has been intense discussion about how the international media reported the post-election violence there has been little discussion about how the local media handled the situation. The media could, and should have provided credible and useful information about the issues and numbers in the disputed constituencies.

Msungu notes that the media also failed to appreciate the importance of the dispute, and reduced it to a two-man affair, which he describes as the 'it depends on Kibaki and Raila approach'. He questions why the Kenyan media failed to play the role of watchdog by using the publicly announced results at polling and constituency level to ensure that there was no fiddling or allegation of fiddling.

Hours before the ECK declared Kibaki the winner, it was clear that the mainstream media - with their extensive network - had possession of most, if not all, the publicly announced results and could therefore independently come up with the tally.

He ends the article by claiming that both the Daily Nation, on its website, and the Kenya Television Network (KTN) did, in fact, display advance figures on 30 December, before suddenly withdrawing the figures. According to him, The Daily Nation's figures showed Odinga with more than 4,5-million votes and Kibaki with just over 4,2-million. ${ }^{4}$ Why, he asks, did they withdraw these figures?

\section{IS DEMOCRACY ALL ABOUT ELECTIONS?}

In view of the drama surrounding the Kenyan elections one might question the meaning of democracy. Democracy, ideally, simply means the freedom to elect the

4 See also Barkan 2008 and Barkan's update of his January / February 2004 essay 'Kenya after Moi'. 
leader of the majority's choice without fear of intimidation. In the United States democracy goes hand in hand with the first amendment to the Constitution, which concerns freedom of expression.

According to Habermas there is no such thing as democracy. However, he believes that any move towards an ideal democracy would have to encompass greater equality among citizens.

In an article entitled 'Kenya's crisis and challenges of democracy in Africa' (www.alainkanyinda.net 9 February 2008) Nyaga Munyi expressed the belief that Africa's democratic honeymoon is rapidly drawing to a close and Kenya's sudden drift into chaos is a wake-up call for a more concerted investment in governance programmes on the continent as a whole.

After a decade of democratic gains Africa now finds itself in a swamp, with Nigeria, Kenya, and even South Africa facing defining moments. The next five years will mark a watershed in the continent's democratic consolidation. Munyi claims that the violence in Kenya caused by political discontent brings into sharp focus the challenges of democracy in Africa and the need for heterodoxy in political governance among African governments and institutions working 'to promote democracy' on the continent.

The situation in Kenya, he continues, exposes the fragile nature of the country's democracy and points to the role the international community should play in developing African politics, which, like its music, moves in sweeping waves.

Democratic disillusionment has produced two major trends in African politics - the ethnic and the socialist appeals - which will complicate the continent's democratic development in the next decade. These trends, he concludes, reflect responses to a sense of economic exclusion, where ordinary people feel political institutions do not respond appropriately to their problems. This is best demonstrated by events in the three African 'pillar' countries - South Africa, Nigeria and Kenya. The recent elections in Kenya and Nigeria highlight an ethnic appeal.

In Kenya the government has a difficult task and a long and rugged road to travel.

- It must leave the media alone.

- It must ensure that Kibera, the biggest slum in Africa, and other slums in the country, are eradicated.

- It must allow the opposition to stage peaceful protests and include the opposition's agenda in the country's Constitution. 
Although the second of these tasks is unlikely to be completed any time soon, in relation to the last the government of national unity should ensure there are some radical shifts in the way the institutions that defend democracy - the legislature, the judiciary and the media - operate through constitutional amendments that are already taking shape.

\section{WHAT NEXT FOR KENYA AND DEMOCRACY IN AFRICA?}

In his work on cosmopolitanism Stephen Appiah (2007) writes about a situation in which people, driven by shared values, do not regard each other as strangers ('othering'). This ideal can be advanced by media interaction, especially through new media such as internet blogs and sites where people can interact in an effort to reach a common goal. No wonder Kenyans kept the world informed through internet blogs when a 'state of emergency' was declared and President Kibaki and his Mt Kenya henchmen banned all live broadcasts at the height of the postelection violence.

Africa appears to be the wrong context in which to practise the Western concept of democracy. Africa must distinguish between democracy as a means and democracy as a goal. There are four fundamental goals of democracy: to make rulers accountable and answerable for their actions and policies; to make citizens effective participants in choosing those rulers and in regulating their actions; to make the society as open and the economy as transparent as possible; and to make the social order fundamentally just and equitable (Mazrui 2002).

The first challenge is, therefore, how to achieve these goals in a manner that is appropriate to Africa (Obioma 2001). The second challenge to democracy in Africa concerns its relationship to development. One persistant question in this regard is 'is Africa underdeveloped because it is primarily undemocratic? Or is Africa undemocratic because it is primarily underdeveloped?'

There is a third dimension, which is often treated either as part of the package of development or as part of the package of democracy, when in fact it should be treated as a kind of independent variable. This dimension is stability - a socialpolitical precondition for both sustainable development and durable democracy. Africa's three greatest needs are development, democracy and stability - but not necessarily in that order. Alleviation of poverty is one of the fruits of democratised development and one of the gains when democracy and development are jointly stabilised and truly humanised (Mazrui 2002). Stability also means creating an enabling environment to produce wealth.

Professor Ali Mazrui (2002), questioning how Africa has fared in these areas of development, democratisation, stabilisation and the alleviation of poverty explores what the words mean. In relation to development he argues 
that economists naturally focus on issues like resource flows, levels of economic diversification, domestic mobilisation of savings and investment, national productivity and per capita income (see also Mookjerjee \& Ray 2001; Ghosh 2001; Hayami 2001).

Yet high levels of performance in those areas are achieved only after other elements of development have been measured. The most crucial may be partly cultural rather than purely economic. Development in promoting performance and mobilisation of domestic savings and investment capital may need to be preceded by development in areas such as the enhancement of managerial skills, transformation of gender relations, redefinition of the work ethic as a discipline of the education system, redefinition of the laws and rules about corruption to make them more culturally viable, and reform of Africa's schools and universities to make them more skills and culturally relevant. In a paper for the World Bank, former University of Liberia president Mary Sherman (1993) sets out the obstacles and some approaches to reforming higher education in Africa (see also Mungazi \& Walker 1997).

Mazrui further argues that structural adjustment has never been the primary economic problem in Africa - that has always been how to carry out cultural readjustment. Such a readjustment would not be a demotion of African culture, it would merely result in a better balance between the continuities of African culture and Africa's borrowing from Western culture.

Until now African has acquired Western tastes without Western skills; Western consumption patterns without Western production techniques; urbanisation without industrialisation; secularisation (erosion of religion) without scientification. Would Africa have been better off if it had retained its own tastes while borrowing Western skills - instead of absorbing Western tastes and retaining its own lower levels of skills? Would Africa have been better off with African consumption patterns and Western production techniques instead of the other way round?

Ultimately, the media in Kenya, and in Africa in general, have played an increasingly significant role in the advancement of the society by providing a platform for consensus on various contentious issues facing the continent. They have done this by educating and informing the public about various important issues. They also act as a cultural carrier of a society's way of life, ensuring that African culture is sustained in the face of a Western-dominated way of life. Most of the media operating in Africa have a local content policy which ensures that the abundance of Western concepts is ameliorated by a specified percentage of locally relevant information.

Unfortunately, the role played by the media in most countries in Africa has been undermined by political ambition and journalistic integrity has frequently 
been sacrificed on the altar of commercial interests and profits. However, many political regimes in Africa are becoming increasingly tolerant of criticism from the media and acknowledge the watchdog function of the media as a necessary step and a prerequisite for the media's existence in a so-called liberal democracy. This change in attitude is desperately needed if Kenya and other African countries are to move towards the ideal concept of democracy conceptualised by Habermas.

\section{- REFERENCES}

Althusser, L. 1971. 'Ideology and ideological state apparatuses'. In Lenin and Philosophy and Other Essays. London: New Left Books.

Appiah K A. 2007. Ethics in a world of strangers. London, New York: Penguin Books Limited.

Barkan, J D. 2004. 'Kenya After Moi'. Foreign Affairs online, 1 January 2004.

Fraser, N. 1992. 'Rethinking the Public Sphere: A Contribution to the Critique of Actually Existing Democracy'. In C Calhoun (ed). Habermas and the Public Sphere. Cambridge, MA: MIT Press.

Ghosh, B N. 2001. Contemporary Issues in Development Economics. London and New York: Routledge.

Graber, D A. 2000. Media Power in Politics. Washington, DC: CQ Press.

Gramsci, A. 1971. The Prison Notebooks. London: Lawrence and Wishart.

Hayami, Y. 2001. Development Economics: From the Poverty to the Wealth of Nations. Oxford and New York: Oxford University Press.

Mazrui, A. 2002. Who killed Democracy in Africa? Binghamton: Institute of Global and Cultural Studies.

McCombs, M, L Shaw \& D Weaver. 1997. Communication and Democracy: Exploring the Intellectual Frontier in Agenda Setting Theory. Mahwa, NJ: Lawrence Erbaum Associates.

McNair, B. 1998. The Sociology of Journalism. London: Arnold.

Mookjerjee, D \& D Ray (eds). 2001. Readings In The Theory Of Economic Development. Malden, MA: Blackwell Publishers.

Mungazi, D A \& L K Walker. 1997. Educational Reform and the Transformation of Southern Africa. Westport, CT: Praeger.

Obioma M (ed). 2001. Contending Issues in African Development: Advances, Challenges, and The Future. Westport, CT : Greenwood Press.

Sherman, M A B. 1993. Building Consensus for Higher Education Reform in Africa: Some Reflections. Washington, DC: World Bank, May. 


\title{
'WE'VE BEEN TO HELL AND BACK...' \\ Can a Botched Land Reform Programme Explain Kenya's Political Crisis? \\ (1963-2008)
}

\section{Samuel Kariuki}

\author{
Dr Samuel Kariuki is a senior lecturer in the Sociology Department, \\ School of Social Sciences of the University of the Witwatersrand \\ e-mail: Samuel.kariuki@wits.ac.za
}

\begin{abstract}
A central argument pursued in this paper seeks to accord primacy to the unresolved land reform programme in Kenya in debunking the genesis of the country's intermittent political crises since independence. It is argued that one cannot come to terms with Kenya's failed democratic process without acknowledging the extent to which patrimonial politics were systematically developed and sustained, and the key to this was land. Land as a resource of political patronage, to reward, and punish, those who were part of, or were perceived as outsiders in an evolving political system that personified the ideals of its leaders gained a particular premium, easily manipulated across the three presidential epochs: Kenyatta (1963-1978), Moi (1978-2002) and Kibaki (2002-2007). The failure of land reform contributed immeasurably to the conflict that followed the December 2007 elections. The spatial character of the electoral violence (eg, Rift Valley and Coastal Province) suggests systemic faults that have marked decades of historic injustices brought about by a land reform policy largely informed not by a constitutional pronouncement but by the interests of the incumbent president. The paper concludes that an end to Kenya's political crises is not fully contingent on resolving the land issue, but rather on transcending the quest for land reform as a contributor to economic growth and political stability. This outcome is achievable through more creative means of economic diversification. The reality of Kenya's demographic and environmental pressures attests to the
\end{abstract}

1 Opposition leader Raila Odinga, 17 April 2008, when he was sworn into office as the country's prime minister, a key step in a power-sharing deal aimed at ending Kenya's political crisis. Analysis of aspects of his speech available at: www.news24.com/News24v2/Components/Generic/News24v2_Print_ PopUp_Article 
urgency of a shift in the meaning and symbolism attributed to land within the country's polity and its economic realm.

\section{INTRODUCTION}

Kenya opened a new chapter in its political history when two wrangling factions, the Party of National Unity (PNU) and the Orange Democratic Movement (ODM), signed a power-sharing agreement on 28 February 2008 (The Daily Nation 29 February; The East African Standard 29 February 29 2008). The agreement brought to an end months of civil unrest and political bickering following the declaration of Mwai Kibaki (the PNU's presidential candidate) as the winner of the 2007 presidential election, held on 31 December 2007. Raila Odinga (ODM's presidential candidate) refused to concede defeat, alleging that he had won and that Kibaki had been illegitimately declared the president by the Electoral Commission of Kenya (ECK).

The declaration of Kibaki's victory sparked a wave of atrocities across the country, particularly in Odinga's political strongholds. These events caught the eye of the international community, which stepped in to facilitate the restoration of order in a country that was once the icon of peace on the continent.

The African Union appointed a team of international experts to mediate the crisis. The team comprised former United Nations (UN) Secretary General Kofi Annan and members of the African Panel of Eminent Persons - Graça Machel and former Tanzanian President Benjamin Mkapa. At the onset the mediators requested both the ODM and the PNU to appoint a group of people who would represent them at the negotiating table. ${ }^{2}$

The mediation process brought to the fore the fact that Kenya's current political challenges and the violence that marked the post-2007-election period were symptoms of deep-seated democratic deficiencies that remained unresolved in post-independence Kenya and included the failure to bring about wide-ranging constitutional, institutional and legislative reforms that would deepen democratic growth and reverse the ills of underdevelopment bequeathed by colonialism.

At the epicentre of Kenya's intermittent political crises since independence is the character of the post-colonial state, which, as argued by Lonsdale (2008), has traditionally been the sole agency through which Africans could aspire to the commanding heights of the economy in defiance of racially entrenched interests - in land, commerce and finance. Access to state power was central and was

2 The PNU was represented by Cabinet ministers Martha Karua, Sam Ongeri, Moses Wetang'ula and Mutula Kilonzo, while the ODM delegation was made up of MPs Musalia Mudavadi, William Ruto, Sally Kosgei and James Orengo. See Namunane Bernard, 'Annan pleads for grand coalition government' available at www.nationmedia.com. 
mediated through elections, which served as a mechanism for the redistribution of wealth accumulated from above (Tamarkin 1978, p 318).

The patron-client relationships that developed and characterised Kenya's patrimonial politics constituted an exchange of material benefits for political influence and loyalty (Tamarkin 1978, p 318), which ensured that state power was concentrated in an executive presidency, directly elected but able to manipulate public institutions and dispense political patronage on the basis of ethnic mobilisation. Hence the competition for a share in this power is mediated through internal ethnic accountability and tribal politics/ rivalry.

This situation was typified by the leadership of Kenya's first president, Jomo Kenyatta, in 1964, when patronage politics was played out within the realm of land reform. Kenyatta and the Kikuyu elite soothed the frustrated honour of the Kikuyu poor through settlement schemes in the former 'white highlands' (Rift Valley), in which the less favoured Kalenjin and Maasai groups had indigenous claims to land (Lonsdale 2008, p 3).

The attempt under Kenyatta to Africanise both the public and private sectors manifested as 'kikuyuisation', a practice which alienated other ethnic and racial groups (Southall, 1999, p 94). This continuity in a governance system that was highly ethnicised and exclusionary was perfected in 1978 by Kenyatta's successor, Daniel arap Moi, whose presidency, though marked by a declining economic base and opportunities for personal enrichment, galvanised political authoritarianism that was exclusionary and aimed at developing an ethnic elite from his Kalenjin tribe at the expense of those who were now tribal rivals in land, urban property, or petty trade.

This institutional configuration ensured that electoral politics became a highstakes game. The centre of power, the Office of the President, with its allocative and coercive powers, created a space in which the contest for political power was a hard-fought battle that took on an ethnic dimension which centred on ethnic rivalry and competition that sought to lay claim to state largesse, which increasingly came to be seen as the ultimate guarantor of wealth accumulation (Klopp 2001, p 476).

This mode of political practice marked Kenya's 45 years of post-independence (1963-2008). Commenting on the 1997 multiparty elections Ajulu (1998, pp 279-282) notes succinctly that one of the core features of Kenya's political system was its ability to invoke ethnicity in political mobilisation as a conduit for control of the state and to effect a governance system that was exclusionary and authoritarian. This calls into question the stability of Kenya's long-term political future, as Ajulu (1998, p 283) further warned: 'The Kenyan situation has not exploded yet, but developments certainly push in that direction, unless of course a workable power-sharing formula can be found.' 
Hence, with every successive election popular resentment has grown among Kenyan citizens, to the extent that the clamour for constitutional change became a defining political feature in the post-1990s epoch (Lonsdale 2008, p 3). Moi's departure from the presidency in 2002 after 24 years in power did not, however, bring about the much-anticipated democratic reforms. Under the presidency of Mwai Kibaki the new ruling coalition promised to focus its efforts on generating economic growth, combating corruption, and rewriting the country's Constitution. Despite a marked improvement in economic growth, constitutional reforms were not effected. Like the preceding regimes Kibaki's first term was beset by controversy.

The period between 2003 and 2007 was marked by extensive political animosity between pro-government and other political parties, which, to all intents and purposes, culminated in the election violence seen in December 2007 (Sjögren \& Karlsson 2008). This electoral crisis was an elaboration of a failed democratic transition which can largely be analysed through the prism of a botched land reform programme, whose latent function was to meet political objectives, as opposed to dealing with a history of unjust redistribution. The outcome of such a programme, I argue, was essentially to redistribute political patronage, which inevitably led to retribution by a supposedly 'privileged' tribe (the Kikuyu), whose historic claims to land (for example, in the Rift Valley) were not vested in their current occupation, but with the Kamatusa tribes (Kalenjins, Maasai, Turkana and Samburu).

These ethnic cleavages, which politicians intent on maintaining power sustain by intermittent ethnic mobilisation, form the basis of Kenya's sporadic election crises since the advent of multiparty politics in 1992. Against this background this paper examines Kenya's post-election crisis with a view to highlighting the underlying factors that might have instigated it, significantly, the land question, which has come to represent the exigencies of building a new political and democratic order that accommodates varying and often irreconcilable interests.

Within the Kenyan political discourse these interests took on an ethnic dimension that was interdependent with the political system. Recognition of this factor has often been underplayed in the analysis of Kenya's political system, in particular in relation to struggles for ownership and access to land as a basis for claims by elites to political power. Roger Southall (2005, p 142), in his analysis of the Ndung'u Report, avers that: '[...] whilst I recognised land-grabbing (especially by local councillors) as a phenomenon, I failed to appreciate how enormously extensive the illegal appropriation of public land was to the formation and consolidation of Kenya's political elite.'

The primacy of land allocation as a basis for building political alliances and loyalty cannot be overstated within Kenyan political discourse, and this will 
become evident in a review of the historical antecedents of the December 2007 elections.

This analysis will attempt to elucidate the centrality of land reform, and how this programme was politically managed and manipulated to consolidate political power. The presidential periods of Kenyatta (1963-1978), Moi (1978-2002) and Kibaki (2002-2007) will be reviewed briefly. A key characteristic of all these periods is the degree to which ethnic mobilisation for control of the independent state intensified the growth of authoritarianism (or what others have termed kleptocracy), whittled down the expansion of the democratic space as the clamour for political power was intricately fused with the use of the state as a site of accumulation, and the suppression of political dissent (Ajulu 1998, pp 279-282).

Kenya's embryonic post-independence phase was the foundation on which future political developments were built. The primacy of land in contributing to the quality of life, sustenance and coping strategies among Kenyans is evident when considered against the socio-economic and demographic facts that obtain in the country. This becomes more apparent when one considers the scarcity of arable land in Kenya, its burgeoning population, and the insistence of Kenya's political principals on using land ownership, access, and control as a basis for mobilising the country's resilient political patronage system.

\section{Socio-Economic and Demographic Features of Kenya}

\section{Extent}

Total: 582646 sq km (45-million hectares) of which 97,8\% is land and 2,2\% water surface. $20 \%$ is medium-to high-potential agricultural land, the rest is either arid or semi-arid.

\section{Population}

In 1963 - 10 million; in 2007 - 38 million.

$75 \%$ of the population lives within the medium- to high-potential areas, the rest in the vast arid and semi-arid lands (ASALs).

Population density in the ASALs is two persons/sq $\mathrm{km}$.

In parts of the Central, Western and Rift Valley provinces it is 2000 persons / sq km, $60 \%$ of them below the age of 18 and more than $51 \%$ female.

\section{Land and Economy}

$78 \%$ of the population lives in rural areas and $22 \%$ in urban areas.

Agriculture and pastoralism provide a living for $75 \%$ of the population, support

$70 \%$ of employment and are responsible for $80 \%$ of export earnings.

$50 \%$ of Kenya's livestock is found in the arid and semi-arid lands 
As seen in the box above the inability to diversify the economy creates further pressure for access to land and ownership as the single most important resource for the majority of Kenyans.

\section{KENYATTA'S PRESIDENCY AND THE LAND QUESTION, 1963-1978}

As in other countries in Africa the emergence of settler colonialism in Kenya in the late 1800s created dispossession and landlessness, particularly in the Kenyan highlands. This generated intense resistance, which culminated in the first African nationalist movement in 1944, the Kenya African Union (KAU), whose primary concern was land and social inequality. Resentment of white domination and discriminatory land policies led to the $\mathrm{Mau} \mathrm{Mau}^{3}$ guerrilla campaign from about 1952 (Bogonko 1980, p 70). Kenya was placed under a state of emergency from October 1952 to 1959.

KAU was banned in 1953 and Kenyatta and other leaders were imprisoned (Sorrenson 1967, p 64). In 1960 KAU was renamed the Kenya African National Union (Kanu) and was led by J S Gichuru, Oginga Odinga, Tom Mboya and, later, Jomo Kenyatta, on his release from prison in 1961 (Miller 1984). A combination of the Mau Mau campaign and the increasing inability of the colonial power to govern forced the latter to commence negotiations with African leaders with a view to ceding power. This led to the formulation of a negotiated framework of constitutional arrangements for Kenya's independence (Harbeson 1974, pp 231-51).

At the dawn of Kenya's independence on 12 December 1963 the country's politics was dominated by two parties, Kanu and the Kenya African Democratic Union (Kadu) (Sjögren \& Karlsson 2008). These parties were merely 'ethnic federations' dependent on the personalities of specific leaders and the loyalty of their members. Kanu, for example, which made the greatest claim to representing a Kenyan nation, had a largely Kikuyu and Luo leadership (Klopp 2001, p 476).

Kanu, essentially an alliance between politicians from the Central and Nyanza provinces, was a proponent of a centralised system of government. The party defined community as the nation to which all belonged and maintained that all had the right to land anywhere, subject to national laws and market exchange. The differences between Kanu and Kadu, which represented tribes such as the Kalenjin, were deep and were most irreconcilable in relation to the way land previously held by white settlers and the colonial government was

3 The Mau Mau was a land-freedom army whose origin is clouded in mystery. The guerrilla group was mainly composed of Kikuyu, who rose against the European colonial authority and against Kikuyu 'loyalists' and European settlers. However, their chief target was land problems that dated back 30 years. For more analysis, see Bogonko 1980, p 70. 
to be re-distributed (Ndegwa 1997, pp 599-616). Kadu was a conglomeration of a number of ethnic parties, some of which had made common cause with the white settlers as 'minority' groups. The fertile Rift Valley land appropriated by the settlers was a key issue of debate in the party.

Kadu was united by a desire to keep the primarily Kikuyu migrant labourers and 'squatters', the backbone of the Mau Mau revolt, from making claims to Rift Valley land (Klopp 2001, p 477). As a minority party, however, Kadu, which had been founded in 1960 to defend the interests of the smaller ethnic groups, dissolved itself voluntarily in 1964 and joined Kanu. Kenyatta skilfully used persuasion, particularly access to state resources, to bring Kadu MPs, including their leader, Daniel arap Moi, into Kanu. In exchange for a share in power Kadu dropped its opposition to settlement schemes in the Rift Valley which were meant, in part, to deal with landlessness and the political unrest associated with it (Klopp 2001, p 477).

The smaller ethnic groups in the Rift Valley and Coast provinces were concerned with the prospect of domination by the country's two largest ethnic groups, the Kikuyu people of Central Province and the Luo from Nyanza, who, between them, comprised nearly 40 per cent of the total population (Harbeson 1974). Because of its numerical strength Kanu had much to gain from centralised control over economic and political resources, a mode of political despotism exemplified in the response of Kenyatta's government to criticisms within his own party, chief among them over the question of land reform, which marked the embryonic phase of Kenya's political development in the early 1960s.

The political conflict within the party was partly based on the divergent approaches of politicians to the land question. This argument divided both moderate politicians (eg, Jomo Kenyatta and Tom Mboya) and radicals (eg, Bildad Kaggia, Oginga Odinga and J M Kariuki). Land policy became a significant bone of contention and no one tried more conscientiously than the militant nationalist Bildad Kaggia to put the government on the road to a policy that would be good for the expansion of the Kenyan economy, the interests of the landless and the confidence of the poor people who had elected the government. Kaggia, and other organisers of Kiama Kia Muingi (KKM), a movement mainly made up of landless peasants, insisted that Kenyans should not to be forced to buy back land that was rightly theirs (Cheche 1982).

Kaggia's stand on land led him into public confrontation with President Kenyatta, who, on successive occasions, made clear his view that the policy Kaggia advocated was inconsistent with the principles upheld by Kanu in relation to the freedom of the individual and the protection of individual rights. Nationalisation of property was not, therefore, possible. This key argument dominated land debates in the 1960s (Gertzel 1970, p 46) and met with sharp criticism from other 
militant nationalists, particularly Oginga Odinga. In May 1961 on the outskirts of Nairobi Odinga, a militant nationalist, addressed a crowd of nearly 20 000, which collectively vowed never to buy land in the highlands.

The growing militancy over these all-important issues was successfully undermined by an alliance of Kanu moderates and reformist British de-colonisers. At a rally in Mombasa in July 1964 Odinga suggested that the government should give undeveloped lands to the poor to farm. At another rally, in February 1965, Odinga announced that the government should introduce a limit to the amount of land any one person might buy (Ogot \& Ochieng 1995, p 96).

None of Odinga's statements necessarily conflicted with the broad outlines of government policy but they implied a more radical approach, particularly to land, than official policy acknowledged, and brought him increasingly into public conflict with his Cabinet colleagues (Gertzel 1970, pp 56-57).

As a result of these differences over land reform Odinga was stripped of the party's vice-presidency in 1966. He resigned from Kanu and the government on 14 April 1966 and was followed out of the party by 29 members of Parliament. Bildad Kaggia, Achieng Oneko, Joseph Nthula, Zephania Anyieni, Tom Okello Odongo and Oduya Oprong, led by Oginga Odinga, formed the Kenya People's Union (KPU), which was supported by urban workers, trade unions, students, former forest fighters, ex-detainees and a hard core of embittered landless people who supported socialist policies. In their war of words with Kanu over the next three years (1967-1969) the KPU insisted that Kanu's African socialism was simply a cloak for the practise of tribalism and capitalism (Gertzel 1970, pp 56-7). The KPU's constitution defined its objective as the fight for the economic independence of the people of Kenya.

The radicals of the KPU, who posed a potential political threat to the Kenyatta government, now launched their activity from Parliament, led by populist member J M Kariuki, with support from the university. J M, as he was popularly known, regarded himself as a man of the people and stood for justice and the equality of all Kenyan citizens. Both in Parliament and on public platforms Kariuki championed the people's rights to free medical services, education and land (Ogot \& Ochieng 1995, p 100). He was staunchly supported by peasants, students and nationalists such as J M Seroney, Martin Shikuku, and George Anyona.

Such arguments failed to move Kenyatta, who viewed his opponents as 'agents of communism' whose mission was to dethrone him. The socialist KPU platform simply confirmed his fears. In its trade of words with Kanu over the next three years (1967-1970) the KPU insisted that Kanu's African socialism was simply a cloak for the practice of tribalism and capitalism (Ogot \& Ochieng 1995, p 100).

The KPU claimed that under the Kanu government the status of the peasants, for the most part, remained unchanged and the workers could no longer believe 
the government was working on their behalf. In response Kenyatta banned the party in 1969 and threw its leaders into detention. In the same year Tom Mboya was gunned down in broad daylight in a Nairobi street.

In March 1975 Kariuki was found murdered in the Ngong Hills (Ogot \& Ochieng 1995, p 100) and, in the following 20 months, a number of other radical politicians and academics, including Flomena Chelagat, George Anyona, Martin Shikuku, Ngugi wa Thiong'o and J M Seroney, were imprisoned or detained on criminal charges (Ogot \& Ochieng 1995, p 100).

Hence, by the late 1970s few voices were raised against the ruling clique. Kenyatta continued to rule the country in an increasingly autocratic and unilateral manner, with growing restrictions on freedom of expression of dissenting views both from within Kanu and from outside it. The political realm was increasingly dominated by a small elite group, the so-called 'Kiambu Mafia', resulting in the emergence of a class of capitalists, mainly from Kenyatta's tribe, the Kikuyu (Adar $\&$ Munyae 2001). This class enjoyed growing prosperity and political influence and repressed any resistance against it, as indicated in the following section.

\section{LAND REFORM INITIATIVES}

Land reform in Kenya predates independence. The implementation of the Swynnerton Plan in the 1950s was a political ploy to pacify rural unrest by creating a landed gentry. The essence of the Swynnerton formula was the privatisation of land through the displacement of indigenous property systems, relations, and modes of production and their replacement with a new legal order modelled on the 1925 English Land Law.

The intention was to provide African farmers with sound agricultural development based upon a system of land tenure that made available to them land and a farming system which would support their families. Customary land tenure was viewed as anti-modern, conservative, and incapable of bolstering agricultural modernisation and growth (Ondiege 1996, p 125; Okoth-Ogendo 1998).

The Swynnerton Plan contained a strategy for the development of production in small farming areas in the highlands, which remains the basis of Kenyan agrarian policy today. It provided for what came to be known as 'land tenure reforms', involving the consolidation of fragments of land where fragmentation was severe and the subsequent registration of individual freehold title.

There were three distinct stages in the process of tenure reform. The first involved ascertaining individual or group rights under customary tenure approximating to ownership, that is, the process of adjudication. The second involved the aggregation of all pieces of land over which individuals or groups had rights and the allocation to the individual or group of a single consolidated 
piece approximately equal to the several units. This was called the consolidation process. The last stage involved the entry of rights in the record of existing rights or adjudication register into a state-maintained land register and the issuing of a certificate of ownership, that is, the process of registration (Mugabe \& Ogolla 1996, p 99). However, the overall thrust of the plan was politically motivated - it was a response to the growing political crisis associated with the Mau Mau revolt among the Kikuyu in the 1950s. Colonial policy-makers thought it would start a process that would create an African rural elite, rooted in land and committed to private enterprise, which would also provide liberal political leadership (MigotAdholla \& Bruce 1994, p 124). The programme was also a product of the debate about the efficacy and superior status gained from Western-style freehold property systems as opposed to the conservative indigenous and traditional anti-modern property systems found in African communities.

\section{OUTCOME OF THE SWYNNERTON PLAN}

The consequences of the implementation of the Swynnerton Plan were counterproductive. The adjudication procedures were open to abuse by those involved in defining the existing structure of rights. The very process of registration gave rise to conflict and to pre-emptive measures to establish claims to uncultivated land by those with knowledge of the registration procedures.

Registration of title was the focus of violent ethnic clashes during political conflict in Kenya as late as the 1990s. Moreover, registration of title confirmed the rights of male landowners, at the expense of the numerous other parties with claims to the use of the land and to its products. The registration programme weakened the rights of women and also, in certain areas, the rights of tenants to the use of trees and access to grazing land (Heyer 1981).

Kenya's land reform was focused on the promotion and increase of freehold property rights. Registration of land was intended to transform the legal status of affected land from being susceptible to multiple customary rights and interests to being dominated by absolute, individual ownership. The process also converted the land into a commodity which could be sold, leased, charged or mortgaged at the discretion of the proprietor.

Part of the rationale for the programme was that it would give peasant farmers access to credit facilities using the security of registered title (Mugabe \& Ogolla 1996, p101; Migot-Adholla \& Bruce 1994). However, most smallholder farmers were reluctant to use title deeds for mortgage. This is partly because borrowers were wary of risking the loss of their main economic asset and security. For people who lacked marketable skills and opportunities for other careers the loss of land by default would have had severe consequences. Most financial 
institutions did not attach much significance to titles. In place of land titles other forms of security were sometimes used. Those who had buildings or off-farm employment also qualified for formal credit (Migot-Adholla \& Oluoch-Kosura 1994, p 135).

The resilience of the customary land system was evidenced in the continued prevalence of land-use practices based on customary norms in areas where land had been registered. Communities have continued to use customary rules of access to multiple sites instead of relying on their registered parcels (Migot-Adholla \& Bruce 1994). This resilience was also reflected in the land transactions that were conducted outside of the formal framework of registration because the possession of title did not appear to benefit farmers through credit use and increase in yields. Land registers became outdated and most land transactions were conducted in accordance with indigenous practices rather than statutory law (Migot-Adholla \& Oluoch-Kosura 1994, p 139).

The statutory registration of title did not fully replace the 'customary' law. Rather, statutory and 'customary' strategies have been used in tandem to secure rights to land and control the disposal of land on inheritance. As land became scarce claims of lineage were asserted to keep or recover control.

The establishment of customary law led patrilineal groups to exclude women's claims to land and the registration of land rights failed to create a 'free market' for land (Sorrenson 1967). This explains why women accounted for less than five per cent of the total registered landholders. Those who profited were heads of households, who, in many communities, were adult males (Kibwana 1990). Registration programme weakened the rights of women and also, in different areas, the rights of tenants to the use of trees and access to grazing land (William \& Francis 1993).

The conversion of freehold tenure made it virtually impossible to bring to the register all the multiple rights claimable under customary law. Public grazing lands disappeared as people moved in to claim every bit of land under the rubric of cultivation. For pastoral communities individualisation of tenure was deemed to be inappropriate, since animals had to traverse large tracts of land still held corporately. The Land (Group Representatives) Act Cap 287 of 1968 introduced a category of general territorial rights, which, upon identification, were then vested in group representatives.

The 'group' was defined in such a way as to include anything from a 'tribe' to a nuclear family (Okoth-Ogendo 1998, p 11). This attempt to accommodate some features of customary land tenure generated community disputes across rural Kenya (Kibwana 1990, p 239). However, as Okoth-Ogendo (1994, p 11) has demonstrated, the administration of group registration areas accentuated problems of conflict and accountability during the implementation process. 
The widespread existence of absentee landlords was another important feature of tenure reform in Kenya. Large tracts of land remained uncultivated despite recurrent food shortages and landlessness in the country. Private property rights thus encouraged accumulation and speculation, thereby withdrawing land resources from productive use (Mugabe \& Ogolla 1996, p 103). The registration process also increased rural debt as farmers failed to pay back loans they had obtained using their privatised farms as collateral, problems caused by speculative trading in land, illegal subdivisions of registered land, and absentee landlordism (Caldwell 1999).

The emergence of a clandestine land market was a key feature of the process. Many people were not willing to consolidate their various parcels and thereby lost the benefits of risk distribution inherent in the structure of fragmentation and the location of parcels and adjudication personnel were often constrained in many areas to apply 'gentle pressure' to achieve this result. As a consequence a clandestine land market emerged, in which parcels that could not be physically exchanged were simply sold, usually to people within the adjudication area but sometimes to strangers and other immigrants. Land prices were extremely depressed, sometimes so low that within a year of being registered, a piece of land could be sold for more than 1000 per cent of its original purchase price (Okoth-Ogendo 1998, p 12).

Although Kenya enjoyed some of the highest productivity increases in Africa during the initial period of tenure conversion (mid-1950s to late-1970s), the relationship between individual tenure and increased agricultural output is questionable. Many believe that the removal of prohibitions on Africans producing high-value commodities (tea, coffee, and dairy products), coupled with substantial investment in communication and transport infrastructure in the 1950s and 1960s, improvements in extension services, and the establishment of credit institutions have been more important than changes in land tenure arrangements (MigotAdholla 1985).

In terms of purely economic indicators Gutto (1995, pp 38-39) argues that land tenure reform in Kenya was believed to have led to the overall increase in productivity among the African middle class and peasantry in the 1960s, 1970s and early 1980s - mainly as a result of the lifting of colonial restrictions on access to land, the growing of cash crops and access to agricultural inputs. For instance, Mugabe \& Ogolla (1996, pp 103-104) note that after registration there was a marked improvement in land use and environmental management in many areas.

Land registration was also responsible for the increased use of credit facilities, required for land improvement. Privatisation of land among smallholders changed farmers' perceptions of the value of land and encouraged them to invest in permanent improvements, to adopt new technologies from multiple 
sources, and to rehabilitate the environment, provided the government ensured an enabling macro-economic policy framework (Caldwell 1999). Ondiege (1996) similarly points out that agricultural production may have increased because of the transition, in some cases by force, from pastoralism to intensive agriculture. For instance, in Machakos district, a colonial destocking campaign pushed the Akamba into intensive agricultural production.

However, William \& Francis (1993, pp 390-391) argue that the great transformation of Kenyan agriculture was not brought about by changes in the legal status of the right to land. They maintain that at best it could be argued that registration of title has not prevented agricultural growth, perhaps in part because people have circumvented its rules.

The boom in smallholder farming was made possible by a combination of circumstances. International capital became increasingly important in the political economy of Kenya, and the influence of European settlers declined. This facilitated inflows of investment in transport, processing, and marketing and was associated with new patterns of class formation and emergent class alliances, which underpinned the land question at independence.

Buoyant external and internal markets encouraged the expansion of agricultural production and industrial investment. However, Okoth-Ogendo (1998) contends that whatever contribution land tenure reform may have made to economic growth the gains have been completely offset by the emergence of economic disparities, the redistribution of political power, and the disequilibration of socio-cultural institutions that have occurred in rural society as a consequence of reform.

Clearly there is little consensus among scholars about the impact of individualised land tenure on productivity, as noted in the example of Ghana. In Kenya, conclusions tend to vary depending on the period of analysis. In the 1980s and 1990s production levels failed to match the increase in population, due, in part, to land tenure problems such as continuous uneconomic land subdivisions and poor agricultural and land-use policies (Ondiege 1996, p 126). Gutto (1995), on the other hand, contends that the decline in agricultural production experienced in the late 1980s and 1990s was partly due to political instability, lack of redistributive strategies, and the related phenomenon of official corruption.

Overall, the reforms created more problems than they resolved, generated more disputes over land ownership, and resulted in a more skewed distribution of land. They also produced and reinforced ethnic-based interests in land, and made the land question more complex than ever. The post-independence government simply retained the colonial land laws and pursued the same land reform objectives. The land policy did not change in spite of the complex issues that developed around it, and despite the fact that the government, after 
independence, identified landlessness as a major constraint to the national goal of self-sufficiency in food.

The debate over the efficacy of individual titling was driven more by 'economic reductionism', which tended to link individual tenure as a key prerequisite to agricultural modernisation (Kanyinga 2000). This approach ignores the wider social and political context that shapes access to land and the inherent power relations that define property relations within communal land systems. Although the programme is by no means complete it is estimated that more than 70 per cent of all land outside the arid areas of the Coast, Eastern, North-eastern, and Rift Valley provinces has now been privatised (Okoth-Ogendo 1998).

Writing in 1976 Okoth-Ogendo ( $\mathrm{p} 1$ ) noted that the registration process will only near completion by the year 2050 - a full 100 years since the process began. The land reform programmes implemented in the post-independence era (1963) similarly articulated a political rationale aimed at establishing political stability and not necessarily at comprehensively restructuring the skewed land ownership patterns. A brief overview of the Million Acre Settlement Scheme attests to this argument.

\section{THE MILLION ACRE SETTLEMENT SCHEME}

In the 1960s, as Kenya was attaining its independence from Britain, a massive programme of land transfer was undertaken to convey some 1,2-million acres of formerly European-owned, large-scale farms and ranches into the hands of African smallholders. The programme, called the Million Acre Settlement Scheme, involved some 35000 African families. The scheme helped to meet the economic demands of colonial Kenya's white settler community, the political objectives of the nationalist leadership, the land grievances of Kenya's poor, and the aspirations of the upwardly mobile and emerging middle class. In the process of achieving all these objectives it helped to make the terms of Kenya's independence economically and politically acceptable to the various factions (Leo 1981, pp 201-2).

In 1961 the colonial government started dual settlement schemes, the Yeoman and Peasant schemes, administered through the Land Development and Settlement Board (LDSB), which the government had appointed at the beginning of that year to administer the settlement of almost 8000 families. In order to satisfy the demand of Africans for redistribution of land some farms would be subdivided into smaller holdings.

One scheme was to consist of yeoman farms of about 20 hectares, integrated into the large farm sector. On the other hand peasant schemes with farms of about six hectares were established on land contiguous with the African reserves. The aim of the dual structure, according to the LDSB, was to maintain agricultural 
output and stability in the rural areas (Leo 1984, p 73). By mid-1961 it was clear that the schemes were a total failure and should be replaced with a more comprehensive settlement scheme, namely the million acre scheme. The Yeoman and Peasant scheme had tried to achieve reconciliation between Europeans and Africans by means of a plan which ignored the problem of landlessness (Leo 1981, p 222).

The million acre scheme was as delicate and multifaceted a political bargain as those accomplished strategists, the British colonial authorities, ever negotiated. It helped to meet the economic demands of colonial Kenya's white settler community, the political objectives of the nationalist leadership, the land grievances of the poor, and the aspirations of the upwardly mobile and the emerging middle class (Leo 1981, p 201). In essence the programme was geared towards appeasing the growing disenchantment of landless people.

Eligibility for the new programme was based not on what prospective settlers possessed but on what they lacked: land and employment. The deposit required for most of the so-called high-density schemes was nominal, and there were no requirements as to training and background (Leo 1984, pp 53-5). This explains why, at the completion of the million acre scheme, only 3800 families had been accommodated, less than one-tenth of the total initially envisaged.

In sum, one could argue that the Sywnnerton Plan, the Yeoman and Peasant scheme, and the Million Acre Settlement Scheme were essentially intended to manage a stable transition to post-independence Kenya, and that in them lay Kenya's faulty start in dealing with its crisis of land reform.

The imperative to manage a stable transition predicated on a delicate balance between the interests of the landed gentry and the demands of the Kenyan electorate underpinned the programmes' objectives. The outcome was a failure.

\section{OVERALL IMPACT OF THE LAND REFORM PROGRAMMES}

Some of Kenya's most deeply rooted political conflicts have their roots in the weak foundations put in place to implement land reform. Since independence a minority of Kenyans had become wealthy, to the exclusion of those who had fought for independence.

The glaring disparities in the distribution of the fruits of freedom were widely accepted as an indirect outcome of the compromises inherent in the transition to independence and democracy (Leo 1984, p 157). Free-market purchase and government lending arrangements led to the emergence of large-scale farmers many of whom were members of Parliament, Cabinet ministers, senior civil servants and urban businessmen. (Leo 1981).

The nationalists, with the exception of the radical fringe opposed to the 
principle of compensation itself, came to see land settlement as a way of killing two birds with one stone: defusing rural unrest and promoting the interests of the African landed class. Other squatter settlement schemes were to be launched after independence, but more than half the settler lands were transferred by sale, almost intact, to wealthy Africans organised in partnerships or limited liability companies. Thus a new land policy based on class, instead of race was being established (Ogot \& Ochieng 1995, pp 64-65). By 1969 most of those who had been awarded land had defaulted on repayment of the loans, but, since resettlement was partly political, there were hardly any evictions (Leo 1981).

Another problem the land reform programme generated was racketeering. The 'willing-seller-willing-buyer'principle, as mediated through the market institution, concentrated the possession of property in the hands of a few politically powerful individuals. Other transactions, involving private and public land, were equally scandalous. Land racketeering articulated itself in two forms in the postindependence period - the transfer of public land to influential individuals and the exploitation of the landless by bogus land-buying companies (Cheche 1982, p 107). The complexity of these problems was partly the result of the tenure changes pioneered through the Swynnerton Plan and aimed at transforming customary land rights to individual freehold (Wanjala 1996, p 5; Ochieng 1995, p 33).

Political affiliations at this time reflected the extent to which ethnic-based considerations become a defining force in agrarian politics. Kanu's dominance enabled it to apportion land, disproportionately favouring its core support groups, especially the Kikuyu. This conflict over land persisted in post-independence politics and recurred alongside the ethnic violence that erupted during the transition to multiparty democracy in the 1990s (Ndegwa 1997).

At independence the disposition of all land was open to negotiation and by far the most contentious was scheduled land, which included developed whiteowned farms in the most fertile regions of the country. Land was a scarce resource for all groups, but particularly for the larger ethnic groups, whose population far outstripped their traditional lands and who were more likely to benefit from a freehold system.

For the Kikuyu from Central Province land scarcity had been aggravated by the land's appropriation by colonialists (Leo 1984). The minority groups, especially the traditionally pastoralist Kalenjin and Maasai communities, whose Rift Valley pastoral lands had been alienated for white settler farming, now faced the loss of these lands because of the introduction of a land market guaranteeing individual tenure, a system more suited to farming communities, especially the Kikuyu and Luo, who were better placed economically to purchase land and would dominate the central state that would administer the land redistribution programme (Ndegwa 1997). 
Various tribes were therefore grouped within regional boundaries. The Central region was designated for the Kikuyus, the Eastern region for the Kamba and the Meru, and the Maasai became part of Rift Valley region, which also included, among others, Kalenjin people and most large-scale farming and ranching areas. Areas of the highlands purchased for the settlement schemes were intended to accommodate specific ethnic groups. For example, the largest single settlement area was the strip of land between the Rift Valley and the western side of the Aberdare Mountains, which was set aside exclusively to serve Kikuyus.

The settlement programme, therefore, not only reaffirmed and hardened existing ethnic boundaries, but reintroduced ethnic uniformity in areas where mixing had already taken place spontaneously. In the eastern side of the Rift Valley, meanwhile, it was the non-Kikuyus who had been evicted to make way for Kikuyus (Leo 1984, p 111). Hence, the debate over how best to redistribute the land had a strong tribal bias which found its expression in the political debates that ensued and continue to inform current political conflicts and tension over land matters in contemporary Kenya.

By mid-1965 Kikuyu dominance in government and influence in policymaking was regularly mentioned both inside and outside Parliament. This emerged most clearly in the debates on land. In each successive budget debate in 1963, 1964 and 1965, members from all parts of the house challenged the government's land and settlement policies. Much of the criticism was directed at specific aspects of policy: the squatter problem and the future of labourers evicted from former European farms (Gertzel 1970, p 30). Tribal politics came to dominate the post-independence polity. In sum, the period between the early 1960s and the late 1970s was characterised by the negation of the promised democracy, constitutionalism, and the rule of law.

Opposition politics at this time was animated about land, which, in agrarian societies, forms a central pivot of socio-economic and political power. Land reform became a means through which the then political barons enriched themselves, their families, friends and sycophants. Kenyatta, for example, used land for patronage purposes and to build alliances, a pattern that continued and increased under his successor, President Daniel arap Moi (Kenya National Commission on Human Rights - KNHRC - and Kenya Land Alliance 2006, p 1). Moi consolidated his power through a combination of patronage and violence and land was used as an instrument of both, as seen in the land clashes that ensued in 1992.

In sum, the Kenyatta era was marked by struggles between Kanu, Kadu, and KPU in the Sixties and by the rivalries between the Luo and Kikuyu ethnic groups throughout the Seventies. A hallmark of this political schism was ethnic 
mobilisation for control of the independent state. In this regard, as will be shown in the next section, the only difference between the Kenyatta and Moi regimes was the intensity and degree of kleptocracy (Ajulu 1998, p 279).

\section{LAND REFORM UNDER MOI'S PRESIDENCY, 1978-2002}

After the demise of Kenyatta in August 1978 the then vice-president, Daniel arap Moi, took power. Although Moi was loyal to Kenyatta he was never accepted into his inner circle because he came from a small community, the Kalenjin (Sjögren \& Karlsson 2008). However, Moi was regarded by Kenyans as the right candidate to steer the country towards a more accommodating era, without ethnic dominance. This general perception of Moi was reinforced by the decisions and promises he made immediately after taking over the presidency. For example, in December 1978 he released 26 political detainees across the ethnic spectrum, most of whom had been in jail for years (Adar 2000, p 1).

In due course, however, Moi became more interested in neutralising those perceived to be against his leadership. Issues of corruption, ethnicity, and human rights became distant concerns. Instead, he began to centralise and personalise power (Adar 2000, p 1). He used Kanu to consolidate his power by intervening in nominations and replacing Kenyatta supporters with his own. He purged the provincial administration of disloyal elements, maintaining his grip on power. Over time, by re-organising national alliances and patronage networks to ensure patrimonial control, Kanu alienated many within the Kikuyu and Luo constituencies. Kikuyu and Luo grievances were now added to deep pastoralist and coastal grievances, particularly over irregular allocation of land, which proceeded apace under the Moi regime (Klopp 2001, p 477).

Most of Moi's public pronouncements on land matters exemplified his interest in land, which hinged on the need to protect popular interests (Kanyinga 2000, p 1). In retrospect, it is worth noting that Moi was one of the senior Kadu leaders who had vehemently advocated federalism (Majimbo) to protect the land and political rights of the smaller agro-pastoralist communities against the large ethnic groups.

His presidency naturally saw a reconstitution of former Kadu elites; their ideology on land soon occupying the centre stage of politics and the state itself. This raised expectations among minority tribes such as the Kalenjin, Maasai, Turkana, and Samburu (the Kamatusa tribes), who subsequently appropriated Moi's land ideology and fenced off their areas against other communities. This led to the closure of the frontiers in the Rift Valley, to which land-hungry groups had once migrated to acquire land. From as early as 1980, and in the process of constructing his own independent base of political support, Moi began to order 
the rapid individualisation of farms owned by land-buying groups (cooperatives, companies, and partnerships) and the registration of title for the individual shareholders. This move, too, was aimed at closing avenues of further entry into the heartland of the Rift Valley by land-hungry groups in general and the Kikuyu in particular (Kanyinga 2002, pp 4-6).

Moi's pronouncements on land were made alongside an increasing tendency to use it as a patronage resource. Political patronage evolved as the single most important medium of regulating access to public land. The government continued to give land as a reward for political patronage, with a view to establishing a stable political and economic class.

From the early 1990s, and in the face of increasing pressure for political liberalisation, the appropriation of government land by political elites went even faster as Moi struggled to retain loyalists, a rapidly disintegrating group (Kanyinga 2002 , p 5). In such a context public land, highly accessible and less encumbered by international conditions than private property, was an attractive patronage asset. In addition, administration officials, fearful that a change in government will end their privileged access to this public resource, have accelerated their accumulation of land and rents on land allocations.

However, privatisation of prominent public sites, including schools, bus stations, roads, parking lots, markets, police stations, forests, and public toilets, appeared to most Kenyans to be a particularly dramatic display of corruption (Klopp 2000, p 8).

As demands for political liberalisation increased in the early 1990s the appropriation of government land continued unabated in an attempt to contain the mounting pressure for political liberalisation. Invocations of historical injustices scripted into a political discourse about victimhood resonated particularly with ethnic groupings aligned to the Moi regime in the Rift Valley. Demand for territorial land claims, and a re-assertion of 'indigenous' notions of entitlement to belonging, spurred the spread of separatist and ethno-regional politics whose claim to territoriality was politically fuelled by Moi's struggling regime, intent on countering the spread of political liberalism.

Beyond, the land question Moi entrenched a new order whose fulcrum was his control over the party and the civil service (Southall 1998, p 102). The centralisation of power in the presidency and the intensification of kleptocracy were backed by the regime's increasing use of repression and intimidation (Southall 1998, p 102). As in Kenyatta's era, control of the state or proximity to those who had access to control became the main preoccupation of politics.

Access to control of the state was mediated through ethnic mobilisation (Ajulu 1998, p 279). To bolster his grip on power Moi also embarked, from the 1980s, on the gradual 'Kalenjinisation' of the public and private sectors. He began 
to 'de-Kikuyunise' the civil service and state-owned enterprises dominated by the Kikuyu ethnic group during Kenyatta's regime (Ajulu 1998, p 279). Despite the intensification of his authoritarian rule he was faced with increasing challenges and was confronted with the reality that the opposition was not about to wither and that pressure from donors was mounting (Klopp 2001, pp 16-17).

On 26 November 1991, at a consultative group meeting in Paris, donors collectively resolved to suspend aid - amounting to \$350-million - to Kenya until corruption had been curbed and the political system liberalised. Within weeks Moi had amended the Constitution to legalise the formation of opposition parties (Brown 2001, p 726). In 1992 many political parties were formed either to appease people or to attract them on the basis of their tribal affiliation. The introduction of multiparty politics brought ethnic politics to the fore as opposition parties quickly splintered into ethnic groupings. As a result, the first multiparty election held in 1992 was a contest that largely rotated around ethnic alignments (Bratton \& Kimenyi 2008).

In spite of forceful opposition Moi and Kanu managed to win the 1992 elections (Bratton \& Kimenyi 2008). Certain electoral rules were enacted with the sole purpose of favouring Moi. For example, Parliament amended the Constitution in August 1992 to require the winning presidential candidate to obtain at least 25 per cent of the popular vote in at least five of the country's eight provinces. Given the factionalisation of the opposition into clear ethno-regional bases of support, Moi appeared to be the only candidate able to meet this condition, even if he did not obtain the most votes nationally.

Kanu's victory represented an alliance of the minority ethnic groups - those from Coast, North Eastern, Eastern, Rift Valley, and Western provinces. Kanu was locked out of Central Province (Ajulu 1998, p 280). A similar pattern was noted in the 1997 election, when Kanu continued to draw support from the minority ethnic groupings (Southall 1999, p 98).

With the advent of multiparty politics the contest over land was used as a key political strategy to accentuate ethnic divisions/separatism. These struggles were attempts to reassert political power and legitimacy over who was historically entitled to land. Within the Rift Valley region the occupation by Kikuyu was seen as a-historical by the dominant tribes in this region, namely the Kalenjin, Maasai, Turkana and Samburu communities which had constituted the cornerstone of the ruling Kanu party since Moi assumed power in 1978.

Land clashes became an extension of the discourse between national and ethnic citizenship. The clashes began at Meteitei Farm, a co-operative farm located in the Nandi district in the Rift Valley and owned jointly by 310 Kalenjin and 280 non-Kalenjin farmers. On 29 October 1991 a dispute arose between these two groups. With the apparent collusion of local administrators and politicians 
the Kalenjin members of the co-operative claimed sole ownership of the land and expelled the non-Kalenjin (Kikuyu, Abaluhya, Kisii, and Luo) members. Those who resisted had their houses and property destroyed (Ndegwa 1997, pp $27-33)$.

A lexicon of difference was introduced during this period to denote the indifference towards outsiders felt by self-defined local people, the Kalenjin and Maasai. For instance, madoadoa and kwekwe (blemishes) referred to the 'contamination' of the ancestral lands of the Kalenjin and Maasai in the Rift Valley region by migrant ethnic groups, especially the Kikuyus. These new settlers were also referred to as Chui (leopard), a more insidious reference to the interlopers as land-grabbers (Ndegwa 1997, pp 27-33).

Clashes also occurred in parts of Coast Province (Likoni-Kwale) prior to and after the 1997 general elections, in areas that were known to be 'opposition zones'. As in the Rift Valley Province economic crises in the Coast Province centred on land. Over the years high-value land along the Kenyan coast had been purchased by well placed political elites from within and 'outside' the area, a fact that caused great resentment in ordinary people. In times of political crisis it has been possible to politicise the land issue and turn it into a campaign against the upcountry people, as evoked by the infamous separatist slogan wabara kwao! (upcountry people back to their original areas) (Ajulu 2001, p 211).

There is ample evidence to the effect that the 1992 and 1997 ethnic violence in the Rift Valley and Coast provinces was motivated by the government (NCCK 1992). Ruling party/state-orchestrated 'ethnic land clashes' threatened the cohesion of the country, as internecine civil wars were clandestinely promoted by politicians fearful of losing political office and anxious to protect their illegal gains (Gutto 1995, pp 38-39).

The primary means used to accentuate this rivalry among ethnic groups was to invoke narratives of historical injustices to which indigenous communities had been subjected with regard to territorial politics that centred on indigenous claims to land. The period between 1992 and 2001 saw government's continued efforts to divide the opposition, to deploy state assets (like land) to promote its own political agenda and to propagate ethnicity in order to remain in power.

Democratic consolidation was not tenable and the struggles over constitutional change continued throughout the post-1997 election period. In sum, Moi's regime, like that of his predecessor (Kenyatta), was marked by the continuation of a failed programme of land reform. It is evident that the continued sustenance of patrimonial control of the state was predicated on the ability to dispense political patronage, with land providing a strategic resource.

Part of the ease with which this was sustained was the fact that Kenya's post-independence state has systematically failed to formulate a new regime of 
land laws seeking to alter colonial land ordinances that have stubbornly persisted in the post-independence period. The lack of a constitutional framework to deal with land reform and the centralisation of the land administration system have led to the massive disinheritance of communities achieved through a sustained practice of patrimonial politics that oscillates through irregular land acquisition processes.

In the post-independence period the state adopted all the ordinances relating to the control of land and made them laws by which the post-colonial state was to regulate access to land. The Land Titles Ordinance of 1908 (which initially applied only to coastal areas because the Crown Lands Ordinance of 1902 covered the interior) became a law (Cap 285) under which a person could become the absolute owner of a piece of land and the immovable properties thereon by registering a claim or a right to the land. This ratified titles or claims registered under the 1908 Ordinance: registered claims became conclusive evidence of absolute ownership of land, thereby sealing the fate of the landless and squatters and intensifying the insecurity of their tenure.

The Crown Lands Ordinance of 1915, which became the Government Lands Act (Cap 280), vested in the president all the powers in relation to the leasing, granting and disposition of government land or former Crown Lands. The Act also retained the commissioner of lands (an appointee of the president) as the administrator of all public lands.

Like the ordinance the Act treated the state as the main landlord. Enormous powers of control over land that had been vested in the state through the governor were now transferred to the president to hold in trust. The concentration of power over land in the presidency and the central government reflected the general tendency towards the centralisation of political and economic activities (Kanyinga 2000, pp 52-53; KNHRC 2006, p 2).

Land reform as a precondition for increased rural economic production and development was undertaken to check and counteract the development of African politics rather than to give economic progress a positive and tangible political significance for rural Africans (Harbeson 1974, p 231). Nation-building since independence had shown little recognition of the objectives of African nationalism with respect to land.

\section{LAND REFORM UNDER KIBAKI'S PRESIDENCY: 2002-2007}

Kenya's third multiparty elections, in December 2002, revived hopes for the realisation of the much anticipated democratic transition. The elections were promising because, for the first time, the opposition parties were united. In October 2002 a coalition of opposition parties was formed under the National Rainbow 
Coalition (NARC). In the presidential election Moi's chosen successor, Uhuru Kenyatta, son of Jomo Kenyatta, candidate for Kanu, won only 31 per cent of the vote, compared to 63 per cent for Kibaki.

NARC won 125 of the 210 elected seats in the 224-member National Assembly, Kenya's unicameral Parliament, leaving Kanu with 64 seats and smaller parties in control of the remaining 21. Exercising their hard-won democratic rights Kenyans therefore overwhelmingly rejected the party that had ruled for 40 years. In doing so they showed contempt for the wishes of former President Moi and refused to be cowed by the powerful political lineage of the Kenyatta family.

In essence the NARC win heralded the dawn of a new political era (Anderson 2003, p 331) and the outright rejection of the dynasty Moi had attempted to introduce in lieu of ethnicity by his choice of Uhuru Kenyatta as his heir apparent. Many Kenyans nurtured strong hopes of a better democratic outcome that would bring to an end ethnic polarity, corruption, declining economic growth and infrastructural decay.

Unfortunately, as in the preceding years, no meaningful reforms were achieved. Under Kibaki's presidency the new ruling coalition promised to focus its efforts on generating economic growth, combating corruption, improving education, and rewriting the country's Constitution.

The period between 2003 and 2007 was characterised by extensive political animosity between pro-government and other political parties. The initial euphoria had been replaced by scepticism, mainly because of the alleged breach of a Memorandum of Understanding on power sharing among the constituent parties of the NARC coalition (Sjögren \& Karlsson 2008).

Plans to create the office of executive prime minister, a post intended for Raila Odinga, were abandoned, a move described by Raila's party, the Liberal Democratic Party (LDP), as not only a breach of the agreement in a narrow sense but a betrayal of a pact symbolising a new mode of politics based on broader ethno-regional representation and power sharing (Sjogren \& Karlsson 2008). Consequently, the LDP was gradually marginalised within the ruling coalition and informal political alliances grew in strength as 'pork-barrel politics' began to whittle down the collective strengths of the NARC coalition government (Anderson 2003, p 341). Like the preceding regimes Kibaki's first period in office was beset with controversy, particularly with regard to his inability to deal with corruption scandals and to exercise leadership in relation to graft.

Grievances over land issues found expression in a series of farm invasions by the Maasai in August 2004, further affirming the unresolved nature of Kenya's land question. More than 100 Maasai were arrested for invading white-owned farms in Laikipia District. Their chief grievances were the loss of land they had suffered through colonial instigated policies such as the Maasai treaties of 1904 
and 1911, which granted the settlers high-potential grazing land, giving the Maasai in exchange unproductive reserves and depriving them of up to $35 \%$ of their territory. Another grievance was the failure of the land titling programme aimed at pastoral communities (Rutten 1997).

The government's response to the crisis fuelled widespread controversy. Police were sent to arrest the invaders and incidents of human-rights violations and the use of excessive violence were reported in the news media. The then minister of Lands, Amos Kimunya, was cited as saying government did not recognise the agreements the Maasai community had signed with the British colonial authorities and blamed the demonstrations on economic saboteurs out to prevent the tourism sector, Kenya's leading foreign exchange earner, from recovering (Mathangani 2004). Government's stern response was shaped by its desire to maintain investor confidence in the wake of the invasions. The need for foreign exchange generated by tourism seems to have overridden genuine concerns about land hunger. However, the minister's position was challenged by his fellow ministers, ${ }^{4}$ who claimed that the Maasai had a very real grievance - their land had been leased for 99 years and, since this lease had now expired, they were entitled to reclaim it.

Maasai have lost huge chunks of land to non-Maasai through the land tenure system, a factor which has fed their resentment. The influx of agricultural groups and large-scale capitalist farmers following the freehold conversion to individual land rights held under statutory group title has aggravated their landlessness.

The resolution of the land issue was one of President Kibaki major promises during the 2002 election campaign (KHRC 2002). To that end, having won the election, Kibaki instituted the Ndung'u Commission to investigate patterns of corruption and unfair allocation of land and to propose remedies. However, the commission's report was deemed too controversial and the Kibaki government never implemented its recommendations (KHRC 2002).

The report noted that the practice of illegal allocations of land increased dramatically during the late 1980s and throughout the 1990s ... and land was ... granted for political reasons or [was] simply subject to "outright plunder" by "a few people at the great expense ... of the public"' (KHRC 2006). As resources for political patronage declined with the foreign-aid freeze of the 1980s the government turned increasingly to public lands and, as stocks of available public lands diminished, properties reserved for public purposes, such as roads and road reserves, public parks, playgrounds, game parks and reserves and forests were pilfered by state officials (Ndung'u Commission 2006).

4 Cabinet minister in the Office of the President, William ole Ntimama, a Maasai by origin, who has consistently championed the Maasai, was quoted by the East African Standard (26 August 2004) as castigating Land Affairs Minister Amos Kimunya for claiming that Maasai land was leased for 999 years and not 99 years, as historically reported. 
The commission also found that 'most illegal allocations of public land took place before or soon after the multiparty general elections of 1992, 1997 and 2002' and cited the families of presidents Jomo Kenyatta and Daniel arap Moi as some of the beneficiaries of the illegal allocation of public land. The annexures to the Ndung'u report contain the names of Mr Moi and five of his children, Mzee Kenyatta's widow, Mama Ngina, and scores of MPs, top civil servants, military officers, high court judges and former Cabinet ministers (Ndung'u Commission 2006). The commission's recommendations included an inventory of public land, a comprehensive land policy, and the establishment of a Land Titles Tribunal to review each case of suspected illegal or irregular allocation of land. Many of these ideas are contained in the draft land policy drawn up by the Ministry of Lands in 2006 (Ndung'u Commission 2006). However, neither the policy nor any of these important recommendations has been implemented because of political sensitivities. A good number of those implicated in the report held senior government positions in the then NARC government (2002-2007) and continue to do so in the coalition government established in February 2008.

Other reform initiatives during this period included the Draft National Land Policy (DNLP) of 2006, whose vision is to guide the country towards efficient, sustainable, and equitable use of land for prosperity and posterity (NDLP 2006). The object of the policy is to secure rights over land and provide for sustainable growth, investment, and the reduction of poverty in line with government's overall development objectives.

The draft policy acknowledges the ineffectiveness of the current Constitution in establishing an efficient, accountable, and equitable institutional framework for land ownership, administration, and management. These deficiencies have resulted in the inequitable distribution of land, particularly to women, children, minority groups, and persons with disabilities (NDLP 2006). However, since the NDLP underscores the need for a Constitution with broad principles on land, the policy proposals may not be realised without a new constitutional order.

The present Constitution, specifically s 75, declares the sanctity of title, regardless of how it was acquired. In addition, the Constitution provides for the protection of private property, including land. Attempts to change the status quo have so far failed, but unless there is a complete overhaul of the property provisions of the Constitution the land redistribution contemplated in the draft policy, will not materialise (KNLA 2006).

\section{THE 2007 ELECTORAL VIOLENCE AND THE POLITICS OF LAND}

The 2007 post-election crisis was the result of two sets of factors: long-term and immediate. The long-term factors are highlighted in the historical antecedents of 
the elections discussed in this paper, while the immediate factors are those that underscored the fallout within the ruling coalition, NARC, soon after it attained power in 2002.

One of the immediate factors is the unresolved issue of constitutional and legislative reforms, which involve the organisation and distribution of political power and resources. As stated above NARC had promised a new constitution within 100 days of its ascent to power. The deadline was postponed again and again, and certain Cabinet ministers from the inner circle of power obstructed and eventually walked out of the National Constitutional Conference, the so-called Bomas Talks. ${ }^{5}$ In place of the negotiated 'Bomas draft' the government presented a proposed constitution that, in many significant respects, ran counter to the Bomas draft. For example, the government version, also known as the 'Wako draft', ${ }^{6}$ recommended a presidential system with centralised powers (Sjögren \& Karlsson 2008).

The Bomas draft, on the other hand, in line with the election pledges made in 2002, proposed a more far-reaching power-sharing constitution, which, among other things, would reduce the power of the president by means of decentralisation and the parliamentary process. After protests and demonstrations the government's proposals were subjected to a referendum in October 2005, in which the government side (symbolised by the banana) lost to the opposition (symbolised by the orange).

Those Cabinet ministers, mainly from the LDP, who had supported a 'no' vote were subsequently sacked from government and created an alliance with the then opposition party, Kanu. The orange symbol was used to initiate the Orange Movement, which, a year later, was established formally as the Orange Democratic Movement-Kenya (ODM-Kenya) party (Sjögren \& Karlsson 2008).

In the two years between the 2005 referendum and the 2007 elections early campaigns revolved around the main protagonists, Mwai Kibaki and Raila Odinga. In terms of party affiliation Kibaki's government mutated first into NARC-Kenya in 2006, then, in September 2007, into the Party of National Unity (PNU), an alliance that, among other parties, incorporated Kanu, the former main opposition party. A split in the ODM between Kalonzo Musyoka and other top leaders resulted in Musyoka remaining in the ODM-K in August 2007 as Raila Odinga and other leaders defected to another 'orange party', the Orange

5 The conference took place at the Bomas of Kenya theatre facility, Nairobi, and was widely referred to simply as the Bomas Talks. The Bomas draft was initially formulated by the Constitution of Kenya Review Commission, appointed in 2000 to gauge the views of Kenyans about what they wished to see incorporated in their new constitution.

6 The Wako draft - the government version of the constitution - was named for Amos Wako, Chief Justice of Kenya, who was believed to be the key author of this alternative constitutional document. 
Democratic Movement (ODM), largely because of squabbles between Raila and Musyoka over presidential nominations prior to the elections (Sjögren \& Karlsson 2008).

The relevance of these party structures to the present discussion is their ideological and ethnic basis. The PNU attracted politicians and, by extension, people from the so-called 'Mount Kenya area', mainly the Kikuyu. The ODM, on the other hand, drew its support mainly from communities living in Western, Coast, Nyanza, Rift Valley, North-Eastern and Nairobi provinces. ODM-Kenya's support came mainly from Eastern Province, the home-turf of its presidential hopeful.

On 27 December 2007 the country held its fourth multiparty elections. An estimated 14,2-million Kenyans (82\% of eligible voters) were registered to vote, while 2547 parliamentary candidates were qualified to run in 210 constituencies. A total of 15331 candidates was approved to compete in the 2498 local wards. Nine candidates competed in the presidential election.

The elections were administered by the Electoral Commission of Kenya (ECK), a government body established by the Kenyan Constitution. The ECK has 22 commissioners, 19 of whom were appointed by President Kibaki. However, according to European Union and Kenyan observers the new commissioners were appointed without proper consultation with opposition parties, violating the Inter-Parliamentary Parties Group (IPPG) Agreement of 1997, which calls for consultation with opposition parties (Dayne 2008).

Several members of the ECK openly declared shortly after the election results were announced that they did not agree with the decision to declare Kibaki winner of the election and that there were serious problems with the vote count. The credibility of the election results was questionable given the discrepancies in the tallying of the results. For instance, in Molo, a small town in the Rift Valley, the results document reportedly reflected 50145 votes for President Kibaki, but the ECK chairman publicly announced that Kibaki had won 75261 votes (Dayne 2008).

In some constituencies the total number of votes counted exceeded the number of registered voters. In Maragua District, a Kibaki stronghold, the document received by the ECK showed voter turnout to be 115 per cent - this was later changed by the chairman of the ECK to 85 per cent (Dayne 2008). While the voting process was managed effectively what was disputed was the counting and tallying of the results, with the ECK accused of having doctored the results in favour of Kibaki.

The live broadcast of a press conference held by the leaders of the ODM to protest against what they regarded as the illegitimate and illegal swearing-in of Kibaki and to call for countrywide demonstrations was interrupted and an 
indefinite ban was slapped on future live broadcasts as well as on political rallies and demonstrations. The protests against Kibaki's swearing-in, which erupted spontaneously across the country, were met with police brutality, resulting in many civilians shot dead or wounded and an even greater number internally displaced (Dayne 2008).

Suspected Kibaki supporters, as well as some Kikuyu living outside Central Province, were targeted and attacked by communities that had voted for the opposition ODM. Their property and houses were looted and burnt, large numbers were chased away from their homes, many were injured, and some were killed. Correspondingly, many people from Western Kenya, Nyanza and Rift Valley were targeted in Central Province.

The violence claimed about 1500 lives, and resulted in approximately 350000 internally displaced people (IDP), who fled the violence-stricken areas. There have been various interpretations of the causes of the violence but a cursory glance at the voting patterns makes the reasons for the controversy over the results clear.

The 2007 election outcome contrasted starkly with those of 1997 and 2002. In 1997 President Moi won the election, with his party garnering the majority of seats in Parliament, a trend that was replicated by President Kibaki's win in 2002 under the aegis of NARC. Such anomalies confounded not only the political parties that disagreed with the election results but the wider public, who could not conceive how a presidential win is possible if the president's party does not have a majority of parliamentary seats. The resentment over the irregularities found expression in the violence that emerged among supporters of the two dominant parties.

Some observers have described the violence as a tribal conflict between the president's Kikuyu ethnic group and the Luo and Kalenjin ethnic groups. Indeed, Kikuyus were the principal targets in some areas, although the Luo and other ethnic groups were also targeted by the security forces and by Kikuyu groups. Kenyan civil society and human rights advocates argue that it is a mistake to describe the violence simply as a tribal conflict, since, for many Kenyans, the trigger was the rigged elections and fears of a return to dictatorship (Dayne 2008).

I, however, argue that the violence experienced in parts of the Rift Valley, for instance, was not spontaneous but well orchestrated according to deep-seated and historically ingrained territorial politics relating to land ownership. In the Rift Valley the election outcome in essence resuscitated old grievances between communities viewed as supporters of the regime, which had 'illegitimately' won the election.

A contest centred on the politics of land is not new in post-independence Kenya. The experience of the rivalry between Kanu and Kadu in the 1960s and 
1970s during Kenyatta's era, the violent clashes of the early 1990s in the Rift Valley and Coast provinces, and the December 2007 election violence (most pronounced in the Rift Valley), is that botched and politically manipulated land reform has defined the various modes of political expression and contestations Kenya has witnessed during these periods. In other words, political discord in Kenya cannot be understood effectively without understanding the interplay between the politics of land and the wider socio-economic and political system.

The two, I argue, are closely interwoven, and attempts to analyse election violence as an expression of a disenfranchised people with no history of ethnic rivalry and political competition are inadequate in explaining Kenya's political dynamics. Unfortunately, the ethnic factor in the country's politics has often been dismissed, overlooked, or considered secondary.

The Waki Commission, set up to investigate the underlying causes of the 2007-2008 post-election violence acknowledged the role played by ethnogeographic inequities. Constitutionally, individuals may own land in any place in Kenya and in law no part of the country belongs to a particular ethnic group. Nevertheless, this phenomenon is a de facto characteristic of many areas, particularly as many of the districts created since the 1990s have been ethnospecific, leading to the creation of ethnically homogenous effective 'native reserves'.

This, in turn, has created the notion of 'insiders' who are native to a place and 'outsiders' who have migrated there, a notion that has been tapped by aspiring politicians (Waki Report 2008, pp 30-33). This raises the question of the balance between group interests and the rights of individuals, as entrenched in the Constitution. The Waki Report further noted that failure to implement the recommendations of the Ndung' $u$ report into irregular land allocation increased a sense of frustration, as those implicated hold senior public office. Beyond expressing discontent with the failure of the government to deal decisively with irregular land allocation the report (2008, p 32) succinctly noted the role historic injustice coupled with political orchestration might have played in the violence:

In discussions of post-election violence, many Kalenjins argue that it is a product of longstanding anger over land distribution following independence. They argue that land was alienated by the colonial government and then unfairly parceled out to Kikuyus and other groups whom they view as outsiders. Many Kalenjins believe that issues relating to land were the reason for both the pre-electoral violence in the 1990s and the post election violence after the December 2007 elections. 
As violence escalated and in response to intense pressure from the international community the government accepted international mediation under the leadership of former United Nations Secretary-General Dr Kofi Annan, and the African Panel of Eminent Persons (Dayne 2008). Both the ODM and the PNU appointed representatives to the mediation team, which resolved to explore both short-term and long-term solutions to the crisis.

The long-term solutions centred on issues such as land reform; tackling poverty and inequity; addressing transparency, accountability and impunity; and supporting equal access to opportunity (United Nations 2008, p. 1). One of the major requirements recognised in the deliberations was the need to deal with the teething problem of land reform, constitutional reform, and a power-sharing arrangement, among other institutional reforms, to avert recurring conflicts in the country.

To allow for the implementation of the reforms, on 28 February 2008 a long-awaited political settlement was reached when Mwai Kibaki and Raila Odinga signed a power-sharing agreement. The settlement was contained in two documents, namely, the Agreement on the Principles of Coalition Government and the National Accord and Reconciliation Act 2008.

Perhaps what the grand coalition offers is an opportunity to constitutionally entrench wide-ranging land reforms that will ensure security of tenure irrespective of indigenous claims to designated areas, which are easily manipulated into ethnic feuds orchestrated as part of electoral malpractice aimed at winning elections. Hence, to make sense of the Kenyan political crisis, it is prudent to acknowledge the extent to which politicians use agrarian politics and narratives of historic injustices endured by communities as a way of circumventing political defeat.

In as much as Kenya's political deficiencies can be attributed to defective constitutional regimes, weak parliamentary systems, authoritarianism and electoral laws, the form that political rivalry, competition and patrimonial politics take reflects the botched attempts to deal with the question of land. In a country where close to 75 per cent of people are land-based, the sustainability of the grand coalition project is contingent on how the historic question of property relations is addressed.

The fact that some IDP are currently refusing to return to their farms in the Rift Valley for fear of reprisals, despite government assurances of their security, indicates the mammoth task of reconciliation and restitution the current government must undertake to avert future electoral violence. The current National Land Policy (NLP)(2008) provides an opportunity to deal with the structural, policy and political deficits that encumbered the attainment of a comprehensive programme of land reform. Despite the policy's noble objectives the mechanisms and expansive nature of the envisaged reforms are over ambitious 
and fail to acknowledge the experiences of countries that have attempted similar programmes.

\section{CAN THE NATIONAL LAND POLICY END KENYA'S LAND CRISIS? SOME CONCLUDING THOUGHTS}

The National Land Policy recognises the systemic shortcomings of Kenyan land reform: the continuity of a colonial land reform regime, centralisation of land administration and governance, a lack of accountability and transparency, the disinheritance of communities, the absence of a constitutional framework dealing with land reform.

The primary goal of the NLP is to attain security of land tenure - seen as a trigger for sustainable development, investment, and the reduction of poverty. However, the links between security of tenure, investment growth, poverty reduction, and sustainable development are not as simplistic as expressed in the NLP document, which draws heavily on observations made in the Ndung'u report, and previous drafts of land reform policy bodes. It seeks to identify the various challenges facing Kenya's land question and it offers a partial 'problem scenario' but it fails dismally to suggest practical steps. In essence it offers a framework for a set of policies and legislation that would allow the attainment of the following objectives:

- Increased access to land - equitable land ownership and use which is environmentally sustainable.

- Increased efficiency in the operation of the land market.

- Increased efficiency in the utilisation of land and land-based resources.

- The creation of dispute resolution mechanisms.

On the land tenure front the overall principles informing reform are equity and non-discrimination. In order to rationalise existing systems of private land ownership the NLP seeks to harmonise existing modes of statutory tenure under the Land Act; to ensure that the alienation of private rights to land takes into account all other legitimate rights held or claimed over the affected land, for example, the rights of spouses and children. With regard to leasehold it is proposed that the duration of leases does not exceed 99 years. In terms of the allocation of public land the policy proposes a ceiling limiting the amount of public land allocated to individuals or other entities and the harmonisation and elimination of multiple allocations.

On a more controversial note the policy seeks to bring to an end land tenure conversions introduced in 1955 by the Swynnerton Plan. Historically, the processes 
and procedures of land adjudication and consolidation were intended to eliminate customary tenure and replace it with statutory tenure-however, this process has been dismally slow. The process of tenure conversion has failed not only in Kenya but in other countries that have attempted to implement such a policy.

A major goal of land tenure conversion is to enhance people's land tenure rights with a view to delivering or securing security of tenure. In this regard land tenure reform is intended to facilitate the development and investment decisions of rural people, government institutions, and the private sector, which, in turn, will benefit rural livelihoods and facilitate infrastructure developments, service provision, and economic development (Sibanda 2003).

From a purely economic perspective the upgrade of land tenure rights is seen as an impetus to greater economic efficiency, growth and prosperity within the agricultural sector. Land tenure reform is therefore the basis of the restructuring or reorganisation of a proprietary regime and the institutional and administrative order that sustains such a proprietary system (Rutten 1997; Sibanda 2003).

The upgrade of land tenure rights is effected in two dominant ways - the issuing of title deeds subject to statutory law and the transfer of land to communities subject to traditional laws of succession, that is, customary law (Rutten 1997). Conceptually, tenure reform that seeks to replace communal tenure with freehold conversions typifies a 'replacement paradigm' approach.

The replacement paradigm advocated by the NLP is based on antiquated neo-classical economic theories which argue that traditional African land-tenure systems lead to an inefficient allocation of resources because property rights are not clearly defined, costs and rewards are not internalised, and contracts are not legal or enforceable (Rutten 1997). This theory holds that individualising land tenure increases the landholder's security of tenure, increases investment by improving tenure security, and will transfer land to those who are able to extract greater value from it as more productive users bid land away from less productive users.

The basic tenet underlying the legislative reform of land tenure is to protect the land rights of holders and ensure that the 'rule of law' is applied when these rights are removed or land is sequestered by the state. The empirical evidence of changes in land tenure and distribution of landholdings suggests that these policy ideals are rarely achieved (Moyo 2004). The implementation of the Swynnerton Plan is an example of this inherent shortcoming.

Another key pillar of the NLP relates to land issues requiring special intervention - historical injustices; pastoral land issues; coastal region land issues; the land rights of minority and marginalised groups, women, inhabitants of informal settlements, and children; land used for informal activities; and the impact of the HIV / AIDS pandemic on agricultural production and access to land rights. 
Among the mechanisms proposed to deal with these issues is the institution of a land redistribution programme aimed at providing the disadvantaged and the poor with access to land for residential and productive purposes. A key proposal is the need to institute land restitution measures to restore rights to those who have been unjustly deprived of them. The proposal is based on the recognition that the lack of access to land may be due to unfair governmental policies and laws. To this end, the government proposes to develop a legal and institutional framework for handling land restitution claims that have arisen since 1895, when Kenya became a colony.

In South Africa the land reform policy programme is made up of three pillars, namely: tenure reform, restitution, and redistribution. The legal framework that guides this programme is codified in the country's Constitution. Land restitution, as mandated by s 25(7) of the South African Constitution (1996) seeks to restore land to those who were forcibly removed from it, provided the dispossession can be proved and occurred no earlier than 19 June 1913. The restitution policy is guided by the principles of fairness and justice and, according to the 1997 Department of Land Affairs White Paper on Land Reform Policy, the process is driven by the demands of claimants who have been dispossessed.

A total of 79000 claims were lodged with the Commission on Restitution of Land Rights (CRLR) before the 1998 cut-off date (South Africa, Department of Land Affairs-DLA, 2004). According to the government nearly 90 per cent of the claims had been settled by 2006. The majority of the outstanding claims involve a large number of communities and are often marked by protracted struggles between communities and landowners.

In Namibia, in comparison, the restitution process was seen as too complex and adversarial to implement immediately after independence. One of the key deliberations at Namibia's land reform conference in 1991 was whether ancestral land should be returned or alternatives to redistribution sought. Political groups representing minority ethnic interests (Herero, Nama and Damara) argued for the restitution of their ancestral land.

Stakeholders realised it would be practically impossible to reconcile many of the competing claims to freehold land. The proposed restitution cases were viewed as too sensitive and conflicting and thus capable of derailing the conciliatory gestures that marked the transitional process (Melber 2002, p 2).

Based on South Africa's experience one can argue that rights-based reforms such as restitution programmes tend to disenfranchise claimant communities and often reflect the tensions inherent in attempting to attain rights restoration and sustainable development simultaneously. These tensions are emblematic in the ways in which adversarial relations have marked South Africa's restitution programme, and the limited livelihood gains this programme has generated. 
Conflicting and overlapping rights to land, claims of lineage, and the role of traditional leaders in accentuating these binaries should be taken into account in the creation of Kenya's restitution programme. The diversity of ethnic communities (42 in total) and the extent to which narratives of land dispossession have gained political resonance among key political actors as a conduit to building political alliances with their constituencies are bound to complicate the programme.

Beyond addressing the policy and legislative framework required to end Kenya's land crisis, the ecological and demographic dimension underpinning the success of the country's land reform deserves acknowledgment, as noted above. The scarcity of adequate arable land, coupled with Kenya's increasing population and its inability to diversify its economy, puts insurmountable pressure on land access as a primary pivot of livelihoods creation and sustenance amongst Kenya's burgeoning population.

In sum, the success of land reform and the alleviation of the structural ills associated with intermittent land-related violence are and will remain a daunting challenge in Kenya. Demographic pressures coupled with a harsh climate are ample reasons to evolve economic diversification strategies that transcend the country's preoccupation with land reforms as a panacea for its intermittent political ills.

\section{- REFERENCES}

Adar, K. 2000. 'The Internal and External Contexts of Human Rights Practice in Kenya: Daniel Arap Moi's Operational Code'. African Sociological Review $4(1)$.

\& I M Munyae. 2001. 'Human Rights Abuse in Kenya under Daniel Arap Moi 1978-2001'. African Studies Quarterly 5(1).

Ajulu, R. 1998. 'Kenya's Democracy Experiment: The 1997 Elections'. Review of African Political Economy 25(76).

2001. 'Kenya: One Step Forward, three Steps Back: the Succession Dilemma'. Review of African Political Economy 28 (88).

Anderson, D. 2003. 'Kenya's Elections 2002 - the dawning of a new era?' African Affairs 102(407).

Bratton, M \& M Kimenyi. 2008. Voting in Kenya: Putting Ethnicity in Perspective. Department of Economics Working Paper Series. Working Paper 2008-09. University of Connecticut. Available at: http://www.econ.uconn.edu/ working/2008-09.pdf

Bogonko, S. 1980. A Study in African National Movements. Nairobi: Kenya Literature Bureau. 
Brown, S. 2001. 'Authoritarian Leaders and Multiparty Elections in Africa: How Foreign Donors Help to Keep Kenya's Daniel Arap Moi in Power'. Third World Quarterly 22(5).

Caldwell, W. 1999. Issues and Responses: Land Use Planning in Eastern and Southern Africa. Harare: Weaver Press.

Cheche, K. 1982. Independent Kenya. Nairobi: Zed Press.

Daily Nation, The. 29 February 2008. Available at: www.nationmedia.com

Dayne, T. 2008. Kenya: The December 2007 Elections and the Challenges Ahead. Report for the Congress. Available at: www.fas.org/sgp/crs/row/RL34378.pdf

South Africa, Department of Land Affairs. 2004. Progress Report on the Implementation of the Comprehensive Agriculture Support Programme. Pretoria: Department of Land Affairs.

Draft National Land Policy, 2006. Nairobi: Government Printers.

East African Standard,The. 29 February 29 2008. Available at www.eastandard.net

Gertzel, C. 1970. The Politics of Independent Kenya 1963-1968. London: Heinemann Educational Books.

Gutto, S B O. 1995. Property and Land Reform Constitutional and Jurisprudential Perspectives. Durban: Butterworths.

Harbeson, J W. 1974. 'Land Reform and Nationalist Politics in Kenya'. The Journal of African History 15(1).

Heyer, J. 1981. Rural Development in Tropical Africa. London: Macmillan. ,J K Maitha \&W M Senga. 1976. Agricultural Development in Kenya: An Economic Assessment. Nairobi: Oxford University Press.

Hornby, D. 2000. 'Tenure Rights and Practices on a State-Owned Farm: The Community of Ekuthuleni'. I B Cousins (ed). At the Crossroads: Land and Agrarian Reform in South Africa into the 21st Century. Cape Town: Programme for Land and Agrarian Studies, University of the Western Cape.

Human Rights Watch. 2002. Kenya's Unfinished Democracy: A Human Rights Agenda for the New Government 14 (10)(A) Available at: www.hrw.org/ reports / 2002 / kenya2/

Hunt, D. 1984. The Impending Crisis in Kenya: The Case for Land Reform. Aldershot: Gower.

Kanyinga, K. 1998. Struggles of Access to Land. The Squatter Question in Coastal Kenya. Copenhagen: Center for Development Studies.

2000. Re-distribution from Above, The Politics of Land Rights and Squatting in Coastal Kenya. Uppsala: Nordiska Afrikainstitutet. . 2002. 'Kenya's Unfinished Business'. Human Rights Watch. Available at: www. hrw.org/reports / 2002/ kenya2/Kenya202-02.htm

Kariuki, S. 2004. 'Can Negotiated Land Reforms Deliver? The Case of Kenya, South Africa and Zimbabwe'. South African Journal of International Affairs 11(2). 
Kenya National Commission on Human Rights (KNCHR) and Kenya Land Alliance (KLA). 2006 ‘Unjust Enrichment: The making of Land-Grabbing Millionaires'. Living Large Series 2(1) Available at: www.hrw.org/en/node/62465/ section/6 Kenya National Land Alliance. 2006. 'The Draft National Land Policy: A Step Towards Land Reforms. Land Update'. A Newsletter of Kenya Land Alliance 3(3), July-September).

Kibwana, K. 1990. 'Land Tenure'. In W Ochieng (ed). Themes in Kenyan History. Nairobi: Heinemann.

Klopp, J. 2000. 'Pilfering the Public: The Problem of Land Grabbing in Contemporary Kenya'. Review of African Political Economy 47(1).

. 2001. " "Ethnic Clashes" and Winning Elections: The Case of Kenya's Electoral Despotism'. Canadian Journal of African Studies 35(3).

Leo, C. 1981. 'Who Benefited from the Million-Acre Scheme? Towards a Class Analysis of Kenya's Transition to Independence'. Canadian Journal of African Studies 15(2).

1984. Land and Class in Kenya. Toronto: University of Toronto Press.

Lonsdale, J. 2008. 'Kenya: ethnicity, tribe and state'. Open Democracy. Available at: opendemocracy.net

Mathangani, P. 2004. 'Tears of Fury as Land Protestors Clubbed, Arrested'. East African African Standard. Available at: www.eastandard.net/headlines/ news07070418.htm

Melber, H. 2002. 'Contested Territory: Land in Southern Africa: The Case of Namibia'. Journal of Namibia Scientific Society 50.

Miller, N. 1984. Kenya: The Quest for Prosperity. Boulder: Westview Press.

Migot-Adholla, S E, F Place \& W Oluoch-Kosura. 1994. 'Security of Tenure and Land Productivity in Kenya'. In J W Bruce \& S E Migot-Adholla (eds). Searching for Land Tenure Security in Africa. Iowa: Kendal/Hunt.

Migot-Adholla, S E, P Hazell, B Blarel \& F Place. 1991. 'Indigenous Land Rights Systems in Sub-Saharan Africa: a Constraint on Productivity?' The World Bank Economic Review 5(1).

Migot-Adholla, SE \& J W Bruce. 1994. 'Introduction: Are Indigenous African Tenure Systems Insecure?' In J W Bruce and S E Migot-Adholla (eds). Searching for Land Tenure Security in Africa. Iowa: Kendall/Hunt.

Ministry of Lands, 2006. Draft National Land Policy, National Formulation Process of Land Policy. Nairobi: Government of Kenya.

2008. National Land Policy, National Formulation Process of Land Policy. Nairobi: Government of Kenya.

Moyo, S. 2004. African Land Questions, the State and Agrarian Transition: Contradictions of Neoliberal Land Reforms. Available at: Ipp uerj.net/olped/documentos/1280. pdf 
Mugabe, J \& B D Ogolla. 1996. 'Land Tenure Systems and Natural Resources Management'. In J K Coetzee, J Graaff, F Hendricks \& G Wood (eds). Development, Theory, Policy and Practice. Cape Town: Oxford University Press.

National Council of Churches of Kenya (NCCK). 1993. 'The Role of Kenyan Churches in Democratization'. Paper presented at a conference on the Christian Churches and Africa's Democratisation, Leeds.

Ndegwa, S. 1997. 'Citizenship and Ethnicity: An Examination of Two Transition Moments in Kenya Politics'. American Political Science Review 91(3).

Ndung'u, P. 2006. 'Tackling Land Related Corruption in Kenya'. Available at: siteresources.worldbank.org/ RPDLPROGRAM / Resources / 4595961161903702549/S2_Ndungu.pdf

Njonjo Commission. 2002. Report of the Commission of Inquiry into the Land Law System of Kenya on Principles of a National Land Policy Framework Constitutional Position of Land and New Institutional Framework for Land Administration. Nairobi: Republic of Kenya

Ochieng, W. 1995. Themes in Kenyan History. Nairobi: Heinemann.

Ogot, B A \& W R Ochieng. 1995. Decolonisation and Independence in Kenya 1946-1993. Athens, Ohio: Ohio University Press.

Okoth-Ogendo, H W O. 1976. 'African Land Tenure Reform'. In J Heyer (ed). Agricultural Development in Kenya: An Economic Assessment. Oxford: Oxford University Press.

1998. The Perils of Land Tenure: The Case of Kenya. Tokyo: United Nations University Press.

Ondiege, P. 1996. 'Land Tenure and Soil Conservation'. In J K Coetzee, J Graaff, F Hendricks \& G Wood (eds). Development, Theory, Policy and Practice. Cape Town: Oxford University Press.

Republic of Kenya. 1963. The Constitution of the Republic of Kenya. Nairobi: Government Printer.

Republic of South Africa. 1996. Constitution of the Republic of South Africa.

Republic of South Africa, Department of Land Affairs. 2004. Commission on Land Restitution, Cumulative Statistics on Settled Restitution Claims. Pretoria: Government Printers.

Rutten, M. 1997. 'Land Reform in Africa: Lessons from Kenya'. In T Naerssen, M Rutten \& A Zoomers (eds). The Diversity of Development. Assen: Van Gorcum.

Sibanda, S. 2003. 'Comments on Land Reform, Income Inequality and Poverty Alleviation and Lessons from African Countries'. Bank of Namibia $5^{\text {th }}$ Annual Symposium Publication.

Sjögren, A\& P Karlsson. 'Kenyan politics 1963-2007: A background to the elections'. 
Available at www.nai.uu.se/articles/sjogren_and_karlsson/background$1 /$ index.xml

Sorrenson, M P K. 1967. Land Reform in the Kikuyu Country: A Study in Government Policy. Nairobi: Oxford University Press.

Southall R. 1998. 'Moi's Flawed Mandate: The Crisis Continues'. Review of African Political Economy 79(26).

2005. 'The Ndungu Report: Land and Graft in Kenya'. Review of African Political Economy 103.

1999. 'Re-forming the State? Kleptocracy \& the Political Transition in Kenya'. Review of African Political Economy 79 (26).

Sunday Standard 29 August 2004. 'Church Condemns Maasai Arrests'. Available at: www.eastandard.net/headlines/news29080402.htm

Tamarkin, M. 1978. 'The Roots of Political Stability in Kenya'. African Affairs 308(77).

United Nations. 2008. Humanitarian Update Vol 10. Office of the United Nations Humanitarian Coordinator in Kenya. Available at: http:/ / rescuekenya. wordpress.com/2008/05/27/ ocha-kenya-humanitarian-update-vol-19-0915-may-2008/

Waki, P. 2008. Report of the Commission of Inquiry into Post-Election Violence.

Wanjala, S. 1996. 'Recurrent Themes in Kenya's Land Reform Discourse since Independence'. Presented at the Southern and Eastern Regional Conference on Experiences, Perspectives and Strategies on Land Rights in Rural and Urban Settings, Johannesburg.

William, G \& E Francis. 1993. 'The Land Question'. Canadian Journal of African Studies 27. 


\section{REVIEW}

Kenya's Quest for Democracy: Taming the Leviathan

M Mutua

London: Lynne Rienner Publishing 2008

The book focuses on Kenya's journey towards achieving democratic ideals. These entail politics anchored in the ethos of accountability, adherence to the rule of law and the right of citizens to participate in periodic credible elections. The scope of the book extends from the colonial period to the 2007-2008 post-election violence triggered by the controversial declaration of Mwai Kibaki's reelection. Though the book covers African politics in general, Kenya provides the lens through which these issues are discussed.

In chapter one, which constitutes the introduction, Mutua argues cogently that constitutional reform is the sine quo non of reform, not only in Kenya but in many other African countries as well. In his words, 'the redemption of the post-colonial African state must start with the writing of a broadly legitimate national charter that creates a new compact between the state and its citizens' (p 2). He recounts some of the measures the Kibaki administration put in place in an attempt to clean up the body politic upon Kibaki succeeding Daniel arap Moi in 2002. However, he faults Kibaki's commitment to reform. Mutua criticises Kibaki for equating reformation of the state with forming numerous commissions, ostensibly to unearth improprieties under Moi's rule. He asserts that the fact that the Kibaki government was not genuine in its quest for reform resulted in the reform momentum fizzling out after he ensconced himself in power. Mutua bemoans the paucity of visionary leadership in most African countries. So grave is this leadership deficit, he believes, it is the single biggest threat to Africa's attempts to achieve prosperity, since, 'although many a society has failed with a visionary elite, not a single nation has ever prospered without one since the beginning of recorded history' (p 3).

Throughout the book the author places the burden of leading the state reformation process in Kenya on the shoulders of civil society. I do not, however, entirely agree with this opinion. Perhaps Mutua cannot resist the bias because he has close associations with this sector through the Kenya Human Rights Commission (KHRC).

In the wake of the 2002 general elections there was some kind of haemorrhage as most key figures in civil society took up positions in government. The alacrity with which they joined the political class that has so catastrophically betrayed Kenyans was astonishing. Civil society in Kenya has demonstrated that it is not immune to the ethnic factionalism and self-aggrandisement that have such an 
overwhelming influence on the country's politics. Notably Mutua cautions against a failure to seize the opportunity presented by the post-election violence in 2007-08 to reform the state. He analyses Kenya's socioeconomic and political malaise along a continuum beginning with the Jomo Kenyatta state in 1963, concluding that some of the excesses of the Kibaki presidency have their genesis in the immediate post-independence state that Kenyatta designed.

Chapter Two takes a bird's eye view of Africa's politics. According to Mutua the common denominator in Africa's upheavals in the post-colonial period is a struggle over the nature of the state. In most African countries various competing interests disagree about the way in which state power is organised, shared, and exercised. The author locates the pivot of the contest in the constitution. Unambiguously he asserts that, 'the crisis of the African state is an inability to create viable, legitimate, and democratic societies' (p11). The chapter engages with the theoretical postulations of different scholars on the issue of democracy.

Mutua believes African countries must strive to become constitutional states because such states are based on the concept of popular sovereignty. Moreover, in constitutional states the constitution provides for the state to be accountable to the people through a range of devices and techniques, the most critical of which is open, periodic, multiparty elections ( $p 110$ ). However, the author fails to mention African countries such as Mauritius and Botswana, which have tried to institutionalise governance, thus demonstrating that poor governance in Africa is an aberration, not the norm.

Mutua spends considerable time on the politics of ethnicity and how it impedes the realisation of a civic culture in Kenya. He argues that the politicisation of ethnicity, through which Kenyan politicians tended to mobilise support, was responsible for Kenya's stalled constitutional reform process. As a result of ethnicity the state reformation process was so bogged down in ethnic polarisation that politicians were more preoccupied with how the Constitution would help them further their political careers than about negotiating a set of rules and principles that would serve the country.

Mutua cites Tanzania to illustrate that there is nothing inevitable about ethnic politics. However, success in creating a nation state out of disparate ethnic communities requires the type of visionary and committed leadership embodied by Mwalimu Julius Nyerere, the first president of Tanzania. Mutua's analysis portrays ethnicity as an entirely repugnant phenomenon. He is oblivious to the fact that ethnicity can be used as a rallying point for grievance articulation by an ethnic group that genuinely feels excluded from mainstream politics. In this context, ethnicity can be used to pursue democratic ideals such as holding a government to account. 
The chapter recognises the importance of religion to Kenya's democratisation process. Certain religious organisations played an instrumental role in the fight against one-party dictatorship in Kenya, especially under Moi. However, some denominations supported one-party rule despite its excesses. But the intersection between religion and politics can be a tricky one, as evidenced during the constitutional conference in early 2002, where religion became a source of tension and animosity among the delegates. Among the contentious issues was the extent to which the Muslim kadhi courts should be enshrined in the Constitution. Mutua cautions that religion should not be mixed with politics because of its tendency to be conservative in relation to issues such as gender. Moreover, if religion is allowed to have free rein in politics, it could easily precipitate fundamentalism.

Overall, Mutua is optimistic about Africa's journey towards reform. However, he identifies the twin problems of illegitimacy of the African state and resistance to reform, which manifest themselves through repression, a disdain for civil society, the inability to perform the function of statehood and its proclivity for corruption as the most intractable and enduring of challenges to the reformation of the state.

Recognising the link between Africa and global politics the author argues that Africa's place in the international legal, political, and economic order is in need of revision.

Chapter three opens on a pessimistic note with the author judging the modern African state as an abysmal failure. He finds it hard to square the history of pain and suffering Africa has gone through with the mirth the continent invariably exudes. Dramatically, Mutua writes (p 33): 'Watching the plight of the continent, one cannot help but ask: Are Africans forever condemned by history, or is there hope? Once a part of the ubiquitous Third World, Africans now live in a lower substratum of that world, or even worse. Today they are segregated in something akin to Fourth World. Whatever the case, contemporary Africa is the forgotten continent, a sad and pathetic afterthought to most of the world.'

The author evokes an image of Africa as a desolate space left to its own devices. He conceives Africa not as part of the rest of the world but as an addendum, an appendage to the global community. Mutua identifies three epochs in Africa's history as being at the centre of the continent's pathologies: slavery, both European and Arabic, colonial conquest and the post-colonial African state. In his assessment colonialism has created the worst trauma on the continent, obliterating Africa's political institutions, borders, and culture.

So destructive was colonialism that it left in its wake what Mutua evocatively refers to as 'a phenomenon of self denial, an attempt to produce dark skinned Europeans, in essence dumb copies of the original' ( $p$ 34). In this context he 
portrays Africa as an ontological crisis that only excels in mimicry. Because of the colonial legacy Africa comes across as devoid of innovation and creativity. However, the author draws our attention to the fact that it was not so much colonialism per se that dislocated the continent as the violence and depth of the colonial enterprise. Of all former colonies in the world, Africa was exceptional in this regard.

The chapter shows that it has proven difficult to get rid of the tag of illegitimacy that hangs over the post-colonial African state because the citizens see it as a predator not a nurturer. The depression that pervades this chapter is tempered by Mwalimu Nyerere's exceptionalism. Nyerere showed that it is possible to inculcate into the citizenry a sense of nationhood through the invocation of certain ideals and norms that guide a people's lives. However, the caveat is that for nation-building efforts to bear fruit those ideals and norms must find expression in the lives of the leadership.

One of the poignant points made in the chapter is that in order to stave off the ontological crisis facing the post-colonial state there is need to indigenise the norms and values governing it, as opposed to those based on the European experience. The author avers that the African state has abdicated its responsibilities by its inability to protect its citizens and give economic meaning to their lives. The consequence of this dereliction of duty is a disillusioned and deeply cynical people across the continent.

Under the sub-heading 'Taming the Leviathan', Mutua attributes the crisis of the African state to its artificiality. The invention of the African state by colonialism, and the subsequent misapplication of the right to self-determination constitute a double whammy facing the continent. Coupled with other aggravating factors, the multinational character of the state is, in Mutua's words, 'its deforming Achilles' heel' (p 40).

The imposition of the one-party state in most African countries a few years into independence was intended to mitigate flaws characteristic of the African state. Mutua dismisses the one-party state, arguing that instead of fostering national unity, as its proponents argued it would, it failed catastrophically, so much so that in most cases it was 'a demented bandit, looter, and terrorist' ( $\mathrm{p} 40$ ). Tanzania is an exception.

The chapter engages with the question of devolution of governance structures through federalism, which a number of African countries experimented with as an antidote to the challenges of the post-colonial state. In Kenya an ethnic alliance advocated federalism for fear of being excluded from political leadership. The white minority settler class and sections of the Luhya, Kalenjin and several other ethnic groups feared the Kikuyu-Luo-Kamba alliance would deny them their share of the spoils of independence. 
The federalist experiment in Kenya came a cropper because the alliance substantially 'owned' the new post-colonial state, was numerically superior, and boasted the most prominent anti-colonial nationalist leaders. Though the experiment failed the federalist aspirations have never been extinguished.

Mutua attributes the failure of the constitution-writing project partly to these aspirations, pointing out that the federalist question was one of the most emotive issues at the National Constitutional Conference in 2003. Mutua contends that the problem of the 'ownership' of the Kenyan state remains one of the banes of its existence. In the 2003 constitutional talks 'devolution' replaced 'federalism' as the term of choice for the conflict between the centre and the regions, but despite the change in words emotions reached fever pitch because opponents of federalism viewed devolution as a camouflage for ethnic separatism.

The author takes a comparative approach to the federalist debate to show how controversial this form of governance was in countries where it has been tried - Uganda, Congo (formerly Zaire), Ethiopia, the Cameroons, and Nigeria. In all these cases the experiment either failed early on or created tensions among various ethnic groups within the state. Ethnicity partly accounted for the challenges federalism encountered on the continent.

Mutua asserts that because of the youth of the post-colonial state, the fragility of most economies, and the scarcity of other loci of power, elites treated the capture of power as a life-and-death matter. I am not sure how the author defines 'youth' in this context. Most African countries have been independent since the early 1960s (Ghana since 1957). How long does it take for an African nation to get it 'right'? The federalist contest tended to be bifurcated, as the Kenyan case demonstrated. Those in power, usually drawn largely from one ethnic group or coalition of groups, saw federalism as an attempt to weaken their grip on power, while those on the outside, vying for power, saw it as an equaliser, a tool to prevent domination and retain autonomy over their affairs.

The chapter concludes with an indictment of the post-colonial elite in Kenya for abandoning the liberal Constitution left by the colonialists. However the author observes that the Constitution was not 'homegrown', which is why some of the politicians of the time could not identify with it. Disregard for the Constitution under one-party rule in Kenya was seriously challenged during the immediate post-Cold War period, when there was a renewed clamour for liberal constitutions, which were seen as a solution to dictatorships and other excesses of the post-colonial state.

The author analyses some of the political changes in African countries since the beginning of the 1990s within the ambit of global politics. Since the end of the bipolar world a new global consensus has put political democracy at the centre of a cultural, social, and economic renaissance. Indispensable to this renewal is the 
reconstruction of the state into a liberal-democratic, pluralistic, market-oriented, open society, all of which hinge on the existence of a constitution. The chapter engages with various constitutional devices that could be used to address the challenges of the post-colonial African state and places the constitution at the centre of Africa's reconstruction.

Chapter four traces the history of the Kenyan state since the arrival of missionaries and colonialists. It covers the struggle against colonialism and focuses particularly on the political parties formed at the time. Mutua portrays Mau Mau as the foremost liberation movement in Kenya. He engages with the debate over whether Mau Mau was a liberation movement or an atavistic ethnic organisation. Taking a balanced approach Mutua observes that there was a class cleavage in the Mau Mau liberation movement which still has a bearing on Kenya's politics and concludes that Mau Mau was both a war of liberation and a civil war among the Kikuyu, pitting the educated and propertied against the landless.

The chapter attributes the perennial land conflict in most parts of Kenya to colonial dispossession and the failure of the Kenyatta government to redress the conflict by means of a land-reform policy. The author observes that 'Mungiki', a rag tag army of unemployed youth with violent inclinations, predominantly from the Kikuyu community, is an offshoot of the failure of the government to address colonial era class schisms. He is sceptical about whether the Kenyan state can gain substantial legitimacy as long as the volatile problem of land and atrocities and distortions of the colonial era are left unattended.

Mutua contrasts the rubric of the Constitution and the naked repression that characterised the colonial state. This contradiction is Kenya's enduring trademark in the sense that even multiparty general elections held every five years since 1992 have failed to rid the polity of the canker of illiberalism, corruption, and human rights violations.

The chapter shows that the constitutional review process in Kenya dates back to the period soon after independence. Although the independence Constitution had checks and balances, the Kenyatta government amended it liberally. The net effect was a dictatorship resulting from the centralisation of power in the presidency.

Mutua contends that the belief that an apparently well-drafted Constitution would work was a pipedream. Firstly, he argues that there was no way a wellmeaning constitution could be superimposed on a state that was oppressive, alien, and illegitimate. Secondly, the Constitution lacked contextual authenticity, since it was not home grown, having been prepared by Britons in the presence of few of Kenya's first-generation politicians.

Mutua blames the failure to institutionalise efficient governance in Kenya on the irresistible urge for self-preservation within the political elite. This class 
breached the sanctity of the Constitution with abandon throughout the postindependence period. The author points out that it was political convenience and survival that were the forces behind constitutional development and evolution in Kenya, rather than the challenges of a particular epoch.

The author casts aspersions on Kenyatta's liberation credentials, claiming that he warmed up to the colonialists just before independence and compromised on the land question, which was the impetus for the liberation struggle. The chapter also covers the ideological differences between Kenyatta and Oginga Odinga, the doyen of opposition politics in Kenya. Succinctly, Mutua accounts for the dishevelled post-colonial Kenyan state by blaming Kenyatta's authoritarianism, which transformed him from a liberation figure (in folklore though not fact) to a 'Big Man' in African politics who created 'a rubber stamp parliament stifled dissent and constructed a near monarchical personality cult' (pp 62-3).

The chapter indicates that Daniel arap Moi, who succeeded Kenyatta in 1978 following the latter's death, continued to muzzle alternative political views. He banned multipartyism and made the Kenya Africa National Union (Kanu), the ruling party, the centre of power. With the end of the Cold War domestic and international forces compelled Moi to accede to calls for a multiparty democracy.

In chapter five Mutua further bemoans the lack of tolerance of debate in Kenya, whose basis is the authoritarian colonial state. He asserts that in Kenya's history 'ruling elites have defined the state's interests so restrictively that quite often they even mistook their friends for foes' ( $p$ 75). Both Kenyatta and Moi used state apparatus to harass and detain both real and perceived opponents. Both rules were characterised by political assassinations, testimony to attempts to annihilate dissent.

Mutua blames Moi for frustrating constitutional reforms to such an extent that he proved to be the greatest obstacle to constitutional, legal, political and economic reform during his tenure. The use of ethnicity as a criterion for the occupation of key positions in government began during the Kenyatta state and continued throughout the Moi state. So pervasive was this neo-patrimonial brand of politics that opposition to Moi was equally informed by ethnicity. Government wished to defend the state; the opposition to capture it, but neither felt the need to effect institutional reforms. He avers that since Moi was associated with many malpractices opposition to his government came cheap: distaste for Moi and Kanu and loose and vacuous rhetoric supportive of democracy, the rule of law, and human rights were sufficient to identify opposition leaders as reformists.

The chapter brings out the recrudescence of ethnicity in Kenya's politics, as demonstrated by the crumbling of the once formidable opposition party the Forum for the Restoration of Democracy (FORD) in the run up to the 1992 multiparty 
elections. The author observes that although the party imploded because of personal and generational differences most analysts attributed the inability of the opposition to dislodge Moi to ethnic factionalism. Implicitly, Mutua doubts whether FORD would have governed any better had it won the elections. Although the party presented itself as an alternative to Kanu, the author argues that it had no social vision which could address the class character of the state. Against this backdrop it was highly unlikely that it would have fared any better than Kanu.

In this chapter Mutua analyses once again the role of civil society in democratisation in Kenya, mentioning several civil society organisations that played a significant role in bringing about political change. He believes these organisations must surmount inherent challenges in order to offer credible leadership. The chapter covers the half-hearted reforms Moi used to hoodwink the opposition into thinking he was committed to reform. Significantly, the chapter mentions the use of state sanctioned ethnic violence against communities sympathetic to the opposition in the early 1990s. The Rift Valley, Moi's home province, was the epicentre of the violence. Mutua delineates opposition struggles against the Moi regime since the 1992 general elections and the infighting within their ranks until they eventually succeeded in forming an alliance of convenience, the National Rainbow Coalition (NARC), which routed Kanu in 2002.

In chapter six Mutua argues that institutional and constitutional reforms are a prerequisite to the rebirth of governance. He shows that after Kenya's return to political pluralism a cross-section of Kenyans believed the opposition would easily bundle Kanu out of power since the party was synonymous with dictatorship. But through deft and ruthless use of the extensive apparatuses and resources of the state Moi soon recovered the initiative and won two consecutive presidential elections, in 1992 and 1997. The author shows that since Moi dictated both the pace and the content of the reforms until he left office in 2002 it was hard for the few reformists to effect any meaningful changes.

The chapter places constitutional reform at the centre of the country's transition from authoritarianism to a democratic dispensation. However, like the governing party a section of the opposition had an insular and self-serving interest in the reform agenda that resulted in the stillborn constitutional reforms. The author observes that the opposition which fought against a single-party monolith consisted of two groups whose visions for the country were at odds with each other. Whereas one advocated the legalisation of the opposition and the institutionalisation of minimum legal and constitutional reforms to level the playing field, with the ultimate aim of capturing state power, the other called for constitutional overhaul of the state and a basic reformulation of the purpose of political society. 
The first opposition grouping was not enthusiastic about comprehensive reforms, it hungered for raw political power. Thus the onus of leading state reform fell on the shoulders of civil society, notably bodies such as the KHRC and the Release Political Prisoners (RPP) organisation. It was ironic that even donors who had pressurised Moi to accept reforms prior to 1992 abandoned their interest in reform and focused on the elections. Mutua opines that the opposition was blinded by a false sense of hope that they would beat Moi and inherit the state, with all its awesome powers intact. Divided along ethno-regional lines they lost the 1992 general elections.

The Citizen Coalition for Constitutional Change, better known as the 4Cs and later the National Convention Executive Council (NCEC), are the other civil society organisations the author credits with spearheading the search for a new constitution. It was a process characterised by mass action and violence as civil society engaged with a recalcitrant regime determined to hold onto power at whatever cost.

The chapter underscores Moi's political acumen, especially after the 1992 general elections. In the run-up to the 1997 elections he realised that the clamour for reform threatened his hold on power. He astutely took back the reform initiative through the Inter-Parties Parliamentary Group (IPPG) talks, a conclave of Kanu and the parliamentary opposition. The move stole the thunder from the reform movement as most opposition members of Parliament abandoned the call for comprehensive constitutional reforms and acceded to minimum reforms which had no constitutional backing and were thus dependent for their implementation on Moi's goodwill.

In this chapter Mutua exposes the hypocrisy and lack of conviction of most politicians in Kenya. Instead of agitating for comprehensive reform the opposition was content to participate in elections organised under a constitutionally flawed system. The chapter details the treacherous road of the review process and the numerous hurdles and false starts it encountered, largely because of the opposition's hunger for power, which invariably rendered it susceptible to Moi's skullduggery.

Some of opposition figures who appeared committed to reform were halfhearted in their supposed commitment, many of them being indebted to the Kanu government, having benefited from its largesse. Moi astutely exploited deployed patronage to entrench himself in power, a move that partly explains why the route to constitutional reform has proved to be winding and convoluted.

In chapter seven the author attempts to place a finger on the pulse of the constitutional reform agenda in Kenya. Most Kenyans demand that the Constitution address a plethora of competing interests - class, religious, gender, ethnic, racial, political and social. The challenge is how to harmonise them before 
delivering on this all-important process, at the centre of which lies Kenya's renewal.

From the outset the author highlights the factors that impede attempts to reform the Kenyan state. He observes that since those in power use the state for self-aggrandisement they resist reform out of fear that should they lose power they will be economically and politically marginalised. This fear runs deep even within the opposition, as illustrated by the speed with which a section of the opposition abandoned reform rhetoric after ascending to power in 2002. The argument in this chapter is that Kenyans must strive for the institutionalisation of power rather than place their trust in politicians irrespective of their avowed ideological orientation.

The chapter covers the tensions and mutual suspicion between Moi and Raila Odinga. The latter was a seasoned oppositionist before entering a political relationship with Moi, which was loosely referred to as cooperation, an arrangement that was put in place immediately after the 1997 general elections in which both were presidential candidates. The birth of the Constitutional Review Commission of Kenya (CKRC) seemed to herald the advent of a new constitution but was caught up in the factional politics extant on Kenya's political landscape between supposed reformists and those who supported the existing constitution.

Throughout the process Moi appeared to hold all the aces, even after he acceded to a merger between the government committee for constitutional review and the civil society one. Most significantly Moi retained the option to change the rules and frustrated the work of the committee once he realised the CKRC was determined to make constitutional changes that threatened his hold on power. In addition he was able to influence the work of the commission since he appointed the chair and all the commissioners.

The commission was also beholden to the Parliamentary Select Committee (PSC), particularly to its chair, who had the power to propose amendments to the review law, to change the terms of service of the commission and to trim its powers. Ultimately the state succeeded in fending off attempts to create an independent, constitutionally protected review process but left a loophole through which it could exit from the process. Before the review was concluded Moi dissolved Parliament in readiness for the 2002 general elections, effectively scuttling the work of the commission because members of Parliament comprised one-third of all delegates to a scheduled National Constitutional Conference. Moi was suspicious of the radical reforms the commission suggested through a draft constitution aimed at dismantling the presidential behemoth.

Mutua even-handedly dismisses all the parties to the constitutional review process as narrow and self-centred in their approach. The Moi state, the opposition, 
civil society, and the religious fraternity did not have the national interest at heart, he contends.

Chapter eight dwells on the national constitutional conference process. Mutua points out that the reform process was flawed from the start because it did not begin with the type of constitutional conference used to rout entrenched regimes in countries like Mali, Congo, Zambia, and Benin. In Kenya, the incumbent regime controlled the review process. The author observes that the national constitutional conference failed because of the absence of sufficient momentum in the form of violence or another emergency that might have pressured the parties to come together to expedite the process. However, since other countries have held successful national conferences without the impetus of a crisis it is difficult to understand why the situation should have been different in Kenya.

The author takes the reader through the horsetrading that preceded the formation of NARC before the 2002 general elections and describes how, after wresting power from Kanu, the opposition was gripped by infighting and squabbling, an eloquent demonstration that Kenya's political landscape was devoid of national ideals beyond insular, self-serving and sectarian interests.

Mutua singles out a politician called Paul Muite as a champion of reform, but conveniently avoids stating that he was the very individual who, in 1982, had drafted the constitutional provision that made Kenya a de jure one-party state. The author argues that the fact that most of the political parties the country has had since independence have been ideologically anchorless explains the paucity of reform minded leaders within the NARC coalition. The only exceptions were the Kenya People's Union (KPU) and the Social Democratic Party (SDP). Thus, being united by the resolve to oust Kanu and without any alternative programme of action, NARC imploded because of factionalism as a result of a pre-election power-sharing agreement Kibaki trashed.

Mutua sums up the intrigues attendant on the constitutional reform process in the post-Moi political dispensation. The constitutional contest was tied to supremacy fights over control of the process. Rather than being a unifying factor the review process became a divisive element that polarised the country almost irreparably, as the 2005 plebiscite indicated.

In chapter nine Mutua zeroes in on some of the competing interests that emerged during the constitutional conference in Nairobi in 2002. There were heated debates on matters touching on gender mainstreaming, abortion, and the place of religion in the country's Constitution. Instructively he casts doubts on the viability of a government structure in which there is a powerful prime minister and a ceremonial president in a country fraught with ethnic divisions. According to him it would be disastrous if the two office bearers failed to agree and instead chose to involve themselves in zero-sum politics. 
The ascendancy of NARC to power resulted in heightened expectation among most Kenyans. However, factionalism, courtesy of the perennial paucity of ideology and sense of purpose among the political elite in Kenya, came to bear on the reform agenda in a profoundly negative way. The need to reorient Kenyan politics was abandoned in favour of self-aggrandisement. After the 2002 general elections members of Parliament awarded themselves hefty emoluments, which were compared to the earnings of their counterparts in developed economies.

The author observes that debate at the national constitutional conference was sterile because of a lack of depth among delegates which impeded their ability to grasp the issues. As a consequence they resorted to supporting a given position based on the identity of the individual taking that position as opposed to the merits and demerits of the issue. The chapter brings out the notion of the ineluctability of Raila Odinga, which some Kenyan politicians and analysts have long propagated.

Mutua states that delegates to the conference assumed that Odinga argued for a parliamentary system of governance because he could not be elected through a direct presidential election. This notion was shattered by the 2007 presidential elections, in which Odinga proved such a formidable challenge to Kibaki that his supporters were convinced he had been robbed of victory.

Mutua traces the genesis of Kenya's presidential system to Kenyatta's tenure and the fact that soon after independence he embarked on dismantling the Westminster system by doing away with the office of prime minister and incorporating the responsibilities hitherto undertaken by the occupier of that office into those of the president. In addition he dispensed with regional autonomy, thus reducing politics to a zero-sum affair.

The chapter covers the shenanigans that dogged the draft constitution under Kibaki in pretty much the same way as had Moi's intrigues. Kibaki's use of the courts to frustrate the constitutional review process marked him out as an obedient student of Moi. Recalcitrantly the Kibaki government presented Kenyans with a draft constitution with the executive structure still heavily tilted in favour of the president. Unsurprisingly it was resoundingly rejected by 57 per cent to 42 in the 2005 plebiscite. Though devolution has been touted as an antidote to Kenya's political woes Mutua argues convincingly that devolution without democratising both the centre and the periphery will not bring substantive reforms. In his words, 'it would multiply the number of dictatorships that Kenyans would be subjected to' (p 225).

The chapter places the plebiscite at the centre of the rupture that culminated in the post-election violence in 2007-08. The plebiscite, a dress rehearsal for the 2007 general elections, was essentially an ethnic census in the sense that Kenyans were mobilised to vote on the draft constitution along ethnic lines. Alliances formed, 
some of them based on personality cults. Kibaki's candidature was the rallying point for an oligarchic grouping fearful of an Odinga presidency. Politicians in the camps of both the opposition and the incumbent were implicated in malfeasance and other egregious acts during Moi's and Kibaki's tenures in office. Once again the reformation of Kenya's polity hit a dead end as politicians made political choices based on self-preservation.

The chapter identifies political parties as the foundation on which a democracy could be built. However, in the Kenyan context most political parties were ideologically bankrupt, lacked internal democracy, had no members and were in the vice-like grip of their leaders, who doubled as the principal financiers. Perhaps if the parties were constitutionally regulated the conduct of politics in the country might be less chaotic.

Chapter eleven deals with the tempestuous process of constitution-making under the Kibaki administration. Following in the footsteps of his predecessor Kibaki frustrated the review process because it threatened his untrammelled powers as president. The NARC's pledge to reform the state in the run-up to 2002 general elections was aimed at hoodwinking Kenyans who had suffered under one-party dictatorship. The author observes that the contestation over constitutional changes in Kenya does not fall within the saint and villain dichotomy. Few politicians at either end of the political spectrum can lay claim to reform credentials. Issues pertaining to the way statecraft must be approached depend on the individual's political fortunes and there is little commitment to national consciousness.

The 2005 plebiscite was the point at which polarisation in the country took an unprecedented form. However, blinded by Kibaki's need to secure power at all costs and his opponents' quest to wrest it from him, no one was concerned when Kenya began to hurtle steadily towards the abyss. The violence that erupted in the wake of the 2007 general elections was the result of zero-sum politics infested by a heavy dose of ethnicity.

Ethnic alliances that formed during the plebiscite replicated themselves during the 2007 elections, albeit with slight changes. In Mutua's opinion the violence gave politicians an opportunity to re-engineer the political and constitutional configuration of the country and to move away from the politics of self preservation that had been the norm since Kenya attained independence in 1963.

The elections shattered Kenya's image as a peaceful nation in a region ravaged by civil strife. The violence demonstrated compellingly that the Kenyan nation state was fragile and much would have to be done to infuse civic values into the body politic.

In chapter twelve Mutua summarises the issues raised in the book. He also 
points out what he believes needs to be done to make the country acceptable to all its citizens, irrespective of their linguistic or cultural background. He strongly recommends a new constitutional order, pointing out that its achievement calls for foresight and vision in the political class, for there is a close connection between the insight of leaders and the prosperity of a country. However, it appears that Kenya's political elite does not have the commitment to transform rhetoric into reality.

Matua accuses Kenyatta of erecting a monolithic presidentialism which visited upon the young nation inequities such as corruption, economic deprivation, mass atrocities and the denial of basic rights. His two successors followed the same route, to the extent that even after the reintroduction of multiparty politics in 1991, Matua believes, Moi left his position without internalising the limits of executive office.

Notably Mutua argues for devolution of power from the centre to the regions as a prerequisite for self-determination. He is quick, though, to state that this is not a panacea for the challenges facing Kenya, since almost all regions in the country are ethno-tribal unicultural enclaves designed along tribal lines. He also observes that the system of governance is potentially expensive in the sense that if not well designed it could result in an unnecessary proliferation of government departments, which will lead to lethargy, inertia, and inefficiency.

Mutua places the responsibility for leading reform on civil society and the churches, writing, 'Since the late 1980s, the mantle for reform leadership has unquestionably belonged to civil society. Within this sector, churches have been critical leaders in the struggle to open up the political process, guarantee fair play, and protect basic rights' ( $\mathrm{p} 275$ ). But as shown by the political events leading up to 2007 elections, these constituencies are not immune to the myopia, insularity, and sectarianism that hold sway among political parties in Kenya.

Though there are committed voices within civil society and the church, most of them unashamedly pursue politics injurious to the national fabric and hence are no better than the political practitioners. Some civil society figures who were co-opted into government after the 2002 general elections failed to stand up against the excesses of the Kibaki regime.

Mutua sums up in this chapter what he deems a combination of the factors that are troubling Kenya's body politic. In relation to the crushing poverty that afflicts most Kenyans he cites the global economic situation, particularly the debt burden, as one of the causes. He also discusses the Bretton Woods institutions, the World Trade Organisation, and their role in Africa's development.

He asserts that in a fractious multiethnic society like that in Kenya it would be dangerous to ignore pacts made among political leaders who derive their power from an ethnic base, as Kibaki did after the 2002 elections. He decries the 
squandering of the opportunity to rejig Kenya's political system presented by the 2002 opposition victory, comparing it to the situation soon after independence when the reform agenda was lost soon after NARC came onto power and instead power was colonised by a cabal of politicians drawn from the Mt Kenya region.

Matua observes that certain politically motivated actions such as assassination of prominent politicians since the Kenyatta era contributed to the entrenchment of despotism and the aversion of the powers-that-be to debate. This, he maintains, stifled the institutionalisation of democracy. Rather than engaging opponents the Kenyatta state resorted to eliminating them.

He also states that the banning of the Kenya People's Union in 1969 robbed the country of a chance to learn the practice of multiparty politics in a fragile multiparty democracy, since these formative years are crucial to determining how states will evolve in the future. He asserts that Kibaki's betrayal of the NARC dream irrrevocably altered the course of Kenya's politics and the effects manifested themselves in the 2007 general elections. Although those elections were coated with a thin veneer of ideology they were driven by ethnic fears and 'othering'.

The chapter ends on a sanguine note with the author observing that the African state can be tamed, as happened in Tanzania, for instance. Mutua's thesis is that the fact that Kenya almost joined the ignoble league of failed states in the wake of the 2007 general elections is testimony to the urgent need to institute reforms in that country.

One of the strengths of this book, one of the most recent analyses of Kenya's politics, is the even handed manner in which the author addresses most issues, even those as emotive as ethnicity. A lawyer by profession, Mutua has succeeded it making his work accessible and easy to read and to understand. I recommend the book for students of Kenyan politics as well as those who are interested in African politics in general.

Shilaho Westen Kwatemba PhD Candidate, Political Studies Department University of the Witwatersrand, Johannesburg 